\author{
SZEGEDI TUDOMÁNYEGYETEM \\ TERMÉSZETTUDOMÁNYI ÉS INFORMATIKAI KAR \\ MÚSZAKI INFORMATIKA TANSZÉK \\ Informatika Doktori Iskola
}

\title{
Véletlenszerü fluktuációk analízisén és hasznosításán alapuló mérési és titkosítási eljárások vizsgálata
}

Doktori értekezés

Készítette:

Vadai Gergely

Témavezető:

Dr. Gingl Zoltán

tanszékvezető egyetemi tanár

SZEGED

2018 



\section{Tartalomjegyzék}

1 Bevezetés .................................................................................................................. 3

2 Véletlen folyamatok kezelése és leírása …........................................................... 7

2.1 Valószínűségi változók jellemzése............................................................................... 7

2.1.1 Nevezetes eloszlástípusok .........................................................................11

2.1.2 Valószínűségi változók kapcsolatának leírása ...................................................14

2.2 Véletlen folyamatok leírása és osztályozása...............................................................18

2.2.1 Időbeli tulajdonságok leírása ……………........................................................19

2.2.2 Frekvenciatartománybeli leírás .......................................................................20

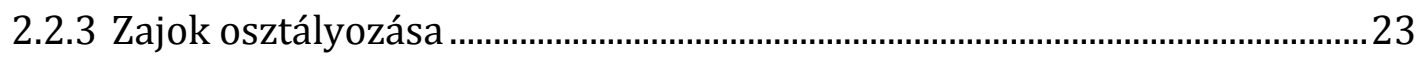

3 Zaj alapú abszolút biztonságos kommunikáció ...................................................25

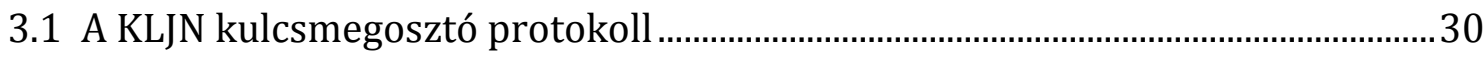

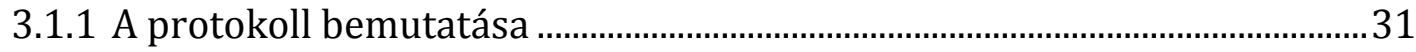

3.1.2 Támadási kísérletek, gyakorlati alkalmazások és további protokollok....34

3.1.3 A rendszer vizsgálata a matematikai statisztika eszközeivel .......................38

3.2 Az abszolút biztonságosság zajra vonatkozó feltételei..............................................38

3.2.1 A zajparaméterek hatásának numerikus vizsgálata .......................................41

3.2.2 A zajparaméterekre vonatkozó követelmények bizonyítása........................45

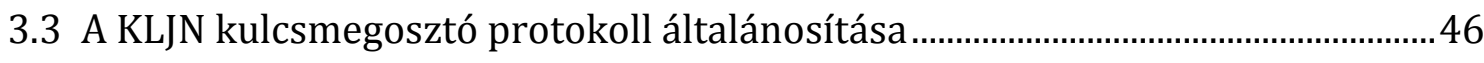

3.3.1 Az általánosított rendszer............................................................................... 47

3.3.2 Az abszolút biztonságosság zajra vonatkozó feltételei .................................48

3.3.3 Numerikus szimulációk …...............................................................................51

3.3.4 Az eredmények rövid összegzése és a rendszer előnyei ...............................55

3.4 Általánosított KLJN kulcsmegosztó rendszer gyakorlati alkalmazásokhoz .......57

3.4.1 A vezeték ellenállásának figyelembevétele......................................................58

3.4.2 Az abszolút biztonságosság zajra vonatkozó feltételei ..................................60

3.4.3 Speciális eset: az eredeti KLJN rendszer ........................................................63

3.4.4 A gyakorlati megvalósítás numerikus szimulációja ........................................65

3.4.5 Az eredmények rövid összegzése és a rendszer előnyei ................................69 
4 Versenykajak mozgásjeleinek fluktuációanalízise ......................................... 73

4.1 A mozgásjelek mérése és általános jellemzése ........................................................ 75

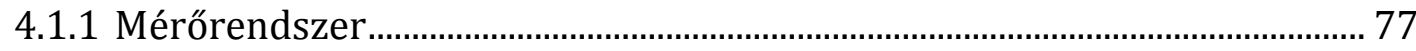

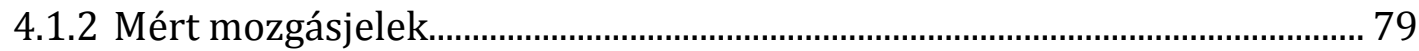

4.1.3 Evezést jellemző paraméterek meghatározása ................................................. 80

4.2 A mozgásjelek fluktuációanalízise ................................................................................ 84

4.2.1 A vizsgálat során használt adatsorok és osztályozásuk ................................ 87

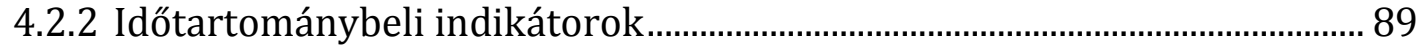

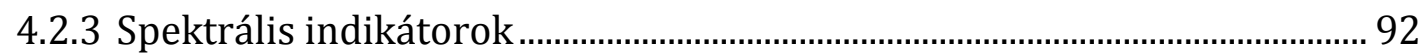

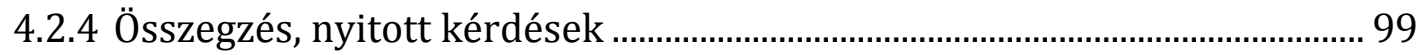

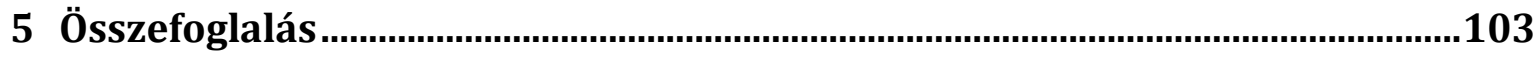

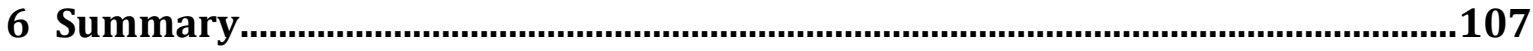

Köszönetnyilvánítás ................................................................................................111

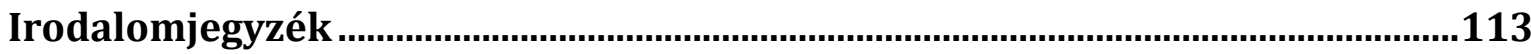

Az értekezés alapjául szolgáló közlemények....................................................................113

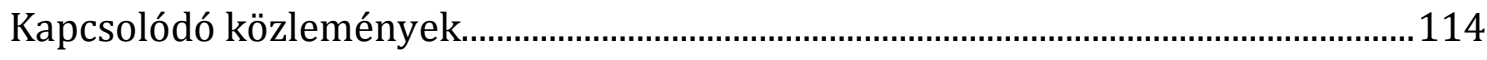

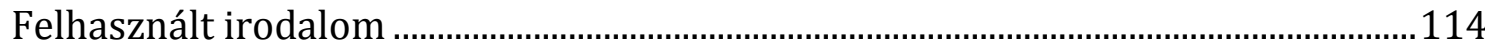




\section{Bevezetés}

A természettudományok elmúlt évszázadban történt paradigmaváltásai a természettörvények általános jellegéről alkotott képünkre is hatással voltak. Míg hagyományosan a jelenségek megjósolhatatlanságának okaként a rendszerek bonyolultságára és a determinisztikus összefüggéseket leíró egyenletek ismeretlen kezdőfeltételeire tekintettek, a kvantumfizika rávilágított, hogy bizonyos folyamatok csak a véletlenszerűség felhasználásával írhatóak le megfelelően.

A véletlenszerű jelek - továbbiakban „zajok” - így nem szükségszerűen hátráltató, kiküszöbölendő tényezők, hiszen információt is hordozhatnak a vizsgált rendszerekről, illetve konstruktív szerepet is kaphatnak; egyes rendszerek optimális működését éppen a zajok megfelelő alkalmazása teheti lehetővé. Az ilyen irányú vizsgálatok és alkalmazások számos tudományág, többek között a fizika, műszaki tudományok, informatika, orvostudomány, biológia, kémia, meteorológia vagy a közgazdaságtan különböző területein is igen hasznosnak bizonyultak. A zajkutatás, mint tudományterület ezen fluktuációk elméleti leírásával, illetve az említett területek vizsgálatai során előforduló zajok - sok esetben igen hasonló eszköztárral való - mérésével, modellezésével és analízisével foglalkozik.

Doktori tanulmányaim során a Zaj és nemlinearitás kutatócsoport tagjaként lehetőségem adódott számos különböző, multidiszciplináris kutatásba bekapcsolódni [1-13]. Értekezésemben ezek közül a zajok információforrásként illetve konstruktív szerepben való felhasználásának egy-egy példájául szolgáló alkalmazási területen elért eredményeimet mutatom be. Az ezeket összegző tézispontokat az [1-6] publikációk támasztják alá, míg a [7-9] publikációim ezekhez közvetve kapcsolódnak.

A zajok alkalmazására műszaki területeken számos példát említhetünk; egy rendszer átviteli függvényének mérésekor annak fehérzajjal történő gerjesztése vagy híradástechnikában a jel spektrális elfedése zaj megfelelő hozzákeverésével mind jól ismert gyakorlati módszerek [14]. A kvantálási hiba okozta információvesztés csökkentését megfelelő mértékű fehérzaj hozzáadásával, azaz a dithering módszerét a mechanikus számítógépek pontossága kapcsán való felfedezése óta a 
mikroelektronika, képfeldolgozás és távközlés területén is elterjedten alkalmazzák $[15,16]$. Az utóbbi évtizedekben tudományos berkekben jelentős figyelmet kapott a sztochasztikus rezonancia jelenségköre; bizonyos rendszerek esetén a - megfelelő mértékű és tulajdonságú - zaj jelenléte felerősíti annak determinisztikus gerjesztésre adott válaszát, néhány esetben lehetővé téve küszöbszint alatti jelek érzékelését is [17-19].

Ezen konstruktív szerepen túlmenően a véletlenszerű jelek speciális tulajdonságaik miatt bizonyos eljárások alapját is képezhetik. Ahogyan a kvantumszámítógépek és kvantumkriptográfia is bíztató alternatívát jelentenek a ma használt technológiával és titkosítási módszerekkel szemben, olyan, a véletlenszerűséget a klasszikus fizika keretei között kezelő, zajok használatán alapuló megoldások is megjelentek, mint a zaj alapú logika és a zaj alapú biztonságos kommunikáció [20, 21]. Ez utóbbi esetében a Kirchhoff-Law-Johnson-Noise (KLJN) protokoll bevezetése bő egy évtizede megmutatta, hogy létezhet a kvantumfizikai megközelítést nélkülöző abszolút biztonságos kulcscsere, az ehhez szükséges rendszer pedig jóval egyszerűbb, robosztus és költséghatékony. A protokoll alapja, hogy a két kommunikáló fél azonos ellenáspárral rendelkezik, melyből minden kulcsbit átvitelénél véletlenszerűen választ egyet, melyet a kommunikációs vezetékre kapcsol. Ha a két fél különböző módon választott ellenállást, a lehallgató által a vezetéken mérhető, az alkatrészek termikus zajának összegeként kialakuló feszültség és áramzaj alapján nem visszafejthető, melyik fél választotta a nagyobb értékű ellenállást. A protokoll feltörhetetlenségének bizonyítása a termodinamika második főtételén alapult.

Értekezésem első felében ezt a kommunikációs protokollt pusztán a matematikai statisztika eszközeivel vizsgálva először levezetem a rendszer abszolút biztonságosságának zajokra vonatkozó feltételeit, megadva a protokoll feltörhetetlenségének matematikai bizonyítását. Ezután a matematikai leírás adta lehetőségekkel élve általánosítom a protokollt, megengedve, hogy a két kommunikáló fél eltérő hardvert, azaz különböző értékű ellenálláspárokat alkalmazzon, amely eredmény, azon túl, hogy megkönnyíti a protokoll gyakorlati alkalmazását, az eredeti KLJN protokoll elméleti alapjainak újraértelmezését is eredményezte. Végezetül bemutatom a protokoll további kiterjesztését, melyben a korábban az ideálistól való eltérést jelentő, így információszivárgást okozó komponensek az abszolút biztonságos, ideális rendszer részeivé váltak, mely magától értetődően nagy előrelépést jelent a protokoll gyakorlati alkalmazásában.

$\mathrm{Az}$ értekezés második felében a fluktuációk információforrásként való felhasználásának egy új alkalmazási területét mutatom be. A zajok jelenléte hétköznapi életünkben is több esetben szolgáltat számunkra hasznos információt; elég az autó motorjának vagy a forrásban lévő víz akusztikus zajára gondolni. A műszaki területeken is számos ilyen alkalmazási példa található: az 
atomreaktorokban neutronfluxus ingadozásai a rendszer helyes működéséről, az integrált áramkörök és áramköri komponensek esetén a zajspektrum azok megbízhatóságáról tájékoztathat [22]. Hasonlóan, ellenállás mérésén alapuló gázszenzorok esetén a jel fluktuációjának teljesítménysűrűség-spektruma az ellenállás átlagértékéhez képest többletinformációt hordozhat, így a technika (Fluctuation Enhanced Sensing) segíthet a szenzorok szelektivitásának és pontosságának növelésében [23, 10-13].

A vizsgált jelek fontos osztályát képezik a periodikus folyamatok során mért mennyiségek, melyek véletlenszerű ingadozása ugyancsak informatív lehet számunkra. A változó csillagok periódusidejének ingadozása, az indukciós motorok mozgásának üteme, az emberi járás egyenletessége vagy a szívritmus variabilitása árulkodik a vizsgált rendszer helyes működéséről, fennálló hibáról vagy akár előre is jelezheti azt [24-28]. Számos sport esetén a megfelelő teljesítmény eléréséhez egy optimális mozdulatsor megfelelő ütemben történő ismétlése szükséges, mely mozgások inerciaszenzorok segítségével mára könnyen mérhetővé váltak.

Kajakos sportolók mozgásjeleinek vizsgálata során rámutattam, hogy az evezéseket leíró mennyiségek fluktuációja - mivel a mozgás egyenletessége egyértelmű kapcsolatban áll a sportolók teljesítményével - többletinformációt nyújt a mozgások értékelése során. A fluktuációanalízissel meghatározott indikátorok lehetőséget adnak az evezés technikai kivitelezésének értékelésére, így az edzők és sportolók munkáját könnyen értelmezhető mérőszámokkal segíthetjük. A periódusfluktuációk meghatározásához a legtöbb esetben elengedhetetlen az egyes periódusok detektálása, mely a mozgásjelek esetén sokszor igen nehézkes, erőforrásigényes és pontatlannak bizonyul. Ennek elkerülésére bevezettem egy spektrális, a jel-zaj viszonyon alapuló módszert, mely más periodikus jelek esetén is hasznosnak bizonyulhat.

A zajkutatás területén mind a folyamatok analitikus leírása és modellezése, mind a kísérleti vizsgálatok, mérési eredmények statisztikai elemzéséből levont következtetések igen nagy szerepet játszanak. Jól mutatják ezt az értekezés fó eredményei is: a zaj alapú titkosítási protokollok abszolút biztonságosságának elméleti bizonyítását és általánosítását matematikai módszerekkel, a statisztika és valószínűségelmélet eszköztárával végeztem, míg a kajakos sportolók mozgásjeleinek fluktuációiban mutatkozó trendek kimutatása a jelek megfelelő mérését, feldolgozását, időbeli és spektrális analízisét, majd a mérőszámok statisztikai kiértékelését igényelte. Az így tett új megállapításaim így sokkal inkább a fluktuációanalízis újszerű területen való hasznosságára és a bevezetett, jel-zaj viszonyon alapuló módszer hatékonyságára világítanak rá.

Értekezésemben először a véletlenszerü jelek leírásához szükséges matematikai eszköztárat vezetem be, a továbbiak megértéséhez szükséges ismeretekre szorítkozva. Ezután a 3. fejezetben a KLJN protokoll, a 4. fejezetben pedig a 
mozgásjelek fluktuációanalízisének területén elért eredményeimet mutatom be részletesen. Mivel ezen területek tudományos előzményei fontosak az eredmények megértéshez, de egymástól erősen elkülönülnek, így azokat a fő fejezetek elején ismertetem (3.1. és 4.1. fejezet), majd tudományos eredményeimet az 5. fejezetben felállított tézispontoknak megfelelően elkülönített alfejezetekben mutatom be, ahogyan az 1.1 táblázatban is látható.

\begin{tabular}{|c|c|c|c|c|c|c|c|}
\hline \multirow{3}{*}{$\begin{array}{l}\text { Tézis- } \\
\text { pont }\end{array}$} & \multirow{3}{*}{ Fejezet } & \multicolumn{6}{|c|}{ Közlemények } \\
\hline & & [1] & [2] & [3] & [4] & [5] & [6] \\
\hline & & $\begin{array}{c}\text { Folyóirat } \\
\text { Q3 } \\
I F=0,811\end{array}$ & $\begin{array}{c}\text { Folyóirat } \\
\text { Q1 } \\
I F=5,228\end{array}$ & $\begin{array}{c}\text { Folyóirat } \\
\text { Q1 } \\
I F=3,244\end{array}$ & $\begin{array}{l}\text { Konfe- } \\
\text { rencia }\end{array}$ & $\begin{array}{l}\text { Konfe- } \\
\text { rencia }\end{array}$ & $\begin{array}{c}\text { Folyóirat } \\
\text { Q1 } \\
I F=2,196\end{array}$ \\
\hline 1. & 3.2 . & - & & & & & \\
\hline 2. & 3.3. & & घ & & & & \\
\hline 3. & 3.4. & & & घ & - & & \\
\hline 4. & 4.2 . & & & & & - & घ \\
\hline
\end{tabular}

1.1. táblázat: Az értekezés új tudományos eredményeit összefoglaló tézispontok (lásd 5. fejezet), az azokat részletesen bemutató fejezetek és az alátámasztó publikációk kapcsolata, jelölve a folyóiratok esetében azok impakt faktorát (IF) és a Web of Science rangsora szerinti minősítését. 


\section{VÉLETLEN FOLYAMATOK KEZELÉSE ÉS LEÍRÁSA}

A zajok és fluktuációk vizsgálata során a véletlenszerűen ingadozó fizikai mennyiségeknek valószínűségi változókat feleltethetünk meg, így ezek kezelése során valószínűségszámítás és a statisztika eszköztáraira támaszkodhatunk [16, 29-33]. A következőkben ezen, a fluktuációk vizsgálatához szükséges matematikai eszközökből [16] az értekezés eredményeinek megértéséhez szükséges alapfogalmak és a vizsgálatok szempontjából lényeges ismeretek bemutatására szorítkozunk. Ezt követően a vizsgált folyamatok osztályozása és kísérleti vizsgálatuk során mérhető sokszor időben diszkrét - jelek idő- és frekvenciatartománybeli leírásához szükséges fogalmakat és módszereket mutatom be [16, 31].

\subsection{Valószínűségi változók jellemzése}

A véletlen jelenségek (a valószínűségelmélet terminológiája szerint kísérlet) lehetséges kimeneteleit elemi eseményeknek ( $\omega$ ) nevezzük, melyek összességének halmaza az eseménytér $(\Omega)$. E tér egy részhalmazát nevezzük eseménynek, mely akkor következik be, ha a véletlen kísérlet kimenetele olyan elemi esemény, mely eleme ezen eseménynek. Az eseményeket halmazelméleti műveletekkel kezelhetjük, továbbá az események $A$ halmazát ezen művelettekkel eseményalgebrának nevezzük.

$\mathrm{Az} \Omega$ eseménytéren értelmezett, A eseményhez rendelt $P(\mathrm{~A})$ függvényt valószínüségnek nevezzük, ha értéke bármely esemény esetén 0 és 1 közötti értéket vesz fel, a teljes eseménytér valószínűsége 1 és diszjunkt események együttes bekövetkezésének valószínűsége az egyedi események valószínűségének összege. $\mathrm{Az}$ $(\Omega, A, P)$ algebrai struktúrát Kolmogorov-féle valószínûségi mezőnek nevezzük, és a továbbiakban az ezen értelmezett fogalmakat és műveleteket tárgyaljuk. 


\section{Feltételes valószínúség és függetlenség}

Tekintsük A és B eseményeket, és utóbbiról feltételezzük, hogy valószínűsége nem nulla. A (2.1) egyenlet által definiált $P(\mathrm{~A} \mid \mathrm{B})$ valószínűséget az $\mathrm{A}$ esemény $\mathrm{B}$ eseményre vonatkoztatott feltételes valószínúségének nevezzük:

$$
P(A \mid B)=\frac{P(A B)}{P(B)},
$$

ahol $P(\mathrm{AB})$ annak valószínűsége, hogy $\mathrm{A}$ és $\mathrm{B}$ esemény is egyszerre bekövetkezik. Belátható, a valószínűségnél axiómaként bevezetett három reláció a feltételes valószínűségre is érvényes.

Az A és B eseményeket függetlennek nevezzük, ha teljesül az alábbi összefüggés:

$$
P(A B)=P(A) P(B),
$$

azaz a (2.1) egyenlet alapján

$$
P(A \mid B)=P(A) \text { és } P(B \mid A)=P(B) .
$$

A (2.2) definíció általánosítható, $n$ esemény egymástól független, ha azok együttes bekövetkezésének valószínűsége megegyezik az egyedi valószínűségek szorzatával.

\section{Valószínưségi változó, eloszlás- és sűrűségfüggvény}

Az $\omega$ elemi eseményekhez egy valós számot rendelhetünk, mely eseményalgebrán értelmezett $\xi: \Omega \rightarrow \mathbb{R}$ leképezést valószínüségi változónak nevezzük, ha igaz rá az alábbi összefüggés:

$$
\forall x \in \mathrm{R}:\{\omega \in \Omega: \xi(\omega)<\mathrm{x}\} \in A .
$$

A legtöbb esetben a valószínűségi változó értékei érdekesek számunkra, így az elemi esemény megjelölésétől a következőkben eltekintünk.

A $\xi$ valószínűségi változóról minden információt magában hordoz az $F(x)$ eloszlásfüggvény, mely megadja, hogy $\xi$ milyen valószínűséggel vesz fel egy adott $x$ alatti értékeket, továbbá segítségével kiszámíthatjuk hogy azok milyen valószínűséggel esnek egy [a,b) intervallumba:

$$
\begin{aligned}
& F(x)=P(\xi<x), \\
& P(a \leq \xi<b)=F(b)-F(a) .
\end{aligned}
$$

Értékkészletük alapján beszélhetünk diszkrét és folytonos valószínűségi változókról. Előbbi esetében a そáltal felvehető, legfeljebb megszámlálhatóan végtelen számú $x_{k}$ értékekhez a (2.7) definíció alapján társíthatunk valószínűségeket, melyek segítségével az eloszlásfüggvény a (2.8) egyenlet szerint áll elő. 


$$
\begin{aligned}
& p_{k}=P\left(\xi=x_{k}\right) \\
& F(x)=\sum_{x_{k}<x} P\left(\xi=x_{k}\right) .
\end{aligned}
$$

Folytonos esetben az eloszlásfüggvényt a $p(x)$ sürüségfüggvény segítségével a (2.9) összefüggés szerint adhatjuk meg, továbbá kiszámíthatjuk annak a valószínűségét, hogy $\xi$ értéke egy [a,b] intervallumba esik:

$$
\begin{aligned}
& F(x)=\int_{-\infty}^{x} p(t) d t \\
& P(a \leq \xi<b)=\int_{a}^{b} p(x) d x .
\end{aligned}
$$

Az előbbiek alapján a két esetben fennállnak az alábbi összefüggések:

$$
\begin{aligned}
& \sum_{k} p_{k}=1, \\
& \int_{-\infty}^{\infty} p(x) d x=1 .
\end{aligned}
$$

\section{Várható érték, szórás, momentumok}

A valószínűségi változók jellemzésekor kiemelt szerepet kap azok várható értéke és szórása. Előbbi az az érték, melyhez egy kísérlet kimeneteleinek számtani átlaga konvergál, vagy másképpen fogalmazva az a szint, mely körül a mért értékek ingadoznak. Ezen ingadozás mértékéről pedig a szórás ad számot.

$A z$ そ valószínűségi változó várható értékének definíciója diszkrét és folytonos esetben rendre a következő:

$$
\begin{aligned}
& E(\xi)=\sum_{k} x_{k} p_{k}, \\
& E(\xi)=\int_{-\infty}^{\infty} x p(x) d x,
\end{aligned}
$$

feltéve, hogy $\sum_{k} p_{k}\left|x_{k}\right|<\infty$ és $\int_{-\infty}^{\infty}|x| p(x) d x<\infty$.

Több valószínűségi változó összegére igaz a következő összefüggés:

$$
E\left(\xi_{1}+\xi_{2}+\cdots+\xi_{n}\right)=E\left(\xi_{1}\right)+E\left(\xi_{2}\right)+\cdots+E\left(\xi_{n}\right) .
$$


Az そ valószínűségi változó szórását az alábbi módon definiáljuk, amely alapján ennek négyzete, a szórásnégyzet vagy másnéven variancia a várható értéktől való eltérés négyzetének várható értéke:

$$
D(\xi)=\sqrt{E\left[(\xi-E(\xi))^{2}\right]} .
$$

A (2.15) és (2.16) egyenletek alapján belátható a következő összefüggés:

$$
D^{2}(\xi)=E\left(\xi^{2}\right)-E(\xi)^{2},
$$

mely alapján, ha $\xi$ várható értéke 0 , varianciája a négyzetének várható értékeként adódik. Ezt a véletlen fluktuációk kezelésekor igen gyakran kihasználjuk.

A várható értékre és szórásra az értekezés további fejezeteiben a valós mérési adatok statisztikai kiértékelése kapcsán széleskörben elterjedt $\mu$ és $\sigma$, illetve a variancia esetén a $\sigma^{2}$ jelölést alkalmazzuk.

Egy valószínűségi változó előbbi két jellemzőjének egyfajta általánosításával annak momentumaihoz jutunk, melyek hasznosak lehetnek egy eloszlás jellemzése során, vagy gyakorlati esetben éppen az eloszlás vagy sűrűségfüggvény ismeretének hiányában támaszkodatunk rájuk. Egy $\xi$ valószínűségi változó $\mu_{k}{ }_{k} \mathrm{k}$-adik momentumát és $\mu_{k} k$-adik centrális momentumát az alábbi módon definiáljuk:

$$
\begin{aligned}
& \mu_{k}^{\prime}=E\left(\xi^{k}\right), \\
& \mu_{k}=E\left[(\xi-E(\xi))^{k}\right] .
\end{aligned}
$$

A (2.16)-(2.19) egyenletek alapján azonnal látható, hogy a várható érték az első momentum, a variancia pedig a második centrális momentum.

A (2.13) és (2.14) egyenletekhez hasonlatosan a momentumok kifejezhetőek a diszkrét valószínűségek vagy folytonos esetben a sűrűségfüggvény segítségével:

$$
\begin{aligned}
& \text { diszkrét: } \mu_{k}^{\prime}=\sum_{i} x_{i}^{k} p_{i}, \text { folytonos: } \mu_{k}^{\prime}=\int_{-\infty}^{\infty} x^{k} p(x) d x, \\
& \text { diszkrét: } \mu_{k}=\sum_{i}\left(x_{i}-\mu\right)^{k} p_{i}, \text { folytonos: } \mu_{k}=\int_{-\infty}^{\infty}(x-\mu)^{k} p(x) d x,
\end{aligned}
$$

ahol $\mu=E(\xi)$.

\section{Valószínűségi változók függetlensége}

A $\xi_{1}, \xi_{2}, \ldots, \xi_{n}$ valószínűségi változókat függetlennek nevezzük, ha teljesül, hogy:

$$
\begin{aligned}
& P\left(a_{1} \leq \xi_{1} \leq b_{1}, a_{2} \leq \xi_{2} \leq b_{2}, \cdots a_{n} \leq \xi_{n} \leq b_{n}\right)= \\
& =P\left(a_{1} \leq \xi_{1} \leq b_{1}\right) P\left(a_{2} \leq \xi_{2} \leq b_{2}\right) \cdots P\left(a_{n} \leq \xi_{n} \leq b_{n}\right)
\end{aligned}
$$

feltéve, hogy $a_{1} \leq b_{1}, a_{2} \leq b_{2}, \ldots a_{n} \leq b_{n}$. 
Ha a valószínűségi változók függetlenek, várható értékük szorzatára és varianciájuk összegére teljesülnek az alábbi összefüggések is:

$$
\begin{aligned}
& E\left(\xi_{1} \cdot \xi_{2} \cdots \cdot \xi_{n}\right)=E\left(\xi_{1}\right) \cdot E\left(\xi_{2}\right) \cdots E\left(\xi_{n}\right) \\
& D^{2}\left(\xi_{1}+\xi_{2}+\cdots+\xi_{n}\right)=D^{2}\left(\xi_{1}\right)+D^{2}\left(\xi_{2}\right)+\cdots+D^{2}\left(\xi_{n}\right)
\end{aligned}
$$

A valószínűségi változók további együttes vizsgálatával a 2.1.2. fejezetben foglalkozunk részletesebben.

\subsubsection{Nevezetes eloszlástípusok}

A különböző diszciplinák esetén felmerülő gyakorlati alkalmazások során számos valószínűségeloszlás-típus kap kitüntetett szerepet, melyeket közös vonásaik, jellegzetes tulajdonságaik alapján valószínűségelméleti szempontok szerint is csoportosíthatjuk. Az alábbiakban a disszertációban bemutatott vizsgálatok során felhasznált eloszlástípusok, az egyszerűség kedvéért folytonos valószínűségi változók esetén keresztül kerülnek bemutatásra.

\section{Egyenletes eloszlás}

Diszkrét esetben magától értetődő, hogy kiemelt szerepet kap az az eset, amikor egy valószínűségi változó minden lehetséges értékét azonos valószínűséggel veheti fel, elég a kockadobásra vagy a véletlenszámgenerátorokra gondolnunk. Folytonos esetben egy そ valószínűségi változó egyenletes eloszlású az a $(a, b)$ intervallumon, ha a sűrűségfüggvénye:

$$
p(x)=\left\{\begin{array}{cl}
\frac{1}{b-a}, & \text { ha } a<x<b, \\
0, & \text { különben } .
\end{array}\right.
$$

Ekkor $\xi$ várható értéke és a varianciája:

$$
E(\xi)=\frac{a+b}{2}, D^{2}(\xi)=\frac{(b-a)^{2}}{12}
$$

$k$-ik momentuma és $k$-ik centrális momentuma:

$$
\mu_{k}^{\prime}=\frac{b^{k+1}-a^{k+1}}{(k+1)(b-a)}, \mu_{k}=\frac{(a-b)^{k}-(b-a)^{k}}{2^{k+1}(k+1)} .
$$

\section{Normális eloszlás}

Mind a valós, fizikai jelenségek kapcsán, mind valószínűségelméleti szempontból kiemelt jelentőséggel bír a normális eloszlás (más néven Gauss-eloszlás). Kitüntetett szerepét többek között azon speciális tulajdonságainak is köszönheti, melyeket az értekezés 3. fejezetében kihasználunk. 
A normális eloszlás sűrűségfüggvénye:

$$
p(x)=\frac{1}{\sigma \sqrt{2 \pi}} e^{-\frac{(x-\mu)^{2}}{2 \sigma^{2}}},
$$

ahol $\mu$ valós, $\sigma$ pozitív állandó, melyek éppen $\xi$ várható értékét és szórását adják meg:

$$
E(\xi)=\mu, D^{2}(\xi)=\sigma^{2} .
$$

A normális eloszlás kiemelt szerepének egyik oka, hogy a további momentumait, így magát az eloszlást is a várható érték és a szórás egyértelműen meghatározza. A $k$-ik momentumot az ún. Gauss-integrál segítségével, míg a $k$-ik centrális momentumot az alábbi formulával határozhatjuk meg:

$$
\mu_{k}=\left\{\begin{array}{c}
0, \text { ha } k \text { páratlan, } \\
\mu_{k}=\sigma^{k}(k-1) ! !, \text { ha } k \text { páros. }
\end{array}\right.
$$

Amennyiben $\xi_{1}, \xi_{2}, \ldots, \xi_{n}$ független, azonos eloszlású valószínűségi változók, melyek szórása jól meghatározott, a centrális határeloszlás tételének értelmében összegük sűrűségfüggvénye $n \rightarrow \infty$ esetén a normális eloszlás sűrűségfüggvényéhez tart, függetlenül a változók eredeti eloszlásától. Ennek fényében könnyen értelmezhető a normális eloszlás széleskörű előfordulása a természetben, mivel egy makroszkopikus véletlenszerű jelenséget sok esetben számos elemi esemény összessége határoz meg.

Az eloszlás további, számunkra kiemelten fontos, speciális tulajdonsága, hogy független normális eloszlású változók lineáris kombinációja is normális eloszlású, melynek várható értéke és varianciája megegyezik az egyes változók várható értékeinek, illetve varianciáinak azonos lineáris kombinációjával.

\section{Stabilis eloszlások}

A normális eloszlás ez utóbbi tulajdonságának általánosításával a stabilis eloszlások (más néven Lévy vagy $\alpha$-stabilis eloszlások) családjához jutunk [29, 33]. Az $\xi$ eloszlását stabilisnak nevezzük, ha az ugyanilyen eloszlású $\xi_{1}$ és $\xi_{2}$ független valószínűségi változók esetén tetszőleges $A, B$ számokhoz található olyan $C, D$ valós szám, amelyekre:

$$
A \cdot \xi_{1}+B \cdot \xi_{2}=C \cdot \xi+D .
$$

Független valószínűségi változók összegének eloszlásfüggvénye megadható a változók eloszlásfüggvényének konvolúciójával (jele: *), így az előbbi definíció alapján az $F(x)$ eloszlásfüggvény stabilis, ha adott $\mu_{1}, \mu_{2}$ valós és $\sigma_{1}, \sigma_{2}$ pozitív számokhoz található $\mu$ valós és $\sigma$ pozitív szám, melyek esetén a (2.32) összefüggés teljesül. 


$$
F\left(\frac{x-\mu_{1}}{\sigma_{1}}\right) * F\left(\frac{x-\mu_{2}}{\sigma_{2}}\right)=F\left(\frac{x-\mu}{\sigma}\right)
$$

A normális eloszlás esetén, az előbbiek alapján $\mu=\mu_{1}+\mu_{2}$ és $\sigma^{2}=\sigma_{1}^{2}+\sigma_{2}^{2}$.

A centrális határeloszlás tétele alapján belátható, hogy a normális eloszlás az egyetlen véges szórású stabilis eloszlás. Ugyanakkor léteznek további, nem véges szórású stabilis eloszlások, ilyen például a Cauchy-eloszlás, melynek sűrűségfüggvénye:

$$
p(x)=\frac{1}{\pi} \cdot \frac{1}{1+x^{2}} .
$$

Ez esetben $\mu=\mu_{1}+\mu_{2}$ és $\sigma=\sigma_{1}+\sigma_{2}$.

Mint láthatjuk, egy eloszlás stabilitásának vizsgálatához a valószínűségi változók lineáris kombinációjának eloszlását, azaz az eloszlásfüggvények konvolúcióját szükséges meghatároznunk. Egy $\xi$ valószínűségi változót azonban jellemezhetjük annak $\varphi(t)$ karakterisztikus függvényével, mely a $p(x)$ sürüségfüggvény Fouriertranszformáltja (amennyiben $F(x)$ abszolút folytonos), így a valószínűségi változók összegzését könnyen kezelhetjük a karakterisztikus függvényeik szorzásával.

A (2.32) egyenletnek eleget tevő eloszlásokat így általánosan azok karakterisztikus függvényével írjuk le:

$$
\varphi(t)=e^{i \gamma t-w^{\alpha}|t|^{\alpha}\left(1-i \beta \frac{t}{|t|} \Omega(t, \alpha)\right)},
$$

ahol i a képzetes egység, $0<\alpha \leq 2$ a stabilitási paraméter (más néven karakteriszitkus kitvetvó), $w \geq 0$ a skála-, $-1 \leq \beta \leq 1$ az aszimmetria- és $\gamma$ a helyparaméter, továbbá

$$
\Omega(t, \alpha)=\left\{\begin{array}{l}
\operatorname{tg} \frac{\pi \alpha}{2}, \text { ha } \alpha \neq 0, \\
\frac{2}{\pi} \log |t|, \text { ha } \alpha \neq 0 .
\end{array}\right.
$$

A disszertáció tárgyát képező véletlen fluktuációkra tekintettel a továbbiakban csak a 0 körüli szimmetrikus eloszlásokra szorítkozunk, ekkor $\beta=0$ és $\gamma=0$, az eloszlás karakterisztikus függvénye pedig a következő alakra egyszerűsödik:

$$
\varphi(t)=e^{-w^{\alpha}|t|^{\alpha}}
$$

Az $\alpha=2$ esetben a normális eloszlást, míg az $\alpha=1$ esetben a Cauchy-eloszlást kapjuk meg. Ezen speciális esetekkel ellentétben a stabilis eloszlások sűrűség- és eloszlásfüggvényeinek zárt alakja általában nem ismert, $\alpha<2$ esetben csak a $k<\alpha$ 
rendű abszolút momentumok léteznek, továbbá fontos kiemelni, hogy a szórás csak a normális eloszlás esetében véges.

\subsubsection{Valószínúségi változók kapcsolatának leírása}

Egy jelenség vagy kísérlet során sok esetben több mennyiséget, illetve azoknak megfeleltetett valószínűségi változót együttesen szeretnénk vizsgálni, azonban azok eddigiekben ismertetett jellemzői nem adnak felvilágosítást a köztük lévő kapcsolatról. A következőkben ezen együttes vizsgálat matematikai eszközei kerülnek bemutatásra, azon belül is az értekezés szempontjából fontos eset, két valószínűségi változó kapcsolatának leírása kerül a középpontba.

\section{Együttes eloszlás}

A $\xi_{1}, \xi_{2}, \ldots, \xi_{n}$ valószínűségi változókat egy $\underline{\xi}=\left(\xi_{1}, \xi_{2}, \ldots, \xi_{n}\right)$ valószínűségi vektorváltozóba foglalhatjuk össze. Megadható annak a $P(\underline{\xi} \in E)$ valószínúsége, hogy az $n$-dimenziós tér egy $E$ tartományába esik, e valószínűségek összességét a $\xi_{1}, \xi_{2}, \ldots$, $\xi_{n}$ valószínűségi változók együttes eloszlásának nevezzük.

A valószínűségi vektorváltozó a $\xi_{1}, \xi_{2}, \ldots, \xi_{n}$ változók értékkészlete alapján lehet diszkrét vagy folytonos, továbbá a (2.9) és (2.10) egyenletek $n$-dimenziós térre való kiterjesztésével definiálhatjuk a változók $H\left(x_{1}, x_{2}, \ldots x_{n}\right)$ együttes eloszlásfüggvényét és $h\left(x_{1}, x_{2}, \ldots, x_{\mathrm{n}}\right)$ együttes sürüségfüggvényét.

A $\xi_{1}, \xi_{2}, \ldots, \quad \xi_{n}$ valószínűségi változók (2.22) egyenlet szerint definiált függetlenségét megfogalmazhatjuk az együttes eloszlás- és sűrűségfüggvényekkel is:

$$
\begin{aligned}
& H\left(x_{1}, x_{2}, \ldots, x_{n}\right)=F\left(x_{1}\right) F\left(x_{2}\right) \ldots F\left(x_{n}\right), \\
& h\left(x_{1}, x_{2}, \ldots, x_{n}\right)=p\left(x_{1}\right) p\left(x_{2}\right) \ldots p\left(x_{n}\right),
\end{aligned}
$$

ahol $F\left(x_{i}\right)$ és $p\left(x_{i}\right)$ rendre $\xi_{i}$ eloszlás- és sűrűségfüggvénye, és $i=1,2, \ldots, n$.

A következőkben szorítkozzunk két, $\xi$ és $\eta$ valószínűségi változó kapcsolatának vizsgálatára. Ekkor $E$ egy síkbeli tartomány, a $(\xi, \eta)$ vektorváltozó véletlen $(x, y)$ értéke pedig egy síkbeli pontot határoz meg, melyhez egy valószínűséget társíthatunk. E valószínűségek összessége meghatározza $\xi$ és $\eta$ együttes eloszlását, mely diszkrét és folytonos esetben:

$$
\begin{aligned}
& P((\xi, \eta) \in E)=\sum_{\left(x_{i}, y_{k}\right) \in E} P\left(\xi=x_{i}, \eta=y_{k}\right), \text { ahol } i, k=1,2, \ldots \\
& P((\xi, \eta) \in E)=\iint_{E} h(x, y) d x d y
\end{aligned}
$$

ahol $h(x, y)$ a $\xi$ és $\eta$ valószínűségi változó együttes sűrűségfüggvénye. 
Az alábbi módon definiálhatjuk a változók $H(x, y)$ együttes eloszlásfüggvényét is, mely folytonos esetben kiszámítható az együttes sűrűségfüggvény segítségével:

$$
H(x, y)=P(\xi<x, \eta<y)=\int_{-\infty}^{y} \int_{-\infty}^{x} h(u, v) d u d v .
$$

Az együttes eloszlásfüggvény a valószínűségekre vonatkozó összes információt implicit módon tartalmazza.

\section{Feltételes várható érték, regresszió}

A gyakorlatban két mennyiség közötti kapcsolat vizsgálatákor sokszor az egyik (független) változó adott értéke esetén szeretnénk a másik (függő) változó értékét megbecsülni. Ez két véletlen folyamat esetén a mennyiségekhez rendelt valószínűségi változókkal és a (2.1) egyenlettel definiált feltételes valószínűség felhasználásval lehetséges. A $\eta$ valószínűségi változó $\xi=x$ feltétel melletti $G(y \mid x)$ feltételes eloszlásfüggvényét a következő módon definiáljuk:

$$
G(y \mid x)=\lim _{\Delta x \rightarrow 0} P(\eta<y \mid x \leq \xi<x+\Delta x) .
$$

A $\eta$ valószínűségi változó $\xi=x$ feltétel melletti $g(y \mid x)$ feltételes súrüségfüggvényét megadhatjuk a feltétel eloszlásfüggvény parciális deriváltjaként, vagy a két változó $h(x, y)$ együttes sűrűségfüggvénye segítségével:

$$
g(y \mid x)=\frac{\partial}{\partial y} G(y \mid x)=\frac{h(x, y)}{f(x)}
$$

ahol $f(x) \xi$ sűrűségfüggvénye.

$\xi$ és $\eta$ folytonos együttes eloszlása esetén $\eta$ valószínűségi változó $\xi=x$ eseményre vonatkozatott $E(\eta \mid \xi=x)$ feltételes várható értéke $\eta$ e feltétel melletti feltételes eloszlásának váható értéke:

$$
E(\eta \mid \xi=x)=\int_{-\infty}^{\infty} y g(y \mid x) d y
$$

Ha $x$-et $\xi$ lehetséges értékein végigfuttatjuk, az alábbi függvényhez jutunk, melyet $\eta \xi$-re vonatkozatott regressziójának nevezzük:

$$
y=E(\eta \mid \xi=x)
$$

Megjegyzendő, hogy e regressziós problémát olyan esetben is gyakran vizsgáljuk, amikor a független változó értéke determinisztikus, tehát az nem valószínűségi változó. 


\section{Kovarianca, korreláció, momentumok}

A (2.23) egyenlet alapján, ha 乡 és $\eta$ független valószínűségi változók, szorzatuk várható értéke megegyezik a várható értékeik szorzatával. Általános esetben a kettő nem egyezik meg, különbségükkel, a $c(\xi, \eta)$ kovarianciával tehát jellemezhetjük két változó függőségét:

$$
c(\xi, \eta)=E(\xi \eta)-E(\xi) E(\eta)=E[(\xi-E(\xi))(\eta-E(\eta))] .
$$

A két változó szorzatának $E(\xi \eta)$ várható értékét bizonyos területeken szokás korrelációnak nevezni (ahogy a 2.2.1. fejezetben is láthatjuk majd), mely 0 várható értékű valószínűségi változók esetében a kovarianciával egyenlő. Ez a valószínűségi változók által reprezentált mennyiségek szorzatának mértékegységével rendelkező mennyiség azonban nem keverendő össze a széleskörben használatos $\rho(\xi, \eta)$ (Pearson féle) korrelációs együtthatóval, mely dimenzió nélküli szám -1 és 1 közötti értéket vehet fel:

$$
\rho(\xi, \eta)=\frac{c(\xi, \eta)}{D(\xi) D(\eta)}=\frac{E[(\xi-E(\xi))(\eta-E(\eta))]}{D(\xi) D(\eta)} .
$$

$\mathrm{Az}$ egydimenziós esethez hasonlóan, a korreláció és kovariancia egyfajta általánosításával definiálhatjuk (folytonos esetre szorítkozva) $\xi$ és $\eta$ együttes eloszlásának $(m, n)$ rendú momentumait és centrális momentumait, melyek rendre:

$$
\begin{aligned}
& E\left(\xi^{m} \eta^{n}\right)=\int_{-\infty}^{\infty} \int_{-\infty}^{\infty} x^{m} y^{n} f(x, y) d x d y, \\
& E\left[(\xi-E(\xi))^{m}(\eta-E(\eta))^{n}\right]=\int_{-\infty}^{\infty} \int_{-\infty}^{\infty}\left(x-\mu_{x}\right)^{m}\left(y-\mu_{y}\right)^{n} f(x, y) d x d y,
\end{aligned}
$$

ahol $\mu_{x}=E(\xi)$ és $\mu_{y}=E(\eta)$.

A (2.48) és (2.49) egyenletekből látható, hogy az $m, n=1$ esetben a momentum a korrelációval, míg a centrális momentum a kovarianciával egyenlő.

Ahogyan látható a (2.46) és (2.47) egyenletekből, független változók esetén a kovariancia és a korrelációs koefficiens értéke 0 , azaz a változók korrelálatlanok. Azonban fontos megjegyezni, hogy a változók korrelálatlanságából még nem következik azok függetlensége, ez utóbbi csak a következőkben bemutatott normális együttes eloszlás esetén igaz.

\section{Kétváltozós normális eloszlás}

Ha $\xi$ és $\eta$ valószínűségi változók együttes eloszlása kétváltozós (másnéven kétdimenziós) normális eloszlás, együttes sűrűségfüggvényük a (2.50) egyenlet szerint áll elő, ahol $\mu_{x}=E(\xi), \mu_{y}=E(\eta), \sigma_{x}=D(\xi), \sigma_{y}=D(\eta)$ és $\rho$ a két változó korrelációs együtthatója. 


$$
h(x, y)=\frac{1}{2 \pi \sigma_{x} \sigma_{y} \sqrt{1-\rho^{2}}} e^{-\frac{1}{2\left(1-\rho^{2}\right)}\left[\frac{\left(x-\mu_{x}\right)^{2}}{\sigma_{x}{ }^{2}}-2 \rho \frac{\left(x-\mu_{x}\right)\left(y-\mu_{y}\right)}{\sigma_{x} \sigma_{y}}+\frac{\left(y-\mu_{y}\right)^{2}}{\sigma_{y}{ }^{2}}\right]}
$$

Az összefüggésből látható, hogy amennyiben $\rho=0$, az együttes sűrűségfüggvény a そ és $\eta$ normális eloszlású valószínűségi változók szorzataként áll elő, azaz a (2.38) összefüggés alapján a két változó független. Az együttes sűrűségfüggvény által meghatározott felület $x, y$ síkkal párhuzamos metszetei olyan ellipszisek, melyek tengelyi a főtengelyekkel párhuzamosak. Függő változók esetén a szintvonalak által meghatározott ellipszisek tengelyei nem párhuzamosak a főtengellyel, e geometrai kapcsolatot alább, a lineáris regresszióval jellemezzük.

Mint láttuk, kétváltozós normális eloszlás esetén a változók korrelálatlanságából következik azok függetlensége is, mely megállapítás magasabb dimenziószámra is általánosítható. Ha $\xi_{1}, \xi_{2}, \ldots, \xi_{n}$ valószínűségi változók együttes eloszlása normális, akkor ezek külön-külön mind normális eloszlásúak, továbbá, ha páronként korrelálatlanok, akkor függetlenek is.

\section{Két valószínű́ségi változó kapcsolatának statisztikai jellemzése}

A (2.45) egyenlettel megadott regressziós görbe meghatározásához, és általánosabban két valószínűségi változó együttes eloszlásának teljeskörű jellemzéséhez az együttes sűrűségfüggvény ismerete szükséges, mely sok esetben nem teljesül. Gyakorlati esetben két mennyiség - melyeknek a $\xi$ és $\eta$ valószínűségi változókat feleltetjük meg - véges számú mért értéke alapján azok eloszlásának, illetve együttes eloszlásának néhány momentumát ismerjük. E jellemzőket a mérési eredmények statisztikai vizsgálatával, illetve a két mennyiség mért értékeinek egymás függvényében való ábrázolásával kapott szórásdiagram jellemzésével határozhatjuk meg.

Az elméleti regressziós görbét közelíthetjük az alábbi módon definiált lineáris regresszióval:

$$
y=\mu_{y}+b\left(x-\mu_{x}\right)=\mu_{y}+\rho \frac{\sigma_{y}}{\sigma_{x}}\left(x-\mu_{x}\right),
$$

ahol $\mu_{x}=E(\xi), \mu_{y}=E(\eta), \sigma_{x}=D(\xi), \sigma_{y}=D(\eta), \rho$ a korrelációs együttható és $b=\rho \frac{\sigma_{y}}{\sigma_{y}}$ a regressziós együttható.

Két valószínűségi változó kapcsolatát így vizsgálhatjuk az együttes eloszlásuk lineáris regressziójával, azaz a szórásdiagramra történő egyenesillesztéssel. E regressziós egyenes áthalad az eloszlás $\left(\mu_{x}, \mu_{y}\right)$ súlypontján és iránytangense $b$.

A fenti kapcsolat a korrelációs és lineáris regressziós együtthatók között tetszőleges eloszlások esetén fent áll (azaz a lineáris illesztés esetén ekkor lesz az átlagos négyzetes hiba a legkisebb), azonban fontos megjegyezni, hogy normális 
együttes eloszlás esetében ez nem csupán becslés, a (2.43), (2.45) és (2.50) egyenleteket felhasználva belátható, hogy ez esetben a lineáris regresszió megegyezik a (2.45) egyenlettel definiált elméleti regresszióval.

Másképpen fogalmazva normális együttes eloszlás esetén $\eta \xi$-re vonatkoztatott regressziója egy egyenes, azaz a függvénykapcsolat $\xi$ és $\eta$ között lineáris, továbbá a függőséget a korreláció elméleti szempontból tökéletesen megadja. Ez utóbbi megállapítás jól mutatja a normális együttes eloszlás kitüntetett szerepét: azt a várható értéke, szórása és a korreláció egyértelműen meghatározza. Ez jól látható az Isserlis formula kapcsán is [34], mely segítségével $\xi$ és $\eta$ együttes eloszlásának tetszőleges momentuma kifejezhető azok varianciája és kovarianciája segítségével. A normális eloszlás e kedvező tulajdonságait kihasználjuk az értekezés 3. fejezetében.

Valós mérési eredmények kiértékelésekor a függő és független változó közötti kapcsolatot jellemezhetjük a regressziós egyenesre való illeszkedés mértékével. Ezt számos területen az $R^{2}$ determinációs együttható segítségével szokás megadni, mely a $\rho$ korrelációs együttható négyzete.

\section{Független változók lineáris kombinációinak függetlensége}

Ugyancsak fontos a következőkben bemutatott eredmények szempontjából Lukacs és King független valószínűségi változók lineáris kombinációira vonatkozó tétele [35]: $\xi_{1}, \xi_{2}, \ldots, \xi_{n}$ független valószínűségi változók (2.52) összefüggés által megadott $Y_{\mathrm{A}}$ és $Y_{\mathrm{B}}$ lineáris kombinációi akkor és csak akkor függetlenek, ha minden $\xi_{k}$ változó normális eloszlású és a (2.53) összefüggés teljesül.

$$
\begin{aligned}
& Y_{A}=\sum_{k=1}^{n} A_{k} \cdot \xi_{k} \text { és } Y_{B}=\sum_{k=1}^{n} B_{k} \cdot \xi_{k}, \\
& \sum_{k=1}^{n} A_{k} \cdot B_{k} \cdot \sigma_{k}^{2}=0,
\end{aligned}
$$

ahol $\sigma_{k}=D\left(\xi_{k}\right)$.

\subsection{Véletlen folyamatok leírása és osztályozása}

$\mathrm{Az}$ eddigiekben a véletlenszerűen ingadozó fizikai mennyiségeknek egy valószínűségi változót feleltettünk meg. A valós fizikai folyamatok esetében azonban nem csak a mennyiségek felvett értékei, hanem azok statiszitkai tulajdonságai is változhatnak az idővel. Ezt a korábbiakban már bevezetett valószínűségi vektorváltozók felhasználásával írhatjuk le, általánosan pedig bevezetethejük a véletlen folyamat (vagy sztochasztikus folyamat) fogalmát, amely az eseménytér minden $\omega$ eleméhez egy időfüggvényt rendel hozzá. A véletlen folyamat tehát egy kétváltozós $x(\omega, t)$ függvény, mely egy rögzített időpontban valószínűségi változóként funkcionál, egy adott elemi esemény esetében pedig időfüggvényként. 
A következőkben a véletlen folyamatok idő- és frekvenciatartománybeli kezeléséhez szükséges alapvető ismeretek kerülnek bemutatásra, végezetül pedig a zajfolyamatok osztályozására és az értekezés eredményeinek tükrében kiemelten a termikus zaj bemutatására térünk ki.

\subsubsection{Időbeli tulajdonságok leírása}

Ha az eddigiekben egy valószínűségi változó leírására használt matematikai eszközöket (várható érték, szórás, eloszlás- és sűrűségfüggvény) a véletlen folyamatokra is kiterjesztjük, az időfüggés igen bonyolulttá teszi azok kezelését. Bizonyos folyamatok esetén azonban azok statisztikai jellemző nem függenek az időtől, amely lehetőséget biztosít a valószínűségi változók fizikai mennyiségekhez való egyszerű hozzárendelésére. Az ilyen folyamatokat stacionáriusnak nevezzük.

\section{Idő- és sokaságátlag}

A véletlen folyamatok statisztikai vizsgálatánál az időfüggés figyelembevételével megkülönböztetünk idő- és sokaságátlagot. Ez utóbbi szemléletesen nagyszámú független kísérlet kimenetelének számtani átlagát jelenti, amely az elemi eseményhez rendelt valószínűségi változó várható értékéhez tart. Az időátlag ezzel szemben egy kísérlet során mérhető $x(\omega, t)$ jel időbeli átlagát jelenti:

$$
\langle x(\omega, t)\rangle=\lim _{T \rightarrow \infty} \frac{1}{2 T} \int_{-T}^{T} x(\omega, t) d t .
$$

Az $\omega$ elemi eseményt az egyszerűség kedvéért a továbbiakban külön nem jelöljük.

Ha az idő- és sokaságátlag megegyezik, a véletlen folyamatot ergodikusnak nevezzük, melynek a stacionaritás szükséges, de nem elégséges feltétele.

\section{Auto- és keresztkorreláció}

A véletlen folyamat időfüggését illetve több folyamat (vagy gyakorlatiasabb megközelítésben egy kísérlet során mért mennyiségek) közötti kapcsolatot a korreláció-függvényekkel jellemezhetjük. Az $R_{x x}(\tau)$ keresztkorreláció-függvény megadja, hogy a folyamat során mért jel $\tau$ idővel való eltolás esetén milyen kapcsolatban áll önmagával:

$$
R_{x x}(t, \tau)=E(x(t) \cdot x(t+\tau))
$$

Ergodikus folyamatok esetén a két jel szorzatának várható értéke megegyezik azok (2.54) egyenlet szerinti időátlagával:

$$
R_{x x}(\tau)=\langle x(t) \cdot x(t+\tau)\rangle=\lim _{T \rightarrow \infty} \frac{1}{2 T} \int_{-T}^{T} x(t) \cdot x(t+\tau) d t
$$


Ha a jel $t+\tau$ időpillanatban mérhető értéke független annak $t$-ben felvett értékétől, akkor a folyamat korrelálatlan. Ekkor $R_{x x}(\tau)$ értéke 0 mindenhol, kivéve a $\tau=0$ esetet, ahol az a jel négyzetének várható értéke. Továbbá periodikus jelek autokorrelációfüggvénye azonos periódusidejű, periodikus jel lesz.

Hasonló módon bevezethetjük a két folyamat során mért $x(t)$ és $y(t)$ jelek kapcsolatát leíró, és azok közötti $\tau$ időeltolódást jellemző keresztkorreláció-függvényt:

$$
R_{x y}(t, \tau)=E(x(t) \cdot y(t+\tau)),
$$

továbbá ergodikus jelek esetén:

$$
R_{x y}(\tau)=\langle x(t) \cdot y(t+\tau)\rangle=\lim _{T \rightarrow \infty} \frac{1}{2 T} \int_{-T}^{T} x(t) \cdot y(t+\tau) d t .
$$

Ahogyan ezen összefüggésekből is látható, fizikia mennyiségek esetén a két jel keresztkorrelációja azok szorzatának mértékegységével megegyező mértékegységgel rendelkező mennyiség és stacionárius esetben a két mennyiségnek megfeleltetett valószínűségi változók szorzatának várható értékeként kezelhetjük. Ennek megfelelően, ahogy a 2.1.2. fejezetben az együttes eloszlás momentumainál is említésre került, a továbbiakban korrelációként a két valószínűségi változó szorzatának várható értékére hivatkozunk, mely nem keverendő össze a korrelációs koefficienssel.

\subsubsection{Frekvenciatartománybeli leírás}

Számos esetben hasznos a véletlen folyamatokat, illetve sztochasztikus komponenseket tartalmazó jeleket frekvenciatartományban vizsgálnunk. A jelek e tartománybeli képének, azaz spektrumának vizsgálata lehetőséget nyújt a jelek domináns frekvenciakomponenseinek vagy esetleges periodicitásának meghatározásában (mely a 4. fejezetben vizsgált periódusfluktuációk esetén igen fontos lesz számunkra), illetve a folyamatok osztályozásának alapjául is szolgálhat. A következőkben a frekvenciatartományba való transzformáció, a mintavételezett jelek kezelése, a spektrális jellemzők és azok időtartománybeli jellemzőkkel való kapcsolata kerül bemutatásra.

\section{Fourier-transzformáció}

A frekvenciatartománybeli leírás legelterjedtebb eszköze a Fourier-sorfejtés aperiodikus jelekre való kiterjesztése, a Fourier-transzformáció:

$$
X(f)=\int_{-\infty}^{\infty} x(t) e^{-i 2 \pi f t} d t
$$

ahol i a képzetes egység, $f$ pedig a frekvenciát jelöli. 
$X(f)$-et röviden az $x(t)$ jel spektrumának nevezzük, melyből az inverz Fouriertranszformáció segítségével állítható vissza az eredeti jel:

$$
x(t)=\int_{-\infty}^{\infty} X(f) e^{i 2 \pi f t} d f .
$$

\section{Teljesítménysűrüség-spektrum}

A valós folyamatok jellemzése szempontjából sok esetben fizikailag szemléletesebb képet ad az $S(f)$ teljesítménysürüség-spektrum, amely megadja a jel $\left[f_{1}, f_{2}\right]$ frekvenciatartományba jutó $P$ effektív teljesítményt, azaz az e tartományba jutó komponensek négyzetének átlagértékét:

$$
P_{\left[f_{1}, f_{2}\right]}=\int_{f_{1}}^{f_{2}} S(f) d f, \text { ahol } 0 \leq f<\infty .
$$

Látható, hogy a (2.59) egyenlettel definiált spektrummal ellentétben $S(f)$ csak a fizikai jelentéssel bíró, nemnegatív frekvenciákra értelmezett. Az $S_{x x}(f)$ kétoldalas teljesítménysürüség-spektrumot nemnegatív frekvenciák esetén az $S_{x x}(f)=S(f) / 2$, negatív frekvenciákra pedig $S_{x x}(-f)=S_{x x}(f)$ összefüggés szerint határozhatjuk meg, és a Wiener-Hincsin-összefüggések értelmében az autokorreláció-függvény Fouriertranszformáltjaként állítható elő:

$$
S_{x x}(f)=\int_{-\infty}^{\infty} R_{x x}(\tau) e^{-i 2 \pi f t} d \tau
$$

\section{Időben diszkrét jelek frekvenciatartománybeli elemzése}

Egy folyamat spektrális vizsgálatához gyakorlati esetben - a digitális méréstechnika elterjedésével szinte kizárólagosan - időben kvantált, azaz mintavételezett jelek feldolgozása szükséges. Ekkor a $T$ időtartamig mért jelet a legtöbb esetben állandó $f_{\mathrm{s}}$ mintavételi frekvenciával mintavételezzük, az így nyert $N$ adatpont közötti $\Delta t$ időtartam pedig e frekvencia reciproka.

A mintavételi frekvencia megválasztásában a mintavételi tétel nyújt segítséget: ha az $x(t)$ mintavételezett jel $f_{\mathrm{s}} / 2$ frekvenciánál nem kisebb frekvenciájú komponenseinek amplitúdója 0 , a jel információveszteség nélkül rekonstruálható a $\Delta t$ időközönként mért értékeiből. Ha e feltétel sérül méréseink során, azaz a jelet alulmintavételezzük, az aliasing jelensége lép fel, mely meghamisítja mérési eredményeinket, mivel az $f_{\mathrm{s}} / 2$-nél nem kisebb frekvenciakomponensek a $\left[0, f_{\mathrm{s}} / 2\right.$ ) tartományba képződnek le.

Egy $x_{k}=x(k \Delta t)$ mintavételezett adatsor (ahol $k=0,1, \ldots, N-1$ ) spektrumát a diszkrét Fourier-transzformációval (DFT) a (2.63) egyenlet szerint számíthatjuk ki. 


$$
X_{n}=\frac{1}{N} \sum_{k=0}^{N-1} x_{k} e^{-i \frac{2 \pi}{N} n k}
$$

ahol $n=0,1, \ldots, N-1, X_{n}$ pedig a diszkrét Fourier-transzformált komplex vektor.

Az $X_{n}$ diszkrét Fourier-transzformált a $\left[0, f_{\mathrm{s}}\right]$ tartományon az $f_{n}=n \Delta f$ frekvenciákhoz tartozó Fourier-transzformált értékét tartalmazza, ahol $\Delta f=1 / T=1 /(N \Delta t)$ a frekvenciafelbontás, mely csak a mérési időtartamtól függ. A mintavételi tételnek megfelelően csak a $\left[0, f_{\mathrm{s}} / 2\right)$ tartományon értelmezhetjük a valós spektrumot, az $X_{n}$ vektor második fele ennek komplex konjugáltját tartalmazza.

$\mathrm{Az} X_{n}$ spektrumból az inverz transzformációval állítható vissza az $x_{k}$ diszkrét jel:

$$
x_{k}=\sum_{n=0}^{N-1} X_{n} e^{-i \frac{2 \pi}{N} n k}
$$

Megjegyzendő, hogy a DFT definíciója az irodalomban nem konzisztens, a pontok számával való osztást számos esetben nem a direkt, hanem az inverz transzformáció képletében alkalmazzák. Az eljárás műveletigénye $\mathrm{O}\left(N^{2}\right)$, mely bizonyos $N$ értékek esetén az adatsor faktorizációján alapuló gyors Fourier-transzformáció (Fast Fourier Transform, FFT) alkalmazásával $\mathrm{O}(N \cdot \log N)$-re csökkenthető.

Az $\quad x_{k}$ diszkrét jel $f_{n}$ frekvenciájú komponensének amplitúdóját az $A_{n}=2\left|X_{n}\right|$ amplitúdóspektrum, az effektív teljesítményét pedig az egyoldalas $P_{n}$ diszkrét teljesítményspektrum adja meg:

$$
P_{n}=\frac{A_{n}^{2}}{2}=2\left|X_{n}\right|^{2}
$$

ahol $n=0,1, \ldots, N / 2-1$.

A (2.61) egyenlet alapján a $P_{n}$ a teljesítménysűrűség-spektrum $\left[f_{n}, f_{n}+\Delta f\right]$ tartományon vett integrálja, mely alapján a diszkrét egyoldalas teljesítménysűrűségspektrum kiszámítható:

$$
S_{n}=\frac{P_{n}}{\Delta f}=P_{n} \cdot T=2\left|X_{n}\right|^{2} \cdot T .
$$

A gyakorlatban a teljesítménysűrüség-spektrum meghatározásához a (2.62) összefüggés helyett ez utóbbi eljárást célszerű alkalmazni.

\section{Ablakfüggvények}

Egy mintavételezett mérés természetszerűleg véges hosszúságú, melynek köszönhetően a folytonos jeleknél bevezetett Fourier-transzformált is csak diszkrét frekvenciaértékeken értelmezhető. Szemléletesen ez azt jelenti, hogy a teljes adatsorunkat egy periódusnak tekintjük, és Fourier-sorfejtést végzünk. E periodikus kiterjesztés hátránya azonban, hogy ha a mért jelünk nem egész számú periódust 
tartalmaz, akkor törés keletkezik az adatsor szélén, mely az ún. spektrális szétfolyás jelenségéhez vezet.

Ezt a torzító hatást úgy kompenzálhatjuk, hogy a mért jelünket célirányosan megválasztott $w_{n}$ ablakfüggvényekkel szorozzuk meg. Amennyiben nem alkalmazunk speciális ablakfüggvényt, a mért jelünk véges hossza egy egységnyi amplitúdójú négyszögablakkal való szorzásnak feleltethető meg. Az ablakfüggvény típusát az adott feladatnak megfelelően érdemes megválasztani, például azt figyelembevéve, hogy egy spektrális csúcs amplitúdó értékét, frekvenciáját vagy teljesítményét szeretnénk minél pontosabban meghatározni.

A zajanalízisben általában nem indokolt az ablakfüggvények használata, azonban a 4. fejezet tárgyát képező periódusfluktuációk vizsgálatakor szerepet játszhat az eredmények pontossága kapcsán. Az értekezésben bemutatott vizsgálatok során a négyszögablak mellett a periodikus élettani jelek variabilitásának spektrális vizsgálatakor is széles körben használatos Hanning-ablak (más néven Hann-ablak) került alkalmazásra:

$$
w_{n}=\sin ^{2}\left(\frac{\pi n}{N-1}\right) .
$$

\subsubsection{Zajok osztályozása}

A valós kísérletek, illetve mérések során megfigyelt sztochasztikus folyamatokat a továbbiakban átfogóan „zajnak” nevezzük. E zajok igen sokfélék lehetnek, és számos különböző mennyiség ingadozásaként jelentkezhetnek a méréseink során, mégis statisztikai és spektrális tulajdonságaik kapcsán osztályozhatjuk őket.

Ennek egyik lehetséges módja az eloszlásuk szerinti csoportosítás; a 2.1.1. fejezetben leírtak alapján a legsűrűbben előforduló eloszlástípusok közé tartozik a centrális határeloszlás tételének következményeként a normális eloszlás, illetve a numerikus szimulációk kapcsán a véletlenszámgenerálás eredményeként az egyenletes eloszlás.

Legalább ilyen fontos szerepet kap a zajok teljesítménysűrűség-spektrumának jellemzése, mely a gyakorlatban több mérés esetén számolt spektrum átlagolása után történik. Ha a zaj - 2.2.1. fejezetben ismertetett definíció szerint - korrelálatlan, azaz a mérendő mennyiség aktuális értéke teljesen független a korábbiakban felvett értékektől, a teljesítménysűrűség-spektrum a frekvenciától független lesz. Másszóval ezesetben a zaj frekvenciatartománybeli eloszlása egyenletes, minden frekvenciakomponense azonos súllyal szerepel, éppen emiatt - a fény színképének analógiájára - nevezzük az ilyen természetű folyamatokat fehérzajnak. Valós esetben azonban léteznie kell egy felső frekvenciakorlátnak, mely felett a spektrum nulla értéket vesz fel, máskülönben a jel teljesítménye nem lenne véges. 
A korrelált vagy más néven színes zajok spektrális képe is sok esetben jellegzetes; a zajkutatás során az $1 / f^{\alpha}$ alakú teljesítménysűrűség-spektrummal rendelkező fluktuációk kiemelt fontossággal bírnak. Az $\alpha=1$ eset, azaz az $1 / f$ zaj igen általánosan előfordul a természetben, továbbá számos speciális tulajdonságának köszönhetően elméleti szempontból is kitüntetett szerepet kap.

Ezen szempontok szerint jellemezhetjük a számos különböző diszciplina esetében is előforduló jellegzetes zajfolyamatokat, mint például a Brown-mozgást, mely korrelált zaj frekvenciatartománybeli képe $1 / f^{2}$ alakú, és varianciája az idővel arányosan növekszik, azaz nem stacionárius.

Az értekezés első felének tárgya a KLJN rendszer vizsgálata, mely az ellenállások termikus zaján alapul, így a következőkben e folyamat jellemzésére szorítkozunk.

\section{Termikus zaj}

Termikus zajnak vagy más néven Johnson-zajnak nevezzük a vezetők és félvezetők eredő $S_{\mathrm{V}}(f)$ feszültség- és $S_{\mathrm{I}}(f)$ áramfluktuációját, melyet a töltéshordozók véletlenszerű mozgása okoz. A mintán mérhető feszültség és áram teljesítménysűrűség-spektruma:

$$
\begin{aligned}
& S_{\mathrm{V}}(f)=4 k T R, \\
& S_{\mathrm{I}}(f)=\frac{4 k T}{R},
\end{aligned}
$$

ahol $T$ az abszolút hőmérséklet, $R$ a komponens ellenállása és $k$ a Boltzmann-állandó.

Ahogy ezen egyenletekből is látható, a folyamat korrelálatlan, továbbá normális eloszlású. A (2.61) összefüggés alapján - mivel a jel effektív teljesítménye a négyzetének várható értéke - az $V(t)$ és $I(t)$ négyzetének várható értéke (mely nulla várható érték esetén a jel varianciájának felel meg) egy adott, $f_{\mathrm{b}}$ sávszélesség esetén a következőképpen adódnak:

$$
\begin{aligned}
& \left\langle V^{2}(t)\right\rangle=4 k T R f_{\mathrm{b}}, \\
& \left\langle I^{2}(t)\right\rangle=\frac{4 k T f_{\mathrm{b}}}{R} .
\end{aligned}
$$

Az összefüggésekben kihasználtuk, hogy a folyamat ergodikus, azaz az időbeli átlag megegyezik a várható értékkel. 


\section{ZAJ ALAPÚ ABSZOLÚT BIZTONSÁGOS KOMMUNIKÁCIÓ}

Napjainkban az információ biztonságos kezelésének és továbbításának rendkívüli fontossága hétköznapi tevékenységeinket szemlélve is könnyen látható, elég banki, egészségügyi, vagy például a számítógépen, telefonon vagy interneten tárolt és továbbított adatainkra gondolnunk. Az adatok biztonságos forgalmának lebonyolításához sok esetben titkosított kommunikáció szükséges, mellyel a kriptográfia tudománya foglalkozik [36-39]. Néhány évtizeddel ezelőttig a kriptográfiai eljárások célja leginkább az üzenetek titkosítása volt, mára azonban számos más alkalmazási terület is megjelent, mint például a hozzáférés szabályozása, banki tranzakciók, elektronikus kereskedelem vagy a digitális aláírás. A biztonsági követelmények között megjelent a bizalmasság mellett a sértetlenség, rendelkezésre állás, hitelesség és letagadhatatlanság is, így a kriptográfiai eljárások feladatai közé tartozik a rejtjelezésen túl a hitelesítés, időpecsétek készítése, autentikáció, partneridentifikáció, jogosultságok kiosztása és a hozzáférés kezelése is [36]. Fontos szem előtt tartani, hogy a kriptográfiai eljárások nyújtotta elméleti védelem azok helyes implementációja nélkül nem elegendő a biztonságossághoz [37]. Az információbiztonság témakörét számos aspektus szerint vizsgálhatjuk, mely természetesen gyakorlati jelentősége okán igen nagy irodalommal rendelkezik, a továbbiakban az értekezés eredményei szempontjából fontos témakörrel, az üzenetek rejtjelezésének módszertanával foglalkozunk.

\section{Kriptográfiai eljárások, Kerckhoff-elv}

A titkosított kommunikáció során a két kommunikáló fél, hagyományosan Alice és Bob, a védeni kívánt nyílt szöveget (vagy általánosabban adatot) rejtjelezett, azaz titkosított formában küldi el egymásnak, úgy, hogy azt a lehallgató, Eve nem tudja dekódolni. Az üzenet titkosításához és visszaalakításához szükséges kritikus információt kulcsnak nevezzük. A Kerckhoff-elv értelmében a titkosításhoz használt eljárás ismert lehet Eve számára, a titkosítás biztonságossága a modern eljárások 
esetében a kulcs ismeretének hiányán kell, hogy alapuljon [36]. Szimmetrikus kulcsú rejtjelezésről beszélünk, ha a nyílt szöveg titkosításához és megfejtéséhez ugyanaz a kulcs szükséges (ilyen például a DES vagy AES algoritmus), ekkor azonban a két kommunikáló félnek a kulcsot meg kell osztania egymással az üzenetváltás előtt. Diffie, Hellman és Merkle 1976-ban [40] megmutatta, hogy nyilvános csatornán is létrehozhat Alice és Bob titkos kulcsot, melyet aztán használhatnak szimmetrikus kulcsú rejtjelezésre. Ez az eredmény szakított az addig elterjedt nézettel, miszerint a titkosított kommunikációhoz kell egy, a kommunikáló felek által előzetesen megbeszélt, közös „titok” [37]. A nyilvános kulcsú (vagy aszimmetrikus, két kulcsú) titkosítási eljárások - mint amilyen a manapság is széles körben elterjedt RSA algoritmus - lényege, hogy az üzenet titkosításához Alice egy publikus kulcsot használhat, azonban a megfejtéséhez szükséges ún. magánkulcsot még ő sem, csak Bob ismeri [37, 39]. A kommunikáció fordított irányban teljesen hasonlóan történik, így a két fél előzetes egyeztetése nélkül is megvalósítható a titkosított kommunikáció, és bár a publikus kulccsal Eve is küldhet rejtjelezett üzenetet az egyik félnek, a digitális aláírás segítségével arra is létezik megoldás, hogy az üzenetet megkapó fél biztos lehessen benne, hogy azt a másik fél küldte. Az eljárás, mivel műveletigénye jóval nagyobb a kommunikáló felek számára, a manapság elterjedt alkalmazások jelentős részében a titkos kulcsú kommunikáció kiegészítéseként szolgál.

Természetesen a titkosítási eljárásokkal szemben támasztott legfontosabb követelmények, hogy azok a kulcs ismerete nélkül ne legyenek feltörhetőek, illetve hogy a kulcs ne legyen megismerhető Eve számára. Ez az előzőekben említett eljárások esetén csak gyakorlati értelemben biztosított, mivel biztonságosságuk azon alapszik, hogy bizonyos matematika problémák (például a faktorizáció) algoritmikus tulajdonságai miatt Eve nem rendelkezik elegendő erőforrással, hogy a ma ismert módszerekkel gyakorlati szempontból elfogadható időn belül kiszámítása a kulcsot, vagy máshogy megfejtse az üzenetet. Ezt feltételes (conditional), erős (strong) vagy számítási (computational) biztonságnak nevezzük, és természetesen a technológia fejlődéséből adódóan a ma ide sorolt eljárások - matematikai megfontolásokon alapuló támadásokkal, vagy akár az összes lehetséges kulcs kipróbálásával („Brute force") - idővel feltörhetővé válhatnak, ahogyan számos korábban elterjedt módszer esetén történt [37]. Shor 1994-ben megmutatta, hogy egy kvantumszámítógépekre tervezett algoritmussal polinomiális időn belül végezhető el az RSA feltöréséhez szükséges faktorizáció, azaz az egész számok prímfelbontása [41]. Emellett matematikailag sem bizonyított, hogy nem létezik a feltörést kellő idôn belül végrehajtó algoritmus, illetve, hogy az RSA feltöréséhez a faktorizáció hatékony megoldása feltétlenül szükséges. 


\section{Abszolút biztonságos kommunikáció}

Információelméleti szempontból akkor nevezünk egy titkosítási eljárást abszolút, elméletileg vagy tökéletesen biztonságosnak (unconditonally secure), ha Eve akkor sem jut semmilyen információhoz a nyílt szöveggel kapcsolatban (a hosszán kívül), ha számára végtelen számítási kapacitás és idő áll rendelkezésre. Shannon 1945-ben bizonyította, hogy ez csak abban az esetben lehetséges, ha a kulcsot csak egyszer használjuk, teljesen véletlenszerű, és hossza legalább akkora, mint a titkosítandó adaté [42]. Ezt nevezzük egyszer használatos bitmintának (OneTime Pad, OTP), melynél a titkosítás és a megfejtés is a nyílt/titkosított adat bitjeinek a kulcsbit megfelelő bitjeivel végzett bitenkénti XOR művelet. A módszer feltörhetetlensége könnyen belátható; mivel a nyílt szöveg minden karakteréhez egy külön, véletlenszerű kulcs karakter (vagy az adat bitjéhez külön, véletlenszerü kulcsbit) tartozik, a titkosított szöveghez ugyanakkora valószínűséggel tetszőleges számú, értelmes megfejtés társítható. Mivel a kulcsot csak egyszer használjuk, így statisztikai következtetés több lehallgatott kommunikáció esetén sem lehetséges.

Az elméleti bizonyítás előtt a Vernam-féle titkosítás (mely az OTP 1919-ben szabadalmaztatott változata) általánosításaként Mauborgne javasolt egy ennek megfelelő eljárást, amely gyakorlati alkalmazásakor a II. világháborúban rendszertelen betűsorozatokból álló kulcsokat tartalmazó kódkönyveket használtak. Azonban ezek legépelése nem volt teljesen véletlenszerü, a gépírók felvettek egy ritmust, például általában a billentyűzet jobb oldalán található karakter után egy, a bal oldalán elhelyezkedőt ütöttek le [37]. Erre a problémára azonban a nem túl nagy méretű kulcsok esetén a pszeudo-véletlenszámgenerátorok, általánosan pedig a manapság egyre könnyeben elérhető, fizikai jelenségekből származó zajokon alapuló valódi véletlenszámgenerátorok nyújtanak megoldást.

Azonban, ahogy a kódkönyvek példája is mutatja, a szimmetrikus kulcsú technikából adódóan, ezekből a nagy méretű kulcsokból Alice-nek és Bob-nak is rendelkeznie kell egy példánnyal, vagy valamilyen módon el kell juttatniuk azt a másiknak. Erre alkalmas lehet egy fizikai adathordozó használata, azonban az könnyen másolható, sérülékeny és Eve számára hozzáférhető lehet. Továbbá, ha létezik mód arra, hogy biztonságos módon továbbítsák a titkosításhoz szükséges kulcsot egy kommunikációs csatornán, akkor akár magát a titkosítandó üzenetet is elküldhetnék helyette. A kulcs véges hossza is megszorítást jelenthet, továbbá a rendszer kiemelten érzékeny a jelek kiesésére vagy beékelődésére [37]. Ezen kritikák alapján az OTP, elméleti jelentőségén túl - a kriptográfia néhány igen speciális használati területén kívül, mint például ügynökök utasítása rádióadásokon keresztül - a gyakorlati alkalmazás szempontjából sokáig nem jelentett valós alternatívát. 


\section{Kulcsmegosztó módszerek, kvantumkriptográfia}

Ezen változtatott a kvantumos kulcsmegosztás (Quantum Key Distribution, QKD) illetve a KLJN protokoll, mely az értekezés tárgyát képezi. Ezen kulcsmegosztó (vagy más néven kulcsgeneráló, kulcs-szétosztó, kulcstovábbító) módszerek célja nem egy előre elkészített kulcsbitsorozat biztonságos eljuttatása a másik félnek, hanem egy fizikai mennyiség mérésével a kulcsbiteknek a kommunikáció során való közös generálása úgy, hogy Eve ne tudja azt meghatározni, vagy a mérésével felfedje a lehallgatás tényét. Az így generált, véletlenszerú bitsorozatból álló kulcs alkalmas az elküldeni kívánt adat OTP módszerrel való titkosítására. A titkosított információt ezután egy autentikált, publikus csatornán elküldheti egymásnak a két kommunikáló fél, hiszen az Eve számára - a kulcs ismerete nélkül - elméletileg is megfejthetetlen. A következőkben ismertetett kulcsmegosztó módszerek áttörése az, hogy a kulcsmegosztás folyamatát lehallgató Eve elméletileg semmilyen információt nem tud szerezni a kulcsról lebukás nélkül (így az OTP módszerrel a titkosítás abszolút biztonságos), szemben például a Diffie-Hellman módszerrel, ahol a támadó a magánkulcs kiszámításához minden információval rendelkezik, csak a korlátozott erőforrása miatt nem tudja kellő gyorsasággal azt meghatározni.

Az első QKD eljárást Bennett és Brassard javasolta 1984-ben (BB84 protokoll), mely megalapozta a kvantumkriptográfia tudományát [43]. A kvantumos kulcsmegosztás lényege, hogy kulcsot kvantumos bitek (qubitek) formájában juttatja el egymáshoz Alice és Bob, ebből következően, a kvantumrendszerek azon tulajdonsága alapján, miszerint a rajtuk végrehajtott mérés irreverzibilis változást okoz a rendszerben, Eve hallgatózása befolyásolja a qubitek értékét, így statisztikai módszerrel felfedezhető.

A qubiteket a gyakorlatban legtöbbször fotonok polarizációs állapotai reprezentálják. A felek kétféle polárszűrővel állítják és mérik be a fotonokat, ezek megválasztása határozza meg a foton polarizációjának bázisát. A rektilineáris és diagonális szürő által meghatározott bázisok ortonormált elemei a horizontálisan (0), és vertikálisan (1), illetve $45^{\circ}$ (0) és $135^{\circ}$ (1) értékű polarizációs szögek. A kulcsmegosztás során a felek véletlenszerúen váltogatják polárszűrőiket, így Bob minden olyan esetben, mikor azonosan választanak bázist, helyesen határozza meg az Alice által beállított polarizációs szöget, azaz a qubit értékét, különböző szűrők használatakor pedig (megfelelő kulcshossz esetén) az esetek felében, hiszen a másik bázishoz tartozó két polarizációs irányt ugyanakkora eséllyel mérheti 0-nak, mint 1nek. Ezután a protokoll részét képező publikus csatornán megosztják egymással a választott bázisok sorozatát, és kitörlik a kulcsból azokat az eseteket (körülbelül az átküldött bitek felét), amikor a bázisok nem egyeztek meg. Mivel a qubitek értékére ebből nem lehet következtetni, a publikus csatorna lehallgatása nem jelent plusz információt Eve számára. Ha Eve a kvantumos csatornán mér, azaz beméri a 
fotonokat, azzal csak abban az esetben nem változtatja meg azok állapotát, ha helyes bázist használt, azonban azok véletlenszerű megválasztása miatt erre nincs lehetősége a kulcs egészét tekintve. Így, ha Alice és Bob a kulcs használható felének egy további részét feláldozza arra, hogy a nyilvános csatornán egyeztesse a méréseket, fény derül a lehallgatásra. Eve természetesen ezt elkerülendő megpróbálhatja lemásolni a kvantumállapotot, és azon mérést végezni, azonban erre lebukás nélkül a nemklónozhatósági tételből következően nincs lehetősége. Számos további kvantumos kulcsmegosztó protokoll is megjelent azóta, azonban a módszerek mindegyike ez utóbbi tulajdonságon alapul.

Az ideális QKD módszer az előzőekben bemutatott elméleti megfontolások alapján abszolút biztonságos, azaz Eve észrevétlenül nem tud információt szerezni a kulcsról. Eve-nek minden kulcsbit eltalálására 50\% esélye van, azonban ha a kulcs bitjeinek felét helyesen határozza is meg, nincs információja arról, melyek ezek. A kulcsmegosztó módszerek valós, fizikai implementációja során azonban az ideális esettől való eltérésből fakadóan felléphet információszivárgás, azaz, bár Eve a kommunikációt nem tudja feltörni, $p=0,5$-nél nagyobb valószínűséggel találhatja el a kulcsbitek értékét, azaz a kulcs bitjeinek több mint felét határozza meg helyesen. Emellett gyakorlati esetben az sem garantálható, hogy Alice és Bob minden hasznos kulcsbit esetén helyesen határozta meg azok értékét. Fontos különválasztani (ahogyan a későbbiekben ismertetett protokollok esetén is), hogy a módszer ettől függetlenül elméleti szempontból abszolút biztonságos, a kérdés az, hogy annak hardveres megvalósítása mekkora mértékű információszivárgással és mellette mennyire komplex és költséges eszközökkel lehetséges.

A protokoll leírásakor egy kulcsbit értékét egy foton polarizációs állapota határozta meg, melyet annak megváltoztatása nélkül Eve nem tud megmérni, ugyanakkor a gyakorlatban több foton átvitele szükséges egy qubit cseréjéhez, így Evenek lehetősége adódik azoknak csak egy részét módosítani. Továbbá, a QKD-t megvalósító optikai rendszerekben az optikai kábel, a detektorok és egyéb komponensek zaja, illetve az a tény, hogy a kvantumállapotok nem erősíthetőek fel, nehezebbé teszi az Eve hallgatózásának statisztikai módszerekkel való kimutatását [21, 44]. A rendszer megépítése és üzemeltetése a szükséges speciális optikai, optoelektronikai eszközök, a kommunikációs csatornát jelentő optikai kábel, illetve a rezgésekre, hőmérsékletváltozásra és egyéb környezeti paraméterekre való érzékenysége miatt igen bonyolult és költséges. A technológia fejlődésével természetesen mind a kommunikáció sebessége, az átviteli közeg típusa, mind a kommunikáló felek közötti távolság tekintetében folyamatos előrelépések történnek, továbbá már léteznek kereskedelmi forgalomban is kapható eszközök. Azonban sok esetben az eszközök, a felépítésükből következő hiányosságokat kihasználva feltörhetőnek bizonyultak [45, 46], továbbá fontos a kísérleti eredmények számos szempontra kiterjedő értékelése, mivel az abszolút biztonságossághoz szükséges 
kvantumfizikai elvek érvényességéhez rendkívül szigorú követelmények teljesítése szükséges [44].

$\mathrm{Az}$ Eve által nem lehallgatható kulcsmegosztás lehetősége, illetve az implementációk hatékonyságának növelésére bevezetett eljárások („Information reconciliation” Alice és Bob hibás bitjeinek csökkentésére és „Privacy amplification” az Eve által megszerezhető információ redukálására) a kvantumos titkosításon túlmutatóan is fontos eredmények az abszolút biztonságos kommunikáció megvalósítása szempontjából.

A QKD esetén a kvantummechanika törvényei szavatolják a kommunikáció biztonságát, azonban felmerül a kérdés, hogy egy, a klasszikus fizika törvényein alapuló rendszer is lehet-e abszolút biztonságos? Erre adott választ Kish László Béla 2005-ben javasolt, az ellenállások termikus zaján alapuló kulcsmegosztó módszere, a KLJN protokoll, mely az értekezés eredményeinek tárgyát képezi [21, 47].

A következőkben bemutatásra kerül a kulcsmegosztó protokoll, illetve röviden ismertetem az ahhoz kapcsolódó főbb eredményeket, támadási lehetőségeket és a rendszer biztonságosságára vonatkozó, jelenleg elfogadott megállapításokat. Ezután részletesen ismertetem a disszertáció első három tézispontjában összefoglalt eredményeimet. Vizsgálataim középpontjában az a kérdéskör állt, hogy a KLJN protokoll, majd annak általam általánosított változatai esetén milyen feltételekkel lehetséges a kulcscsere zajokkal történő megvalósítása úgy, hogy Eve ne jusson információhoz a kulcsot illetően. A kérdést a valószínűségszámítás és a matematikai statisztika eszköztárával vizsgáltam, így az eredmények értelmezéséhez a kriptográfia eszköztárának mélyrehatóbb ismerete az értekezésben bevezetett fogalmakon túl nem szükséges.

\subsection{A KLJN kulcsmegosztó protokoll}

A Kirchhoff-Law-Johnson-Noise (KLJN) kulcsmegosztó protokoll (más néven Kish Key Distribution, KKD illetve Kish Chiper) az ellenállások termikus zaját felhasználva elegáns és meglepően egyszerủ módon nyújt lehetőséget az abszolút biztonságos kommunikáció megvalósítására, ezen felül biztonságossága pusztán a klasszikus fizika törvényein alapszik [21, 47]. A csupán néhány elektronikai alkatrészből álló rendszer egyszerű, nagyságrendekkel kisebb költséggel megvalósítható és robosztus, így ígéretes alternatívát nyújt a kvantumkriptográfiával szemben. A következőkben a protokollal kapcsolatos legfontosabb eredmények kerülnek röviden ismertetésre, melyekbe a KLJN átfogó történetén keresztül Kish protokollról írt könyve ad részletes betekintést [45].

Bár a protokoll célja a QKD-hez hasonlóan a kulcsmegosztás, ezzel érhető el a biztonságos kommunikáció megvalósítása a publikus csatornán, továbbá a módszer 
fizikai kapcsolatot jelent a két fél között, így a továbbiakban „kommunikáció” alatt a kulcscserével együtt vett teljes folyamatot értjük.

\subsubsection{A protokoll bemutatása}

A 3.1. ábrán látható KLJN rendszerben a két kommunikáló fél azonos értékű ellenálláspárral rendelkezik $\left(R_{\mathrm{L}}, R_{\mathrm{H}}\right)$, melyek értékére az egyetlen megkötés, hogy egy adott fél által használt két ellenállás értéke nem lehet egyenlő $\left(R_{\mathrm{L}} \neq R_{\mathrm{H}}\right)$. Alice és Bob a kommunikáció során véletlenszerűen kapcsolja az ellenálláspár egyik elemét a kommunikációs vezetékre, amelyen Eve-nek az áramerősséget $\left(I_{\mathrm{E}}(t)\right)$ és a feszültséget $\left(V_{\mathrm{E}}(t)\right)$ van lehetősége mérni.

A két fél által használt kapcsolók a választott kis és nagy értékű ellenállásoknak megfelelően $\mathrm{L}$ és $\mathrm{H}$ állapotban állhatnak, így a rendszer négy lehetséges állapotát Alice és Bob kapcsolóit sorrendben tekintve a következőképp jelöljük: LL, LH, HL és $\mathrm{HH}$.

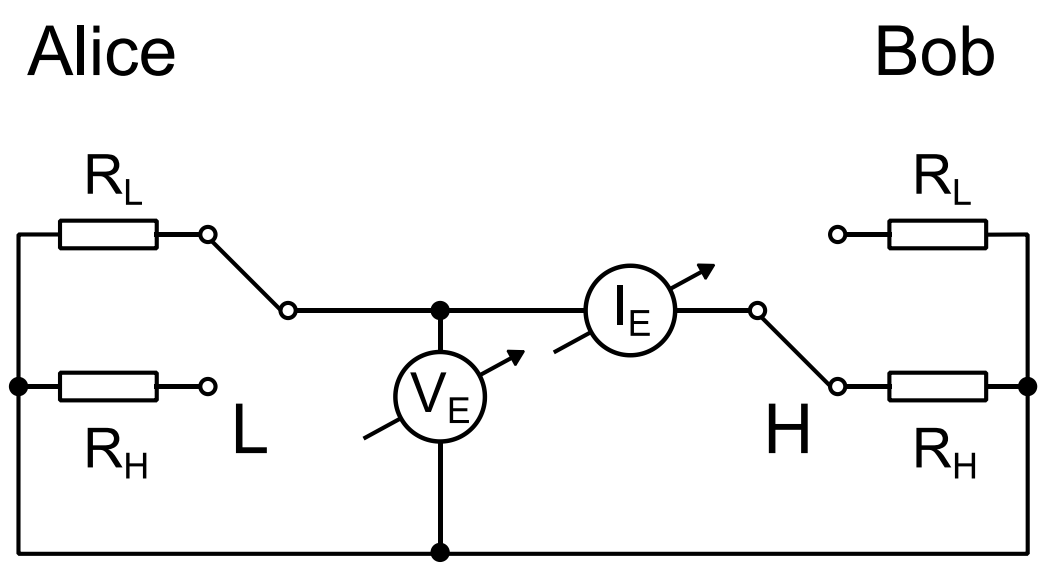

3.1. ábra: A KLJN rendszer modellje (LH állapotban).

Fontos megjegyezni, hogy a legtöbb esetben a felhasznált komponenseket földelve szokták ábrázolni, azonban - mivel a két fél között nagy távolságok is elképzelhetőek - közös referenciavezeték használata szükséges a feszültségek helyes megállapításához.

Az ellenállások - 2.2.3. fejezetben ismertetett - termikus zajából következően a vezetéken mérhető áramerősség- és feszültségzaj középértéke nulla, azaz $\left\langle I_{E}(t)\right\rangle=0$ és $\left\langle V_{\mathrm{E}}(t)\right\rangle=0$. Eve szemszögéből az Alice és Bob által használt ellenállás $\left(R_{\mathrm{A}}, R_{\mathrm{B}}\right)$ párhuzamosan van kapcsolva, így termikus egyensúly esetén, a (2.68) és (2.69) Johnson-formulák és a Kirchhoff-törvények alapján az azok termikus zajából adódó, a vezetéken mérhető feszültség és áramerősség teljesítménysűrűség-spektruma, $S_{\mathrm{VE}}(f)$ és $S_{\mathrm{IE}}(f)$ a következő módon számítható ki:

$$
S_{\mathrm{VE}}(f)=\frac{4 k T R_{\mathrm{A}} R_{\mathrm{B}}}{R_{\mathrm{A}}+R_{\mathrm{B}}},
$$




$$
S_{\mathrm{IE}}(f)=\frac{4 k T}{R_{\mathrm{A}}+R_{\mathrm{B}}},
$$

ahol $k$ a Boltzmann-állandó és $T$ a közös, abszolút hőmérséklet.

Az Eve által mérhető mennyiségek varianciái az előzőek alapján:

$$
\begin{aligned}
& \left\langle V_{\mathrm{E}}^{2}(t)\right\rangle=S_{\mathrm{VE}}(f) f_{\mathrm{b}}, \\
& \left\langle I_{\mathrm{E}}^{2}(t)\right\rangle=S_{\mathrm{IE}}(f) f_{\mathrm{b}},
\end{aligned}
$$

ahol $f_{\mathrm{b}}$ a zaj sávszélessége.

Mivel a termikus zaj normális eloszlású, $S_{\mathrm{VE}}(f)$ és $S_{\mathrm{IE}}(f)$ illetve az $I_{\mathrm{E}}(t)$ és $V_{\mathrm{E}}(t)$ ezekkel arányos varianciái - a normális eloszlás 2.1.1. fejezetben bemutatott speciális tulajdonságai alapján - tökéletesen meghatározzák a mérhető áram- és feszültségzajokat [48]. Ez alapján, ahogyan a (3.1) - (3.4) egyenletekből látható, Eve az LL és HH esetekkel szemben az LH és HL eseteket nem tudja statisztikailag megkülönböztetni, azaz nem rendelkezik információval arról, hogy melyik oldalon választották a kis, és melyik oldalon a nagy értékű ellenállást. Ezzel szemben Alice és Bob, ismerve saját kapcsolójának állását, meg tudja mondani a másik fél választását. Látható tehát, hogy az LH és HL állapotok esetén egy bitnyi információ biztonságosan megosztható.

A rendszer abszolút biztonságosságának klasszikus fizikai bizonyítása azon alapszik, hogy termikus egyensúlyban a termodinamika 2. főtétele alapján nincs energiaáramlás a két oldal között, azaz nem nyerhető információ a rendszer állapotáról. Mivel nincsen energiaáramlás, a vezetéken mérhető $P=<V_{\mathrm{E}}(t) I_{\mathrm{E}}(t)>$ teljesítmény, azaz $I_{\mathrm{E}}(t)$ és $V_{\mathrm{E}}(t)$ korrelációja nulla $[21,48]$.

Természetesen szobahőmérsékleten (vagy akár annak többszörösén) a mérhető feszültség és áramerősség jelek effektív értéke vagy varianciája rendkívül kis értékű, azonban - a QKD esetével ellentétben - ez a probléma egyszerűen orvosolható, mert a mérendő zajok külső zajgenerátorok alkalmazásával a 3.2. ábrán látható módon kellően nagyok lehetnek. Mivel a Johnson-zaj varianciája és a hőmérséklet közötti kapcsolat a (2.70) és (2.71) egyenleteknek megfelelően lineáris, a normális eloszlású, sávkorlátolt fehér zajt előállító mesterséges zajgenerátorokkal elért megfelelő jelerősség rendkívül nagy $\left(10^{9} \mathrm{~K}\right)$ „virtuális” hőmérsékletnek felel meg. Az elrendezés biztonságosságához ezen ekvivalens hőmérséklet biztosítása szükséges mindkét oldalon, melyhez a független zajgenerátorok által előállított, L és $\mathrm{H}$ állapothoz tartozó feszültségzajok varianciájának a (2.70) egyenletből következően az ezen állapotokhoz tartozó ellenállások arányával kell skálázódnia. 
Alice Bob

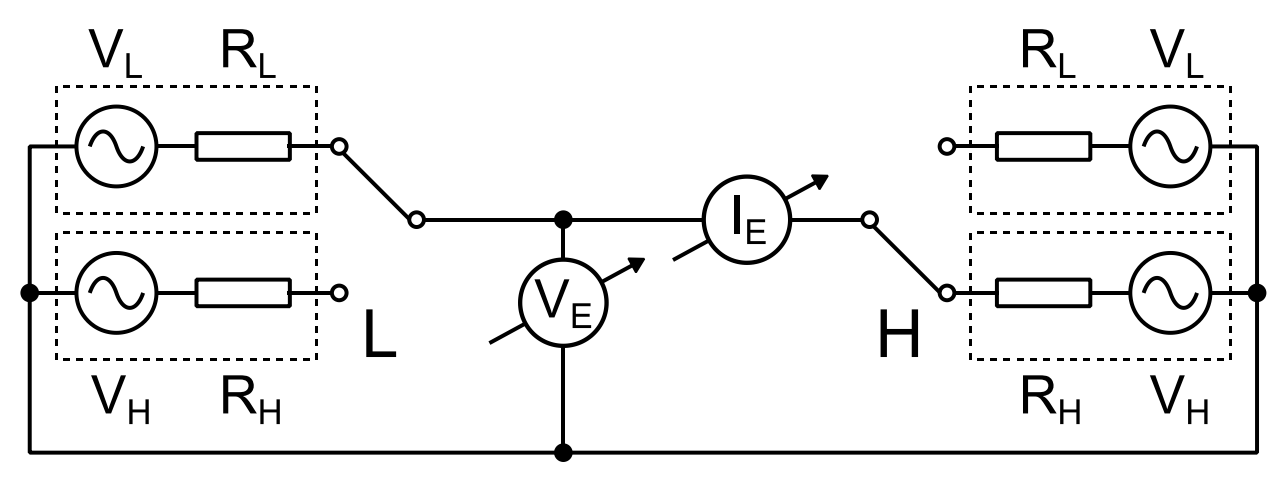

3.2. ábra: A KLJN rendszer ekvivalens modellje zajgenerátorok alkalmazásával (LH állapotban).

A gyakorlati megvalósítás szempontjából ez rendkívüli előnyt jelent a kvantumkriptográfiával szemben, ahol az egyik fő problémát az jelentette, hogy a csatorna és detektorok zaja jelentősen megnehezíti Eve hallgatózásának észlelését. Mivel a két elrendezés ekvivalens, a termodinamikai megközelítésű bizonyítás ezen, 3.2. ábrán látható elrendezés esetén is érvényes.

A (3.3) és (3.4) egyenletekben is szereplő $f_{b}$ sávszélességre a Kirchhofftörvények által szabott következő kritérium tekinthető a KLJN protokoll alkalmazhatóságát befolyásoló egyik legszigorúbb megkötésnek. A hullámterjedés kialakulásának elkerüléséhez a kommunikációs vezeték $L$ hosszának jelentősen kisebbnek kell lennie, mint az $f_{\mathrm{b}}$ sávszélességből következő maximális frekvencia és az elektromágneses hullámok $c$ terjedési sebessége által meghatározott legnagyobb $\lambda_{\max }$ hullámhossz:

$$
L \ll \lambda_{\max }=\frac{c}{f_{\mathrm{b}}} .
$$

$\mathrm{Az}$ ennek teljesítéséhez szükséges sávkorlátolt fehér zaj spektrumának az $f_{\mathrm{b}}$ frekvenciaérték alatt konstans értékűnek, míg az afeletti tartományon nullának kell lennie. Ebből következően az $f_{\mathrm{b}}$ által meghatározott $\tau$ korrelációs időn belül mért értékek nem lesznek függetlenek, azaz a feszültség- és áramzajok statisztikáján alapuló kulcsbitek meghatározásához $\tau$ többszöröséig kell mérni. Mint látható tehát, a vezeték hossza - mely a különböző alkalmazási területeken igen különböző lehet határozza meg a kommunikáció sebességét. E sebesség a QKD kulcsmegosztó protokolléval nagyságrendileg egyezőnek mutatkozik [21, 49].

A rendszer stacionárius állapotának sávszélességtől független statisztikai vizsgálatához az egy bit átviteléhez szükséges $k$ statisztikailag független pontok számát célravezető használni, mely a mintavételi tétel alapján egy bit átviteléhez szükséges $T$ idő alatt: $k=2 f_{\mathrm{b}} T$ [45]. 
A kulcscsere során tehát Alice és Bob minden bit esetén véletlenszerűen választ ellenállást, így a biztonságos LH és HL bitek aránya 50\%-hoz tart, majd a kulcsból a HH és LL állapotokhoz tartozó bitek, azaz a QKD-hoz hasonlósan az esetek fele törlésre kerül, amelyhez akár a törlendő bitek sorszáma a protokollhoz tartozó publikus, autentikált csatornán egyeztethető is a két fél által. Alice és Bob ezen a publikus csatornán egyeztetheti továbbá a vezetéken végzett méréseinek eredményét az aktív támadások elkerüléséhez, majd a kulcscsere végeztével azon az OTP módszerrel rejtjelezett információt is megoszthatja egymással.

A Kerckhoff-elvnek megfelelően Eve a rendszerről minden információval rendelkezhet, így ismerheti az ellenálláspárok értékét és a zajgenerátorok effektív értékét is, az előbbiekben ismertettek alapján a módszer abszolút biztonságosságát az garantálja, hogy az LH és HL eseteket nem tudja megkülönböztetni. Ha a feszültségzajok helyett determinisztikus jeleket alkalmazna Alice és Bob, melyeket a Kerckhoff-elv értelmében Eve ismerhet, lehetősége adódna meghatározni a vezeték egy pontján tetszőleges időpillanatban mérhető jelet a két esetben, de az alkalmazott feszültségjelek ismerete nélkül is lehetősége adódna különválasztani a két fél által a vezetékre kapcsolt jeleket. A biztonságosság kulcsa a vezetéken kialakuló véletlenszerű áram- és feszültségjel, melynek statisztikai jellemzői megegyeznek LH és HL esetben.

\subsubsection{Támadási kísérletek, gyakorlati alkalmazások és további protokollok}

A KLJN protokoll rámutatott, hogy az abszolút biztonságos kommunikációhoz nem szükséges a kvantumrendszerekre jellemző speciális törvényszerüségek kihasználása, továbbá a QKD eljáráshoz szükséges rendkívül komplex, költséges és érzékeny berendezésekkel szemben a KLJN-t implementáló robosztus rendszer könnyen beszerezhető és hétköznapi alkatrészekből előállítható. Ebből következően megjelenése igen nagy figyelmet kapott és számos feltörési kísérlet tárgyát képezte [47].

\section{Aktív feltörési kísérletek}

Az első támadást Kish írta le a protokollt bevezető közleményében [21]. A feltörési kísérlet során Eve nem csak lehallgató, hanem aktív támadóként lép fel; véletlenszerű áramot injektál a vezetékbe („current injection attack”). Ekkor a két irányban mérhető áramerősség és a beinjektált áram keresztkorrelációjából Eve kiderítheti, melyik oldalon melyik ellenállást használják a kommunikáló felek. Azonban a publikus csatornán a mérési eredményekből azonnal fény derül a támadásra, így legfeljebb egy bitnyi információt szerezhet Eve a kulcsról. A gyakorlati megvalósítás során használt nem ideális komponenseket is figyelembe vevő szimuláció később megmutatta, hogy kis mértékű áram beinjektálása esetén a két fél 
által mérhető áramértékek apró eltérései nehezítik a támadás felfedését, azonban ez Eve számára is rendkívül kicsi információ megszerzését teszi csak lehetővé, továbbá a vezetéken mért fesztültségértékek megosztásával kivitelezhető a megfelelően gyors észlelés [50].

Ugyancsak Kish, nem sokkal a protokoll bevezetése után rámutatott, hogy a rendszer rendkívül ellenálló a közbeékelődéses támadásokkal („man-in-the-middle attack”) szemben. Ez a támadási forma igen veszélyes, a feltételes biztonságot nyújtó, manapság elterjedt titkosítások esetén is nagy kockázatot jelent. Az ilyen típusú támadásoknál Eve a kommunikációs csatornát megszakítva mindkét fél irányában a partner szerepét igyekszik eljátszani, és ezzel, a kommunikáló feleket hamis információval ellátva elszakítani őket a külvilágtól. Az RSA algoritmus esetében például fontos, hogy a nyilvános kulcsot a két fél autentikált csatornán juttassa el egymásnak, vagy megbízható szolgáltatón keresztül ossza meg azt, máskülönben Eve elérheti, hogy Alice és Bob az ő általa generált kulccsal titkosítsa az üzenetét. A KLJN protokoll esetén könnyen belátható, hogy ha Eve megszakítja a vezetéket, és egy-egy, az Alice és Bob által használttal egyező kommunikátort kapcsol a két irányba, az autentikált, publikus csatornán megosztott mérési eredmények alapján azonnal felfedezhető a támadás, hiszen a két, Eve által használt zajgenerátor által előállított feszültségzaj statisztikailag független. Ha Eve ehelyett két, egymással egyező jelet előállító áramgenerátort köt a rendszerbe, a publikus csatornán megosztott áramerősség értékek alapján nem fedhető fel a kiléte. Azonban a feszültségértékek megosztása azonnal lebuktatja a támadót, hiszen Alice és Bob zajgenerátorai statisztikailag függetlenek, így a vezeték két végén mérhető pillanatnyi feszültségértékek nem egyeznek meg. Teljesen hasonló módon nulla bitnyi információ nyerhető a támadás leleplezése előtt két, egyező jelet előállító feszültséggenerátor alkalmazása esetén. A KLJN ezen tulajdonsága igen kedvező, hiszen a QKD esetében csak több bitnyi kulcscsere után fedhető fel gyakorlati esetben a támadás ténye [51].

\section{Az ideálistól eltérő, valós rendszerek elleni támadások}

Számos támadási kísérlet a gyakorlatban megvalósítható rendszer ideálistól való eltérését használta ki. Az egyik legkézenfekvőbb ilyen eltérés a kommunikációs vezeték nem nulla értékű ellenállása, amelynek hatására a vezeték két végén mérhető feszültség eltéréséből Eve következtetéseket vonhat le [47, 52-55]. Kish később rámutatott, hogy a vezeték két végén mérhető teljesítmény (azaz a feszültség és áramerősség korrelációja) alapján Eve még több információhoz juthat [56]. Azonban ez nem elegendő a kommunikáció feltöréséhez, csupán információszivárgás lép fel. Továbbá Kish adott egy kompenzációs eljárást is, amellyel Alice és Bob a vezeték ellenállásértékének ismeretében a szivárgást teljes mértékben kompenzálhatja [56]. 
Ezen eredményt az értekezés eredményeivel kapcsolatban a 3.4. fejezetben részletesebben is megvizsgáljuk.

Hasonlóan az ideális esettől való eltérést aknázza ki a vezeték és a kommunikátorok hőmérsékletkülönbségén alapuló támadás [57, 58]. A termikus egyensúly, melyen az abszolút biztonságosság bizonyítása alapszik, nem teljesül, ez azonban a külső zajgenerátorok alkalmazásával elért virtuális, extrém magas hőmérséklet esetén igen kis mértékű szivárgást okoz [58]. Jelentősebb szivárgás léphet fel a vezeték kapacitásából következően [58-61], azonban ez az ún. „capacitor killer" elrendezés implementálásával szinte teljes mértékben eliminálható.

$\mathrm{Az}$ eddigiekben bemutatott támadások esetén igaz, hogy a fellépő információszivárgás, a QKD módszer esetében is alkalmazott Privacy Amplification eljárással csökkenthető $[59,62]$. Az elv lényege, hogy Alice és Bob a kulcs méretének csökkentésével jelentős mértékben csökkentheti az Eve által megszerzett információt, például a kulcson végrehajtott XOR művelet megfelelő alkalmazásával.

Ahogyan a kvantumkriptogáfia esetében is említésre került, a kulcsmegosztó protokollok implementációjakor, azaz ideálistól eltérő esetben információszivárgás léphet fel, ez azonban információelméleti szempontból nem befolyásolja az ideális rendszer abszolút biztonságosságát. Ahogyan Kish ezzel kapcsolatos bizonyítása is mutatja, az ezen eltérések hatására Eve számára elérhető információ az előbbiekben ismertetett eljárások alkalmazásával tetszőleges mértékben csökkenthető [48].

\section{A rendszer implementációja}

A KLJN protokoll első hardveres implementációját Mingesz Róbert, Gingl Zoltán és Kish László hajtották végre 2008-ban [49]. A megépített két kommunikátor különböző, modellezett vezetékhosszak esetén $(2-2000 \mathrm{~km})$ végrehajtott tesztje során a legrövidebb vezeték esetén 100 bit/másodpercnek, míg a leghosszabb vezeték esetében 0,1 bit/másodpercnek adódott. Az elért sebességek nagyságrendileg egyeztek a QKD módszerrel elérhetővel (megjegyzendő, hogy ezen értékek mindkét területen jelentős mértékben növelhetőek a folyamatosan megjelenő elméleti eredmények és technológiai fejlődésnek köszönhetően), míg Alice és Bob hibás bit találati aránya $(0,02 \%)$ és a vezetékellenállásból fakadó információszivárgás (0,19\%) mértéke jelentősen kisebb értékek, mint a legtöbb QKD implementáció esetében. A rendszer kísérleti vizsgálatának konklúziója alátámasztotta a támadások kapcsán említett tulajdonságokat, miszerint az áram injektálásán alapuló feltörési kísérlet egy bitnyi információ átvitele nélkül felfedezhető, a hőmérsékleti eltéréseken alapuló támadás esetén pedig nem mérhető kimutatható mértékű információszivárgás. A rendszer hardveres megvalósítása megmutatta a protokoll gyakorlati alkalmazhatóságát, továbbá a kulcscsere technikai megvalósításának részleteire is rávilágított. 


\section{Tranzienseken és a jelek időfüggésén alapuló támadások}

$\mathrm{Az}$ eddigiekben egy bit biztonságos átvitelét tárgyaltuk, és az ismertetett támadások is a statikus esettel foglalkoztak. A bitek váltásakor fellépő tranziens jelenségek alapján viszont Eve számára lehetőség nyílhat az aktuális állapot megismerésére, melynek kiküszöböléséhez az ellenállások kapcsolásakor a feszültségjeleknek nulla értékűnek kell lenniük, és ezután is csak megadott sebességgel növelhetőek. A hardveres implementációk során ezért a jelek rámpázása illetve analóg és digitális sávszűrők alkalmazása szükséges [4, 7, 49, 63].

A KLJN protokoll legújabb feltörési kísérletei a tranziens jelenségeken, illetve a jelek időfüggésén alapulnak. Bennett és Riedel majd Gunn és Abott támadása a vezetéken történő hullámterjedést használja ki [64-68, 8]. A javasolt módszer szerint a (3.5) egyenlet teljesülése, azaz a hullámhossznál rövidebb kábelhossz esetén is kihasználható a hullámterjedés, azonban információszivárgás (vagy teljes feltörhetőség) csak az ideálistól eltérő rendszerek esetén lép fel. Gunn és társai valós rendszer esetén is végeztek méréseket, azonban az eredmények ellentmondónak bizonyultak $[8,68]$.

A legújabb támadási kísérletben a bitátvitel kezdetekor mérhető tranziens jelenség terjedési idejének mérése alapján szerezhet Eve információt a kulcsbit értékéről [63]. Az információszivárgás azonban a Kish által bevezetett legújabb protokoll esetében nem lép fel, melyet a 3.3.4. fejezetben tárgyalunk részletesebben, mivel a rendszer támaszkodik az értekezésben bemutatott eredményekre.

\section{A KLJN alkalmazása és további protokollok}

A KLJN rendszer az előbbiekben ismertetett előnyeiből fakadóan számos területen alkalmazható. A számítástechnikai rendszerek titkosított kommunikációján túl felhasználható különböző hardverkomponensek, ipari szenzorhálózatok, járművek kommunikációs rendszerének, illetve a bankkártyával történő tranzakciók biztonságának területén is [69-72]. A kulcsmegosztás lehetséges okoshálózaton („Smart Griden”) keresztül, illetve egyedi azonosítást elősegítő fizikai eszköz (Physical Unclonable Function, PUF) létrehozására is alkalmas [73, 74].

A KLJN rendszer egy diszkrét idejű kulcsmegosztó protokollt is inspirált, amely, bár nem abszolút biztonságos, az információszivárgás mértéke a kommunikáció sebességének csökkentésével tetszőleges mértékben redukálható [75, 76].

A Kish által javasolt eredeti protokollnak számos változata született, melyek a valós rendszerek esetén fellépő információszivárgás mértékét csökkentik, illetve a kommunikáció sebességét növelhetik [77]. Az értekezés tárgyát képező 3.3. és 3.4. fejezetben bemutatott, általánosított rendszerek a KLJN újabb protokolljainak is tekinthetőek, melyek Kisht legújabb rendszerének bevezetésére inspirálták, így az a 3.3.4. fejezetben kerül bemutatásra. 


\subsubsection{A rendszer vizsgálata a matematikai statisztika eszközeivel}

Mint láthattuk, a KLJN rendszer abszolút biztonságosságának bizonyítása fizikai törvényeken alapszik. A továbbiakban a rendszert egy új megközelítésből, pusztán a valószínűségszámítás és a matematikai statisztika eszközeivel vizsgáljuk, mely során a rendszerről a következőket feltételezzük:

1. Eve ismeri az Alice és Bob által használt ellenállások értékeit és a zajgenerátorok effektív értékeit,

2. Eve által a vezetéken két mennyiség mérhető, mégpedig:

- feszültség $\left(V_{\mathrm{E}}(t)\right)$,

- áramerősség $\left(I_{\mathrm{E}}(t)\right)$.

A továbbiakban a két kommunikáló fél által használt két-két zajgenerátort négy, egymástól független valószínűségi változónak feleltetjük meg ( $\left.V_{\mathrm{LA}}, V_{\mathrm{HA}}, V_{\mathrm{LB}}, V_{\mathrm{HB}}\right)$, az Eve által mérhető két mennyiség $\left(V_{\mathrm{E}}(t)\right.$ és $\left.I_{\mathrm{E}}(t)\right)$ pedig ezen zajgenerátorok által előállított feszültségzajok ( $\left.V_{\mathrm{LA}}(t), V_{\mathrm{HA}}(t), V_{\mathrm{LB}}(t), V_{\mathrm{HB}}(t)\right)$ - a Kirchhoff törvények szerint adódó - lineáris kombinációi. Az ezen mennyiségekhez rendelt valószínűségi változók: $V_{\mathrm{E}}$ és $I_{\mathrm{E}}$.

Fontos megjegyezni, hogy ez utóbbi állítás statikus esetben igaz, azaz a következőkben a tranziens jelenségeket, továbbá a jelek időfüggésén alapuló támadásokat nem vizsgáljuk.

A következőkben használt jelölésrendszer és nevezéktan kapcsán megjegyzendő, továbbá, hogy mivel nulla középértékű feszültségzajok kerülnek felhasználásra, és ebből következően $V_{\mathrm{E}}(t)$ és $I_{\mathrm{E}}(t)$ időbeli átlagértéke is nulla, így ezen mennyiségekre igaz, hogy varianciájuk megegyezik négyzetük időbeli átlagértékével, azaz $\left(V_{\mathrm{LA}}(t)\right.$-t példaként tekintve):

$$
\left\langle V_{\mathrm{LA}}^{2}(t)\right\rangle=\sigma_{\mathrm{LA}}^{2} .
$$

Továbbá, egy zajgenerátor effektív értéke megegyezik az előállított feszültségzaj szórásával, azaz $V_{\mathrm{LA}, \mathrm{eff}}=\sigma_{\mathrm{LA}}$.

\subsection{Az abszolút biztonságosság zajra vonatkozó feltételei}

A KLJN protokoll ötlete a kommunikáló felek által használt ellenállások egymástól független hőmérsékleti zajának kiaknázásán alapszik, továbbá a gyakorlati alkalmazáshoz szükséges jelerősség eléréséhez alkalmazott zajgenerátorok is Johnson-típusú zajokat emulálnak, így az abszolút biztonságosság klasszikus fizikai bizonyítása továbbra is érvényes. Azonban, tekintettel arra, hogy mesterséges zajgenerátorokat használunk, felmerülhet a kérdés, lehetséges-e más típusú zajok alkalmazása, és ha igen, milyen feltételekkel? 
Ez a megközelítés, melyet Gingl Zoltán és Mingesz Róbert alkalmazott először 2014-ben [78], bizonyos tekintetben ellentétes az addigiakkal, hiszen nem adott zajparaméterek esetén vizsgálták a rendszer biztonságosságát, hanem arra keresték a választ, hogy az abszolút biztonság milyen zajparaméterek mellett áll fent.

A biztonságosság szükséges feltételeit a rendszer a 3.1.3. fejezetben ismertetett, statisztikai megközelítésével vizsgálták, a négy független valószínűségi változóval leírható zajgenerátor elnevezése a 3.3. ábrán látható.

\section{Alice Bob}

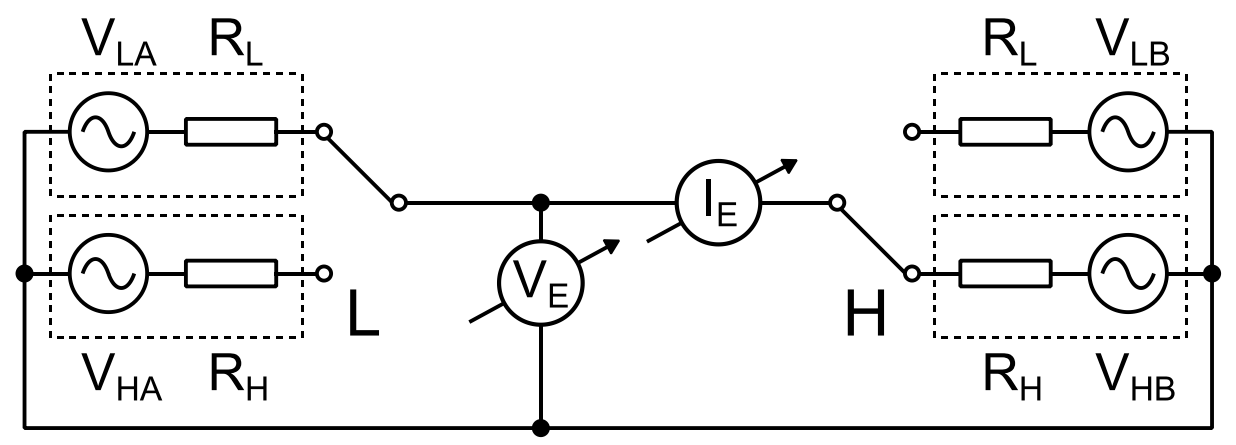

3.3. ábra: A KLJN rendszer modellje ( $\mathrm{LH}$ állapotban), jelölve a négy független valószínűségi változóval jellemzett zajgenerátorokat.

Az Eve által mérhető két mennyiséget, azaz a $V_{\mathrm{E}}(t)$ feszültséget és az $I_{\mathrm{E}}(t)$ áramerősséget a 3.3. ábrán látható jelölésekkel az alábbi egyenletek adják meg LH és HL esetben:

$$
\begin{aligned}
& V_{\mathrm{E}, \mathrm{LH}}(t)=\frac{V_{\mathrm{LA}}(t) \cdot R_{\mathrm{H}}+V_{\mathrm{HB}}(t) \cdot R_{\mathrm{L}}}{R_{\mathrm{L}}+R_{\mathrm{H}}}, \\
& I_{\mathrm{E}, \mathrm{LH}}(t)=\frac{V_{\mathrm{HB}}(t)-V_{\mathrm{LA}}(t)}{R_{\mathrm{L}}+R_{\mathrm{H}}}, \\
& V_{\mathrm{E}, \mathrm{HL}}(t)=\frac{V_{\mathrm{HA}}(t) \cdot R_{\mathrm{L}}+V_{\mathrm{LB}}(t) \cdot R_{\mathrm{H}}}{R_{\mathrm{L}}+R_{\mathrm{H}}}, \\
& I_{\mathrm{E}, \mathrm{HL}}(t)=\frac{V_{\mathrm{LB}}(t)-V_{\mathrm{HA}}(t)}{R_{\mathrm{L}}+R_{\mathrm{H}}} .
\end{aligned}
$$

Az Eve által mért két mennyiség szórásának HL és LH esetben meg kell egyeznie, különben a két eset megkülönböztethető, azaz a kommunikáció feltörhető. Eve a zajgenerátorok effektív értékeinek, az ellenállások értékeinek, illetve a vezetéken mért értékek ismeretében megvizsgálhatja azt a feltevést, hogy LH esetben van a rendszer, és ennek ellenkezőjét is. Ha nem megfelelő a zajgenerátorok effektív értékének skálázása, Eve a hibás hipotézise esetén más értéket fog kapni valamelyik kommunikáló fél zajgenerátorainak paraméterére, mint ami ismert, azaz rájön a 
helyes állapotra. Ezek alapján Gingl és Mingesz megmutatta, hogy a zajgenerátorok effektív értékének, azaz a feszültségzajok szórásának alábbi skálázása az abszolút biztonságosság szükséges feltétele [78]:

$$
\frac{\sigma_{\mathrm{H}}}{\sigma_{\mathrm{L}}}=\sqrt{\frac{R_{\mathrm{H}}}{R_{\mathrm{L}}}},
$$

ahol $\sigma_{\mathrm{H}}$ és $\sigma_{\mathrm{L}}$ a H és L állású kapcsolónál lévő feszültségzaj szórása.

Az előbbi összefüggés megfogalmazható úgy is, hogy a feszültségzajok varianciájának az ellenállásokkal arányosan kell skálázódnia:

$$
\frac{\left\langle V_{\mathrm{H}}^{2}(t)\right\rangle}{\left\langle V_{\mathrm{L}}^{2}(t)\right\rangle}=\frac{R_{\mathrm{H}}}{R_{\mathrm{L}}} .
$$

Látható, hogy az eredmény megegyezik a (3.1)-(3.4) egyenletekből, azaz a termikus zaj teljesítménysűrűség-spektrumából következő skálázással.

Megjegyzendő, hogy e skálázási feltétel nem szabja meg az LH és HL esetben használt zajgenerátárok effektív értékeinek egymáshoz való viszonyát. Az ellenállások termikus zaját alapul véve az ellenáspárok értékének azonosságából adódik a zajgenerátor-párok effektív értékének egyenlősége, így ezt Gingl és Mingesz nem vizsgálta, azonban, ha a fejezet elején megfogalmazott módon arra keressük a választ, hogy milyen zajok esetén biztonságos a rendszer, ez nem szükségszerủ megkötés. Ugyanakkor az Eve által mérhető áram varianciájának meg kell egyeznie LH és HL esetben, azaz a (3.8) és (3.10) egyenletek alapján:

$$
\left\langle I_{\mathrm{E}, \mathrm{LH}}^{2}(t)\right\rangle=\left\langle I_{\mathrm{E}, \mathrm{HL}}^{2}(t)\right\rangle \Rightarrow \frac{\left\langle V_{\mathrm{LA}}^{2}(t)\right\rangle+\left\langle V_{\mathrm{HB}}^{2}(t)\right\rangle}{\left(R_{\mathrm{L}}+R_{\mathrm{H}}\right)^{2}}=\frac{\left\langle V_{\mathrm{HA}}^{2}(t)\right\rangle+\left\langle V_{\mathrm{LB}}^{2}(t)\right\rangle}{\left(R_{\mathrm{H}}+R_{\mathrm{L}}\right)^{2}},
$$

ebből pedig a (3.12) feltétel alapján következik, hogy $\sigma_{\mathrm{H}}=\sigma_{\mathrm{HA}}=\sigma_{\mathrm{HB}}$ és $\sigma_{\mathrm{L}}=\sigma_{\mathrm{LA}}=\sigma_{\mathrm{LB}}$.

A zajok eloszlására vonatkozó kritériumot is az előbbiekhez hasonló módon határozták meg; a vezetéken mért feszültség- és áramzaj sűrűségfüggvényéből Eve visszaszámolhatja valamelyik kommunikáló fél által a vezetékre kapcsolt feszültségzajt mind a helyes, mind a hibás feltételezés esetén. E sűrűségfüggvény a két fél által használt zajok lineáris kombinációjaként adódik, és a hibás állapot feltételezése esetén csak abban az esetben egyezik meg a feszültséggenerátorok által elóállított zajok - a Kerckhoff-elvnek megfelelően publikus - sűrüségfüggvényével, ha azokra igaz a (2.32) egyenlettel megadott stabilitási feltétel. Mint a 2.1.1. fejezetben láttuk, ennek a kritériumnak megfelel minden stabilis eloszlás, azonban ezek közül csak a normális eloszlás szórása véges, így a gyakorlati szempontokat is figyelembe véve a biztonságosság szükséges feltétele - ugyancsak az ellenállások hőmérsékleti zajának megfelelően - a normális eloszlás. 
A zajok paramétereire vonatkozóan tehát ismert két, a klasszikus fizikai megközelítésnek megfelelő feltétel, melyek teljesülése szükséges az abszolút biztonságos kommunikáció megvalósításához. Felmerülhet azonban az igény, hogy Kish eredeti, termodinamikai megfontolásokon [21] nyugvó bizonyításához hasonlóan matematikai eszközökkel is bizonyítsuk, hogy léteznek feltételek, melyek elégségesek, azaz további körülmények ismerete nélkül állíthassuk, hogy a rendszer abszolút biztonságos.

Ehhez a két mennyiség statisztikai vizsgálatán túl azok kapcsolatának, azaz az együttes valószínűség-eloszlásának általános leírása szükséges, hiszen az abszolút biztonságos kommunikációhoz LH és HL állapotban a feszültség és áramerősség együttes eloszlásához tartozó valószínűségi sűrűségfüggvényeknek $\left(h_{\mathrm{LH}}\left(I_{\mathrm{E}}, V_{\mathrm{E}}\right)\right.$ és $\left.h_{\mathrm{HL}}\left(I_{\mathrm{E}}, V_{\mathrm{E}}\right)\right)$ is meg kell egyeznie.

Első célkitűzésem ez alapján a KLJN protokoll matematikai vizsgálatának az Eve által mérhető két mennyiség együttes eloszlásának tanulmányozásával való kiegészítése volt.

\subsubsection{A zajparaméterek hatásának numerikus vizsgálata}

Az Eve által mérhető $V_{\mathrm{E}}(t)$ feszültség és $I_{\mathrm{E}}(t)$ áramerősség együttes eloszlásának vizsgálatához numerikus szimulációkat készítettem LabVIEW környezetben, melyek letölthetőek, továbbá az eredményeket videókkal is illusztráltam [79]. A különböző eloszlású és szórású feszültségzajokat megfelelő véletlenszámgenerátorokkal generáltam, melyekből a (3.7)-(3.10) egyenletek segítsével előállítható $V_{\mathrm{E}}(t)$ és $I_{\mathrm{E}}(t)$. E két mennyiség szórásdiagramja (lásd 2.1.2. fejezet) LH és HL állapotban lehetőséget nyújt a két mennyiség közötti kapcsolat vizuális szemléltetésére. Egy bit átvitelét, azaz egy LH vagy HL állapotot az együttes eloszlások alakjának vizsgálatához a gyakorlati megvalósításhoz szükséges adatmennyiségnél jelentősen nagyobb, $2^{13}$ hosszúságú véletlenszámsorozatokkal vizsgáltam [49].

A zajgenerátorok skálázásának hatása jól megfigyelhető a 3.4. és 3.5. ábrán, melyeken normális eloszlású zajok felhasználásával látható egy LH és egy HL állapotban szimulált adatsor szórásdiagramja. A 3.4. ábrán a zajgenerátorok effektív értékeinek aránya nem teljesíti a (3.11) egyenletben foglalt feltételt, míg a 3.5. ábra esetében igen (a paraméterek az ábrafeliratokban olvashatóak).

Jól látható, hogy nem megfelelő skálázás esetén a szóródási képek egyértelműen különbözőek, azaz az LH és HL állapotok Eve számára megkülönböztethetőek. A szóródási képekre felrajzolható ellipszisek a két állapotban egymás $V_{\mathrm{E}}$ tengelyre vett tükörképei. Ez a (3.7)-(3.10) egyenletek alapján könnyen értelmezhető, hiszen ha ugyanazt az alacsony és magas effektív értéknek megfelelő véletlenszámsort alkalmazzuk a szimulációban a két állapotban, akkor $V_{\mathrm{E}}(t)$ megegyezik a két esetben, míg $I_{\mathrm{E}}(t)$ értéke HL esetben az LH állapotban adódó érték negáltja lesz. Az alábbi 
ábrákon a valós esetnek, azaz négy független feszültségzajnak megfelelően különböző véletlenszámsorok lettek felhasználva mind a négy zajgenerátor esetében. Látható továbbá a 3.4. ábrán, hogy az ellipszis főtengelyei nem esnek egybe a koordinátarendszer tengelyeivel, azaz a 2.1.2. fejezetben ismertettek alapján a két mennyiség nem független.
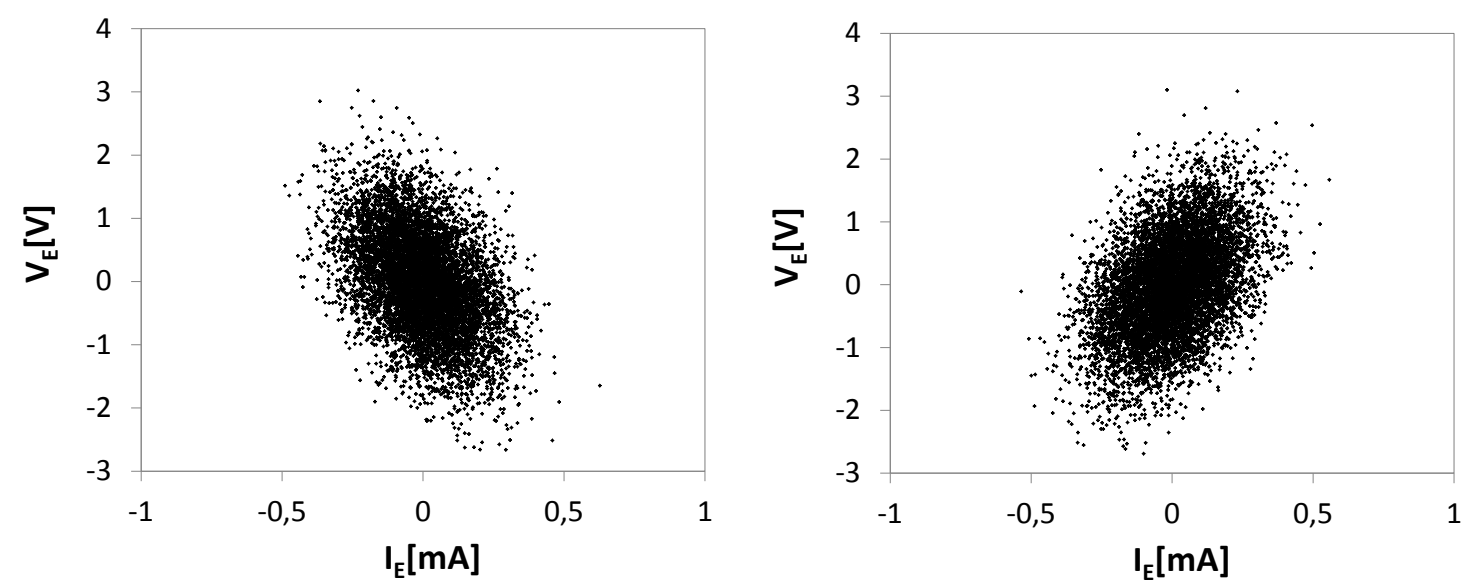

3.4. ábra: Az Eve által mérhető két mennyiség szórásdiagramja LH állapotban (bal oldalon) és HL állapotban (jobb oldalon) normális eloszlású feszültségzajok esetén, ha a (3.11) egyenletben foglalt feltétel nem teljesül. $R_{\mathrm{L}}=1 \mathrm{k} \Omega, R_{\mathrm{H}}=10 \mathrm{k} \Omega, \sigma_{\mathrm{H}}=1,5 \mathrm{~V}$, $\sigma_{\mathrm{L}}=1 \mathrm{~V}$, azaz $\sigma_{\mathrm{H}} / \sigma_{\mathrm{L}}=1,5$.
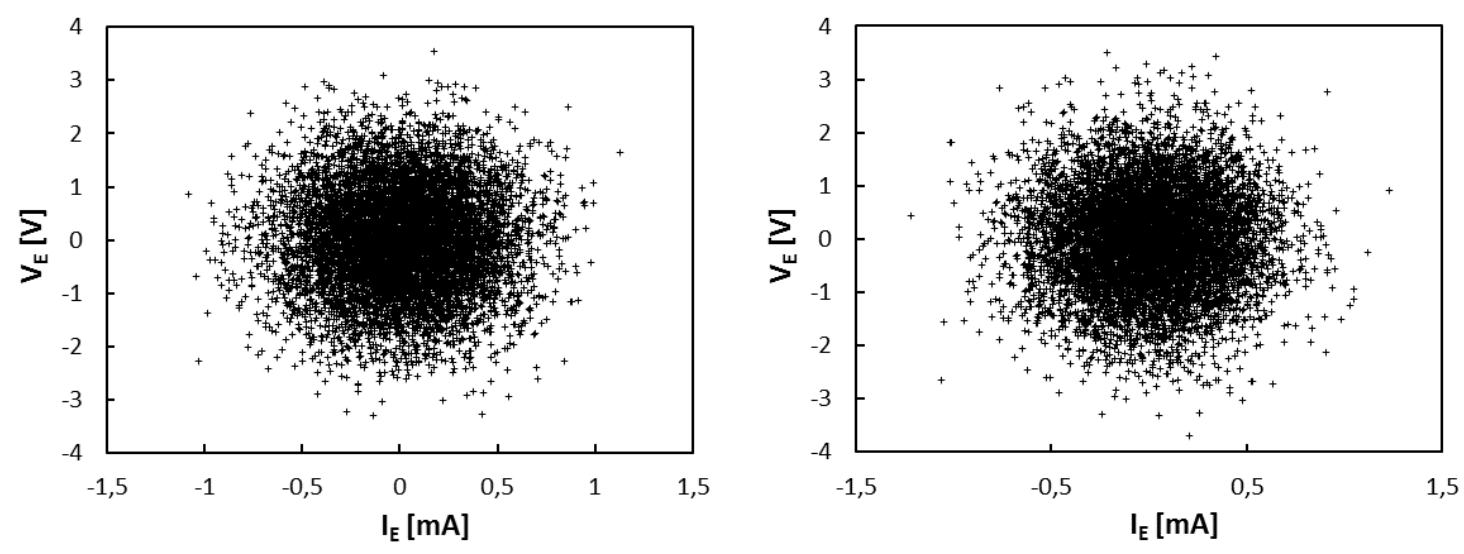

3.5. ábra: Az Eve által mérhető két mennyiség szórásdiagramja LH állapotban (bal oldalon) és HL állapotban (jobb oldalon) normális eloszlású feszültségzajok esetén, ha a (3.11) egyenletben foglalt feltétel teljesül. $R_{\mathrm{L}}=1 \mathrm{k} \Omega, R_{\mathrm{H}}=10 \mathrm{k} \Omega, \sigma_{\mathrm{H}}=3,33 \mathrm{~V}, \sigma_{\mathrm{L}}=1 \mathrm{~V}$, $\operatorname{azaz} \sigma_{\mathrm{H}} / \sigma_{\mathrm{L}}=\left(R_{\mathrm{H}} / R_{\mathrm{L}}\right)^{1 / 2}$.

Ahogyan a 3.5. ábrán látható, amennyiben a (3.11) egyenletben foglalt feltétel teljesül, a két szórásdiagram nem megkülönböztethető, továbbá az ellipszisek főtengelyei egybeesnek a koordinátarendszer tengelyeivel, azaz a két mennyiség független. E megfigyelések a szimulált adatsorok esetén számolt korreláció és szórásdiagramokkra illesztett egyenesek meredeksége alapján meghatározott regressziós együttható meghatározásával is alátámaszthatóak (melyek közötti 
kapcsolatot a (2.51) egyenlet adja meg). E paraméterek a 3.4. ábra esetén az LH és HL esetben különböző értékűnek (közelítőleg egymás negáltjának), míg a 3.5. esetben nullának adódtak.

A feszültségzajok eloszlásának vizsgálatához más típusú eloszlásokat is megvizsgáltam, a (3.11) egyenlet szerinti skálafeltételt kielégítő szórásérték esetében. A 3.6. ábrán szimmetrikus stabilis eloszlás (lásd 2.1.1. fejezet) esetén látható a szórásdiagram, különböző $\alpha$ stabilitási paraméterek esetén, HL esetben.
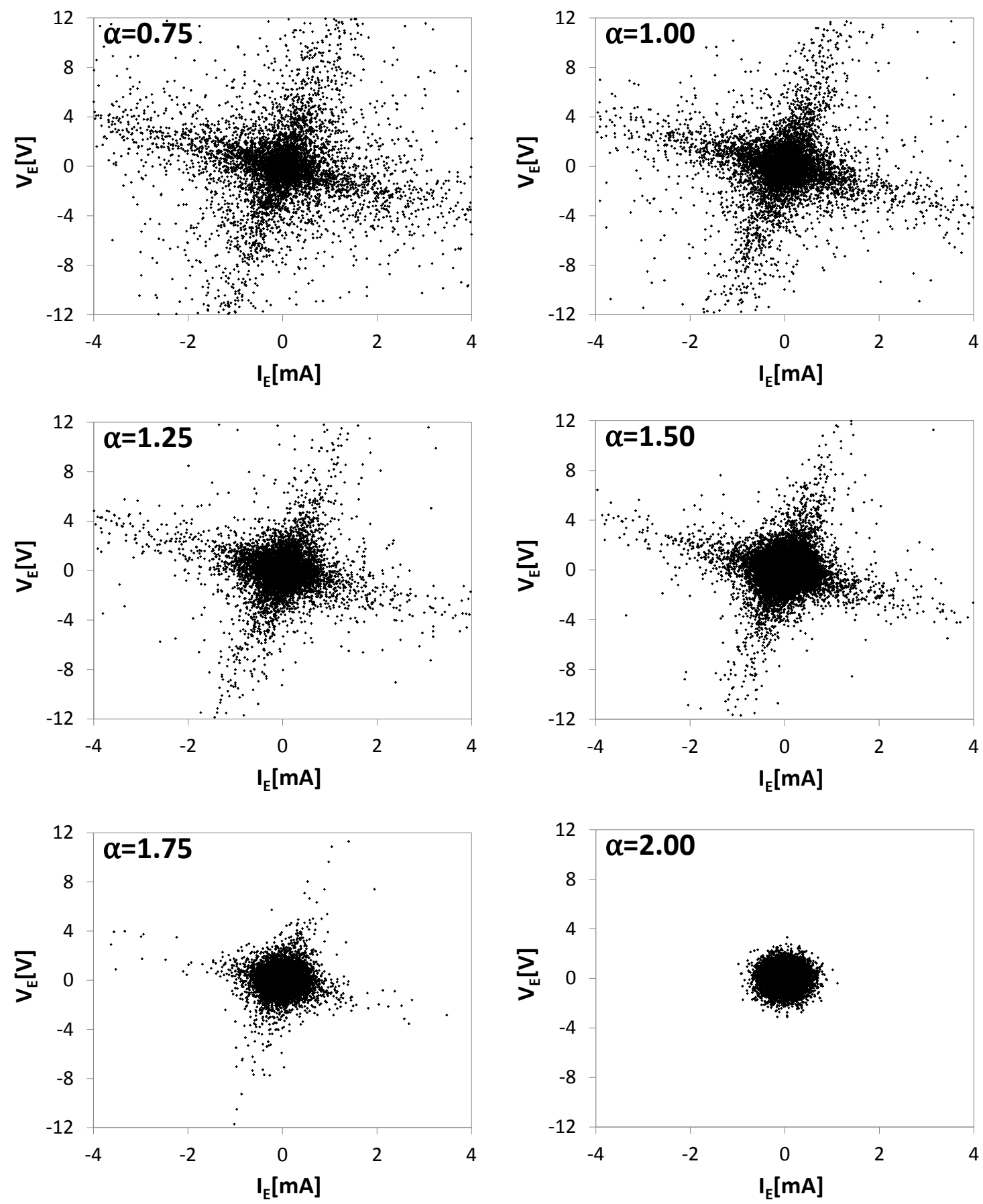

3.6. ábra: Az Eve által mérhető két mennyiség szórásdiagramja HL esetben, stabilis eloszlások esetén, különböző $\alpha$ stabilitási értékekre. $\alpha=1$ a Cauchy-, $\alpha=2$ pedig a normális eloszlás. $R_{\mathrm{L}}=1 \mathrm{k} \Omega, R_{\mathrm{H}}=10 \mathrm{k} \Omega, w_{\mathrm{H}} / w_{\mathrm{L}}=\left(R_{\mathrm{H}} / R_{\mathrm{L}}\right)^{1 / 2}$ 
Mivel a szórás stabilis eloszlások esetén a normális eloszlás kivételével nem véges, a zajgenerátorok effektív értékét a (2.36) karakterisztikus egyenletben szereplő $w$ skálaparaméter segítségével állítottam be. Jól látható, hogy bár a feszültségzajok effektív értékének skálázása helyes, továbbá a korreláció és a lineáris regressziós paraméter értéke is nullának adódott, a szóródási kép mégis aszimmetrikus (kivéve az $\alpha=2$ esetet). A 3.4. ábránál említetteknek megfelelően mivel a (3.7)-(3.10) egyenletek alapján ugyanazt az alacsony és magas effektív értéknek megfelelő véletlenszámsort alkalmazva a szóródási kép HL állapot az LH állapot esetében kapott tükörképe lesz - a két állapot megkülönböztethető minden $\alpha$ esetén, kivéve az $\alpha=2$ esetben, amely az imént tárgyalt normális eloszlás (lásd 2.1.1. fejezet). Ezek alapján a stabilis eloszlás önmagában nem elég a biztonságossághoz, ezt a nem véges szórás értéken túlmenően az $V_{\mathrm{E}}$ és $I_{\mathrm{E}}$ együttes eloszlásának aszimmetrája is megmutatta.

A KLJN protokoll digitális implementációja során a feszültségzajokat véletlenszám-generátorok felhasználásával állítják elő [49]. A pszeudovéletlenszámgenerátorokkal elsőként egyenletes eloszlású zaj állítható elő, ezekből további műveletek elvégzésével lehetséges normális eloszlású véletlen számsorozat előállítása. A 3.7. ábrán egyenletes eloszlású feszültségzajok felhasználásával generált szórásdiagramok láthatóak, a skálázási feltételnek megfelelő effektív értékű zajgenerátorok esetén. Bár a korreláció ezesetben is nullának adódott, a szóródási kép aszimmetrikus, azaz a két állapot megkülönböztethető.
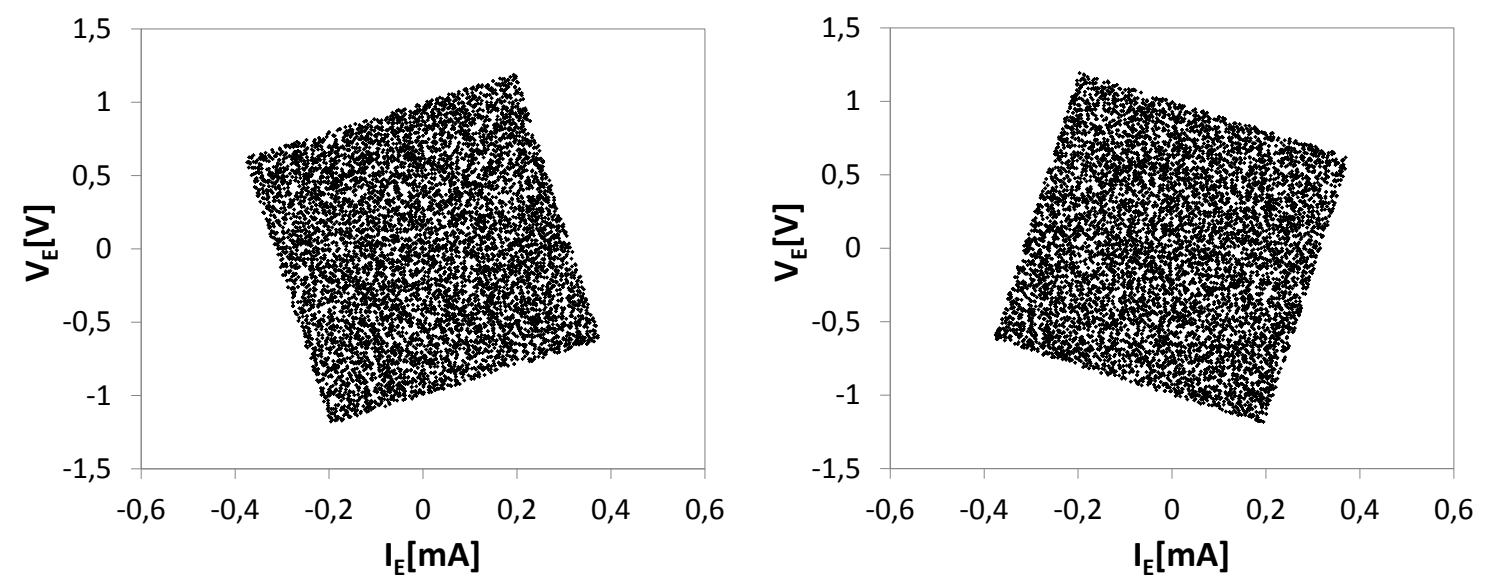

3.7. ábra: Az Eve által mérhető két mennyiség szórásdiagramja LH (bal oldalon) és HL (jobb oldalon) esetben, egyenletes eloszlású feszültségzajok esetén. $R_{\mathrm{L}}=1 \mathrm{k} \Omega$, $R_{\mathrm{H}}=10 \mathrm{k} \Omega, \sigma_{\mathrm{H}} / \sigma_{\mathrm{L}}=\left(R_{\mathrm{H}} / R_{\mathrm{L}}\right)^{1 / 2}$

Mint láthattuk, $V_{\mathrm{E}}$ és $I_{\mathrm{E}}$ együttes eloszlásának vizsgálata alátámasztotta az eddig ismert, biztonságosságra vonatkozó szükséges feltételeket. A normális eloszlástól eltérő valószínűség-eloszlások esetében, bár helyes skálázás esetén nulla a korreláció és a lineáris regresszió értéke, mégsem független a két mennyiség, egymásra 
vonatkoztatott regressziójuk nemlineáris, mely összehangban van a 2.1.2. fejezetben ismertetettekkel, és jól mutatja a normális eloszlás kitüntetett szerepét.

\subsubsection{A zajparaméterekre vonatkozó követelmények bizonyítása}

Mivel Eve által csak $V_{\mathrm{E}}(t)$ és $I_{\mathrm{E}}(t)$ mérhető, amennyiben a két mennyiség statisztikai paraméterein túl azok együttes eloszlása is megegyezik LH és HL állapotban, a kommunikáció abszolút biztonságos. A mennyiségekhez rendelt valószínűségi változók sűrűségfüggvényével és együttes sűrűségfüggvényével megfogalmazva a rendszer abszolút biztonságos, ha az alábbi három feltétel teljesül:

1. $p_{\mathrm{LH}}\left(I_{\mathrm{E}}\right)=p_{\mathrm{HL}}\left(I_{\mathrm{E}}\right)$,

2. $p_{\mathrm{LH}}\left(V_{\mathrm{E}}\right)=p_{\mathrm{HL}}\left(V_{\mathrm{E}}\right)$,

3. $h_{\mathrm{LH}}\left(I_{\mathrm{E}}, V_{\mathrm{E}}\right)=h_{\mathrm{HL}}\left(I_{\mathrm{E}}, V_{\mathrm{E}}\right)$.

Mint láttuk, az első két feltétel az eddigiekben vizsgált két, zajparaméterekre vonatkozó feltétel kielégülése esetén teljesül [78]. Amennyiben ezen túlmenően $V_{\mathrm{E}}$ és $I_{\mathrm{E}}$ független, a harmadik feltétel is magától értetődően biztosított. Ez a kitétel összhangban van Kish a KLJN-re vonatkozó, termikus egyensúlyt kihasználó bizonyításával [21,48].

Mivel a zajgenerátoroknak megfeleltetett valószínűségi változók függetlenek, $V_{\mathrm{E}}$ és $I_{\mathrm{E}}$ pedig ezek lineáris kombinációi, kihasználhatjuk a 2.1.2. fejezetben ismertetett tételt [35]. A (2.52) és (2.53) összefüggések alapján, $\xi_{1}$ és $\xi_{2}$ független változók $Y_{\mathrm{A}}$ és $Y_{\mathrm{B}}$ lineáris kombinációi akkor és csak akkor függetlenek, ha $\xi_{1}$ és $\xi_{2}$ normális eloszlású, és a (3.15) összefüggés fennáll:

$$
\begin{aligned}
& Y_{\mathrm{A}}=A_{1} \cdot \xi_{1}+A_{2} \cdot \xi_{2} \text { és } Y_{\mathrm{B}}=B_{1} \cdot \xi_{1}+B_{2} \cdot \xi_{2}, \\
& A_{1} \cdot B_{1} \cdot \sigma_{1}^{2}+A_{2} \cdot B_{2} \cdot \sigma_{2}^{2}=0,
\end{aligned}
$$

ahol $\sigma_{1}$ és $\sigma_{2}$ az $\xi_{1}$ és $\xi_{2}$ változók szórásai.

Felhasználva a KLJN rendszerre felírt (3.7)-(3.10) egyenletrendszert, LH állapotban:

$$
\begin{aligned}
& V_{\mathrm{E}, \mathrm{LH}}(t)=\frac{R_{\mathrm{H}}}{R_{\mathrm{L}}+R_{\mathrm{H}}} V_{\mathrm{LA}}(t)+\frac{R_{\mathrm{L}}}{R_{\mathrm{L}}+R_{\mathrm{H}}} V_{\mathrm{HB}}(t), \\
& I_{\mathrm{E}, \mathrm{HL}}(t)=-\frac{1}{R_{\mathrm{L}}+R_{\mathrm{H}}} V_{\mathrm{LA}}(t)+\frac{1}{R_{\mathrm{L}}+R_{\mathrm{H}}} V_{\mathrm{HB}}(t),
\end{aligned}
$$

így a (3.15) egyenlet alapján $V_{\mathrm{E}}$ és $I_{\mathrm{E}}$ függetlenségének feltétele:

$$
\frac{R_{\mathrm{H}}}{R_{\mathrm{L}}+R_{\mathrm{H}}} \cdot\left(-\frac{1}{R_{\mathrm{L}}+R_{\mathrm{H}}}\right) \cdot \sigma_{\mathrm{LA}}^{2}+\frac{R_{\mathrm{L}}}{R_{\mathrm{L}}+R_{\mathrm{H}}} \cdot \frac{1}{R_{\mathrm{L}}+R_{\mathrm{H}}} \cdot \sigma_{\mathrm{HB}}^{2}=0,
$$

tovább egyszerűsítve: 


$$
-R_{\mathrm{H}} \cdot \sigma_{\mathrm{LA}}^{2}+R_{\mathrm{L}} \cdot \sigma_{\mathrm{HB}}^{2}=0 .
$$

HL állapotban hasonló módon járhatunk el:

$$
\begin{aligned}
& V_{\mathrm{E}, \mathrm{HL}}(t)=\frac{R_{\mathrm{L}}}{R_{\mathrm{L}}+R_{\mathrm{H}}} V_{\mathrm{HA}}(t)+\frac{R_{\mathrm{H}}}{R_{\mathrm{L}}+R_{\mathrm{H}}} V_{\mathrm{LB}}(t), \\
& I_{\mathrm{E}, \mathrm{HL}}(t)=-\frac{1}{R_{\mathrm{L}}+R_{\mathrm{H}}} V_{\mathrm{HA}}(t)+\frac{1}{R_{\mathrm{L}}+R_{\mathrm{H}}} V_{\mathrm{LB}}(t),
\end{aligned}
$$

így a (3.15) egyenlet alapján $V_{\mathrm{E}}$ és $I_{\mathrm{E}}$ függetlenségének feltétele:

$$
\frac{R_{\mathrm{L}}}{R_{\mathrm{L}}+R_{\mathrm{H}}} \cdot\left(-\frac{1}{R_{\mathrm{L}}+R_{\mathrm{H}}}\right) \cdot \sigma_{\mathrm{HA}}^{2}+\frac{R_{\mathrm{H}}}{R_{\mathrm{L}}+R_{\mathrm{H}}} \cdot \frac{1}{R_{\mathrm{L}}+R_{\mathrm{H}}} \cdot \sigma_{\mathrm{LB}}^{2}=0,
$$

tovább egyszerűsítve:

$$
-R_{\mathrm{L}} \cdot \sigma_{\mathrm{HA}}^{2}+R_{\mathrm{H}} \cdot \sigma_{\mathrm{LB}}^{2}=0 .
$$

A (3.19) és (3.23) egyenletből következően tehát $V_{E}$ és $I_{E}$ függetlenségének feltétele:

$$
\frac{\sigma_{\mathrm{HB}}}{\sigma_{\mathrm{LA}}}=\frac{\sigma_{\mathrm{HA}}}{\sigma_{\mathrm{LB}}}=\frac{\sigma_{\mathrm{H}}}{\sigma_{\mathrm{L}}}=\sqrt{\frac{R_{\mathrm{H}}}{R_{\mathrm{L}}}},
$$

azaz

$$
\frac{\left\langle V_{\mathrm{HB}}^{2}(t)\right\rangle}{\left\langle V_{\mathrm{LA}}^{2}(t)\right\rangle}=\frac{\left\langle V_{\mathrm{HA}}^{2}(t)\right\rangle}{\left\langle V_{\mathrm{LB}}^{2}(t)\right\rangle}=\frac{\left\langle V_{\mathrm{H}}^{2}(t)\right\rangle}{\left\langle V_{\mathrm{L}}^{2}(t)\right\rangle}=\frac{R_{\mathrm{H}}}{R_{\mathrm{L}}} .
$$

Tehát $V_{\mathrm{E}}$ és IE akkor és csak akkor független, ha a feszültségzajok normális eloszlásúak és a (3.24) egyenlet alapján megadott skálázási feltétel teljesül. Másszóval bizonyítottuk, hogy e két feltétel az abszolút biztonságosság szükséges és elégséges feltétele. Ezzel a KLJN protokoll abszolút biztonságosságának klasszikus fizikai megfontolásokat mellőző, de azokkal összhangban álló matematikai alapú bizonyítását is megadtuk.

A 3.2. fejezetben bemutatott eredményeket az értekezés 1. tézispontja foglalja össze.

\subsection{A KLJN kulcsmegosztó protokoll általánosítása}

Az előző fejezetben $h_{\mathrm{LH}}\left(I_{\mathrm{E}}, V_{\mathrm{E}}\right)$ és $h_{\mathrm{HL}}\left(I_{\mathrm{E}}, V_{\mathrm{E}}\right)$ egyenlőségének biztosításához azt használtuk ki, hogy $V_{\mathrm{E}}$ és $I_{\mathrm{E}}$ függetlensége azt egyértelműen garantálja. Normális eloszlású feszültségzajok esetén azok lineáris kombinációi, tehát $V_{\mathrm{E}}$ és $I_{\mathrm{E}}$ is normális eloszlású, így ez esetben azok függetlenségének megkötése egyenlő azzal, hogy a korrelációjuk nulla legyen, mely összehangban van a probléma termodinamikai 
megközelítésével [48]. Azonban a 3.1.3. fejezet szerinti megközelítésben, illetve a 3.2.2. fejezetben ismertetett három, biztonságosságra vonatkozó kritérium alapján mivel normális eloszlású feszültségzajok esetén $V_{\mathrm{E}}$ és $I_{\mathrm{E}}$ függőségét a korreláció teljes mértékben meghatározza - az is elegendő, ha a korreláció nem nulla, de azonos LH és HL esetben, hiszen ekkor Eve nem tud különbséget tenni a két állapot között.

Ez alapján, a 3.2.2. fejezetben meghatározott, abszolút biztonságossághoz tartozó három kritérium normális eloszlású zajokat feltételezve felírható az alábbi módon is:

1. $\left\langle I_{\mathrm{E}, \mathrm{LH}}^{2}(t)\right\rangle=\left\langle I_{\mathrm{E}, \mathrm{HL}}^{2}(t)\right\rangle$,

2. $\left\langle V_{\mathrm{E}, \mathrm{LH}}^{2}(t)\right\rangle=\left\langle V_{\mathrm{E}, \mathrm{HL}}^{2}(t)\right\rangle$,

3. $\left\langle I_{\mathrm{E}, \mathrm{LH}}(t) V_{\mathrm{E}, \mathrm{LH}}(t)\right\rangle=\left\langle I_{\mathrm{E}, \mathrm{HL}}(t) V_{\mathrm{E}, \mathrm{HL}}(t)\right\rangle$.

Mint láttuk, az első két kritériumnak megfelelő zajparaméterek esetén a korreláció LH és HL esetben nullának adódott, így vizsgáljunk meg egy általánosabb rendszert.

\subsubsection{Az általánosított rendszer}

Az eredeti protokoll szerint Alice és Bob azonos ellenálláspárral rendelkeznek, és a szimmetrikus elrendezésből adódóan azonos effektív értékű zajgenerátor-párt használnak. Általánosítsuk a rendszert a 3.8. ábrán látható módon úgy, hogy a két kommunikáló fél tetszőleges ellenálláspárt használhat, mely négy különböző értékű ellenálláshoz négy különböző effektív értékű zajgenerátort kapcsolnak. A kulcscseréhez használt ellenálláspárokat tehát egymástól függetlenül választhatja meg Alice és Bob. Az ellenállások értékére az egyetlen megkötés, ahogyan az eredeti KLJN rendszer esetében is, hogy az L és $H$ állapotnak megfelelően az egy oldalon lévő ellenálláspár két eleme nem lehet egyenlő ( $\left.R_{\mathrm{LA}} \neq R_{\mathrm{HA}}, R_{\mathrm{LB}} \neq R_{\mathrm{HB}}\right)$, mely természetesen csak elméleti szempontból jelent valódi megszorítást.

Alice

Bob

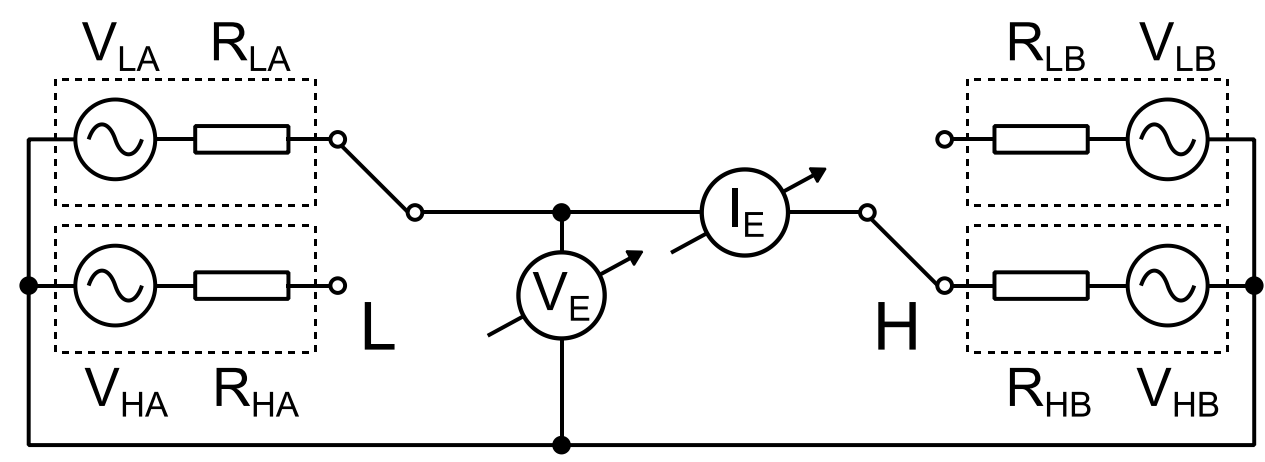

3.8. ábra: Az általánosított KLJN rendszer modellje (LH állapotban), négy különböző értékű ellenállás és effektív értékű zajgenerátor felhasználásával. 
A négy zajgenerátorhoz a 3.2. fejezetben bemutatottakhoz hasonlóan négy valószínűségi változót rendelünk, melyek lineáris kombinációjaként a Kirchhofftörvények segítségével felírhatjuk a vezetéken mérhető feszültséget $\left(V_{\mathrm{E}}(\mathrm{t})\right)$ és áramerősséget $\left(I_{E}(t)\right)$ LH és HL esetben:

$$
\begin{aligned}
& V_{\mathrm{E}, \mathrm{LH}}(t)=\frac{R_{\mathrm{HB}} V_{\mathrm{LA}}(t)+R_{\mathrm{LA}} V_{\mathrm{HB}}(t)}{R_{\mathrm{LA}}+R_{\mathrm{HB}}}, \\
& I_{\mathrm{E}, \mathrm{LH}}(t)=\frac{V_{\mathrm{HB}}(t)-V_{\mathrm{LA}}(t)}{R_{\mathrm{LA}}+R_{\mathrm{HB}}}, \\
& V_{\mathrm{E}, \mathrm{HL}}(t)=\frac{R_{\mathrm{LB}} V_{\mathrm{HA}}(t)+R_{\mathrm{HA}} V_{\mathrm{LB}}(t)}{R_{\mathrm{HA}}+R_{\mathrm{LB}}}, \\
& I_{\mathrm{E}, \mathrm{HL}}(t)=\frac{V_{\mathrm{LB}}(t)-V_{\mathrm{HA}}(t)}{R_{\mathrm{HA}}+R_{\mathrm{LB}}} .
\end{aligned}
$$

\subsubsection{Az abszolút biztonságosság zajra vonatkozó feltételei}

A (3.26)-(3.29) egyenletek alapján a 3.3. fejezet elején megfogalmazott három kritériumban foglalt egyenlőségek felírhatóak a feszültségzajok varianciáival.

Az LH és HL állapotban mérhető áramerősség varianciájának alábbi egyenlősége

$$
\left\langle I_{\mathrm{E}, \mathrm{LH}}^{2}(t)\right\rangle=\left\langle I_{\mathrm{E}, \mathrm{HL}}^{2}(t)\right\rangle
$$

tovább írható a következő alakba:

$$
\frac{\left\langle V_{\mathrm{LA}}^{2}(t)\right\rangle+\left\langle V_{\mathrm{HB}}^{2}(t)\right\rangle}{\left(R_{\mathrm{LA}}+R_{\mathrm{HB}}\right)^{2}}=\frac{\left\langle V_{\mathrm{HA}}^{2}(t)\right\rangle+\left\langle V_{\mathrm{LB}}^{2}(t)\right\rangle}{\left(R_{\mathrm{HA}}+R_{\mathrm{LB}}\right)^{2}} .
$$

Hasonló módon az Eve által a két állapotban mérhető feszültségek varianciájának egyenlősége is kifejezhető a feszültségzajok varianciái és az ellenállásértékek segítségével:

$$
\begin{aligned}
& \left\langle V_{\mathrm{E}, \mathrm{LH}}^{2}(t)\right\rangle=\left\langle V_{\mathrm{E}, \mathrm{HL}}^{2}(t)\right\rangle, \\
& \frac{R_{\mathrm{HB}}^{2}\left\langle V_{\mathrm{LA}}^{2}(t)\right\rangle+R_{\mathrm{LA}}^{2}\left\langle V_{\mathrm{HB}}^{2}(t)\right\rangle}{\left(R_{\mathrm{LA}}+R_{\mathrm{HB}}\right)^{2}}=\frac{R_{\mathrm{LB}}^{2}\left\langle V_{\mathrm{HA}}^{2}(t)\right\rangle+R_{\mathrm{HA}}^{2}\left\langle V_{\mathrm{LB}}^{2}(t)\right\rangle}{\left(R_{\mathrm{HA}}+R_{\mathrm{LB}}\right)^{2}} .
\end{aligned}
$$

Végezetül vizsgáljuk meg, hogy e két mennyiség korrelációjának a 3. kritérium szerinti, alábbi egyenlősége LH és HL esetben milyen feltételt jelent az ellenállásértékekkel és zajparaméterekkel kifejezve:

$$
\left\langle I_{\mathrm{E}, \mathrm{LH}}(t) V_{\mathrm{E}, \mathrm{LH}}(t)\right\rangle=\left\langle I_{\mathrm{E}, \mathrm{HL}}(t) V_{\mathrm{E}, \mathrm{HL}}(t)\right\rangle .
$$


A (3.26)-(3.29) egyenletek behelyettesítésével a következő egyenlőséget kapjuk:

$$
\begin{aligned}
& \left\langle\frac{V_{\mathrm{HB}}(t)-V_{\mathrm{LA}}(t)}{R_{\mathrm{LA}}+R_{\mathrm{HB}}} \cdot \frac{R_{\mathrm{HB}} V_{\mathrm{LA}}(t)+R_{\mathrm{LA}} V_{\mathrm{HB}}(t)}{R_{\mathrm{LA}}+R_{\mathrm{HB}}}\right\rangle= \\
& =\left\langle\frac{V_{\mathrm{LB}}(t)-V_{\mathrm{HA}}(t)}{R_{\mathrm{HA}}+R_{\mathrm{LB}}} \cdot \frac{R_{\mathrm{LB}} V_{\mathrm{HA}}(t)+R_{\mathrm{HA}} V_{\mathrm{LB}}(t)}{R_{\mathrm{HA}}+R_{\mathrm{LB}}}\right\rangle .
\end{aligned}
$$

A formula bal oldalát tovább írva, és kihasználva, hogy a feszültségzajok független volta miatt a korrelációjuk nulla, a következő alakhoz jutunk:

$$
\begin{aligned}
& \left\langle\frac{R_{\mathrm{LA}} V_{\mathrm{HB}}^{2}(t)+R_{\mathrm{HB}} V_{\mathrm{HB}}(t) V_{\mathrm{LA}}(t)-R_{\mathrm{LA}} V_{\mathrm{HB}}(t) V_{\mathrm{LA}}(t)-R_{\mathrm{HB}} V_{\mathrm{LA}}^{2}(t)}{\left(R_{\mathrm{LA}}+R_{\mathrm{HB}}\right)^{2}}\right\rangle= \\
& =\frac{R_{\mathrm{LA}}}{\left(R_{\mathrm{LA}}+R_{\mathrm{HB}}\right)^{2}}\left\langle V_{\mathrm{HB}}^{2}(t)\right\rangle+\frac{R_{\mathrm{HB}}-R_{\mathrm{LA}}}{\left(R_{\mathrm{LA}}+R_{\mathrm{HB}}\right)^{2}}\left\langle V_{\mathrm{HA}}(t) V_{\mathrm{LB}}(t)\right\rangle-\frac{R_{\mathrm{HB}}}{\left(R_{\mathrm{LA}}+R_{\mathrm{HB}}\right)^{2}}\left\langle V_{\mathrm{LA}}^{2}(t)\right\rangle= \\
& =\frac{R_{\mathrm{LA}}}{\left(R_{\mathrm{LA}}+R_{\mathrm{HB}}\right)^{2}}\left\langle V_{\mathrm{HB}}^{2}(t)\right\rangle-\frac{R_{\mathrm{HB}}}{\left(R_{\mathrm{LA}}+R_{\mathrm{HB}}\right)^{2}}\left\langle V_{\mathrm{LA}}^{2}(t)\right\rangle .
\end{aligned}
$$

Hasonló módon kifejezhetjük a (3.35) egyenlet jobb oldalát is:

$$
\begin{aligned}
& \left\langle\frac{R_{\mathrm{HA}} V_{\mathrm{LB}}^{2}(t)+R_{\mathrm{LB}} V_{\mathrm{HA}}(t) V_{\mathrm{LB}}(t)-R_{\mathrm{HA}} V_{\mathrm{HA}}(t) V_{\mathrm{LB}}(t)-R_{\mathrm{LB}} V_{\mathrm{HA}}^{2}(t)}{\left(R_{\mathrm{HA}}+R_{\mathrm{LB}}\right)^{2}}\right\rangle= \\
& =\frac{R_{\mathrm{HA}}}{\left(R_{\mathrm{HA}}+R_{\mathrm{LB}}\right)^{2}}\left\langle V_{\mathrm{LB}}^{2}(t)\right\rangle+\frac{R_{\mathrm{LB}}-R_{\mathrm{HA}}}{\left(R_{\mathrm{HA}}+R_{\mathrm{LB}}\right)^{2}}\left\langle V_{\mathrm{HA}}(t) V_{\mathrm{LB}}(t)\right\rangle-\frac{R_{\mathrm{LB}}}{\left(R_{\mathrm{HA}}+R_{\mathrm{LB}}\right)^{2}}\left\langle V_{\mathrm{HA}}^{2}(t)\right\rangle= \\
& =\frac{R_{\mathrm{HA}}}{\left(R_{\mathrm{HA}}+R_{\mathrm{LB}}\right)^{2}}\left\langle V_{\mathrm{LB}}^{2}(t)\right\rangle-\frac{R_{\mathrm{LB}}}{\left(R_{\mathrm{HA}}+R_{\mathrm{LB}}\right)^{2}}\left\langle V_{\mathrm{HA}}^{2}(t)\right\rangle .
\end{aligned}
$$

A (3.35)-(3.37) egyenletek alapján tehát a következő feltételhez jutunk:

$$
\begin{aligned}
& \frac{R_{\mathrm{LA}}}{\left(R_{\mathrm{LA}}+R_{\mathrm{HB}}\right)^{2}}\left\langle V_{\mathrm{HB}}^{2}(t)\right\rangle-\frac{R_{\mathrm{HB}}}{\left(R_{\mathrm{LA}}+R_{\mathrm{HB}}\right)^{2}}\left\langle V_{\mathrm{LA}}^{2}(t)\right\rangle= \\
& =\frac{R_{\mathrm{HA}}}{\left(R_{\mathrm{HA}}+R_{\mathrm{LB}}\right)^{2}}\left\langle V_{\mathrm{LB}}^{2}(t)\right\rangle-\frac{R_{\mathrm{LB}}}{\left(R_{\mathrm{HA}}+R_{\mathrm{LB}}\right)^{2}}\left\langle V_{\mathrm{HA}}^{2}(t)\right\rangle .
\end{aligned}
$$

Összeségében tehát a (3.31), (3.33) és (3.38) egyenletek megadják az abszolút biztonságosság három kritériumát az ellenállásértékekkel és a feszültségzajok varianciájával kifejezve. Ezen egyenletrendszer alapján a négy ellenállás és az egyik feszültségzaj varianciájának tetszőleges értékéhez megadható a másik három feszültségzaj varianciája úgy, hogy a (3.31), (3.33) és (3.38) feltételek teljesüljenek. A következőkben tekintsük $V_{\mathrm{LA}}$ effektív értékét adottnak. Ekkor a másik három feszültségzaj varianciájára a (3.31)-(3.38) egyenletrendszer megoldásával a (3.39)(3.41) összefüggések adódnak. 


$$
\begin{aligned}
& \left\langle V_{\mathrm{HB}}^{2}(t)\right\rangle=\left\langle V_{\mathrm{LA}}^{2}(t)\right\rangle \frac{R_{\mathrm{LB}}\left(R_{\mathrm{HA}}+R_{\mathrm{HB}}\right)-R_{\mathrm{HA}} R_{\mathrm{HB}}-R_{\mathrm{HB}}^{2}}{R_{\mathrm{LA}}^{2}+R_{\mathrm{LB}}\left(R_{\mathrm{LA}}-R_{\mathrm{HA}}\right)-R_{\mathrm{HA}} R_{\mathrm{LA}}}, \\
& \left\langle V_{\mathrm{HA}}^{2}(t)\right\rangle=\left\langle V_{\mathrm{LA}}^{2}(t)\right\rangle \frac{R_{\mathrm{HA}}^{2}+R_{\mathrm{LB}}\left(R_{\mathrm{HB}}+R_{\mathrm{HA}}\right)+R_{\mathrm{HA}} R_{\mathrm{HB}}}{R_{\mathrm{LA}}^{2}+R_{\mathrm{LB}}\left(R_{\mathrm{LA}}+R_{\mathrm{HB}}\right)+R_{\mathrm{HB}} R_{\mathrm{LA}}}, \\
& \left\langle V_{\mathrm{LB}}^{2}(t)\right\rangle=\left\langle V_{\mathrm{LA}}^{2}(t)\right\rangle \frac{R_{\mathrm{LB}}^{2}+R_{\mathrm{LB}}\left(R_{\mathrm{HA}}-R_{\mathrm{HB}}\right)-R_{\mathrm{HA}} R_{\mathrm{HB}}}{R_{\mathrm{LA}}^{2}+R_{\mathrm{LA}}\left(R_{\mathrm{HB}}-R_{\mathrm{HA}}\right)-R_{\mathrm{HA}} R_{\mathrm{HB}}} .
\end{aligned}
$$

A (3.39)-(3.41) egyenletek tehát megadják az abszolút biztonságosság zajgenerátorok skálázására vonatkozó feltételeket. Természetesen e feltételek bármelyik másik feszültségzaj varianciájának függvényében is megadhatóak. Az egyik zajgenerátor effektív értékének tetszőleges megválasztása lehetővé teszi a kommunikációhoz szükséges megfelelő jelerősség beállítását Alice és Bob számára.

A 3.3. fejezetben megadott, abszolút biztonságosságra vonatkozó 3. kritérium, azaz a korrelációk egyenlőségének megadásánál kihasználtuk, hogy normális eloszlású zajok esetén a korreláció egyértelműen meghatározza a két mennyiség függőségét. Ebből következően a magasabb rendű momentumok egyenlőségét nem kell feltételként megszabnunk. Ez jól látszik Isserlis tétele alapján is, mivel a magasabb momentumok kifejezhetőek a varianciák és kovarianciák segítségével, melyek egyenlősége LH és HL esetben a három kritériumnak megfelelően teljesül [34]. Másrészől, mivel az Eve által mérhető két mennyiség függőségét csak normális eloszlás esetén adja meg egyértelműen a korreláció, így (a (3.31), (3.33) és (3.38) egyenletekben foglalt megkötések esetén) az abszolút biztonságosság feszültségzajok eloszlására vonatkozó feltétele azok normális eloszlása.

Mint láthattuk, az imént bevezetett, általánosított rendszer esetében $V_{\mathrm{E}}$ és $I_{\mathrm{E}}$ nem független, azaz korrelációjuk nem nulla értékű, statisztikai eszközökkel mégsem tud Eve különbséget tenni LH és HL állapotok között. A (3.39)-(3.41) egyenletekből látható, hogy az eredetei KLJN rendszer esetében, azaz amikor $R_{\mathrm{L}}=R_{\mathrm{LA}}=R_{\mathrm{LB}}$ és $R_{\mathrm{H}}=R_{\mathrm{HA}}=R_{\mathrm{HB}}$, azok a (3.24) skálázási feltételre egyszerűsödnek. Ez esetben a (3.38) egyenlet mindkét oldala, azaz $V_{\mathrm{E}}$ és $I_{\mathrm{E}} \mathrm{LH}$ és HL állapotban vett korrelációjának értéke nulla, tehát (mivel normális eloszlásúak) függetlenek, mely megfelel a 3.2.2. fejezetben bemutatottaknak, és jól mutatja, hogy az eredeti KLJN rendszer az általánosított rendszer egy speciális - az elrendezés szempontjából szimmetrikus esete.

A fizikai megközelítés szerint e speciális esetben nincs energiaáramlás a két oldal között, azaz a rendszer termikus egyensúlyban van. Az általánosítás során a 3. kritérium megfogalmazásával, azaz $V_{\mathrm{E}}$ és $I_{\mathrm{E}}$ egymástól való függésének megengedésével azonban, ahogy a korreláció $\left\langle I_{\mathrm{E}} V_{\mathrm{E}}>\right.$ alakjából is látható, a vezetéken mérhető teljesítmény különbözhet nullától. Azonban ennek az energiaáramlásnak (3.34) illetve a (3.38) egyenletek szerint meg kell egyeznie LH és HL esetben, mely 
megfelel a termodinamika második főtételének teljesülését kihasználó támadások elleni védekezés kapcsán levezetett fizikai megfontolásoknak [56].

Ebből következően az általánosított rendszer a fizikai interpretáció szerint nincs termikus egyensúlyban. Ez jól látható a (3.39)-(3.41) egyenletekből is, hiszen a feszültségzajok varianciája egyenesen arányos az ellenállások hőmérsékletével, azaz a rendszer fizikai értelemben interpretálható - a KLJN bevezetésénél látott, zajgenerátorokat nélkülöző - különböző hőmérsékletű ellenállások kapcsolásaként.

\subsubsection{Numerikus szimulációk}

Az elméleti eredmények alapján látható, hogy az általánosított rendszer esetében, bár $V_{\mathrm{E}}$ és $I_{\mathrm{E}}$ nem független, azonban azok varianciája és korrelációja statisztikai eszközökkel megkülönböztethetetlen Eve számára LH és HL állapotban. Ennek alátámasztására és demonstrálására numerikus szimulációkat is készítettem LabVIEW környezetben, melyek letölthetőek, továbbá az eredményeket videókkal is illusztráltam [79].

A rendszer szimulációját a 3.2.1. fejezethez hasonlóan készítettem el; a független, normális eloszlású feszültségzajokat véletlenszám-generátorok állítják elő, melyekből az Eve által mérhető feszültég $\left(V_{\mathrm{E}}(t)\right)$ és áramerősség $\left(I_{\mathrm{E}}(t)\right)$ a (3.26)-(3.29) összefüggések szerint került kiszámításra. A négy ellenállásérték illetve $V_{\text {LA }}$ zajgenerátor effektív értékének beállítása után a másik három zajgenerátor effektív értékét a (3.39)-(3.41) egyenletek szerint határoztam meg. Egy bit átvitelének LH illetve HL állapotbeli szimulációja 1000 pontból álló feszültségzajokkal történt.

A 3.9. ábrán egy aszimmetrikus elrendezés mellett látható egy bit esetén $V_{\mathrm{E}}$ és $I_{\mathrm{E}}$ szórásdiagramja, LH és HL állapotban (az ábrafeliratban az ellenállások értékei mellett a zajgenerátorok effektív értékei kerülnek megadásra). Mint látható, a két mennyiség nem független, azonban a két állapot nem megkülönböztethető.
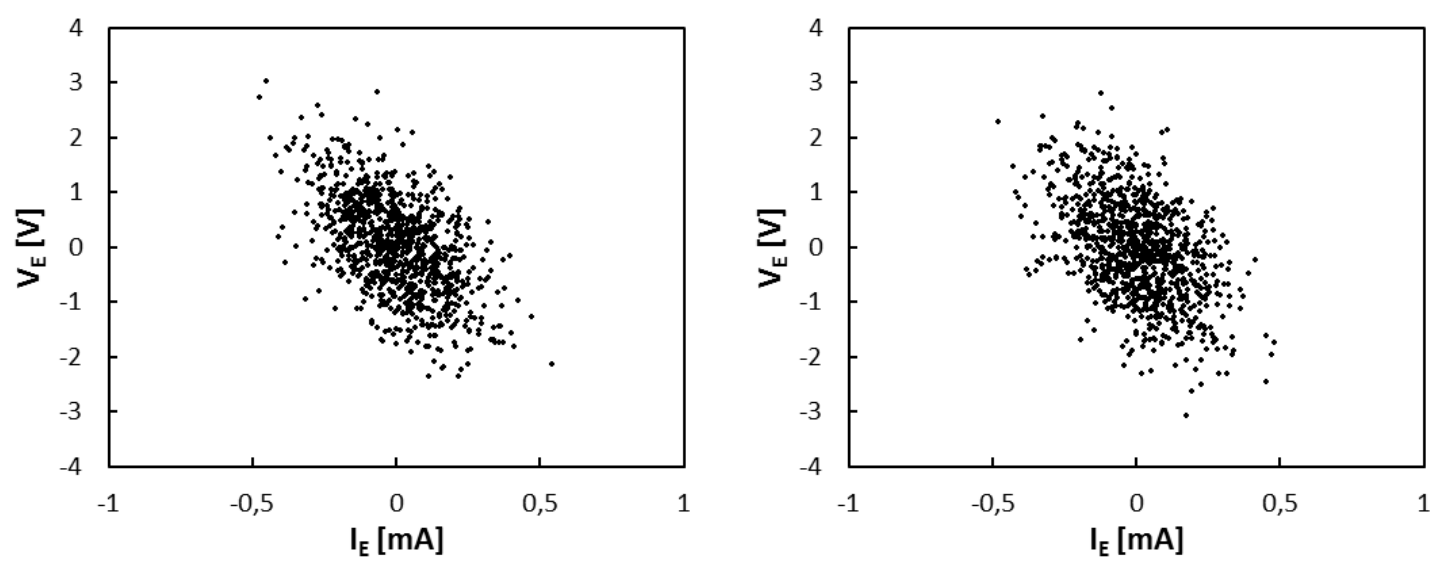

3.9. ábra: $V_{\mathrm{E}}$ és $I_{\mathrm{E}}$ szórásdiagramja egy bit átvitele esetén a két állapotban. A rendszer elemeinek értékei LH állapotban (bal oldalon): $R_{\mathrm{LA}}=1 \mathrm{k} \Omega, R_{\mathrm{HB}}=9 \mathrm{k} \Omega, V_{\mathrm{LA}}=1 \mathrm{~V}$, $V_{\mathrm{HB}}=1,186 \mathrm{~V}$, HL állapotban (jobb oldalon): $R_{\mathrm{HA}}=10 \mathrm{k} \Omega, R_{\mathrm{LB}}=5 \mathrm{k} \Omega, V_{\mathrm{HA}}=2,179 \mathrm{~V}$, $V_{\mathrm{LB}}=0,816 \mathrm{~V}$. 

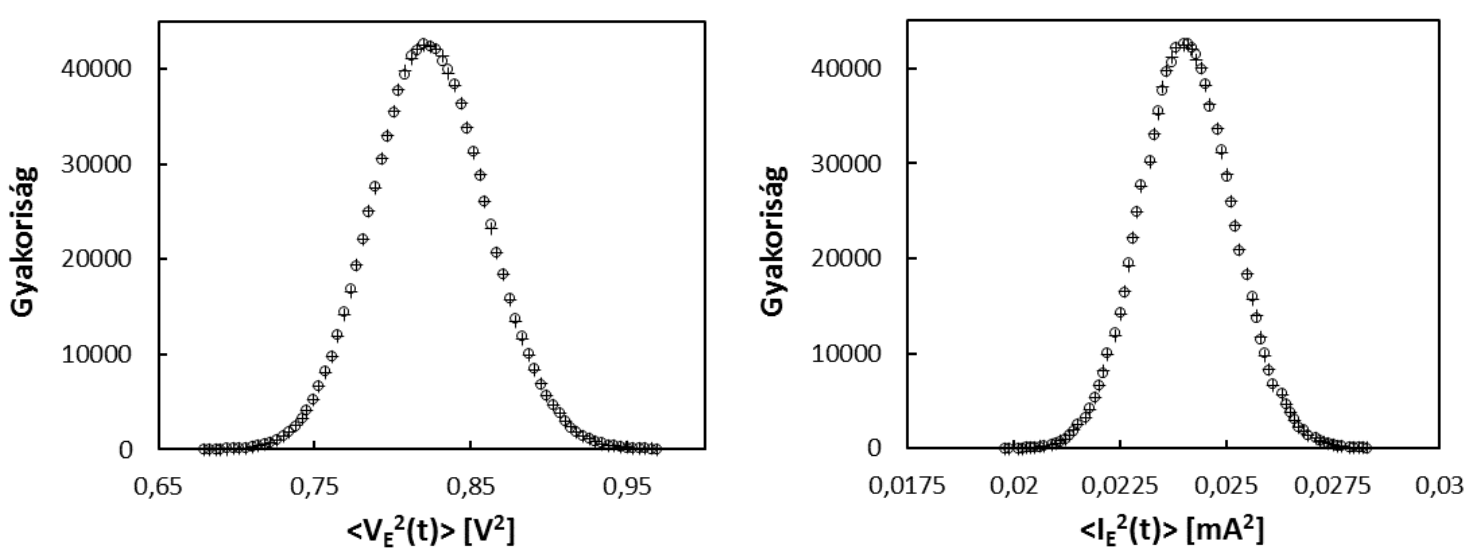

3.10. ábra: Az Eve által mérhető feszültség (bal oldalon) és áramerősség (jobb oldalon) bitenként számított varianciájának hisztogramja $10^{6}$ bit átvitele esetén, aszimmetrikus elrendezést felhasználva. A rendszer elemeinek értékei LH állapotban (körrel jelölve): $R_{\mathrm{LA}}=1 \mathrm{k} \Omega, R_{\mathrm{HB}}=9 \mathrm{k} \Omega, V_{\mathrm{LA}}=1 \mathrm{~V}, V_{\mathrm{HB}}=1,186 \mathrm{~V}$, HL állapotban (kereszttel jelölve): $R_{\mathrm{HA}}=10 \mathrm{k} \Omega, R_{\mathrm{LB}}=5 \mathrm{k} \Omega, V_{\mathrm{HA}}=2.179 \mathrm{~V}, V_{\mathrm{LB}}=0,816 \mathrm{~V}$.

Az egy bit átvitele során Eve által mérhető varianciák és korrelációk LH és HL állapotban való statisztikai megkülönböztethetetlenségét $10^{6}$ bit szimulálásával vizsgáltam meg. A 3.10. ábrán, az egyes bitátvitelek esetén mérhető varianciáknak az összes bit átvitelére számított hisztogramja alapján jól látható, hogy az eloszlások LH és HL esetben teljesen egybe esnek, tehát Eve statisztikailag nem tud különbséget tenni a két állapot között.

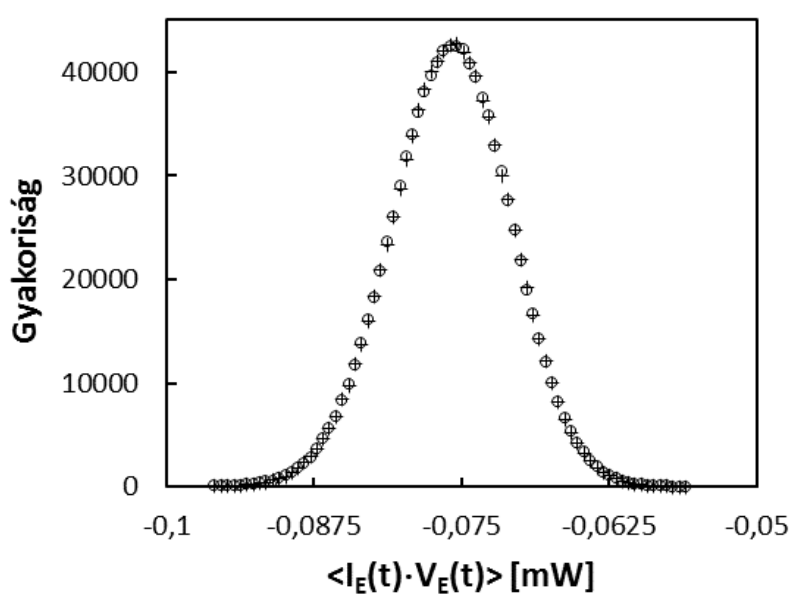

3.11. ábra: Az Eve által mérhető feszültség és áramerősség bitenként számított korrelációjának hisztogramja $10^{6}$ bit átvitele esetén, aszimmetrikus elrendezést felhasználva. A rendszer elemeinek értékei LH állapotban (körrel jelölve): $R_{\mathrm{LA}}=1 \mathrm{k} \Omega$, $R_{\mathrm{HB}}=9 \mathrm{k} \Omega, V_{\mathrm{LA}}=1 \mathrm{~V}, V_{\mathrm{HB}}=1,186 \mathrm{~V}, \mathrm{HL}$ állapotban (kereszttel jelölve): $R_{\mathrm{HA}}=10 \mathrm{k} \Omega$, $R_{\mathrm{LB}}=5 \mathrm{k} \Omega, V_{\mathrm{HA}}=2.179 \mathrm{~V}, V_{\mathrm{LB}}=0,816 \mathrm{~V}$.

A 3.11. ábrán hasonló módon, az egyes bitátvitelekre számított korrelációknak az összes bit esetén vett hisztogramja látható. Ahogyan az aszimmetrikus szóródási képből is következik, illetve az előbbiekben vázolt elméleti megfontolásoknak 
megfelelően a korreláció értéke nem nulla, azonban LH és HL állapotban azonos, azaz statisztikailag a két állapot nem megkülönböztethető.

A 3.12. ábrán az eredeti KLJN rendszernek megfelelő, szimmetrikus elrendezés szimulációjának eredményei alapján jól látható, hogy a konfiguráció az általánosított rendszer azon speciális esete, amikor a korreláció átlagos értéke nulla, azaz a vezetéken mérhető feszültség és áramerősség független.
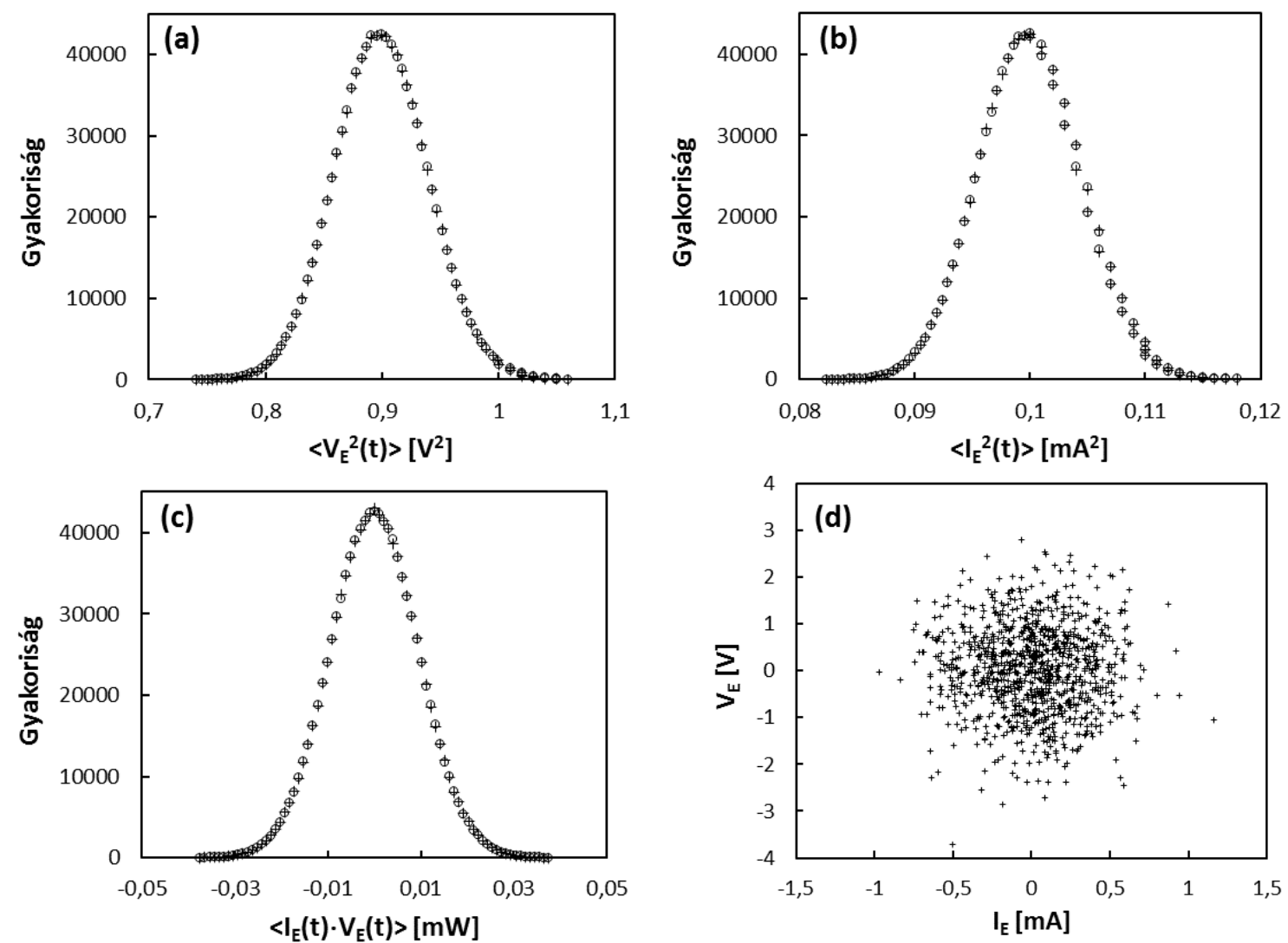

3.12. ábra: Az Eve által mérhető feszültség (a), áramerősség (b) és azok korrelációja (c) bitenként számított varianciájának hisztogramja $10^{6}$ bit átvitele esetén, illetve $V_{\mathrm{E}}$ és IE szórásdiagramja egy bitátvitel esetén (d), szimmetrikus elrendezést felhasználva. A rendszer elemeinek értékei LH esetben (körrel jelölve): $R_{\mathrm{LA}}=1 \mathrm{k} \Omega$, $R_{\mathrm{HB}}=9 \mathrm{k} \Omega, V_{\mathrm{LA}}=1 \mathrm{~V}, V_{H B}=3 \mathrm{~V}$, HL esetben pedig (kereszttel jelölve): $R_{\mathrm{HA}}=9 \mathrm{k} \Omega, R_{\mathrm{LB}}=1 \mathrm{k} \Omega$, $V_{\mathrm{HA}}=3 \mathrm{~V}, V_{\mathrm{LB}}=1 \mathrm{~V}$.

A 3.13. ábrán egy érdekes elrendezés szimulációjának eredményei láthatóak. Ebben a konfigurációban Alice $\mathrm{H}$ állapotához tartozó nagyobb ellenállásérték megegyezik Bob L állapotához tartozó kis ellenállásértékkel, azaz $R_{\mathrm{HA}}=R_{\mathrm{LB}}$. Mint látható, a kulcscsere biztonságos módon megvalósítható így is, sőt olyan esetben is, amikor $R_{\mathrm{HA}}<R_{\mathrm{LB}}$. Az egyetlen megkötés a korábbiaknak megfelelően az, hogy egy oldalon nem lehet egyenlő a két ellenállás. Az elrendezés ettől függetlenül abból a szempontból is speciális, hogy a két állapotban a hurokellenállás egyenlo, azaz $R_{\mathrm{HA}}+R_{\mathrm{LB}}=R_{\mathrm{LA}}+R_{\mathrm{HB}}$. Ekkor a két oldal zajgenerátor-párjainak a (3.39)-(3.41) egyenletek szerint adódó effektív értéke megegyezik, azaz $V_{\mathrm{LA}}=V_{\mathrm{LB}}$ és $V_{\mathrm{HA}}=V_{\mathrm{HB}}$. 

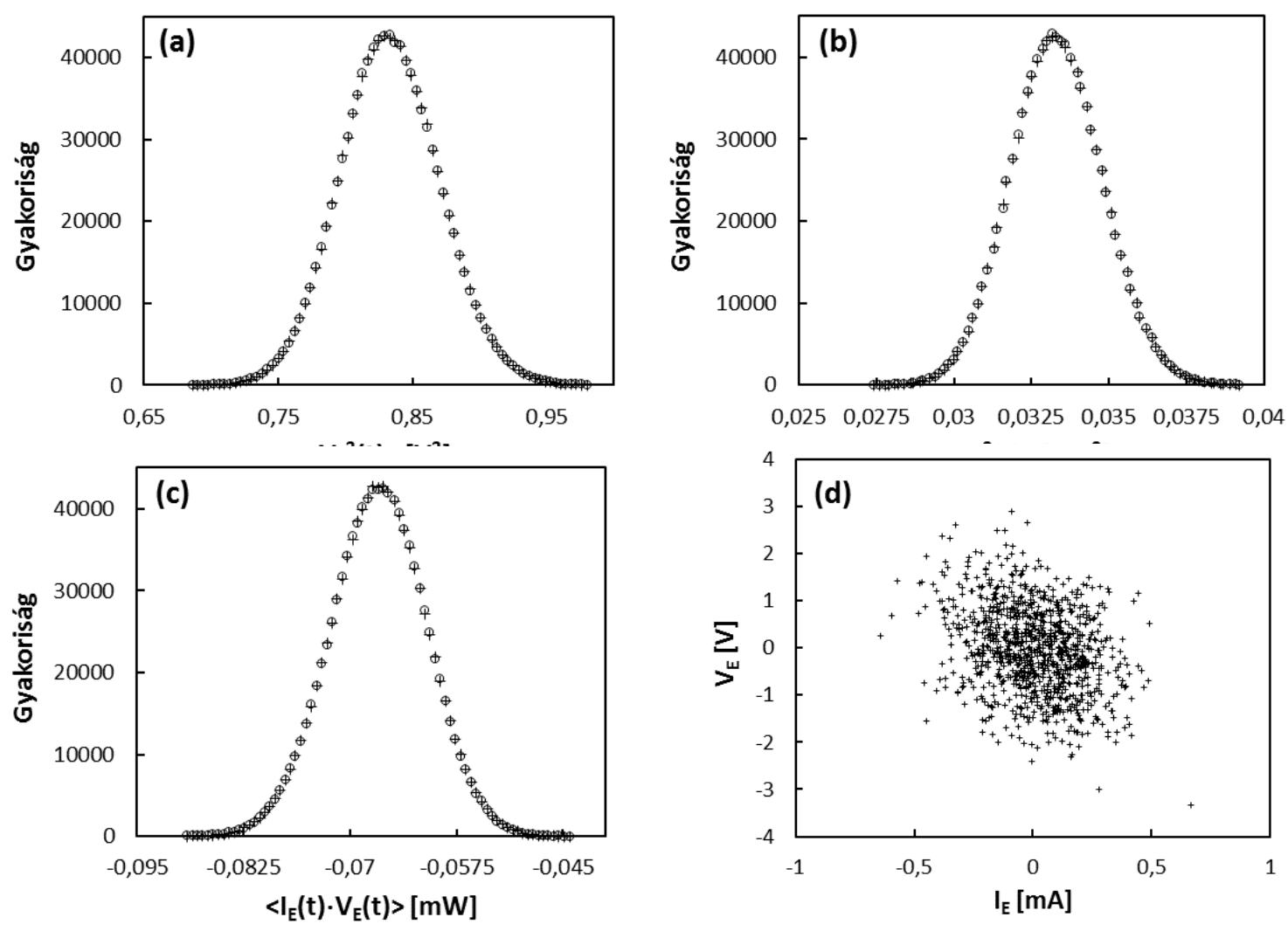

3.13. ábra: Az Eve által mérhető feszültség (a), áramerősség (b) és azok korrelációja (c) bitenként számított varianciájának hisztogramja $10^{6}$ bit átvitele esetén, illetve $V_{\mathrm{E}}$ és $I_{E}$ szórásdiagramja egy bitátvitel esetén (d), aszimmetrikus elrendezést felhasználva. A rendszer elemeinek értékei LH esetben (körrel jelölve): $R_{\mathrm{LA}}=1 \mathrm{k} \Omega$, $R_{\mathrm{HB}}=9 \mathrm{k} \Omega, V_{\mathrm{LA}}=1 \mathrm{~V}, V_{\mathrm{HB}}=1,527 \mathrm{~V}$, HL esetben pedig (kereszttel jelölve): $R_{\mathrm{HA}}=5 \mathrm{k} \Omega$, $R_{\mathrm{LB}}=5 \mathrm{k} \Omega, V_{\mathrm{HA}}=1,527 \mathrm{~V}, V_{\mathrm{LB}}=1 \mathrm{~V}$.

A két állapot megkülönbözthetősége a titkosítás szempontjából azzal mérhető, hogy Eve milyen arányban találja el a kulcs bitjeinek értékét. Ennek a kriptográfiában, illetve a QKD és a KLJN vizsgálatának irodalmában is bevett mérőszáma a bithibaarány (bit error rate - BER), mely a hibásan meghatározott bitek és a kulcs összes bitjének aránya százalékosan kifejezve. Ebből következően annak a valószínűsége, hogy Eve helyesen talál egy kulcsbitet: 1-BER/100. Ha nem áll rendelkezésére semmilyen információ, Eve véletlenszerűen tippelhet a bitek két értéke között, ekkor könnyen belátható, hogy a BER értéke 50\%-hoz tart.

Jelen esetben $V_{\mathrm{E}}$ és $I_{\mathrm{E}}$ varianciáinak és korrelációjának nagyszámú statisztikájából próbálhat Eve információt szerezni. Ezt úgy teheti meg, hogy összes érték alapján meghatároz egy küszöbszintet, mely alatti értékekhez az egyik, az a feletti értékekhez pedig a másik feltételezett állapotot, azaz bit értéket rendeli. Ha az LH és HL állapot hisztogramja a 3.10.-3.14. ábrákon látottakkal ellentétben nem fed teljesen át, a $B E R$ értéke $50 \%$ alatti lesz, azaz információszivárgás lép fel. Mivel a kulcsgenerálás során a kulcs bitjeiben az LH és HL állapotok aránya 0,5-höz tart, ha 
Eve a mért értékek mediánját alkalmazza küszöbszintként, biztos, hogy ugyanolyan arányban találja el helyesen a két állapotot. Minden más küszöbszint esetén igaz, hogy bár az az egyik bit eltalálásának valószínűségét növelheti, a másiké ugyanakkor csökkenni fog. A mediánnal megállapított BER értéke egyezik tehát, akár az LH akár a HL állapotok helyes találatát vizsgáljuk.

Fontos megjegyezni, hogy a két elkülönített csoporthoz Eve kétféleképpen is rendelheti a kép állapotot, így az egyik esetben a $B E R$ érték annyival nagyobb lesz 50\%-nál, mint amennyivel az ellentétes esetben kisebb. Mivel a két kulcs egymás inverze, így igaz az állítás, miszerint Eve mindenképp rendelkezik valamely többletinformációval, így $\mathrm{mi}$ az Alice és Bob szemszögéből rosszabb esetet feltételezve tegyük fel, hogy Eve helyesen társítja az LH és HL állapotot a két (feltételezetten) elkülönülő csoporthoz. Ekkor a BER maximális értéke, amely a nulla értékű információszivárgásnak, azaz az abszolút biztonságos kommunikációnak felel meg, 50\%.

\begin{tabular}{|c|c|c|c|c|c|c|}
\hline \multicolumn{2}{|c|}{$\mathrm{HL}$} & \multicolumn{2}{c|}{$\mathrm{LH}$} & $\left\langle I_{\mathrm{E}}^{2}(t)\right\rangle$ & $\left\langle V_{\mathrm{E}}^{2}(t)\right\rangle$ & $\left\langle V_{\mathrm{E}}(t) I_{\mathrm{E}}(t)\right\rangle$ \\
\hline$R_{\mathrm{HA}}[\mathrm{k} \Omega]$ & $R_{\mathrm{LB}}[\mathrm{k} \Omega]$ & $R_{\mathrm{LA}}[\mathrm{k} \Omega]$ & $R_{\mathrm{HB}}[\mathrm{k} \Omega]$ & $B E R[\%]$ & $B E R[\%]$ & $B E R[\%]$ \\
\hline 9 & 1 & 1 & 9 & 49,967 & 49,973 & 49,994 \\
\hline 10 & 5 & 1 & 9 & 49,985 & 49,980 & 49,979 \\
\hline 5 & 5 & 1 & 9 & 49.981 & 49,984 & 49,981 \\
\hline
\end{tabular}

3.1. táblázat: A $V_{\mathrm{E}}$ és $I_{\mathrm{E}}$ varianciája és korrelációja alapján meghatározott $B E R$ értékek az általánosított rendszer három különböző konfigurációja esetén, $10^{6}$ bit átvitelének numerikus szimulációjával.

Ennek megfelelően, a $10^{6}$ számú bitátvitel szimulálásával kapott varianciák és a korreláció értékeinek mediánját küszöbszintként véve minden bit esetén (mind a varianciák és a korreláció esetében külön-külön) meghatároztam egy feltételezett állapotot, és kiszámítottam a $B E R$ értékét, melynek eredménye az eddigiekben vizsgált három konfiguráció esetén a 3.1. táblázatban látható. A $B E R$ értéke minden esetben nagyon közel esik az 50\%-os értékhez, az attól való kis eltérést a véges számú bitre végzett szimuláció okozza, azaz gyakorlati értelemben nincs információszivárgás.

\subsubsection{Az eredmények rövid összegzése és a rendszer előnyei}

Az elméleti eredményeink és az azokat alátámasztó numerikus vizsgálatok alapján a KLJN kulcsmegosztó protokoll abszolút biztonságos jóval általánosabb feltételek esetén is. A két kommunikáló fél által használt ellenálláspároknak nem kell azonos értékűnek lennie, a fentiekben megadott összefüggésekkel megválasztható a zajgenerátorok effektív értéke úgy, hogy a lehallgató semmilyen módon ne tudjon 
különbséget tenni az LH és HL állapotok között. A tetszőleges ellenállásértékek és a feszültségzajok varianciái közötti általánosított összefüggések meghatározásához azt használtuk ki, hogy a rendszer abszolút biztonságosságához kevesebb megkötést tartalmazó kritériumok is elegendőek. Az Eve által mérhető $V_{\mathrm{E}}$ és IE mennyiségeknek nem kell függetlennek lennie, elegendő, ha varianciáik és korrelációjuk statisztikai eszközökkel megkülönböztethetetlen LH és HL állapotban, melyből levezettük a zajparaméterekre vonatkozó feltételeket.

Az általánosított rendszer gyakorlati alkalmazásának az alábbiakban bemutatott előnyein túl eredményeink új megvilágításba helyezik a KLJN abszolút biztonságosságához szükséges követelmények klasszikus fizikai interpretációját is. E szerint ugyanis az általánosított rendszer nincs termikus egyensúlyban, továbbá a vezetéken mérhető két mennyiség - LH és HL esetben egyenlő - korrelációja energiaáramlást jelent a két kommunikáló fél között. Az eredeti KLJN rendszer, melyben ez az energiaáramlás nulla, az általánosított rendszer egy speciális szimmetrikus - esete.

Ezen eredmények hatására Kish a KLJN protokoll biztonságosságának klasszikus fizikai leírását a termodinamika második fótétele helyett a fluktuációdisszipáció tételét felhasználva újraértelmezte [80]. Ezen túlmenően, az energiaáramlás ellenére is biztosítható abszolút biztonságosság lehetőségét bizonyító eredményeink egy új protokoll bevezetését is inspirálták [80]. Ezen új, RandomResistor-Random-Temperature (RRRT) KLJN rendszerben Alice és Bob nem rögzített értékú ellenállás- és zajgenerátor párokkal dolgozik, hanem minden bitátvitel esetében véletlenszerú értékü komponenst használ. A rendszer így jelentősen eltér az eddigiektől, például nem beszélhetünk rögzített LH és HL esetekről, hanem egy aktuális állapotban vizsgáljuk, melyik oldalon van a nagyobb értékủ ellenállás. Míg az eddigi protokollok esetében a komponensek értékei publikusak voltak, ez esetben sem Eve, sem a másik fél nem tudja, éppen milyen értékekkel dolgozik a partnere. A rendszer abszolút biztonságossága azon alapszik, hogy Eve ez esetben is három mennyiséget tud mérni, míg négy érték ismeretlen számára, így nem tudja kitalálni, melyik oldalon van a nagyobb értékű ellenállás. Ezzel szemben a kommunikáló felek ismerik, milyen értéket választottak a saját részükről, így az Eve által is mérhető mennyiségekkel együtt meg tudják határozni a másik fél ellenállásának értékét. Az RRRT KLJN protokoll bevezetése hasznosnak bizonyult a legújabb, a rendszer állapotváltásakor fellépő tranziens szakaszait kihasználó támadás ellen, melynek lényege, hogy rögzített értékű komponensek használatakor, egy bit átvitelének kezdetekor a jel véges időn belül jut ez a vezeték túloldalára, mely időből következtetni lehet az aktuális elrendezésre [63, 81].

A protokoll általánosítása gyakorlati szempontból is igen fontos előrelépés, hiszen rugalmassága elősegíti a valós rendszerek biztonságosságának javítását és új implementációk megvalósítását. Egyrészt a két kommunikáló félnek nem kell arra 
törekednie, hogy azonos ellenálláspárral rendelkezzen, másrészről minden alkatrész rendelkezik valamekkora toleranciával, azaz a teljesen szimmetrikus elrendezés is csak valamekkora mértékű hibával valósítható meg. A két állapot között váltó kapcsolók és egyéb alkatrészek parazitaellenállása illetve az alkatrészek értékének hőmérsékletfüggése a két oldal között eltérést, azaz az eredeti rendszer esetében információszivárgást okozott, míg az új rendszerben ez a tetszőlegesen választható ellenálláspároknak köszönhetően könnyedén eliminálható a zajgenerátorok effektív értékének finomhangolásával. A rendszer gyakorlati megvalósításának szempontjából ez rendkívüli előnyt jelent, hiszen a zajgenerátorok hangolása igen egyszerűen megvalósítható a modern analóg és digitális áramkörök segítségével. Így az egyszerűbb megvalósításon túl jelentősen csökken a rendszer alkatrészek pontatlanságára való érzékenysége, melyre számos, a gyakorlati megvalósításból adódó információszivárgást kihasználó támadás épült. A két kommunikáló fél által használt komponensek pontatlanságából származó hiba (továbbá a kommunikációs vezeték ellenállása okozta hiba) kompenzálásának gyakorlati megvalósítását, továbbá az így eliminálható információszivárgás mértékét részletesebben a következő fejezetben tárgyaljuk, azonban fontos leszögezni, hogy erre a lehetőséget a rendszer általánosítása adta meg.

A 3.3 fejezetben bemutatott eredményeket az értekezés 2. tézispontja foglalja össze.

\section{4 Általánosított KLJN kulcsmegosztó rendszer gyakorlati alkalmazásokhoz}

A KLJN rendszer gyakorlatban való alkalmazása szempontjából kulcsfontosságú kérdés, hogy a megvalósítás során az idealizált modellektől való eltérés milyen hatással van a rendszer biztonságosságára. A KLJN protokoll elleni támadások jelentős része a nem-ideális KLJN rendszerre irányult [47, 52-58]. Ilyen eltérést okozhat a megvalósításhoz szükséges komponensek értékének pontatlansága, hőmérséklettől való függése vagy olyan plusz komponensek fizikai paramétereinek figyelembevétele, melyet az ideális modell elhanyagolt, mint például a kommunikációt biztosító vezeték ellenállása.

Ez utóbbi a KLJN protokoll számos korábbi támadásainak tárgyát képezte [47, $52,53]$, mivel a vezeték az imént említett többi komponenssel ellentétben az Alice és Bob által használt kommunikátorokon kívül helyezkedik el, ebből fakadóan Eve több különböző ponton is hajthat végre rajta méréseket, a nem elhanyagolható értékű $\left(R_{\mathrm{C}}\right)$ ellenállásából fakadóan következtetéseket vonhat le például a különböző pontok közötti feszültégesésből vagy az energiaáramlásból. A disszertációban eddig használt megközelítés szerint úgy vizsgálhatjuk a vezetékellenállás hatását, hogy az Eve megfigyelési pontja és Alice közötti vezetékellenállásrészt az Alice által használt 
ellenállás értékéhez adjuk hozzá, a fennmaradó részt pedig a Bob által használt ellenállás értékéhez. Az egyszerűség kedvéért tekintsük először azt az esetet, mikor Eve pontosan a vezeték közepén mér. Ekkor, míg Alice és Bob a feszültségzajok varianciáinak arányát az általuk használt $R_{\mathrm{HA}}, R_{\mathrm{LB}}, R_{\mathrm{LA}}, R_{\mathrm{HB}}$ értékei szerint állítja be, a valóságban a vezeték közepén mérhető feszültséget és áramerősséget $R_{\mathrm{HA}}+R_{\mathrm{C}} / 2$, $R_{\mathrm{LB}}+R_{\mathrm{C}} / 2 ， R_{\mathrm{LA}}+R_{\mathrm{C}} / 2, \quad R_{\mathrm{HB}}+R_{\mathrm{C}} / 2$ értékek lineáris kombináció adják meg, így információszivárgás lép fel.

Ha Eve nem középen mér, más arányban változik Alice és Bob ellenállásainak értéke, azaz egy aszimmetrikus elrendezéshez jutunk. Amennyiben Alice és Bob ismeri Eve mérésének helyét és megméri $R_{\mathrm{C}}$ értékét, természetesen az eddig bemutatott eredményeink alapján a zajgenerátorok effektív értékét az abszolút biztonságosság kritériumainak megfelelően módosíthatja. Azonban valós esetben nagy valószínűséggel Eve mérési pontjának (vagy pontjainak) helyét nem ismeri a két kommunikáló fél, így felmerül a kérdés, mit tehet Alice és Bob a biztonságosság fenntartásához?

Kish az eredeti rendszerre bevezetett egy eliminációs módszert, amely megadja a zajgenerátorok abszolút biztonságossághoz szükséges skálázását egy adott $R \mathrm{C}$ esetén, azonban független Eve megfigyelési pontjától [56]. Megjegyzendő, hogy Kish az előbbiektől eltérő megközelítést alkalmazott; feltette, hogy Eve a vezeték két végén is végez mérést, és klasszikus fizikai törvényeken alapuló bizonyítása szerint az eliminációs módszer alkalmazásával a kommunikáció abszolút biztonságos marad. Ezen eredmények értelmezése előtt vizsgáljuk meg általánosabb esetben a vezetékellenállással kiegészített modellt, és azt, hogy hasonló kompenzáció megvalósítható-e az általánosított, eleve aszimmetrikus rendszerre.

\subsubsection{A vezeték ellenállásának figyelembevétele}

A 3.8. ábrán szereplő általánosított modellt egészítsük ki a vezeték $R \mathrm{C}$ ellenállásával a 3.14. ábrán látható módon. Az ábrán $q$ jelöli az Eve által használt relatív megfigyelési pontot, értéke 0 a vezeték Alice felőli, illetve 1 a Bob felőli végén, közöttük pedig a vezeték hosszával arányosan változik.

Ekkor a 3.3.1. fejezethez hasonlóan eljárva, az Eve által a vezetéken, a megfigyelési ponton mérhető mennyiségeket az alábbi összefüggések adják meg LH állapotban:

$$
\begin{aligned}
& I_{\mathrm{E}, \mathrm{LH}}(t)=\frac{V_{\mathrm{HB}}(t)-V_{\mathrm{LA}}(t)}{R_{\mathrm{LA}}+R_{\mathrm{HB}}+R_{\mathrm{C}}}, \\
& V_{\mathrm{E}, \mathrm{LH}}(t)=\frac{\left(R_{\mathrm{HB}}+(1-q) \cdot R_{\mathrm{C}}\right) \cdot V_{\mathrm{LA}}(t)+\left(R_{\mathrm{LA}}+q \cdot R_{\mathrm{C}}\right) \cdot V_{\mathrm{HB}}(t)}{R_{\mathrm{LA}}+R_{\mathrm{HB}}+R_{\mathrm{C}}},
\end{aligned}
$$


HL állapotban pedig:

$$
\begin{aligned}
I_{\mathrm{E}, \mathrm{HL}}(t) & =\frac{V_{\mathrm{LB}}(t)-V_{\mathrm{HA}}(t)}{R_{\mathrm{HA}}+R_{\mathrm{LB}}+R_{\mathrm{C}}}, \\
V_{\mathrm{E}, \mathrm{HL}}(t) & =\frac{\left(R_{\mathrm{LB}}+(1-q) \cdot R_{\mathrm{C}}\right) \cdot V_{\mathrm{HA}}(t)+\left(R_{\mathrm{HA}}+q \cdot R_{\mathrm{C}}\right) \cdot V_{\mathrm{LB}}(t)}{R_{\mathrm{HA}}+R_{\mathrm{LB}}+R_{\mathrm{C}}} .
\end{aligned}
$$

Alice

Bob

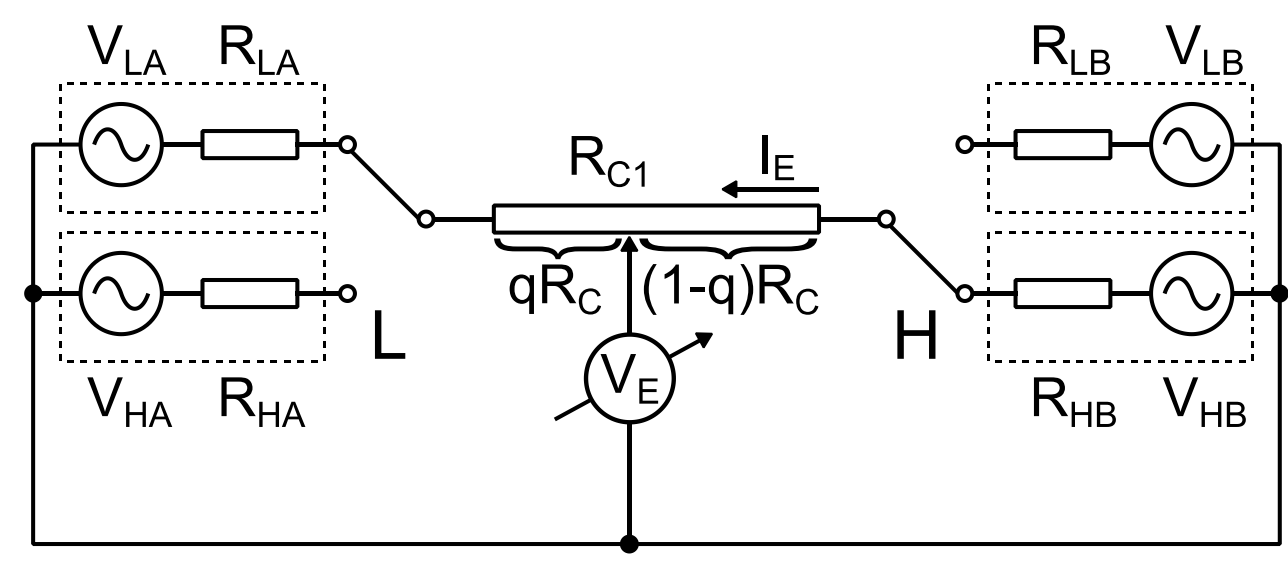

3.14. ábra: $\mathrm{Az}$ általánosított $\mathrm{KLJN}$ rendszer modellje a kommunikációs vezeték $R_{\mathrm{C}}$ ellenállásának, illetve Eve $q$ relatív megfigyelési pontjának figyelembevételével, LH állapotban.

\section{Alice}

Bob

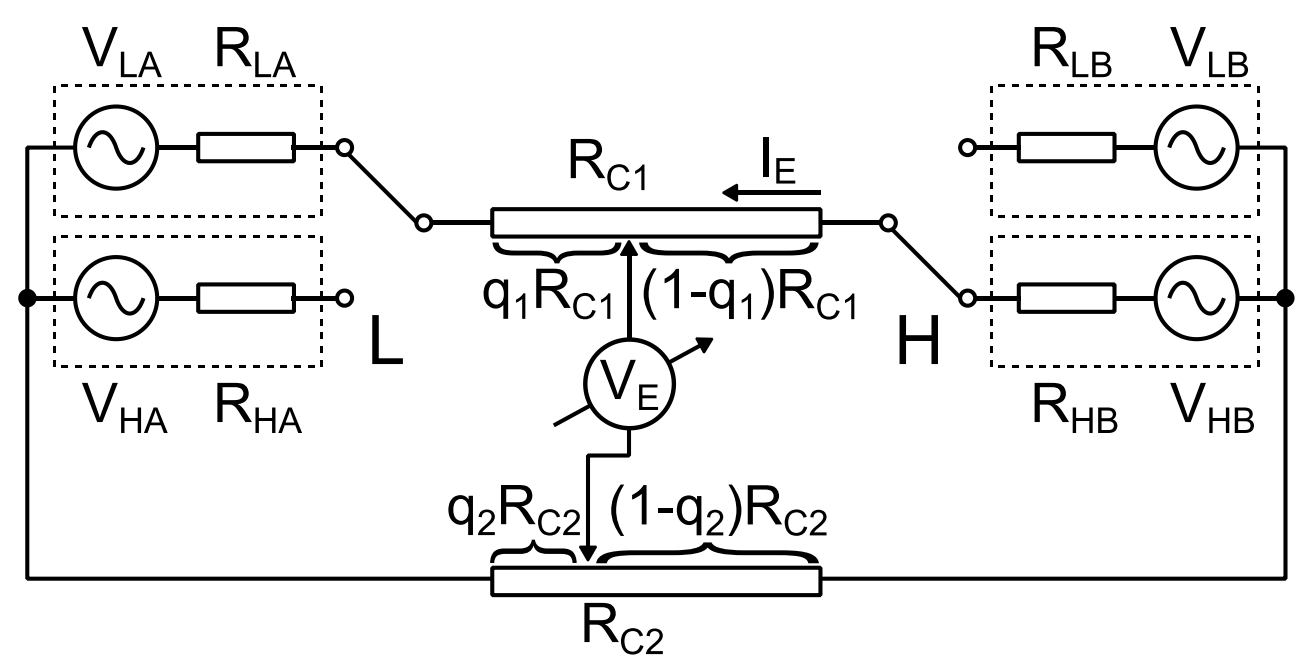

3.15. ábra: Az általánosított KLJN rendszer modellje a kommunikációs vezeték $R_{\mathrm{C} 1}$ ellenállásának és Eve $q_{1}$ megfigyelési pontjának, illetve a referenciavezeték $R_{\mathrm{C} 2}$ ellenállásának és Eve $q_{2}$ megfigyelési pontjának figyelembevételével LH állapotban. 
Ahogyan a kommunikációs vezeték ellenállását figyelembe vettük, a két fél által használt közös referenciavezeték ellenállása sem minden esetben hanyagolható el. Járjunk el ez esetben is a kommunikációs vezetékhez hasonlóan: jelölje $R_{\mathrm{C} 1}$ a kommunikációs, $R_{\mathrm{C} 2}$ pedig a referenciavezeték ellenállását, ahogyan a 3.15. ábrán is látható. A kettő értéke a megvalósítástól függően (például két párhuzamos vagy koaxiális kábel használata esetén) közel egyezhet, de akár jelentősen el is térhet egymástól. Hasonlóan nem tekinthetjük biztosnak, hogy a megfigyelési pontokhoz rendelhető $q_{1}$ és $q_{2}$ értékek megegyeznek.

Könnyen látható, hogy a (3.42)-(3.45) egyenletek továbbra is érvényesek, ha $R_{c}$-t és $q$-t az alábbi összefüggések szerint adjuk meg:

$$
\begin{aligned}
& R_{\mathrm{C}}=R_{\mathrm{C} 1}+R_{\mathrm{C} 2}, \\
& q=\frac{q_{1} R_{\mathrm{C} 1}+q_{2} R_{\mathrm{C} 2}}{R_{\mathrm{C}}} .
\end{aligned}
$$

Így, a két modell között felírható kapcsolatot ismerve elegendő, ha 3.14. ábrán bemutatott rendszert vizsgáljuk a továbbiakban.

\subsubsection{Az abszolút biztonságosság zajra vonatkozó feltételei}

A vezetékellenállással kiegészített rendszer abszolút biztonságosságának zajparamétekre vonatkozó feltételeit a 3.3.2. fejezetben, az általánosított rendszer esetében alkalmazott eljárásunkhoz hasonlóan határozhatjuk meg. A (3.42)-(3.45) egyenletek alapján a 3.3. fejezet elején megfogalmazott három kritérium, azaz $V_{\mathrm{E}}$ és $I_{\mathrm{E}}$ varianciáinak és korrelációjának egyenlősége kifejezhető a feszültségzajok varianciáival. Természetesen, mivel ugyanazokból a kritériumokból indulunk ki, mint a 3.3.2 fejezetben, a feszültségzajoknak ez esetben is normális eloszlásúnak kell lennie.

A vezetéken mérhető áramerősség egyenlősége LH és HL állapotban a (3.42) és (3.44) egyenletek alapján:

$$
\frac{\left\langle V_{\mathrm{LA}}^{2}(t)\right\rangle+\left\langle V_{\mathrm{HB}}^{2}(t)\right\rangle}{\left(R_{\mathrm{LA}}+R_{\mathrm{HB}}+R_{\mathrm{C}}\right)^{2}}=\frac{\left\langle V_{\mathrm{HA}}^{2}(t)\right\rangle+\left\langle V_{\mathrm{LB}}^{2}(t)\right\rangle}{\left(R_{\mathrm{HA}}+R_{\mathrm{LB}}+R_{\mathrm{C}}\right)^{2}} .
$$

Hasonlóan, a vezetéken mérhető feszültség egyenlősége a két állapotban a (3.43) és (3.45) egyenletek alapján:

$$
\begin{aligned}
& \frac{\left(R_{\mathrm{HB}}+(1-q) \cdot R_{\mathrm{C}}\right)^{2} \cdot\left\langle V_{\mathrm{LA}}^{2}(t)\right\rangle+\left(R_{\mathrm{LA}}+q \cdot R_{\mathrm{C}}\right)^{2} \cdot\left\langle V_{\mathrm{HB}}^{2}(t)\right\rangle}{\left(R_{\mathrm{LA}}+R_{\mathrm{HB}}+R_{\mathrm{C}}\right)^{2}}= \\
& =\frac{\left(R_{\mathrm{LB}}+(1-q) \cdot R_{\mathrm{C}}\right)^{2} \cdot\left\langle V_{\mathrm{HA}}^{2}(t)\right\rangle+\left(R_{\mathrm{HA}}+q \cdot R_{\mathrm{C}}\right)^{2} \cdot\left\langle V_{\mathrm{LB}}^{2}(t)\right\rangle}{\left(R_{\mathrm{HA}}+R_{\mathrm{LB}}+R_{\mathrm{C}}\right)^{2}} .
\end{aligned}
$$


Végezetül, a két mennyiség korrelációjának LH és HL állapotban való egyenlősége a (3.42)-(3.45) egyenletek alapján:

$$
\begin{aligned}
& \left\langle\frac{V_{\mathrm{HB}}(t)-V_{\mathrm{LA}}(t)}{R_{\mathrm{LA}}+R_{\mathrm{HB}}+R_{\mathrm{C}}} \cdot \frac{\left(R_{\mathrm{HB}}+(1-q) \cdot R_{\mathrm{C}}\right) \cdot V_{L A}(t)+\left(R_{\mathrm{LA}}+q \cdot R_{\mathrm{C}}\right) \cdot V_{\mathrm{HB}}(t)}{R_{\mathrm{LA}}+R_{\mathrm{HB}}+R_{\mathrm{C}}}\right\rangle= \\
& =\left\langle\frac{V_{\mathrm{LB}}(t)-V_{\mathrm{HA}}(t)}{R_{\mathrm{HA}}+R_{\mathrm{LB}}+R_{\mathrm{C}}} \cdot \frac{\left(R_{\mathrm{LB}}+(1-q) \cdot R_{\mathrm{C}}\right) \cdot V_{\mathrm{HA}}(t)+\left(R_{\mathrm{HA}}+q \cdot R_{\mathrm{C}}\right) \cdot V_{\mathrm{LB}}(t)}{R_{\mathrm{HA}}+R_{\mathrm{LB}}+R_{\mathrm{C}}}\right\rangle .
\end{aligned}
$$

Az egyenlet bal oldalát tovább írva, és kihasználva, hogy a feszültségzajok független volta miatt a korrelációjuk nulla, a következő alakhoz jutunk:

$$
\begin{aligned}
& \left\langle\frac{\left(R_{\mathrm{LA}}+q R_{\mathrm{C}}\right) V_{\mathrm{HB}}^{2}(t)+R_{\mathrm{HB}} V_{\mathrm{HB}}(t) V_{\mathrm{LA}}(t)-\left(R_{\mathrm{LA}}+q R_{\mathrm{C}}\right) \cdot V_{\mathrm{HB}}(t) V_{\mathrm{LA}}(t)-\left(R_{\mathrm{HB}}+(1-q) R_{\mathrm{C}}\right) V_{\mathrm{LA}}^{2}(t)}{\left(R_{\mathrm{LA}}+R_{\mathrm{HB}}+R_{\mathrm{C}}\right)^{2}}\right\rangle= \\
& =\frac{R_{\mathrm{LA}}+q R_{\mathrm{C}}}{\left(R_{\mathrm{LA}}+R_{\mathrm{HB}}+R_{\mathrm{C}}\right)^{2}}\left\langle V_{\mathrm{HB}}^{2}(t)\right\rangle+\frac{R_{\mathrm{HB}}+(1-2 q) R_{\mathrm{C}}-R_{\mathrm{LA}}}{\left(R_{\mathrm{LA}}+R_{\mathrm{HB}}+R_{\mathrm{C}}\right)^{2}}\left\langle V_{\mathrm{HA}}(t) V_{\mathrm{LB}}(t)\right\rangle-\frac{R_{\mathrm{HB}}+(1-q) R_{\mathrm{C}}}{\left(R_{\mathrm{LA}}+R_{\mathrm{HB}}+R_{\mathrm{C}}\right)^{2}}\left\langle V_{\mathrm{LA}}^{2}(t)\right\rangle= \\
& =\frac{R_{\mathrm{LA}}+q R_{\mathrm{C}}}{\left(R_{\mathrm{LA}}+R_{\mathrm{HB}}+R_{\mathrm{C}}\right)^{2}}\left\langle V_{\mathrm{HB}}^{2}(t)\right\rangle-\frac{R_{\mathrm{HB}}+(1-q) R_{\mathrm{C}}}{\left(R_{\mathrm{LA}}+R_{\mathrm{HB}}+R_{\mathrm{C}}\right)^{2}}\left\langle V_{\mathrm{LA}}^{2}(t)\right\rangle .
\end{aligned}
$$

Hasonlóan eljárva az egyenlet jobb oldalával:

$$
\begin{aligned}
& \left\langle\frac{\left(R_{\mathrm{HA}}+q R_{\mathrm{C}}\right) V_{\mathrm{LB}}^{2}(t)+\left(R_{\mathrm{LB}}+(1-q) R_{\mathrm{C}}\right) V_{\mathrm{HA}}(t) V_{\mathrm{LB}}(t)-\left(R_{\mathrm{HA}}+q R_{\mathrm{C}}\right) V_{\mathrm{HA}}(t) V_{\mathrm{LB}}(t)-\left(R_{\mathrm{LB}}+(1-q) R_{\mathrm{C}}\right) V_{\mathrm{HA}}^{2}(t)}{\left(R_{\mathrm{HA}}+R_{\mathrm{LB}}+R_{C}\right)^{2}}\right\rangle= \\
& =\frac{R_{\mathrm{HA}}+q R_{\mathrm{C}}}{\left(R_{\mathrm{HA}}+R_{\mathrm{LB}}+R_{\mathrm{C}}\right)^{2}}\left\langle V_{\mathrm{LB}}^{2}(t)\right\rangle+\frac{R_{\mathrm{LB}}+(1-2 q) R_{\mathrm{C}}-R_{\mathrm{HA}}}{\left(R_{\mathrm{HA}}+R_{\mathrm{LB}}+R_{\mathrm{C}}\right)^{2}}\left\langle V_{\mathrm{HA}}(t) V_{\mathrm{LB}}(t)\right\rangle-\frac{R_{\mathrm{LB}}+(1-q) R_{\mathrm{C}}}{\left(R_{\mathrm{HA}}+R_{\mathrm{LB}}+R_{\mathrm{C}}\right)^{2}}\left\langle V_{\mathrm{HA}}^{2}(t)\right\rangle= \\
& =\frac{R_{\mathrm{HA}}+q R_{\mathrm{C}}}{\left(R_{\mathrm{HA}}+R_{\mathrm{LB}}+R_{\mathrm{C}}\right)^{2}}\left\langle V_{\mathrm{LB}}^{2}(t)\right\rangle-\frac{R_{\mathrm{LB}}+(1-q) R_{\mathrm{C}}}{\left(R_{\mathrm{HA}}+R_{\mathrm{LB}}+R_{\mathrm{C}}\right)^{2}}\left\langle V_{\mathrm{HA}}^{2}(t)\right\rangle .
\end{aligned}
$$

Végezetül a következő egyenlőségre jutottunk:

$$
\begin{aligned}
& \frac{R_{\mathrm{LA}}+q \cdot R_{\mathrm{C}}}{\left(R_{\mathrm{LA}}+R_{\mathrm{HB}}+R_{\mathrm{C}}\right)^{2}}\left\langle V_{\mathrm{HB}}^{2}(t)\right\rangle-\frac{R_{\mathrm{HB}}+(1-q) \cdot R_{\mathrm{C}}}{\left(R_{\mathrm{LA}}+R_{\mathrm{HB}}+R_{\mathrm{C}}\right)^{2}}\left\langle V_{\mathrm{LA}}^{2}(t)\right\rangle= \\
& =\frac{R_{\mathrm{HA}}+q \cdot R_{\mathrm{C}}}{\left(R_{\mathrm{HA}}+R_{\mathrm{LB}}+R_{\mathrm{C}}\right)^{2}}\left\langle V_{\mathrm{LB}}^{2}(t)\right\rangle-\frac{R_{\mathrm{LB}}+(1-q) \cdot R_{\mathrm{C}}}{\left(R_{\mathrm{HA}}+R_{\mathrm{LB}}+R_{\mathrm{C}}\right)^{2}}\left\langle V_{\mathrm{HA}}^{2}(t)\right\rangle .
\end{aligned}
$$

A (3.48), (3.49) és (3.53) egyenletek megadják az abszolút biztonságosságra vonatkozó három kritériumot az ellenállásértékekkel, a feszültségzajok varianciájával, illetve a vezetékellenállás és a $q$ relatív távolsággal kifejezve. Ezen egyenletrendszer alapján a négy ellenállás és az egyik feszültségzaj varianciájának tetszőleges értékéhez megadható a másik három feszültségzaj varianciája. $V_{\text {LA }}$ effektív értékét adottnak tekintve az egyenletrendszer megoldásával a (3.54)-(3.56) összefüggésekhez jutunk. 


$$
\begin{aligned}
& \frac{\left\langle V_{\mathrm{HB}}^{2}(t)\right\rangle}{\left\langle V_{\mathrm{LA}}^{2}(t)\right\rangle}=\frac{R_{\mathrm{LB}}\left(R_{\mathrm{HA}}+R_{\mathrm{HB}}+R_{\mathrm{C}}\right)-\left(R_{\mathrm{HA}}+R_{\mathrm{C}}\right) R_{\mathrm{HB}}-R_{\mathrm{HB}}^{2}}{R_{\mathrm{LA}}^{2}+R_{\mathrm{LB}}\left(R_{\mathrm{LA}}-R_{\mathrm{HA}}\right)+\left(R_{\mathrm{C}}-R_{\mathrm{HA}}\right) R_{\mathrm{LA}}-R_{\mathrm{C}} R_{\mathrm{HA}}}, \\
& \frac{\left\langle V_{\mathrm{LB}}^{2}(t)\right\rangle}{\left\langle V_{\mathrm{LA}}^{2}(t)\right\rangle}=\frac{R_{\mathrm{LB}}^{2}+R_{\mathrm{LB}}\left(R_{\mathrm{HA}}-R_{\mathrm{HB}}+R_{\mathrm{C}}\right)-\left(R_{\mathrm{HA}}+R_{\mathrm{C}}\right) R_{\mathrm{HB}}}{R_{\mathrm{LA}}^{2}+R_{\mathrm{LA}}\left(R_{\mathrm{HB}}-R_{\mathrm{HA}}+R_{\mathrm{C}}\right)-R_{\mathrm{HA}} R_{\mathrm{HB}}-R_{\mathrm{C}} R_{\mathrm{HA}}}, \\
& \frac{\left\langle V_{\mathrm{HA}}^{2}(t)\right\rangle}{\left\langle V_{\mathrm{LA}}^{2}(t)\right\rangle}=\frac{R_{\mathrm{HA}}^{2}+R_{\mathrm{LB}}\left(R_{\mathrm{HB}}+R_{\mathrm{HA}}+R_{\mathrm{C}}\right)+\left(R_{\mathrm{HA}}+R_{\mathrm{C}}\right) R_{\mathrm{HB}}+2 R_{\mathrm{C}} R_{\mathrm{HA}}+R_{\mathrm{C}}^{2}}{R_{\mathrm{LA}}^{2}+R_{\mathrm{LB}}\left(R_{\mathrm{LA}}+R_{\mathrm{HB}}+R_{\mathrm{C}}\right)+\left(R_{\mathrm{HB}}+2 R_{C}\right) R_{\mathrm{LA}}+R_{\mathrm{C}} R_{\mathrm{HB}}+R_{\mathrm{C}}^{2}} .
\end{aligned}
$$

Levonhatjuk tehát a következtetést, hogy a (3.54)-(3.56) egyenletek szerint megválasztott effektív értékű zajgenerátorokkal a kommunikáció abszolút biztonságos, azaz a vezetékellenállás okozta szivárgás az általános, négy tetszőleges értékű ellenállást tartalmazó rendszer esetében is teljes mértékben eliminálható. $V_{\mathrm{LA}}$ effektív értékének tetszőleges megválasztása lehetővé teszi Alice és Bob számára a megfelelő jelerősség biztosítását a kommunikáció során.

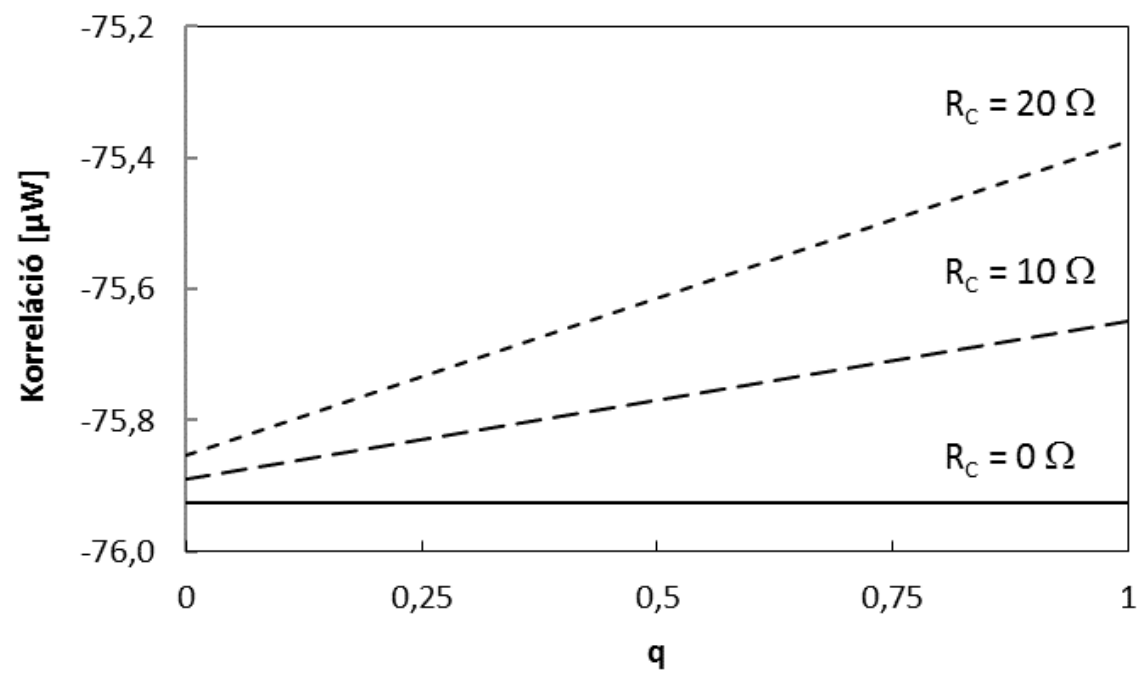

3.16. ábra: $V_{\mathrm{E}}$ és $I_{\mathrm{E}}$ korrelációja a $q$ megfigyelési pont függvényében, három különböző $R_{C}$ vezetékellenállás esetén. A korreláció a (3.53) egyenletnek megfelelően megegyezik LH és HL esetben. Az elrendezés komponenseinek értékei: $R_{\mathrm{HA}}=10 \mathrm{k} \Omega$, $R_{\mathrm{LB}}=5 \mathrm{k} \Omega, R_{\mathrm{LA}}=1 \mathrm{k} \Omega, R_{\mathrm{HB}}=9 \mathrm{k} \Omega, V_{\mathrm{LA}}=1 \mathrm{~V}$. $V_{\mathrm{HB}}, V_{\mathrm{LB}}$ és $V_{\mathrm{HA}}$ effektív értékei a (3.54)-(3.56) egyenletek alapján lettek beállítva.

Fontos kiemelni, hogy a (3.54)-(3.56) egyenletekben nem szerepel $q$, tehát a két kommunikáló félnek nem kell ismernie Eve megfigyelési pontját, a biztonságosság a vezeték teljes hosszán garantált. A 3.16. és 3.17. ábrán két különböző, aszimmetrikus konfiguráció esetében, három különböző vezetékellenállás értékre láthatjuk, hogy $V_{\mathrm{E}}$ és $I_{E}$ (3.53) egyenlet szerint kiszámítható korrelációja lineárisan változik Eve megfigyelési pontjának függvényében. A 3.16. ábrán vizsgált konfiguráció esetében nincs is olyan pont a vezeték teljes hosszán, ahol a korreláció nulla lenne, azonban ez 
- ahogyan a KLJN általánosításánál is láttuk a 3.3. fejezetben - nem is szükséges számunkra, az abszolút biztonságosság szempontjából a kulcs az, hogy a korreláció minden megfigyelési ponton egyenlő LH és HL esetben, amely a (3.53) egyenletnek megfelelően teljesül.

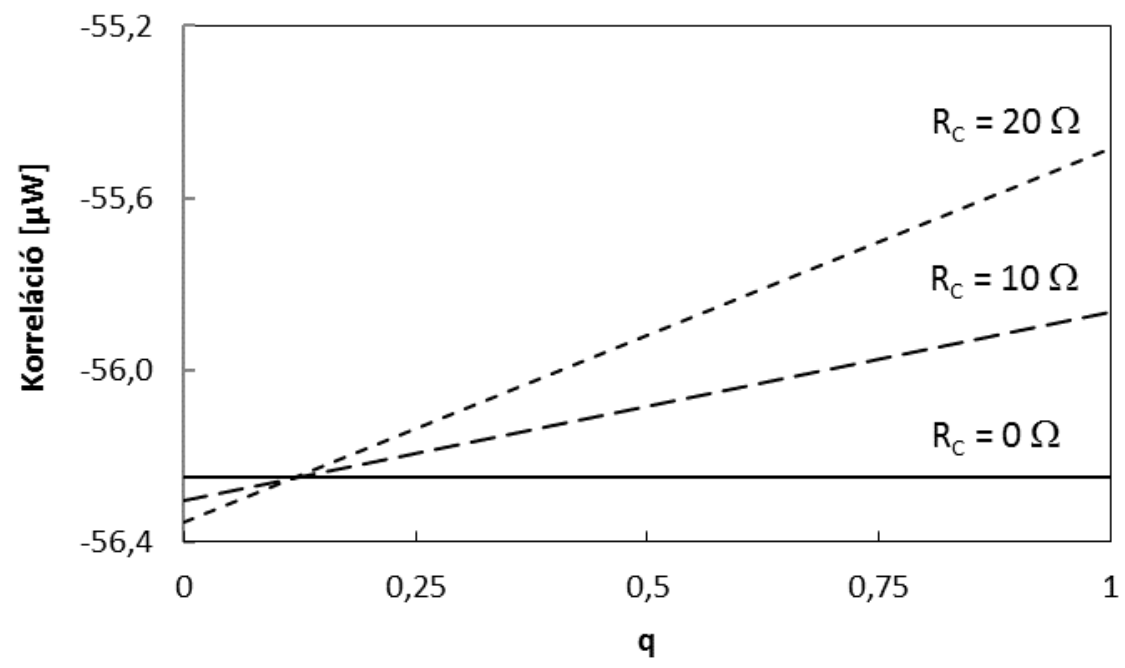

3.17. ábra: $V_{\mathrm{E}}$ és $I_{\mathrm{E}}$ korrelációja a $q$ megfigyelési pont függvényében, három különböző $R_{\mathrm{C}}$ vezetékellenállás esetén. A korreláció a (3.53) egyenletnek megfelelően megegyezik LH és HL esetben. Az elrendezés komponenseinek értékei: $R_{\mathrm{HA}}=9 \mathrm{k} \Omega$, $R_{\mathrm{LB}}=3 \mathrm{k} \Omega, R_{\mathrm{LA}}=1 \mathrm{k} \Omega, R_{\mathrm{HB}}=9 \mathrm{k} \Omega, V_{\mathrm{LA}}=1 \mathrm{~V}$. $V_{\mathrm{HB}}, V_{\mathrm{LB}}$ és $V_{\mathrm{HA}}$ effektív értékei a (3.54)-(3.56) egyenletek alapján lettek beállítva.

\subsubsection{Speciális eset: az eredeti KLJN rendszer}

$\mathrm{Az}$ eredeti KLJN rendszer az a speciális eset, amikor a szimmetrikus elrendezésből $\left(R_{\mathrm{LA}}=R_{\mathrm{LB}}=R_{\mathrm{L}}\right.$ and $\left.R_{\mathrm{HA}}=R_{\mathrm{HB}}=R_{\mathrm{H}}\right)$ következően, a vezetékellenállás figyelembevétele nélkül a vezetéken mérhető feszültség és áramerősség korrelációja nulla. Az eredmények alapján $R_{c}$ vezetékellenállás esetén is biztosítható az abszolút biztonságos kommunikáció, a zajgenerátorok effektív értékeit megadó (3.54)-(3.56) egyenletek ezen konfigurációra alkalmazva a következő alakra egyszerűsödnek:

$$
\begin{aligned}
& \frac{\left\langle V_{\mathrm{HB}}^{2}(t)\right\rangle}{\left\langle V_{\mathrm{LA}}^{2}(t)\right\rangle}=\frac{R_{\mathrm{H}}+\frac{R_{\mathrm{C}}}{2}}{R_{\mathrm{L}}+\frac{R_{\mathrm{C}}}{2}}, \\
& \frac{\left\langle V_{\mathrm{HA}}^{2}(t)\right\rangle}{\left\langle V_{\mathrm{LA}}^{2}(t)\right\rangle}=\frac{R_{\mathrm{H}}+\frac{R_{\mathrm{C}}}{2}}{R_{\mathrm{L}}+\frac{R_{\mathrm{C}}}{2}}, \\
& \left\langle V_{\mathrm{LB}}^{2}(t)\right\rangle=\left\langle V_{\mathrm{LA}}^{2}(t)\right\rangle .
\end{aligned}
$$


Látható, hogy a szimmetrikus elrendezésnek megfelelően a két oldalon lévő L és $\mathrm{H}$ állapotnak megfelelő feszültségzajok varianciája megegyezik, a vezetékellenállástól függetlenül. A (3.57) és (3.58) egyenletek összhangban állnak a Kish által megadott eliminációs eljárással, és igazolják az eredményt, miszerint ez a kompenzáció a vezeték teljes hosszán garantálja a kommunikáció biztonságosságát. Ezen egyenletek az eredeti modellre vonatkozó (3.12) skálázás szerint egy olyan szimmetrikus konfigurációnak felelnek meg, ahol az ellenálláspárok elemei a vezetékellenállás felével vannak megnövelve, vagy ahogy a fejezet elején értelmeztük, Eve a vezeték közepén $(q=0.5)$ mér. Ekkor az eredeti KLJN protokoll alapján $V_{\mathrm{E}}$ és $I_{\mathrm{E}}$ korrelációja nulla.

Amikor $q$ eltér 0.5-től - azaz Eve nem megfigyelési pontja nem a vezeték közepén van - $V_{\mathrm{E}}$ és $I_{\mathrm{E}}$ korrelációja nem nulla, ahogyan a 3.18. ábrán is látható.

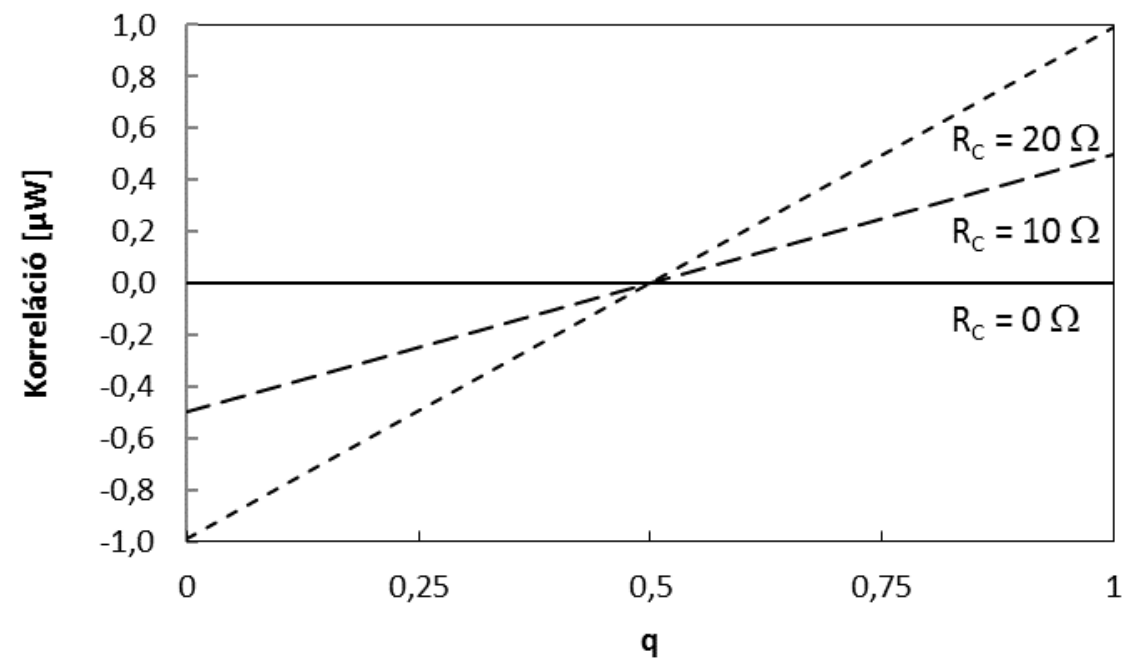

3.18. ábra: $V_{\mathrm{E}}$ és $I_{\mathrm{E}}$ korrelációja a $q$ megfigyelési pont függvényében, három különböző $R c$ vezetékellenállás esetén. A korreláció a (3.53) egyenletnek megfelelően megegyezik LH és HL esetben. Az elrendezés komponenseinek értékei: $R_{\mathrm{HA}}=9 \mathrm{k} \Omega$, $R_{\mathrm{LB}}=3 \mathrm{k} \Omega, R_{\mathrm{LA}}=1 \mathrm{k} \Omega, R_{\mathrm{HB}}=9 \mathrm{k} \Omega, V_{\mathrm{LA}}=1 \mathrm{~V}$. $V_{\mathrm{HB}}, V_{\mathrm{HA}}$ és $V_{\mathrm{LB}}$ effektív értékei a (3.57)-(3.59) egyenletek alapján lettek beállítva.

Ahogy látható, nem nulla értékű vezetékellenállás esetén $V_{\mathrm{E}}$ és $I_{\mathrm{E}}$ korrelálatlansága az eredeti rendszer esetén sem áll fent, hiszen ez csak a vezeték közepén teljesül (amely következik abból is, hogy minden más megfigyelési pont esetén egy aszimmetrikus rendszert vizsgálunk). Ugyanakkor, ahogy az aszimmetrikus elrendezések esetén is láttuk, és a 3.4.3. fejezetben bizonyítottuk, a korreláció a vezeték minden pontján egyenlő LH és HL esetben, azaz a kommunikáció abszolút biztonságos a vezeték teljes hosszán. 


\subsubsection{A gyakorlati megvalósítás numerikus szimulációja}

Ahogyan az előzőekben megmutattuk, a kommunikáló felek által használt ellenállások és a vezetékellenállás értékét, illetve a zajgenerátorok effektív értékét ismerve az abszolút biztonságos kommunikáció megvalósítható. Ennek demonstrálására a 3.3.3. fejezethez hasonlóan a vezetékellenállást figyelembe véve is meghatároztam numerikus szimulációval az Eve által mérhető statisztikai paraméterekre a BER értékét, egy aszimmetrikus konfiguráció esetén. Ahogyan a 3.2. táblázatban látható, az elméleti eredményeknek megfelelően egyik $R \mathrm{C}$ vezetékellenállás esetén sem tapasztalható információszivárgás.

\begin{tabular}{|c|c|c|c|}
\hline \multirow{2}{*}{$R \mathrm{C}[\Omega]$} & $\left\langle I_{\mathrm{E}}^{2}(t)\right\rangle$ & $\left\langle V_{\mathrm{E}}^{2}(t)\right\rangle$ & $\left\langle V_{\mathrm{E}}(t) I_{\mathrm{E}}(t)\right\rangle$ \\
\cline { 2 - 4 } & $B E R[\%]$ & $B E R[\%]$ & $B E R[\%]$ \\
\hline 20 & 49,987 & 49,893 & 49,938 \\
\hline 100 & 49,946 & 49,992 & 49,967 \\
\hline 200 & 49,973 & 49,967 & 49,978 \\
\hline
\end{tabular}

3.2. táblázat: A $V_{\mathrm{E}}$ és $I_{\mathrm{E}}$ varianciája és korrelációja alapján meghatározott $B E R$ értékek az általánosított, $R c$ ellenállású vezetékkel kiegészített rendszer esetén, $10^{6}$ bit átvitelének numerikus szimulációjával három különböző $R_{\mathrm{C}}$ értékre. Az elrendezés komponenseinek értékei: $R_{\mathrm{HA}}=10 \mathrm{k} \Omega, R_{\mathrm{LB}}=5 \mathrm{k} \Omega, R_{\mathrm{LA}}=1 \mathrm{k} \Omega, R_{\mathrm{HB}}=9 \mathrm{k} \Omega, V_{\mathrm{LA}}=1 \mathrm{~V} . V_{\mathrm{HB}}, V_{\mathrm{LB}}$ és $V_{\text {HA }}$ effektív értékei a (3.54)-(3.56) egyenletek alapján lettek beállítva.

A BER értékek meghatározása a 3.3.3. fejezetben bemutatott módon, ebben az esetben is $10^{6}$ bitátvitel szimulációjával történt, egy bitátvitel során pedig a feszültségzajok 1000 pontból álltak. Az adatpontok száma megfeleltethető a 3.1.1. fejezetben tárgyalt statisztikailag független mérési pontok számának $(k)$, mely KLJN protokoll gyakorlati megvalósítása során egy nagyságrenddel kisebb értékek esetén is megfelelően alkalmazhatónak bizonyult [49]. Értelemszerűen, ha Alice és Bob ennél több ideig tartja fent a rendszer egy állapotát, Eve nagyobb adathalmazzal, és így pontosabb információval rendelkezhet. Mint láthatjuk, Eve a 3.3.3. és e fejezetben használt, a gyakorlati megvalósításhoz szükséges időnél egy nagyságrenddel nagyobb bitátviteli idő alatt sem jut semmilyen hasznos információhoz a bitek értékét illetően.

A vezetékellenállás kiegészített, általános rendszer numerikus szimulációjához LabVIEW környezetben készített szoftverek letölthetőek, továbbá az eredményeket videókkal is illusztráltam [79].

\section{Az alkatrészek pontatlanságának hatása}

Ha a zajgenerátorok effektív értékét a (3.54)-(3.56) egyenletek alapján nem a pontos értékeket használva állítjuk be, információszivárgás lép fel. $\mathrm{Az}$ ellenállásértékek illetve a zajgenerátorok effektív értékének pontatlansága és az 
információszivárgás mértéke közötti kapcsolatot numerikus szimulációkkal vizsgáltam egy aszimmetrikus elrendezés esetén (a konfiguráció paraméterei az ábrafeliratokban találhatóak).

A vizsgálat során a zajgenerátorok effektív értékei az adott komponensről a

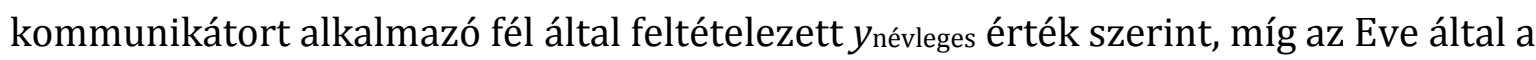
vezetéken mérhető $V_{\mathrm{E}}(t)$ és $I_{\mathrm{E}}(t)$ jelek az $y_{\text {valós értéket felhasználva kerültek }}$ meghatározásra. Az információszivárgást egy komponens e két értékének relatív eltérésének függvényében vizsgáltam, miközben a többi komponens értéke nem változott. Az információszivárgás mértéke egy adott komponens vizsgálata során a korábbiakban ismertetett elméleti eredményeknek megfelelően nem függött Eve megfigyelési pontjától.

Ahogyan a 3.19. ábrán látható az $R_{\mathrm{HB}}-5 \%$-os relatív hibája esetén, a $B E R$ értéke jelentősen függ Eve mérési idejétől, azaz hogy hány független adatpontra $(k)$ készítheti el statisztikáit.

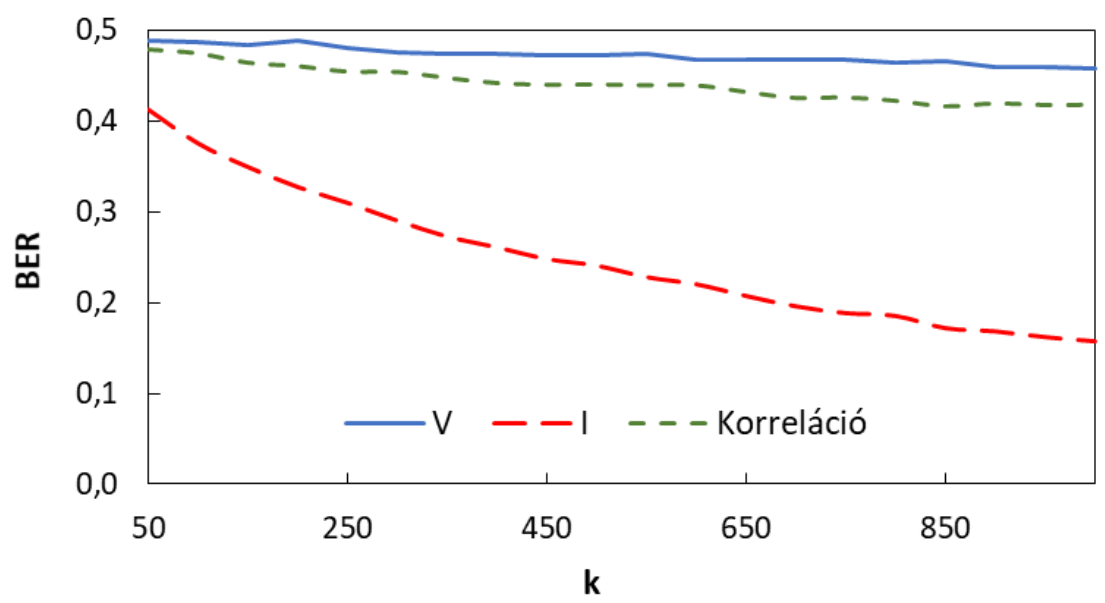

3.19. ábra: A $V$ E és IE varianciái és korrelációja alapján meghatározott $B E R$ értékek az $R$ HB valós és névleges értéke közötti -5\%-os relatív eltérés esetén az egy bit átviteléhez használt $k$ statisztikailag független adatpontok számának függvényében, 20000 bit átvitele esetén. Az elrendezés komponenseinek (névleges) értékei egyeznek a 3.2. táblázatban jelzettekkel, továbbá $R_{C}$, névleges $=200 \Omega$.

Bár az előbbiek alapján úgy tűnhet, hogy minél kevesebb adatpont felhasználásáa szükséges a maximális kommunikációs sebesség eléréséhez, a fejezetben bemutatott, általam bevezetett általános rendszer numerikus vizsgálatával Mingesz Róbert és Bors Noémi megmutatta, hogy egy adott elrendezés esetén létezik egy optimum $k$ értékére [4]. Bár minél kevesebb adatpont szükséges, annál rövidebb ideig tart egy bit átvitele, és Eve-nek is annál kevesebb információ áll rendelkezésére, Alice és Bob is a mért értékek statiszikája alapján különböztetheti meg a biztonságos biteket az LL és HH bitektől, melynek pontosságához a mérési idő növelése szükséges. 
A fejezetben tárgyalt elrendezés esetén ez 260 pontnak adódott, így a következőkben bemutatott numerikus vizsgálataimat ekkora méretű zajcsomagokra végeztem el.

A 3.20. ábrán láthatjuk a négy ellenállás pontatlanságának hatását. Megfigyelhető, hogy az aszimmetrikus elrendezésnek köszönhetően mind a négy ellenállás hatása különböző a $B E R$ értékekre, továbbá a kommunikátorban beállított $\mathrm{L}$ állapothoz tartozó ellenállások pontatlansága kisebb mértékű információt idéz elő, mint a $\mathrm{H}$ állapothoz tartozó ellenállsoké. Míg $R_{\mathrm{LA}}$ esetében a kapcsolat közel lineáris mindhárom $B E R$ értékkel, a magas értékű ellenállások névleges és valós értéke közötti 5\%-os eltérés a BER értékének közel 20\%-is csökkenését okoz az $I_{E}$ varianciája alapján.
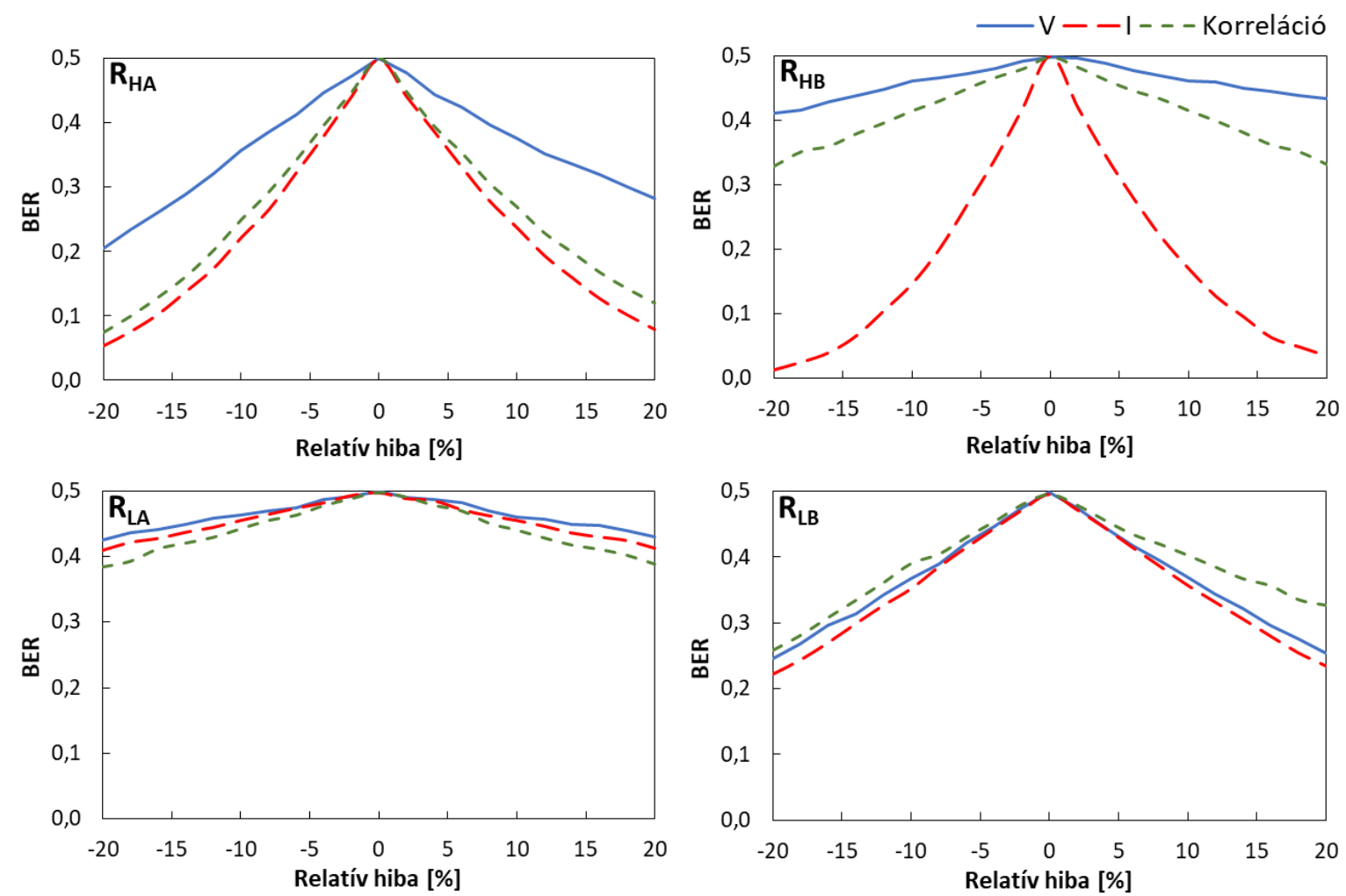

3.20. ábra: A $V_{\mathrm{E}}$ és $I_{\mathrm{E}}$ varianciái és korrelációja alapján meghatározott $B E R$ értékek az ellenállások relatív hibájának függvényében 20000 bit átvitele esetén. Az elrendezés komponenseinek (névleges) értékei egyeznek a 3.2. táblázatban jelzettekkel, továbbá $R$ C, névleges=200 $\Omega$. Egy bit átviteléhez használt adatpontok száma: 260 .

Hasonló képet mutat a 3.21. ábrán a feszültségzajok generálásának hibája okozta információszivárgás. Mind a négy zajgenerátor esetében található olyan mennyiség, melynek statisztikája igen érzékeny az effektív érték pontosságára. A (3.54)-(3.56) egyenletek különböző alakjának megfelelően igen különböző kapcsolat figyelhető meg a feszültségzajok varianciájának pontatlansága és az Eve által mért mennyiségek statisztikája között; míg például $V_{\mathrm{HB}}$ esetében a feszültség alapján számított $B E R$ alig csökken a vizsgált tartományon, $V_{\mathrm{LA}}$ esetében annak 5\%-os hibája esetén $25 \%$ körüli értékre csökken. 
Természetesen a komponensek pontatlansága és az információszivárgás közötti kapcsolat függ a vizsgált konfigurációtól is, azonban az eredmények mindenképpen demonstrálták számunkra, hogy a rendszer igen érzékeny az abszolút biztonságosság feltételinek megfelelő értékektől való eltérésre.

Ezen alkatrészek a két kommunikáló fél birtokában vannak, így valós esetben igen pontosan mérhetők, és a rendszer általánosításának köszönhetően a zajgenerátorok finomhangolásával az információszivárgás tetszőlegesen csökkenthető.
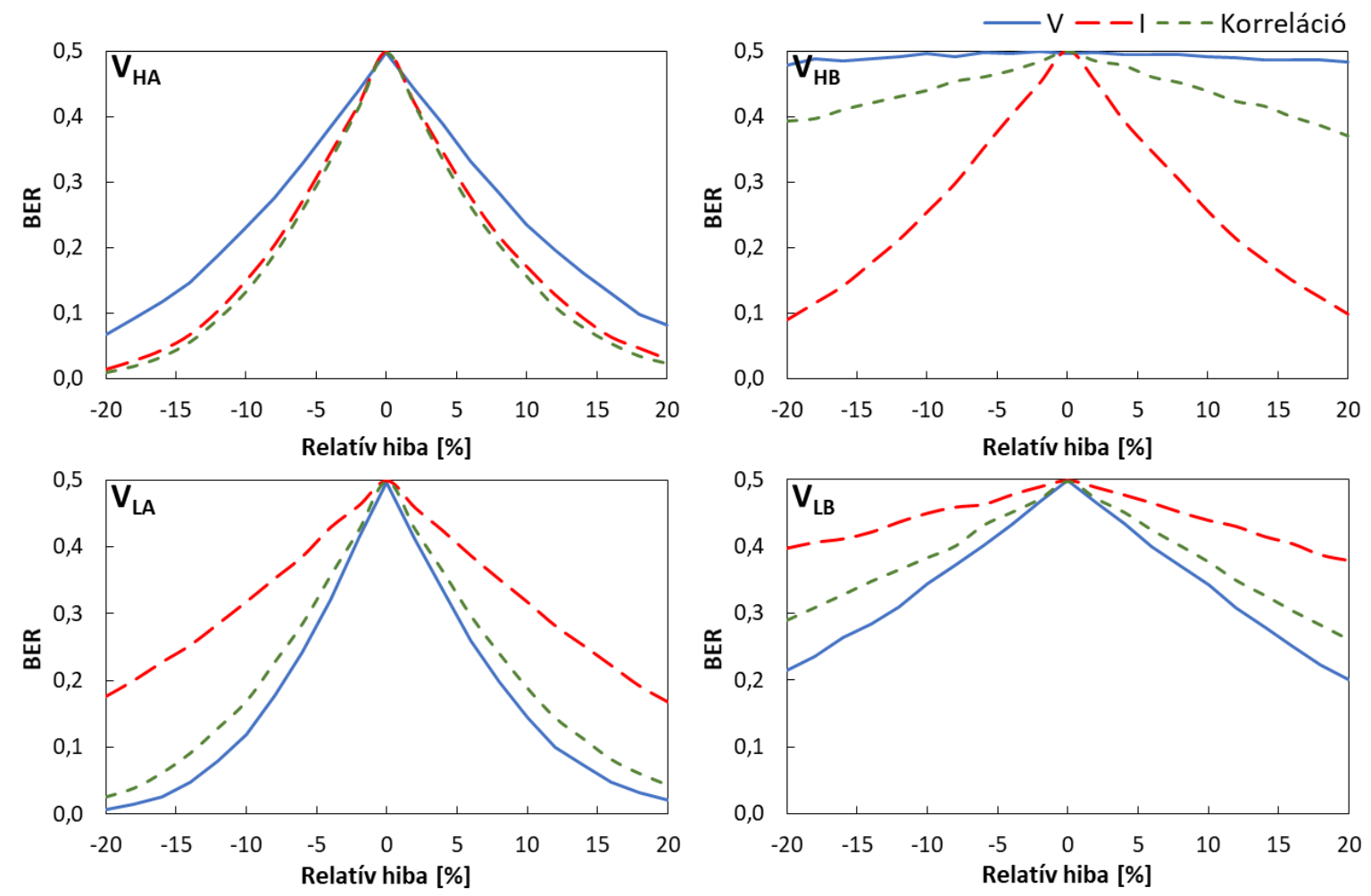

3.21. ábra: A $V_{\mathrm{E}}$ és $I_{\mathrm{E}}$ varianciái és korrelációja alapján meghatározott $B E R$ értékek a zajgenerátorok relatív hibájának függvényében, 20000 bit átvitele esetén. Az elrendezés komponenseinek értékei egyeznek a 3.2. táblázatban jelzettekkel, továbbá $R$ c, névleges $=200 \Omega$. Egy bit átviteléhez használt adatpontok száma: 260 .

Jóval nagyobb mértékű pontatlanság adódhat a kommunikációs vezeték ellenállásának értékében, mely Eve számára könnyebben hozzá is férhető. Azonban, ahogyan a 3.22. ábrán látható, a vezetékellenállás értékének pontatlan ismerete igen kis mértékben befolyásolja a $B E R$ értékeket, jelentős információszivárgás csak $R \mathrm{C}$ értékének többszöröseinél jelentkezik, mely kedvező tulajdonság a gyakorlati implementáció szempontjából. 


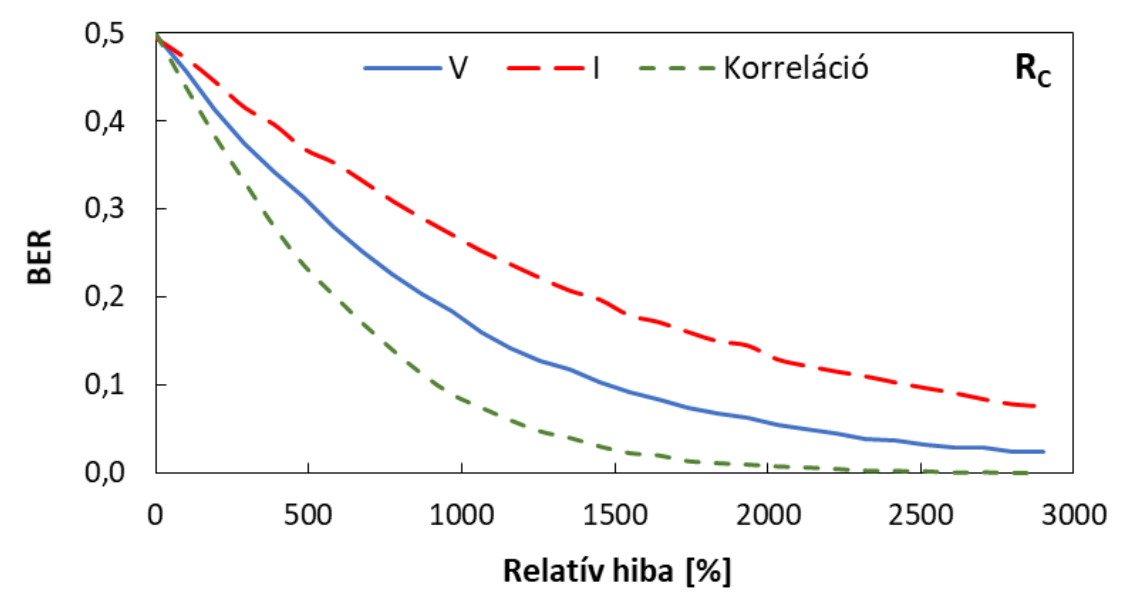

3.22. ábra: A $V_{\mathrm{E}}$ és $I_{\mathrm{E}}$ varianciái és korrelációja alapján meghatározott $B E R$ értékek az $R_{C}$ vezetékellenállás relatív hibájának függvényében, 20000 bit átvitele esetén. Az elrendezés komponenseinek értékei egyeznek a 3.2. táblázatban jelzettekkel, továbbá $R$ c, névleges=200 $\Omega$. Egy bit átviteléhez használt adatpontok száma: 260 .

\subsubsection{Az eredmények rövid összegzése és a rendszer előnyei}

Az előzőekben bemutattuk, hogy az abszolút biztonságosság az eddigi KLJN rendszereknél jelentősen kevesebb megkötés esetén is biztosítható. A rendszer négy tetszőleges ellenállás és nem nulla értékű vezetékellenállás esetén is a kommunikációs csatorna teljes egészén abszolút biztonságos, melyhez levezettük a szükséges, zajparaméterekre vonatkozó feltételeket. Az eredmények alapján látható, hogy a vezeték különböző pontjain eltér a feszültség és áramerősség korrelációjának értéke, azonban biztosítható, hogy ez megegyezzen az LH és HL esetekben. Ezzel értelmeztük a Kish által az eredeti rendszerre megadott kompenzációs eljárás mérési ponttól való függetlenségét [56]; a korreláció a szimmetrikus elrendezés esetén is csupán a vezeték közepén nulla, azonban semmilyen más ponton sem megkülönböztethető a rendszer két állapota. Az eredmény kiemelten fontos a gyakorlati megvalósítás szempontjából, hiszen a két kommunikáló fél az általuk használt összes szükséges komponens értékét ismerve, azonban Eve megfigyelési pontjától függetlenül beállíthatják a (3.54)-(3.56) formulák alapján a zajgenerátorok biztonságossághoz szükséges effektív értékét.

Ehhez mindössze a komponensek pontos értékét kell ismerni. Ezen ismeretek pontatlansága információszivárgást okoz, melynek mértékét numerikus szimulációkkal vizsgáltam. Az eredmények alapján jól látható, hogy a rendszer igen érzékeny a (3.54)-(3.56) egyenlekben szereplő, illetve azoknak megfelelő értékek pontosságára.

Azonban, ahogyan az általánosított rendszer előnyeinél is említésre került, a gyakorlati alkalmazásokhoz módosított rendszer esetében is igaz, hogy Alice és Bob könnyen módosíthatja - akár folyamatosan - a zajgenerátorainak effektív értékét úgy, hogy az információszivárgást eliminálja. Ehhez csupán meg kell mérnie a 
kommunikátorában található komponenseinek aktuális értékét (melyet az alkatrészek toleranciájánál nagyságrendekkel pontosabban meg tud tenni), hiszen az eredeti, szimmetriát megkövetelő KLJN elrendezéssel ellentétben - tetszőleges ellenállásértékekre biztosítható a biztonságos kommunikáció a zajgenerátorok megfelelő hangolásával. Ezen túlmenően, akár komponensek értékének pontos ismerete nélkül, a vezetéken mérhető feszültség és áramerősségértékekből is vonhat le következtetést a hiba kompenzálására.

A 3.23. ábrán látható egy Alice és Bob által alkalmazható kommunikátor sematikus rajza, ahol zajgenerátort egy digitális-analóg konverter (DAC) valósítja meg, mellyel a feszültségzajok varianciája igen nagy pontossággal állítható és szükség esetén kailbrálható.

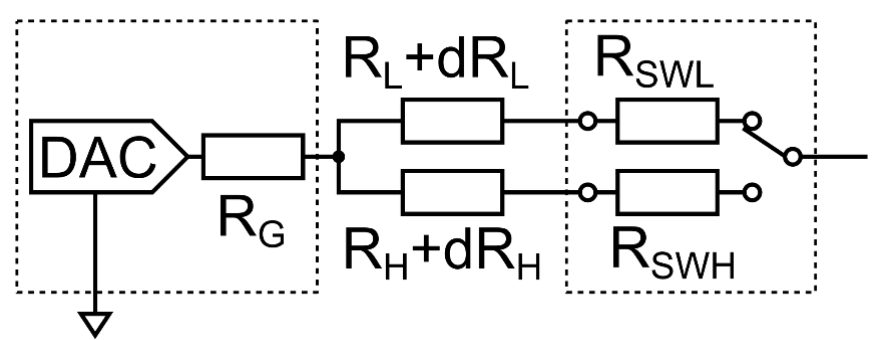

3.23. ábra: Egy KLJN kommunikátor sematikus rajza a komponensek ellenállásainak figyelembevételével.

A sematikus ábrán figyelembe vettük a DAC kimenő ellenállását $\left(R_{\mathrm{G}}\right)$, a két állapot közötti kapcsoló parazitaellenállásait ( $R$ swL és $R_{S w H}$ ) és az $R_{\mathrm{L}}$ és $R_{\mathrm{H}}$ ellenállások ideálistól való eltérését ( $d R_{\mathrm{L}}$ és $\left.d R_{\mathrm{H}}\right)$. Ekkor a KLJN rendszerben a kommunikáló fél által a vezetékre kapcsolt ellenállások valós értéke $\mathrm{L}$ esetben $\left(R_{\mathrm{L} \text {,valós }}\right)$ :

$$
R_{\mathrm{L}, \text { valós }}=R_{\mathrm{L}}+d R_{\mathrm{L}}+R_{\mathrm{G}}+R_{\mathrm{SWL}}
$$

H esetben $\left(R_{\mathrm{H}, \mathrm{való}}\right)$ :

$$
R_{\mathrm{H}, \text { valós }}=R_{\mathrm{H}}+d R_{\mathrm{H}}+R_{\mathrm{G}}+R_{\mathrm{SwH}} \text {. }
$$

Ahogy említettük, a kommunikáló felek az egyenletekben szereplő mennyiségeket akár működés közben, valós időben is folyamatosan monitorozhatják, így a valós ellenállásértékkel a (3.39)-(3.41) egyenletekbe behelyettesítve az abszolút biztonságos kommunikációnak megfelelő értékekre hangolhatják a zajgenerátorokat. A 3.23. ábrán látható, hogy egy DAC is elegendő a feszültségzajok elóállítására, hiszen az L és H esetben szükséges effektív érték beprogramozható.

$\mathrm{Az}$ alkatrészek hőmérsékletfüggése vagy mobil kommunikátorok esetén a kommunikációhoz használt különböző vezetékek alkalmazásonkénti cseréje mind olyan körülményt jelentenek, melyek információszivárgást okozhatnak, azonban a bemutatott rendszer esetében a biztonságosság az ellenállásméréssel (vagy a 
vezetéken történő méréssel) és zajgenerátorok hangolásával javítható, mértékét pedig kizárólag ezen műveletek pontossága befolyásolja. A két fél a folyamatos méréseit on-line meg is oszthatja egymással a KLJN protokoll részét képező autentikált, publikus csatornán, ezzel az információszivárgás automatikus csökkentése is lehetővé válik.

A 3.4. fejezetben bemutatott eredményeket az értekezés 3. tézispontja foglalja össze. 



\section{VERSENYKAJAK MOZGÁSJELEINEK FLUKTUÁCIÓANALÍZISE}

Az eddigiekben a zajokat speciális tulajdonságaik miatt tudatosan alkalmaztuk, azonban számos folyamat esetén egy mért mennyiség véletlenszerű fluktuációja is hasznos lehet számunkra, hiszen információt hordozhat a vizsgált rendszerről. Rendkívül változatos jelenségek esetében is találkozhatunk a zajok információforrásként való alkalmazásával, melyek egy fontos osztályát képezik a periodikus folyamatok.

E folyamatok lehetnek inherensen periodikusak, mint például a szívverésünk, vagy kialakulhatnak egy periodikus gerjesztés hatására, ahogyan a Föld felszínén mérhető hőmérséklet is változik annak forgásából és mozgásából adódóan. Mesterségesen létrehozott rendszerek, többek között a mechanikus gépek vagy mechatronikai rendszerek is rendelkeznek általában periodikusan mozgó alkatrészekkel. Számos esetben az ezek működésében fellépő determinisztikus vagy véletlenszerű változások informatívak lehetnek a vizsgált rendszer helyes működésével kapcsolatban, jelezhetik annak minőségét, indikálhatják bizonyos hibák, diszfunkciók jelenlétét vagy akár előre is jelezhetik a meghibásodást. Ebből következően mind az inherensen periodikus, mind a periodikusan gerjesztett rendszerek működése során megfigyelhető zaj felhasználható diagnosztikai eszközként, információforrásként is. Erre számos különböző diszciplina esetén találhatunk példát, mint például a szívritmus variabilitása [28], a vezényelt légzés során megfigyelhető hemodinamikai szabályzás [82], az emberi járás egyenletessége [27], a napi aktivitás ritmusa [83-85], a napi hőmérsékletingadozás [86, 87], változócsillagok periódusfluktuációi [24] vagy az indukciós motorok diagnosztikája $[25,26]$. Érdemes megjegyezni, hogy nem minden esetben a kisebb mértékű zaj jelenti a vizsgált rendszer megfelelőbb működését, a szívritmus túl kicsi ingadozása például egy lehetséges szívbetegséget jelezhet előre [28]. A következőkben a periodikus folyamatok esetén megfigyelhető zajra periódusfluktuációként 
hivatkozunk, mely jelentheti a periódusidő - az előbbi példánál maradva a szívritmus - vagy egy, a periódust jellemző mennyiség - például a szívciklushoz tartozó vérnyomásmaximum - ingadozását is.

Az említett példákhoz hasonlóan számos sportág esetében is periodikus mozgás végrehajtása szükséges, így a sportoló célja az egy ütemhez tartozó mozdulatsor optimális kivitelezése mellett annak egyenletes megismétlése is. Ez igaz többek között a kajak-kenu sport esetében az evezésre is. A Zaj és nemlinearitás kutatócsoport tagjaként részt vettem a EDF Démász Szeged Vízisport Egyesület, a Szegedi Tudományegyetem és a DEAK Kooperációs Nonprofit Zrt. által 2010-ben közösen indított, „Kajak-kenu teszter” fejlesztését célzó projektben. Feladatunk egy olyan mérőeszköz és hozzá tartozó szoftver fejlesztése volt, melyek a kajak mozgásjelei alapján meghatározott, a sportolók teljesítményét jellemző, egyszerűen értelmezhető mérőszámok és trendgörbék segítségével segítik az edzők és versenyzők munkáját a mindennapi edzések során. A mérések kivitelezését, a mozgásjelek analízisét, a szükséges jelfeldolgozó és indikátorokat meghatározó algoritmusokat Makan Gergellyel készítettük el LabVIEW környezetben, mely munkából diplomamunkáinkat is készítettük, majd a mérőrendszerrel elért eredmények publikálásra is kerültek [88, 89, 9]. A mozgásjelekhez, illetve azok periódusait jellemző mennyiségekhez kapcsolódó vizsgálataim során összefüggés mutatkozott azok egyenletessége és a versenyzők technikai képzettsége között, így doktori tanulmányaim egyik témaköre ezen mozgás periódusfluktuációinak elemzése lett.

Egy sportoló aktuális teljesítményét számos tényező befolyásolhatja, mint például a fizikai és mentális állapot, időjárás, versenydrukk vagy akár a szurkolók biztatása. Továbbá, még az ideálisan megvalósított evezések összehasonlítása is igen nehéz, hiszen lényegesen különböző technikával evező versenyzők között is néha csak századmásodpercek döntenek egy verseny során, azaz közös, optimális technika sem hatátorzható meg. Ez alapján könnyen belátható, hogy a bevezetésre kerülő indikátoroktól, melyek a technikai megvalósítás egy aspektusát vizsgálják, a teljesítmény egyértelmű leírását nem várhatjuk el. Mindazonáltal, a következőben bemutatásra kerülő, periódusfluktuációkon alapuló újfajta értékelés eredményei alapján a megközelítés igen sok lehetőséget rejt magában, akár további sportágak vagy orvosi vizsgálatok során mért mozgásjelek esetén is. A fluktuációk vizsgálata során továbbá egy, az egyes periódusok detektálását nélkülöző spektrális módszert is bevezettem, az ezáltal meghatározott indikátorok pedig hasonlóan biztató eredménnyel szolgáltattak, így az a mozgásjeleken túl számos periodikus jel (például kardiológiai jelek) vizsgálata esetén is előremutatónak bizonyulhat.

A következőkben a kajakos sportolók mozgásjeleinek mérését és klasszikus megközelítésű kiértékelését tárgyaló irodalom, illetve mérőrendszerünk rövid ismertetése után a periódusfluktuációk időbeli és spektrális vizsgálatával elért 
eredményeimet mutatom be. Végül az ezen vizsgálatok alapján felmerülő nyitott kérdések és további lehetőségek kerülnek tárgyalásra.

\subsection{A mozgásjelek mérése és általános jellemzése}

A versenykajak megfelelő előrehaladásához a sportoló által precízen végrehajtott komplex mozdulatsor szükséges, az ebben történő hiba a menetiránytól eltérő elmozdulást és így többlet energiadisszipációt eredményez. A mozdulatsor alapjait természetesen a kajakozás módszertana jól meghatározza [90], ugyanakkor, többek között a sportolók eltérő testfelépítéséből és a különféle versenystratégiákból adódóan igen különböző evezési technikákat is megfigyelhetünk a sikeres versenyzőknél.

Az optimális evezés vizsgálata történhet elméleti úton is, a mozgás biofizikai modellezésével és a fellépő erők leírásával [91-94], azonban a teljes, komplex mozgás szimulációja a hajóra ható közegellenállási erők figyelembevételével gyakorlati szempontból nem célravezető. A kajak mozgásjeleinek mérése alapján a mozgás rekonstruálása a mérések pontatlanságából kifolyólag ugyancsak nem lehetséges. Ugyanakkor az említett mennyiségek mérése és a jelek értelmezése mind a technika kialakítása, a mozgás optimalizálása, hibák detektálása, mind a sportoló teljesítményének vizsgálata kapcsán fontos segítséget nyújtanak a videós elemzéseken túl, így több évtizede az élsport megkerülhetetlen részét képezik.

A mozgás analízise mellett értelemszerűen nagyon fontos a sportolók teljesítményének fiziológiai vizsgálata is. A terhelés közben mért élettani jelek, pulzusszám, tejsavszint, oxigénfelvétel és további paraméterek segítenek az állóképesség mérésében, a fizikai állapot napi követésében, a megfelelő edzésprogram megtervezésében, továbbá - például az úgynevezett aneorob küszöb meghatározásával - az optimális technika és versenystratégia kialakításában [93102]. Ezen fiziológiai paraméterek monitorozása sok esetben a kajakozást szimuláló ergométer használata közben történik, mely edzéseszközzel a sportoló által befektett teljesítmény is mérhető $[93,95,100,101]$. Bár az eszközök fejlődésével a lapátra ható erők egyre pontosabban szimulálhatóak, továbbá a beépített szenzoroknak köszönhetően az evezés néhány technikai jellemzője is mérhető, a valós, vízen történő evezés során jóval több hatás éri a kajakot, melyek befolyásolják a sportoló által végrehajtandó mozdulatsort is, a versenyzőnek pedig jóval több mindenre kell figyelnie, ez pedig kihatással van a teljesítményére. Ebből következően a vízen történő evezések mérése jóval több és pontosabb információt adhat a kajakos teljesítményéről, sőt, akár a versenyeken való evezések is kiértékelhetővé válhatnak.

Az utóbbi évtizedekben történt nagy ütemű technikai fejlődésnek köszönhetően elérhetővé váltak az evezés értékeléséhez szükséges mennyiségek mérésére szolgáló szenzorok, mikroelektronikai alkatrészek, majd adatgyűjtő eszközök, így lehetővé vált 
a nyíltvizi evezések során mért különféle jelek vizsgálata és értelmezése. Elsőként a 80-as években lapátra helyezett nyúlásmérő bélyeggel mérték az evezések során fellépő lapáterőket [92, 103], majd a kompakt gyorsulásmérők és később további inerciaszenzorok megjelenésével a kajak és sportolók mozgása is vizsgálhatóvá vált.

Az olyan, evezést jellemző általános paraméterek, mint a csapásszám, két kéz húzása közötti aszimmetria, átlagsebesség, a húzás impulzusa és egy húzás szakaszait jellemző idők a mozgásjelekből megállapíthatóak, egy edzés vagy pályaevezés során nyomonkövethetőek [92, 94, 104-107]. Az optimális evezés megállapításához a közben mért gyorsulás-, szögsebesség- és húzáserőjelek alakjából számos tanulmány vont le következtetéseket [105, 106, 108-115]. A húzás közben történő hirtelen változásokból, illetve a menetiránytól eltérő irányban mért gyorsulás és giroszkópjelekből lehetséges a kajak nem optimális elmozdulásaira vagy akár a mozdulatsorban fellépő hibára következtetni, az átlagolt jelalakok elemzése továbbá segíthet akár egy kajak négyes megfelelő összeállításában is [105]. Ugyanakkor, ahogy korábban említésére került, igen különböző evezési technikák is lehetnek eredményesek, így az optimális jelalak meghatározása egy automatizált elemzéshez nem lehetséges, a mozgás értékeléséhez a jelek értő és részletes analízise szükséges.

Az utóbbi két évtizedben számos, kifejezetten az edzéseket segítő mérőműszer is megjelent a kereskedelmi forgalomban. A mozgás mérésére a DigiTrainer magyar fejlesztésű rendszer háromtengelyű gyorsulászenzort és GPS-t használ [114, 116], a Minimax B4 eszköz emellett tartalmaz háromtengelyű giroszkópot és magnetométert is [117], míg az Excalibur lapát nyúlásmérő bélyeggel méri a lapátban ébredő erőt [115]. Az előbbi kettőhöz pulzusmérésre alkalmas mellkaspánt is kapcsolható, továbbá számos kényelmi funkció elérhető, mint például az általános paraméterek valós idejű kijelzése okostelefonon, laptopon vagy speciális kijelzőn. Az eszközök az előbbiekben említett általános evezési paramétereket, a mozgásjeleket, a billegés mértékét és az átlagolt jelalakokat jelenítik meg a felhasználó számára.

A közreműködő edzők és sportolók tapasztalata szerint a mindennapi edzésen, ahol egy trénernek számos kajakosra kell figyelnie, az említett kényelmi funckiók különösebben nem mutatkoznak hasznosak, a mozgásjelek értelmezésére pedig nincs idejük és lehetőségük. A célkitűzésünk így olyan további, könnyen értelmezhető mérőszámok keresése volt, amelyek segítik a sportoló aktuális teljesítményének mérését az evezés technikai kivitelezésének jellemzésével.

Mivel az említett eszközök által szolgálatott jelek nem minden esetben hozzáférhetőek, illetve nem volt garantált, hogy megfelelőek a célul kítűzött, részletes analízishez, egy egyedi fejlesztésű mérőműszer készült el, amely állítható módon, az említett eszközök 30-100 Hz-es mintavételi frekvenciájánál akár jóval nagyobb rátával méri az mozgásjeleket, illetve számos, esetlegesen a későbbiekben felmerülő további periféria is csatlakoztatható hozzá. 


\subsubsection{Mérőrendszer}

Méréseinket az előbbi megfontolások alapján, a „Kajak-kenu teszter” projekt keretében egyedi fejlesztésű eszközünkkel végeztetük el, melynek utolsó, Gingl Zoltán, Mingesz Róbert, Mellár János és Kocsis Péter által fejlesztett prototípusa 2011 tavaszán 5 példányban készült el.

Ahogyan a 4.1. ábrán látható, a műszer egy C8051F581 mikrovezérlőn alapul, amely a beérkező analóg jeleket egy 12-bites analóg-digitál konverterrel digitalizálja. A mikrokontrolleren futó beágyazott szoftver végzi a nyers szenzorjelek mérését az előzetesen beállított konfigurációs paraméterek alapján, biztosítja az optimális akkumulátor használatot és kezeli a mérés indítását és leállítását vezérlő nyomógombot, továbbá hang és fényjelzéssel jelzi a műszer aktuális állapotát.

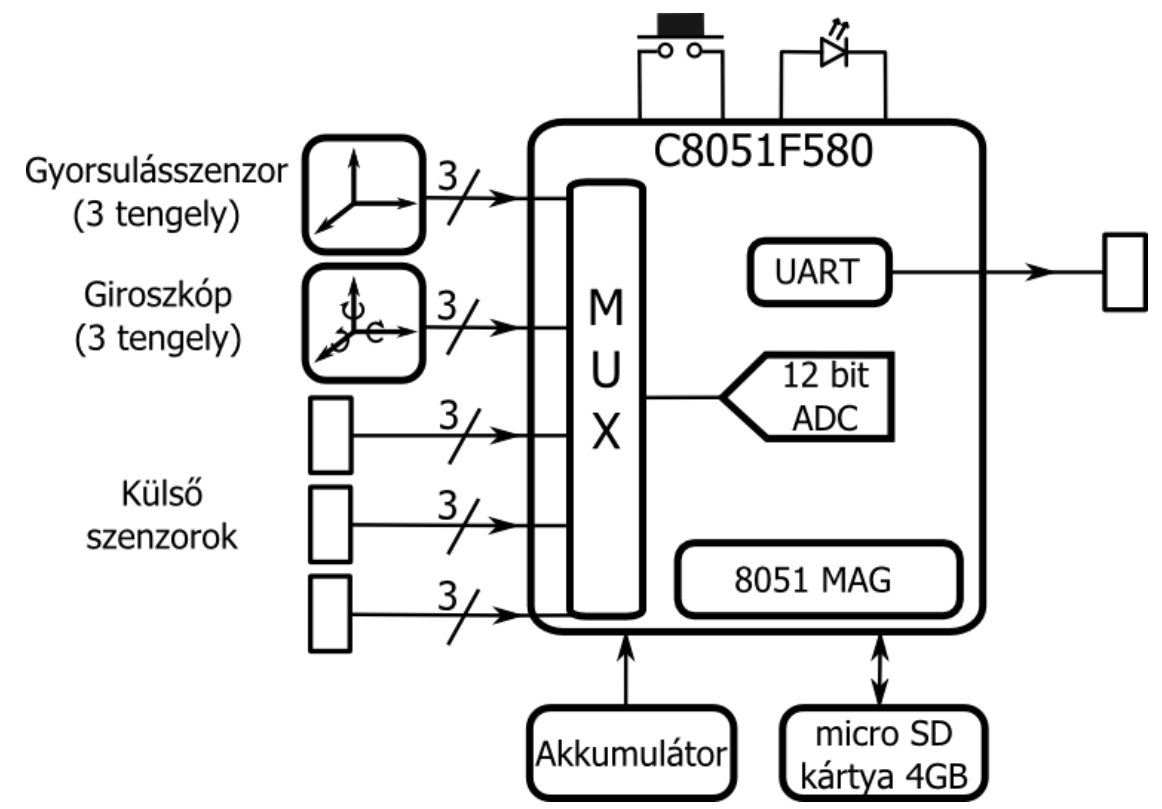

4.1. ábra: A kutatócsoport által fejlesztett „BoatDAQ” eszköz blokkvázlata.

A kajak mozgását az eszközbe integrált háromtengelyű gyorsulásszenzor és háromtengelyü giroszkóp méri. Mivel a méréseinket a kiterjedt analízist szem előtt tartva a kommercionális eszközöknél jóval magasabb - csatornánként $1000 \mathrm{~Hz}$-es mintavételi frekvenciával végeztük, az anti-aliasing és zajszűrés egyszerű, $50 \mathrm{~Hz}$-es levágási frekvenciájú elsőrendű passzív szűrőkkel történik. A mintavételi frekvencia más, a jelek analízise alapján esetlegesen a későbbiekben meghatározott optimális értékre is átállítható.

Az inerciaszenzorok (LIS352AX, LPR530AL, LPR503AL, LY503ALH [9]) alacsony zajszint és megfelelő jeltartomány alapján kerültek kiválasztásra. A háromirányú gyorsulásmérés $\pm 2 \mathrm{~g}$, a csavarási szögsebesség \pm 300 \% $\mathrm{s}$, a forgatási és billentési szögsebesség mérése pedig $\pm 30 \%$ dinamikai tartományon történik. A kalbirált szenzorok pontossága $3 \%$ alatti, amely a sok esetben relatív változások mérésén alapuló analízisünk szempontjából megfelelő. 
A műszer energiaellátását egy kisméretű, újratölthető akkumulátor biztosítja, amely egy töltő áramkörön keresztül USB 2.0 csatlakozóval kapcsolható egy számítógéphez. Az alkalmazott Li-ion 3.6 V, 1.2 Ah akkumulátor 5-8 óra aktív működést tesz lehetővé, amely egy nagyobb távú evezés vagy hosszabb edzés esetén is bőven elegendő. A mért adatok tárolása egy 4 GB-os micro SD kártyára történik, amely sok csatorna maga mintavételi rátával való mérése esetén is elegendő tárhelyet biztosít.
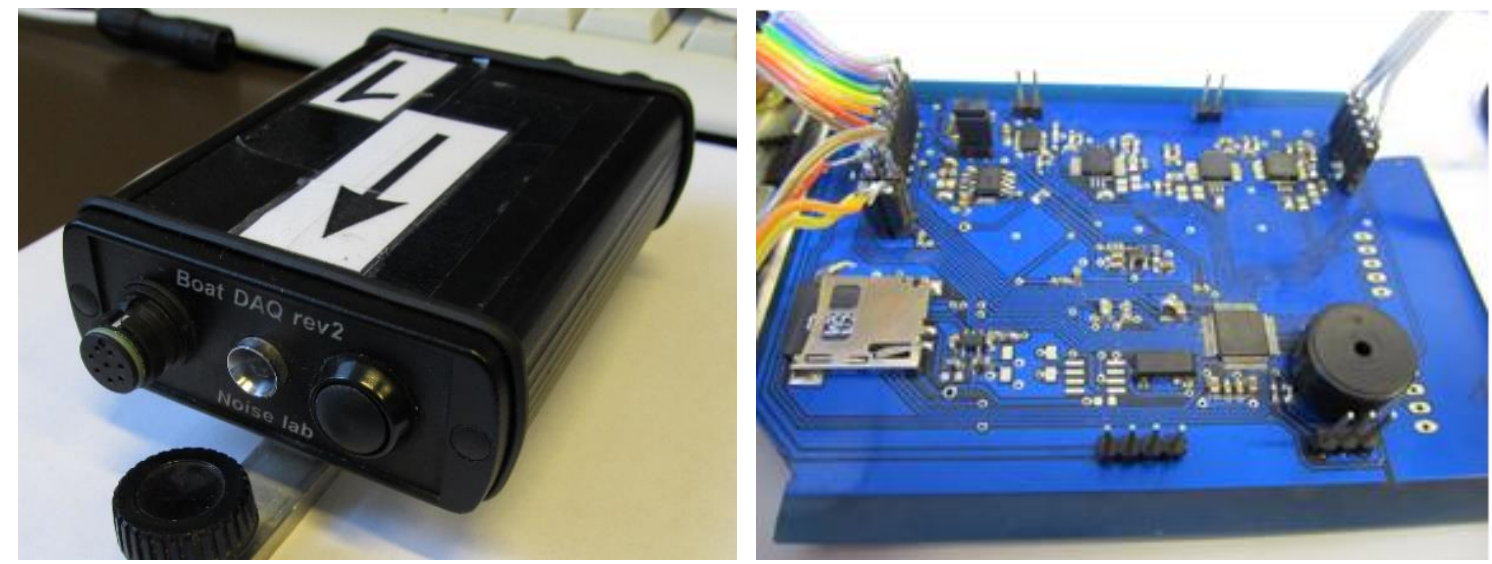

4.2. ábra: A kutatócsoport által fejlesztett „BoatDAQ” eszköz (bal oldalon) és a belsejében helyet foglaló nyomtatott áramkör (jobb oldalon)

Az eszköz egy IP65 védettségű, vízhatlan műszerdobozba került (lásd 4.2. ábra), amely a rászerelt konzollal a 4.3. ábrán látható módon, az ülés elé rögzíthető a kajakba. A mozgás hat szabadsági fokú mérését biztosító integrált szenzorokon túl további három univerzális szenzorport is található az eszközön, melyek segítségével további analóg vagy digitális kimenetű, külső szenzorok is csatlakoztathatóak, amennyiben szükséges.

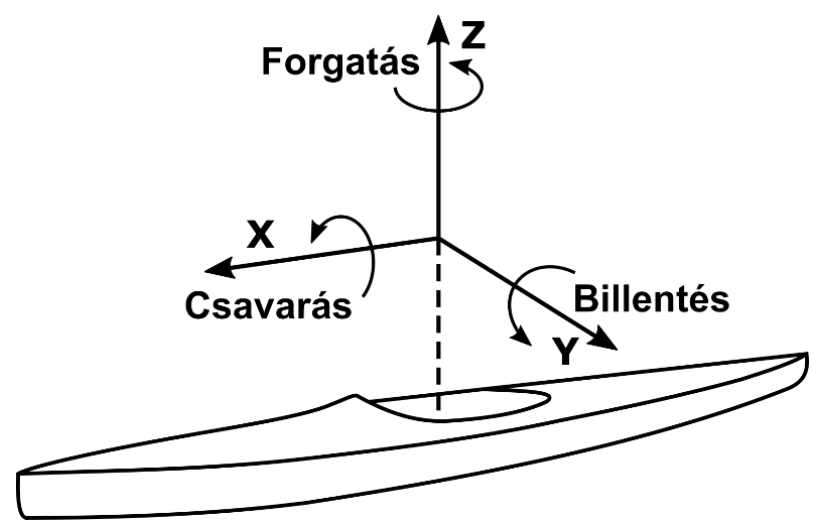

4.3. ábra: A háromirányú gyorsulás és háromirányú szögsebesség orientációi.

$\mathrm{Az}$ adatok kiolvasását a számítógéphez csatlakoztatott eszközről egy JAVA nyelven íródott szoftver végzi, mely a konfigurációs paraméterek is beállítására, továbbá a mért jelek megjelenítésésére és alapvető analízisfunkciók elvégzésére is alkalmas. 


\subsubsection{Mért mozgásjelek}

Méréseink során az eszköz a kajak és a sportoló - periodikusan változó tömegközéppontjához közel, az ülés előtt rögzítette a háromirányú gyorsulás és háromirányú szögsebesség értékeket, mely irányok a 4.3. ábrán láthatóak.

Az 1000 Hz-es mintavételi rátával rögzített hat mozgásjel néhány csapásnyi részlete a 4.4. ábrán látható. Az evezés a legtöbb sportoló esetében aszimmetrikus, azaz a jobb és bal kézzel történő húzások között valamekkora mértékű különbség figyelhető meg. Ebből következően a mozgás periódusának egy egymást követő jobb és egy bal kezes húzás együttesét tekinthetjük. Ez az észrevétel a periódusfluktuációk vizsgálata szempontjából - mind az időbeli, mind a spektrális vizsgálat során lényeges lesz számunkra.
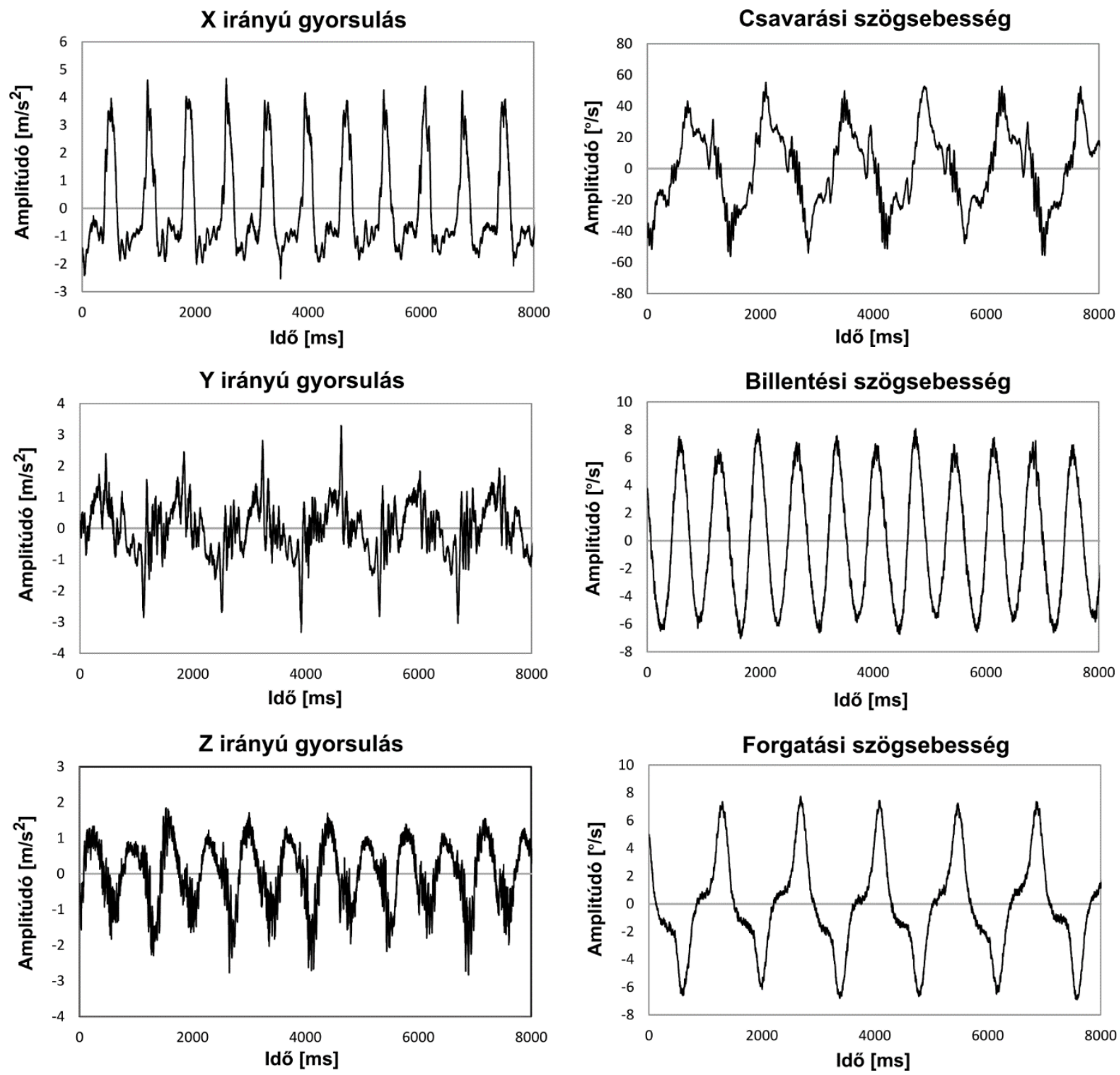

4.4. ábra: Egy tipikus evezés néhány periódusa során mért három gyorsulásjel (bal oldalon) és három giroszkóp jel (jobb oldalon). 
Ahogyan a 4.4. ábrán is megfigyelhető, három jel periódusa ( $\mathrm{az} \mathrm{x}, \operatorname{azaz}$ menetirányú gyorsulás, z irányú gyorsulás és billentési szögsebesség) látszólag egy húzáshoz tartozik, függetlenül a kivitelező kéztől, míg a másik három periódusideje (y irányú gyorsulás, csavarási és forgatási szögsebesség) a két kéz együttes húzásának ideje.

Bár a mozgás periodikus, hosszabb időintervallumot tekintve változhat; egy edzésen különböző utasítások alapján a kajakos változtathat a csapásszámon, a húzás erősségén, illetve fáradhat is. Versenyhelyzetben, vagy pályaevezés során (ahol egy táv minél rövidebb megtétele a cél) a rajt után, illetve bizonyos pontokon a sportoló megkísérli kiemelni és újra felfektetni a kajakot a víz felszínére, továbbá egy meghatározott stratégiát is követhet. Méréseink során 26 sportoló több mint 100 órányi különböző típusú evezését rögzítettük.

\subsubsection{Evezést jellemző paraméterek meghatározása}

Ahogyan az előbbiekben is említésre került, a mért jelekből a mozgás pontos térbeli rekonstrukciója a limitált mérési pontosságból kifolyólag nem lehetséges, így a mozgásjelek periódusainak detektálásával és a jelalakok vizsgálatával szerezhetünk információt a sportoló evezéséről. Értelemszerűen az analízis a menetirányú (esetünkben x irányú) gyorsulásjelen alapul, ugyanakkor az ettől eltérő irányú elmozdulások is fontosak lehetnek az evezési technika pontos elemzése során, továbbá mértékük önmagában is jelezheti a kajak optimálistól eltérő mozgását, azaz az evezésben történő hibát. Ezen irányokban azonban a gyorsulás mérése jóval érzékenyebb a különféle mechanikai hatásokra és a kajak elfordulásaira, ebből kifolyólag, ahogyan a 4.4. ábrán is látható, a mért jelek esetünkben is igen zajosnak mutatkoztak. A három szögsebességjel ugyanakkor - a kajak szögelfordulásának deriváltjaként - jóval kevésbé terhelt ilyen jellegű zajjal, így a mozgás periódusainak detektálásában és a menetirányú gyorsulásjel interpretációjában is igen hasznosnak bizonyult, a következőben bemutatott új, frekvenciatartománybeli vizsgálataink során pedig e jelek voltak a legalkalmasabbak az evezési technika értékelésére.

A kajakozás ütemét adó evezés egy periódusa a lapát helyzetét tekintve két fő részből, a víz alatti szakaszból és a légmunkából áll. A menetirányú gyorsulásjel interpretációjához végzett videóelemzésünk alapján a lapát még valamivel a jel egy periódusának pozitív szakasza előtt a vízbe kerül ("vízfogás"), és a pozitív szakasz után hagyja el a víztükröt ("szabadítás"), azonban a két nullmetszet közötti szakaszt tekinthetjük az evezés ténylegesen gyorsító hatású, effektív részének, melyet a továbbiakban "húzásnak" nevezünk [9].

Ahogyan a 4.5. ábrán is látható, egy evezés periódusideje a húzási idő és a húzások közötti idő összege. A periódusidő alapján meghatározható a csapásszám, azaz az adott periódusidővel egy perc alatt történő evezések száma, mely a kajak- 
kenu sportban használatos legfontosabb általános paraméter. A gyorsulásgörbe húzáshoz tartozó részének numerikus integrálásával megkapjuk az evezési impulzust, amely sebesség dimenziójú mennyiség megadja az adott húzással elért sebességnövekedést. Ezt a sportoló és a kajak tömegének összegével megszorozva megkaphatjuk tényleges, mechanikai értelemben vett impulzust, azonban a paraméterek statisztikai elemzése alapján ez nem szolgáltatott többletinformációt a sportolók teljesítményéről.

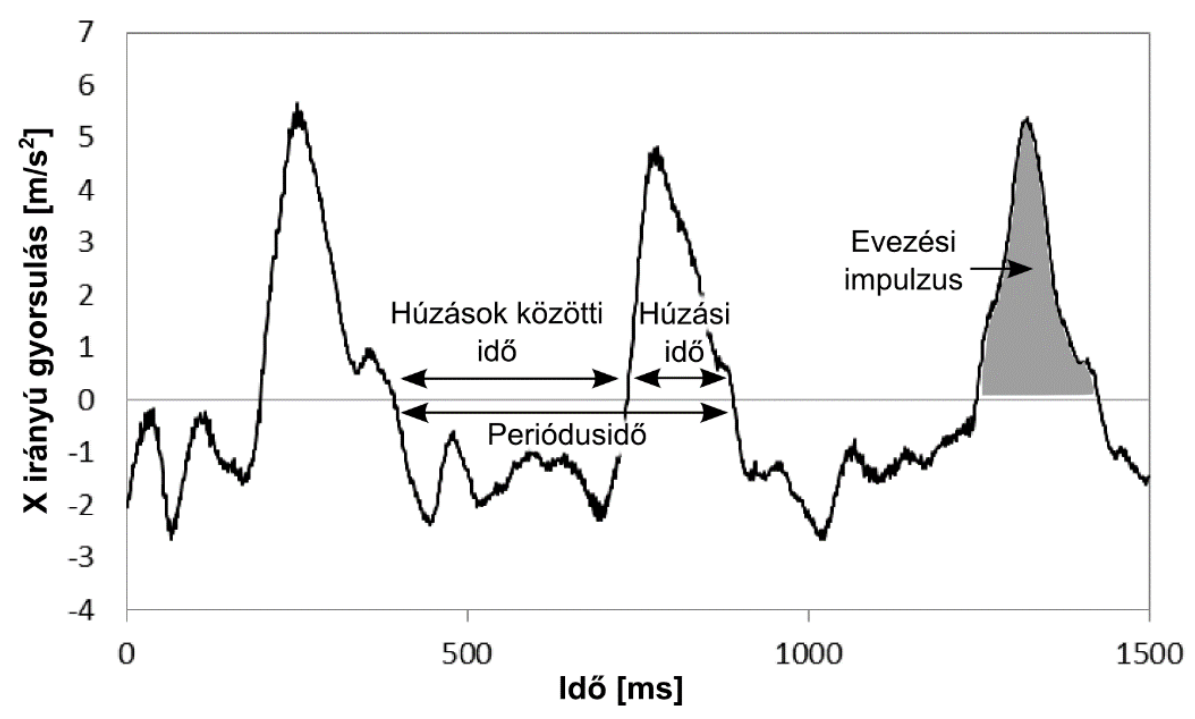

4.5. ábra: A menetirányú gyorsulásjel periódusait jellemző általános paraméterek.

Ezen alapvető mennyiségek alapján meghatározhatóak további, a teljesítmény értékeléséhez hasznos mérőszámok, mint például az összimpulzus/perc vagy a jobb és bal kezes húzáshoz tartozó evezési impulzusok aránya, a szimmetria faktor. Ez utóbbi megállapításához ismernünk kell, melyik kézzel történt az adott húzás, melyben a forgatási szögsebességjel nyújt segítséget. Az evezés szimmetrikussága minden sportoló esetében egyedi, professzionális sportolók esetében is megfigyelhető akár több mint 10\%-os eltérés a két kézhez tartozó húzás evezési impulzusa között. Ez alapján, illetve ahogy a 4.4. ábrán három mozgásjel kapcsán is megfigyelhettük, a mozgás periódusának egy jobb és egy bal kézzel történő evezést együttesen kell tekintenünk. Ennek megfelelően, a 4.6. ábrán látható módon, azaz két, egymást követő húzást jellemző paraméterek összegeként definiáljuk a kétkezes periódusidôt és kétkezes evezési impulzust.

Az evezési periódus részeit jellemző időintervallumok ilyen módú definiálása nehézkes lenne, azonban vizsgálataink során ez nem is volt szükséges, hiszen a periódusidő változásakor - például a csapásszám növelésekor - csak a húzások közötti idő mértéke változik jelentősebben, a húzás ideje megközelítőleg azonos marad, így a periódusfluktuációk további elemzéséhez a periódusidő elegendő információt hordoz magában. 


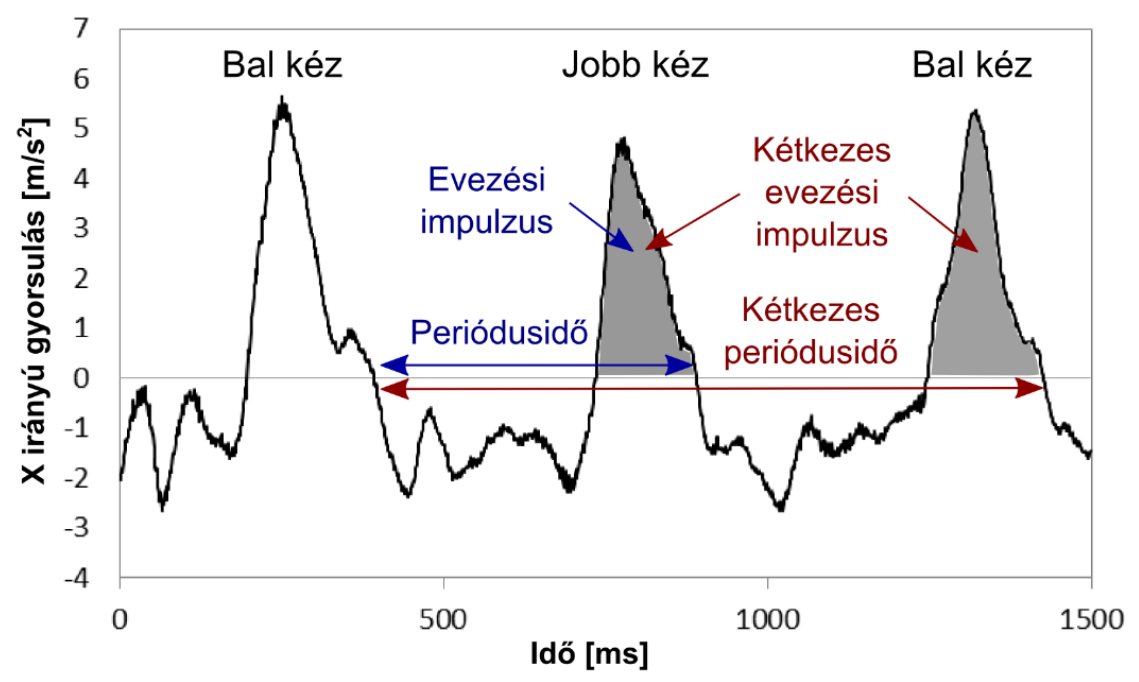

4.6. ábra: A mozgás teljes periódusát, azaz az egymást követő jobb- és balkezes húzás együttesét jellemző paraméterek.

A 4.5. és 4.6. ábrán definiált paraméterek meghatározásához az x irányú gyorsulásjel periódusainak detektálása szükséges. Ehhez elsőként a nullszintet kell meghatároznunk, melyet a teljes, egész számú periódusból álló jelszakasz átlagértéke jelentette. Ezután lehetséges a csúcsok vagy nullmetszések meghatározása, mely számos jel esetében igen nehéz feladat; egy kezdő sportoló vagy akár, ahogy a 4.7. ábrán is látható, egy professzionális, de technikai hibával evező versenyző esetében is éles, negatív tartományba történő leugrások figyelhetőek meg húzás közben és hasonló, pozitív gyorsulástartományba történő felugrások is jelentkezhetnek a légmunka során. Továbbá a jel komplexitása erősen függ a körülményektől is; egy sprintverseny során még a legszebb technikával rendelkező sportolók mozgásjelei esetében is nehezen behatárolható, hol kezdődhet egy húzás [9].

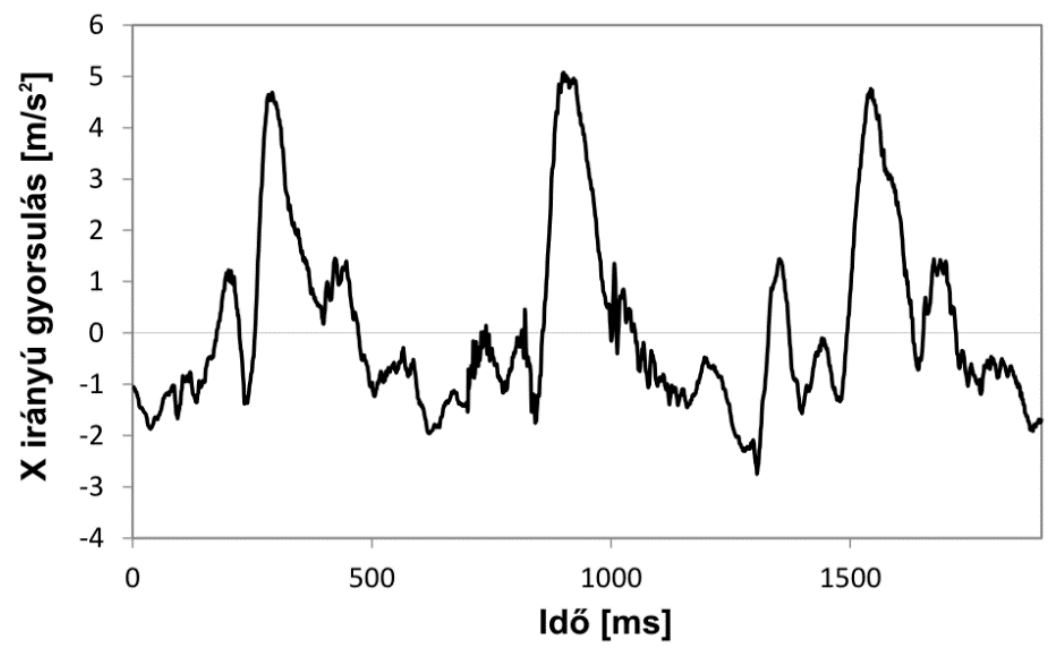

4.7. ábra: A menetirányú gyorsulásjel egy technikai hibával evező sportoló esetén. 
Mivel az evezési periódust és annak részeit a nullszint-metszések szerint definiáltuk, meghatározásukhoz egy szintmetszés-detektáláson alapuló eljárást fejlesztettem. Az említett fel- és leugrások számos téves húzás-detektálást eredményezhetnek, melynek kezelésére a nagyszámú jelek vizsgálata során felállított feltételeket és egy időbeli küszöbszintet vezettem be [89]. Bár a végső algoritmus a sprintversenyek során mért jelek esetén is megbízhatóan működött, a detektálás során felmerülő problémák is előrevetítik, hogy a meghatározott periódusidők és azok ingadozásának statisztikai vizsgálatánál kulcsfontosságú kérdés azok pontossága.
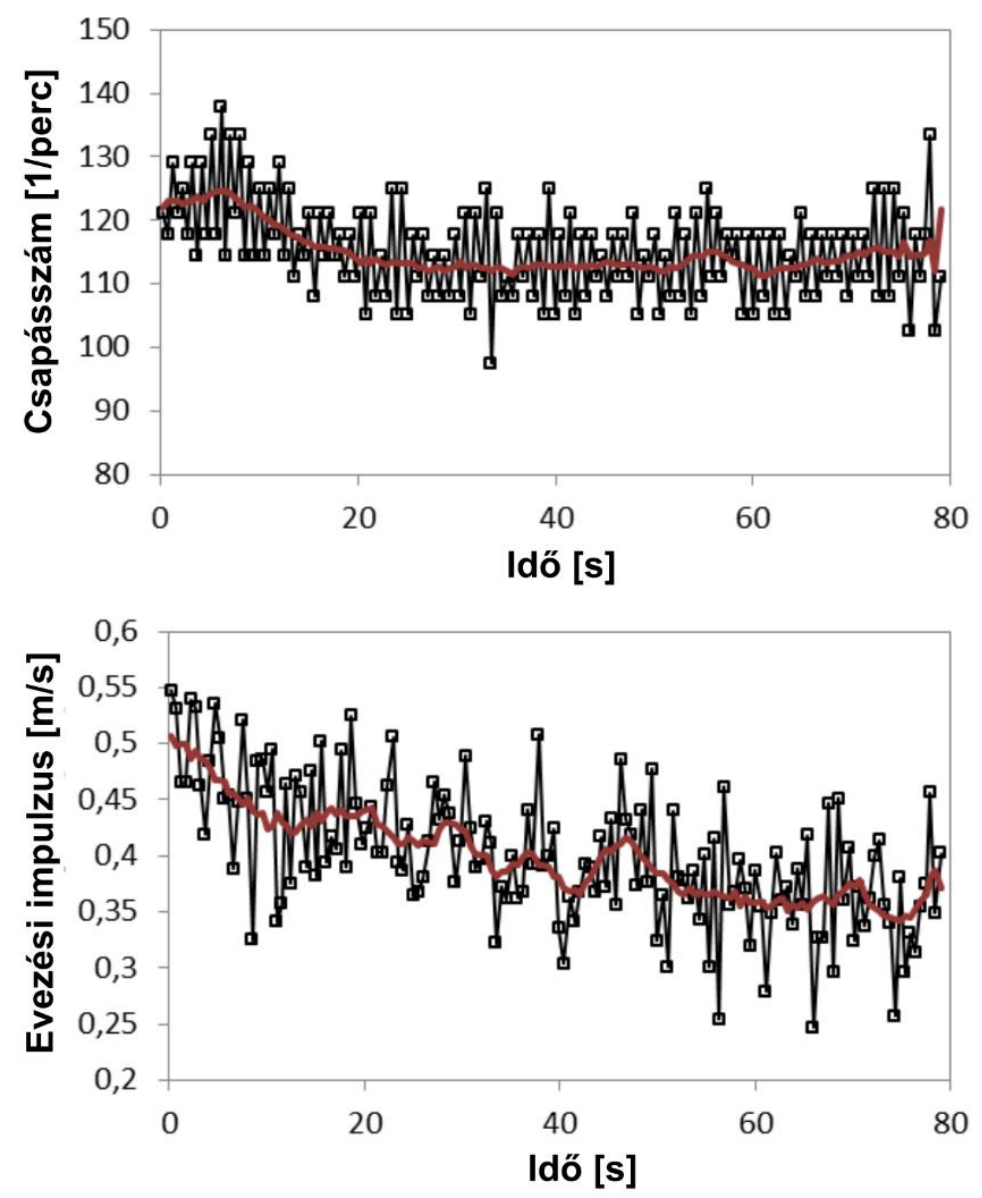

4.8. ábra: Egy sportoló egy 500 méteres versenyen történő evezésének tranziensektől mentes részére számított csapásszám (fent) és evezési impulzus (lent) trendgörbéje. Pirossal a 10-es mozgóátlaggal simított görbe látható.

A meghatározott klasszikus paraméterek ezután a teljes adatsoron is vizsgálhatóvá válnak, trendgörbén való megjelenítésük pedig igen informatív lehet az edzők és sportolók számára. A 4.8. ábrán látható, hogy egy 500 méteres verseny tranziensektől (rajttól és sprinttől) mentes részén a sportoló, bár igyekezett a csapásszámot állandó értéken tartani, ezt egyre kisebb evezési impulzus kivitelezése mellett tudta csak megvalósítani. 


\subsection{A mozgásjelek fluktuációanalízise}

A klasszikus paraméterek statiszikai elemzésével lehetőség nyílik a versenyzők különböző körülmények közötti evezésének, illetve a különböző korú és technikai képzettésű versenyzők összehasonlítására és ezzel a teljesítményüket jelző új indikátorok keresésére is. A következőkben tárgyalt fluktuációanalízis alkalmazásának ötlete azon az evezések statiszikai vizsgálata során tett megfigyelésemen alapszik, hogy az evezési periódust jellemző mennyiségek ingadozásának mértéke kapcsolatban áll a sportolók életkorával. Ennek részletes értékelése a 4.2.1. fejezetben kerül bemutatásra.
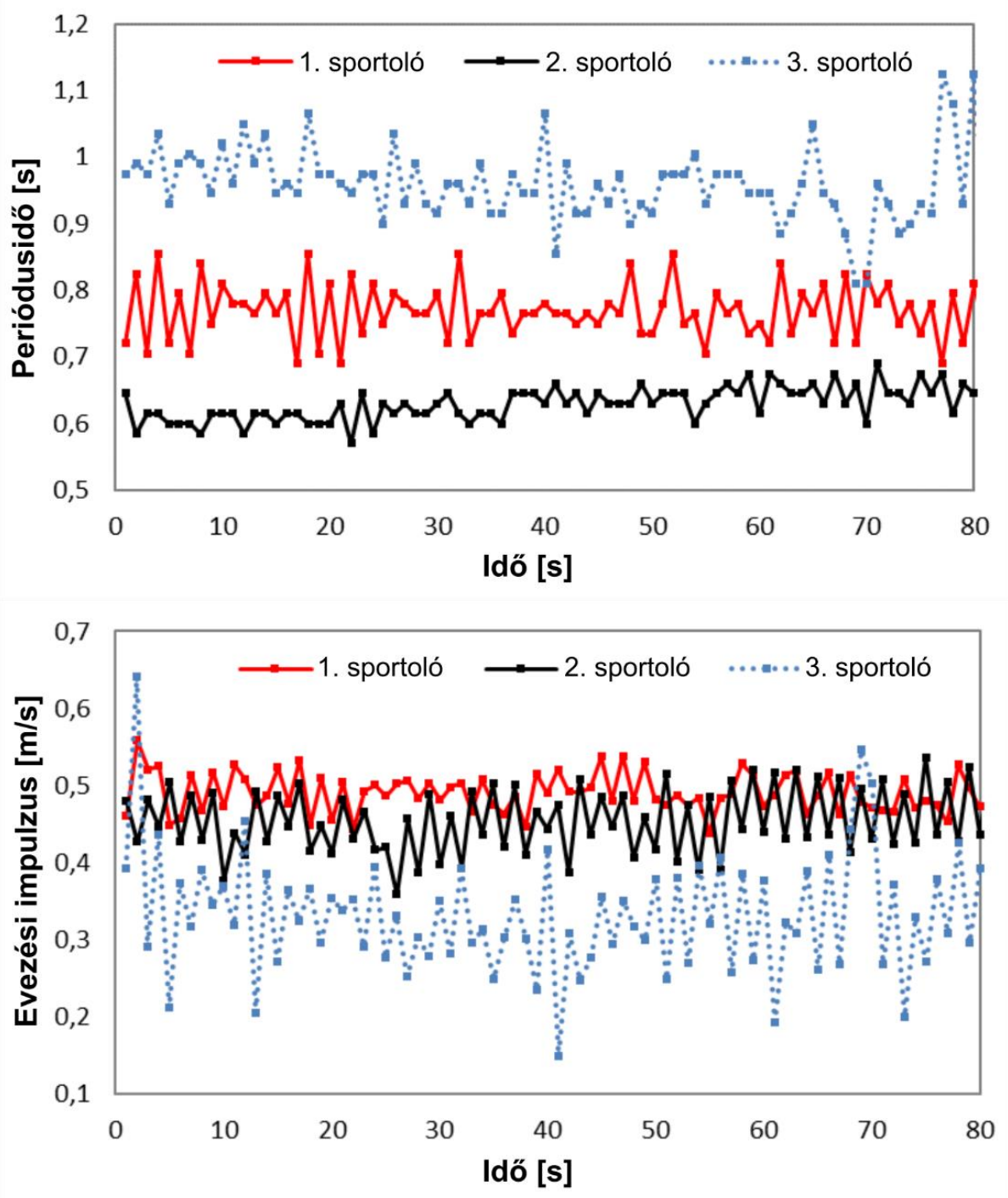

4.9. ábra: Három sportoló edzésen történő evezésének 80 másodperces szakaszára számított periódusidők (fent) és evezési impulzusok (lent) ingadozása.

A megfigyelést jól demonstrálja a 4.9. ábra, ahol három versenyző edzésen rögzített evezésének 80 másodperce esetén megállapított periódusidők és evezési impulzusok alakulása látható. Az 1. sportoló szimmetrikus evezési stílusú professzionális, világbajnok versenyző, a 2. sportoló aszimmetrikus stílusú 
professzionális versenyző, míg a 3. sportoló egy serdülő, technikailag kevésbé képzett kajakos ugyancsak aszimmetrikus stílussal. A 3. sportoló átlagos evezési impulzusa jelentősen alacsonyabb felnőtt társaiénál, amely a fizikai adottságokat figyelembe véve nem meglepő, azonban jól látható, hogy az egymást követő húzásaihoz tartozó értékek jóval intenzívebben ingadoznak, mint a másik két sportoló esetében. A periódusidők trendgörbéi alapján jól látható, hogy az átlagos csapásszám egy egyéni stílusra (és az adott körülményekre) jellemző paraméter, az e körül való ingadozás azonban ugyancsak a 3. sportoló esetében a legnagyobb.

$\mathrm{Az}$ előbbi megállapításokat látványosan illusztrálhatjuk a mennyiségek Poincaré-grafikonon való ábrázolásával. A Poincaré-grafikon, melyen egy mennyiség diszkrét idősorának egy elemét az azt megelőző elem függvényében ábrázoljuk, igen elterjedt és szemléletes eszköze az - általában periodikus jeleket jellemző mennyiségek ingadozásainak vizsgálata során, a szívritmus variabilitás esetében bevett orvosdiagnosztikai eszköz $[118,119]$.
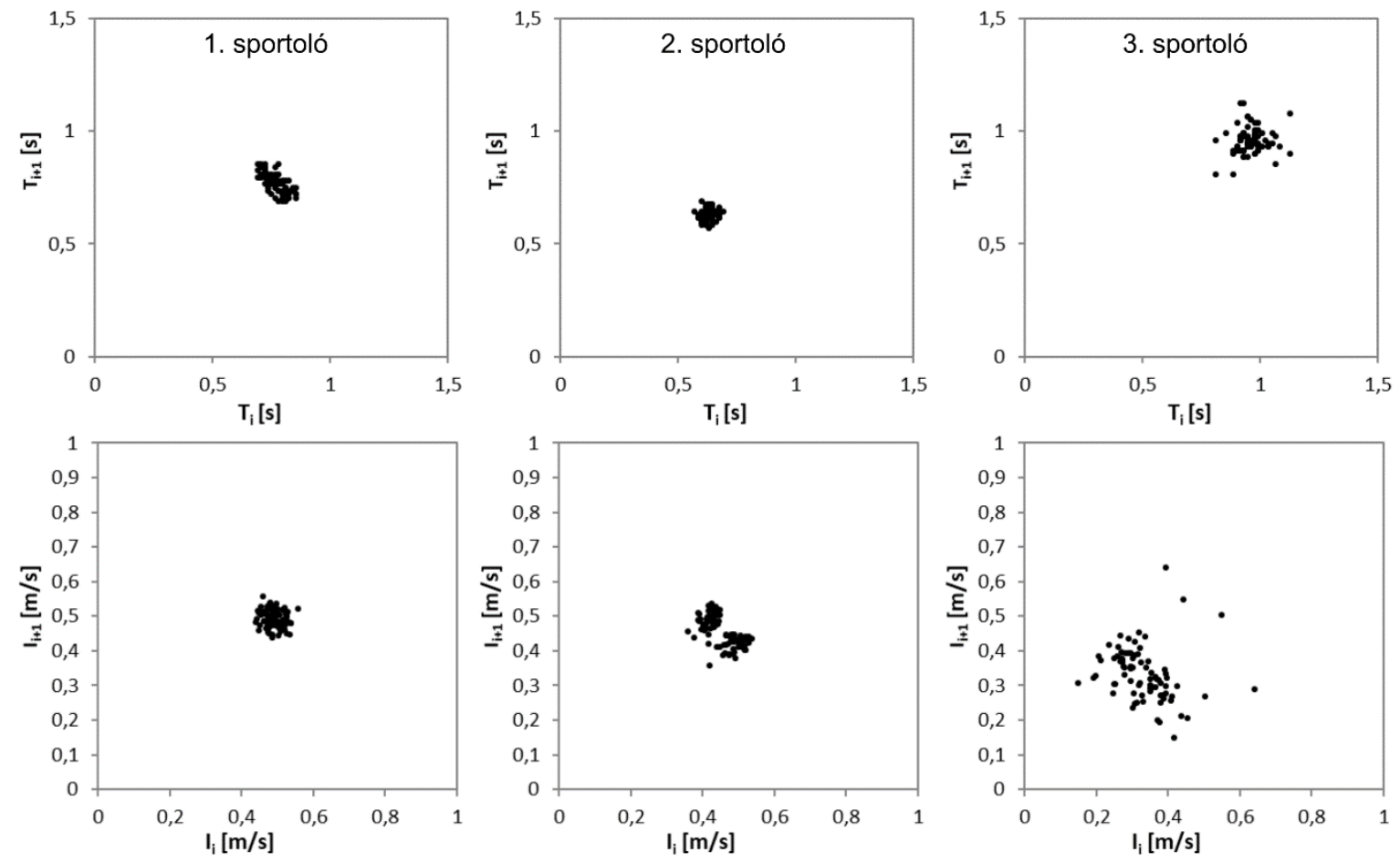

4.10. ábra: Három sportoló edzésen történő evezéseire számított, a 4.8. ábrán trendgörbén ábrázolt periódusidők (fent) és evezési impulzusok (lent) Poincarégrafikonja.

Ahogyan 4.10. ábrán látható, a serdülő sportoló esetében a pontok jelentősen nagyobb mértékben szóródnak, mint professzionális társaiénál. Megfigyelhető továbbá, hogy a 2. sportoló evezési impulzus értékei két csoportba oszthatóak, melyek a bal és jobb kézzel történő evezésnek felelnek meg, azaz a grafikon az evezés aszimmetriáját is jellemzi. A grafikonokhoz a geometriájukat leíró mérőszámok is 
rendelhetőek, melyek összefüggnek az időtartománybeli mérőszámokkal [118], így a további analízisben csak az utóbbiakra szorítkozunk.

A sportolók életkora alapján feltételezett technikai képzettség és a klasszikus paraméterek fluktuációi közötti kapcsolat értelmezhető a fejezet elején a kajak mozgásáról tett megállapításaink fényében, miszerint egyenletes evezés szükséges a kajak optimális előrahaladásához. Ezt az egyenletességet eddig az egyes evezési periódusokat jellemző mennyiségek variabilitásával szemléltettük, melyhez a húzások detektálása szükséges. Ennek tükrében megvizsgáltam, hogy a nyers mozgásjelekből a periódusok azonosítása nélkül is kinyerhető-e a szükséges információ, meghatározható-e a technikai képzettséggel hasonlóan kapcsolatban álló indikátor. Ez esetben nem lenne szükséges a komplex, számításigényes detektáló algoritmus használata, és eredményeinket nem befolyásolná az algoritmus megbízhatósága és pontossága. Ebben a mozgásjelek frekvenciatartománybeli analízise nyújthat segítséget.
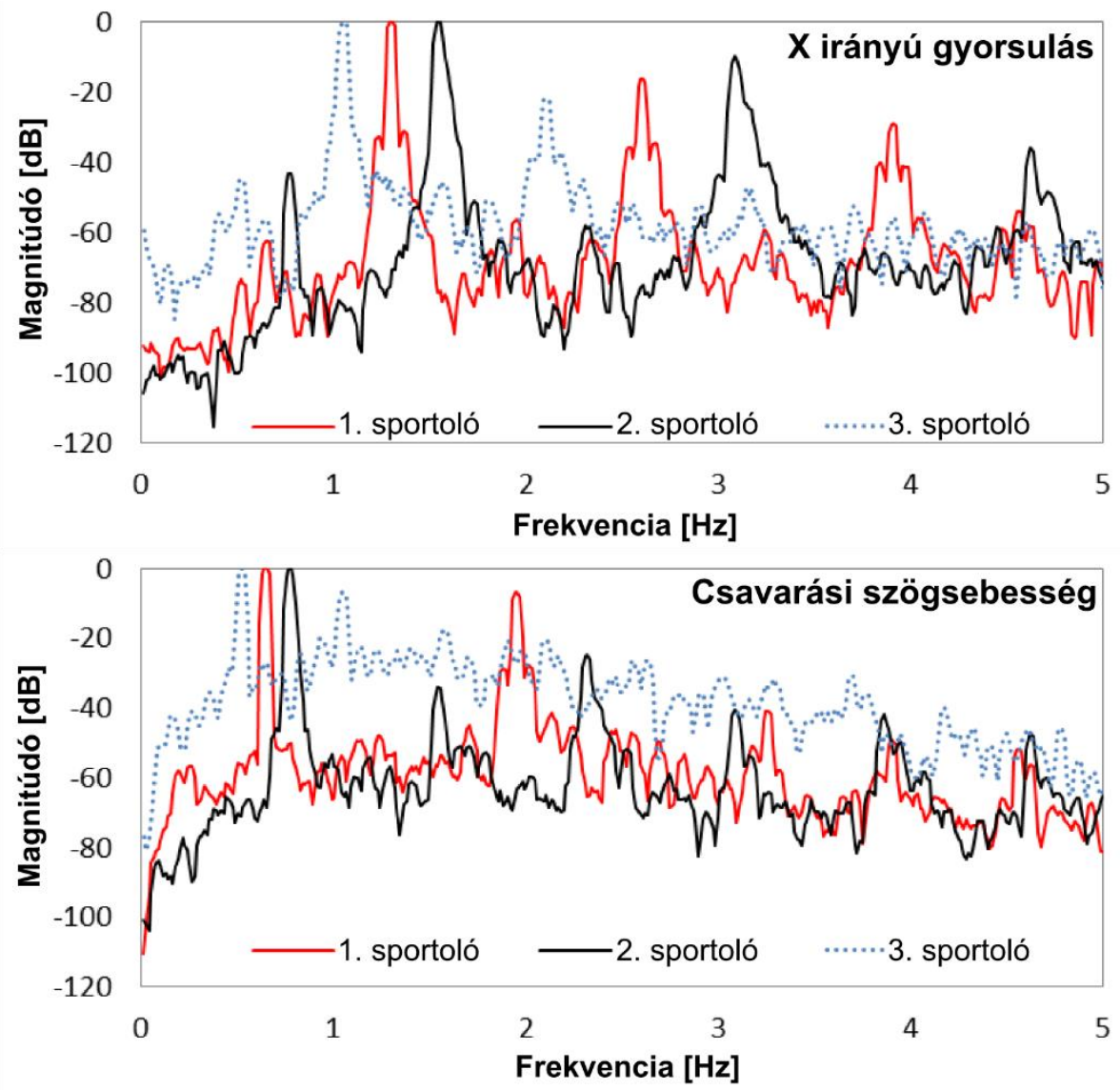

4.11. ábra: A 4.9. és 4.10. ábrán vizsgált evezések esetén mért x irányú gyorsulás (fent) és csavarási szögsebesség (lent) teljesítménysűrűség-spektruma. A spektrumok kiszámítása Hanning-ablakkal történt, továbbá azok 10-es mozgóátlaggal simítva és a domináns frekvenciához normálva kerültek ábrázolásra.

A 4.11. ábrán a három sportoló korábbiakban is vizsgált mozgása során rögzített x irányú gyorsulás és csavarási szögsebesség teljesítménysűrűség-spektruma látható. 
A spektrumok kiszámítása Hanning-ablak használatával történt, továbbá azok 10-es mozgóátlaggal simítva és a domináns frekvenciához normálva kerültek ábrázolásra. Ez utóbbi a 4.4. ábránál leírtaknak megfelelően a csavarási szögsebesség esetében a két kéz együttes húzásához tartozó frekvencia (alapharmonikus), míg a menetirányú gyorsulás esetén az egykezes periódusidő által meghatározott frekvencia (első felharmonikus). Jól látható, hogy két professzionális sportoló esetében a mozgás periódusa által meghatározott harmonikusoknál a spektrum csúcsai jóval nagyobb mértékben emelkednek ki a többi frekvenciakomponenshez tartozó értékek közül, mint a 3. sportolóhoz tartozó spektrum esetén. Másképpen fogalmaza a relatív „zajszint” e sportoló esetében jóval nagyobb.

Mint a fentebbi példákon láthattuk, a mozgásjelek fluktuációi mind idő-, mind frekvenciatartományban kapcsolatba hozhatóak a versenyzők által kivitelezett evezés technikai minőségével. E kapcsolat igazolásához és részletesebb vizsgálatához a fluktuációk mérőszámmal való jellemzése, illetve nagyszámú sportoló esetén történő statisztikai analízise szükséges. A következőkben e vizsgálatot mutatom be, a fluktuációt jellemző időtartománybeli és spektrális mérőszámok bevezetésével, illetve az azok meghatározásához szükséges különböző numerikus eljárások ismertetésével és összevetésével.

\subsubsection{A vizsgálat során használt adatsorok és osztályozásuk}

Ahogyan számos különféle típusú evezést is végezhet egy sportoló (például különböző feladatokat hajt végre edzésen vagy különböző távokon versenyez), különböző céllal is vizsgálhatjuk a mért adatsorokat, mint például az evezési technika optimalizálása, hiba detektálása, az általános paraméterek hosszabb idő alatt történő változásának vizsgálata vagy versenyen történő evezések összehasonlítása. Fő célunk a kajakos teljesítményének általános jellemzése volt az evezési technika minőségének meghatározásával, amely számos esetben segítheti az edzők és sportolók munkáját.

Egy sportoló teljesítménye és a technikai kivitelezés minősége is változhat az aktuális fizikai és mentális állapot hatására, továbbá a különböző körülmények akár egy evezés közben is megváltoztathatják azt, ezekről pedig nem rendelkezünk információval. Egy versenyző különböző evezései összehasonlíthatóak lehetnek egy verseny vagy pályaevezés időeredménye szerint, hiszen az jellemzi az aktuális teljesítményt. Ez esetben azonban a technika megvalósításának minősége mellett számos egyéb tényező is erősen befolyásolja az eredményt, továbbá szisztematikus tervezést igényel és számos verseny mérése szükséges az analízis elvégzéséhez.

A következőekben bemutatott analízis során különböző sportolók evezéseit hasonlítottam össze, melyben az előbbiek alapján nehézséget okozott, hogy azok különböző időben és körülmények között történtek. Az előbbi problémákat szem előtt tartva a nagyszámú mért jelből 14 sportoló evezése volt alkalmas az 
összehasonlításra. Olyan edzésen történő evezéseket vetettem össze, ahol a sportoló feladata egy hosszabb táv (minden esetben több mint $5 \mathrm{~km}$ ) leevezése volt. Ezen evezések első 10 percét vizsgáltam, feltételezve, hogy a sportolók számukra általános teljesítményt nyújtva egyenletesen eveznek, és még nem mutatkoznak a fáradtság jelei.

Ahogyan a 4.12. ábrán látható, mind az idő-, mind a frekvenciatartományban meghatározott indikátorok a jelek 30 másodperces időablakaira lettek kiszámítva, majd ezek 10 percre, azaz 20 ablakra vett átlagai kerültek összehasonlításra. Az időtartománybeli vizsgálat során a menetirányú gyorsulás alapján, míg a spektrális vizsgálat alkalmával mind a hat mozgásjel esetén meghatározásra kerültek a mérőszámok.
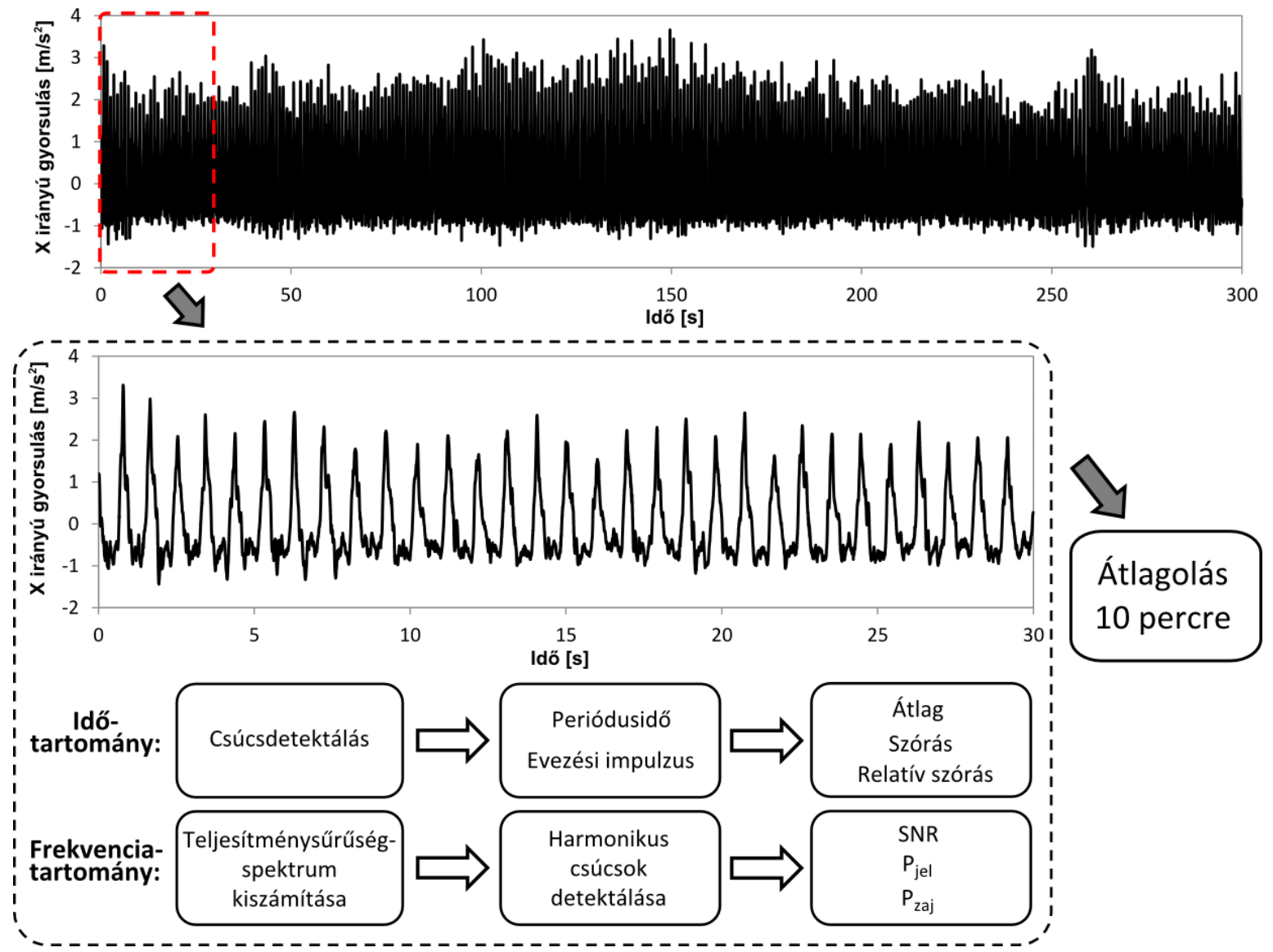

4.12. ábra: Az idő- és frekvenciatartománybeli, fluktuációanalízisen alapuló indikátorok kiszámításának módja a visgált 10 perc hosszú mozgásjeleken.

Mind az idő-, mind a frekvenciatartománybeli indikátorok értékét és pontosságát jelentősen befolyásolja az időablak méretének helyes megválasztása. Ez a vizsgált jelek esetén az evezésben történő trendszerű változások sebességét figyelembevéve fél perces értéknél mutatkozott optimálisnak.

Azzal a feltételezéssel élve, hogy a vizsgált evezéseken a sportolók átlagos teljesítménnyel és képzettségüknek megfelelő technikai kivitelezéssel eveztek, a mérőszámokat a technikai képzettség függvényében vizsgáltam. E technikai 
képzettség kvantitatív leírásához használhatjuk a sportolók életkorát, hiszen, ahogy eddigi példáinkban is láttuk, a serdülő és felnőtt versenyzők között magától értetődő a képzettség- és teljesítménybeli különbség, azonban a kapcsolat semmiképp sem egyértelmű, és kisebb korkülönbség esetén megtévesztő lehet. Ezért az életkor mellett a közreműködő edző által felállított, a technikai szint 1-től -10-ig terjedő osztályozásának függvényében is vizsgáltam a fluktuációanalízissel megállapított mérőszámokat.

\subsubsection{Időtartománybeli indikátorok}

Az időtartománybeli vizsgálat alapját az adja, hogy a kajak mozgásának egy periódusát jellemző mennyiségek variabilitása, azaz az evezés egyenletessége szorosan összefügg a megfelelő mozdulatsor kivitelezésének minőségével. Ez a kapcsolat megfigyelhető a 4.13. ábrán, ahol a kétkezes periódusra számolt periódusidő és evezési impulzus relatív szórása a sportolók életkorának és technikai szintjének függvényében ábrázolva egyértelmű, trendszerű csökkenést mutat (a szórás kiszámításának módja az alábbiakban kerül tárgyalásra). A grafikonokon minden pont egy sportoló evezésének felel meg, melyre az indikátor a 4.12. ábrán bemutatottaknak megfelelően, egy hosszútávú evezés első 10 percének 30 másodperces, egymást követő időablakaira meghatározott értékek átlagaként került kiszámításra.
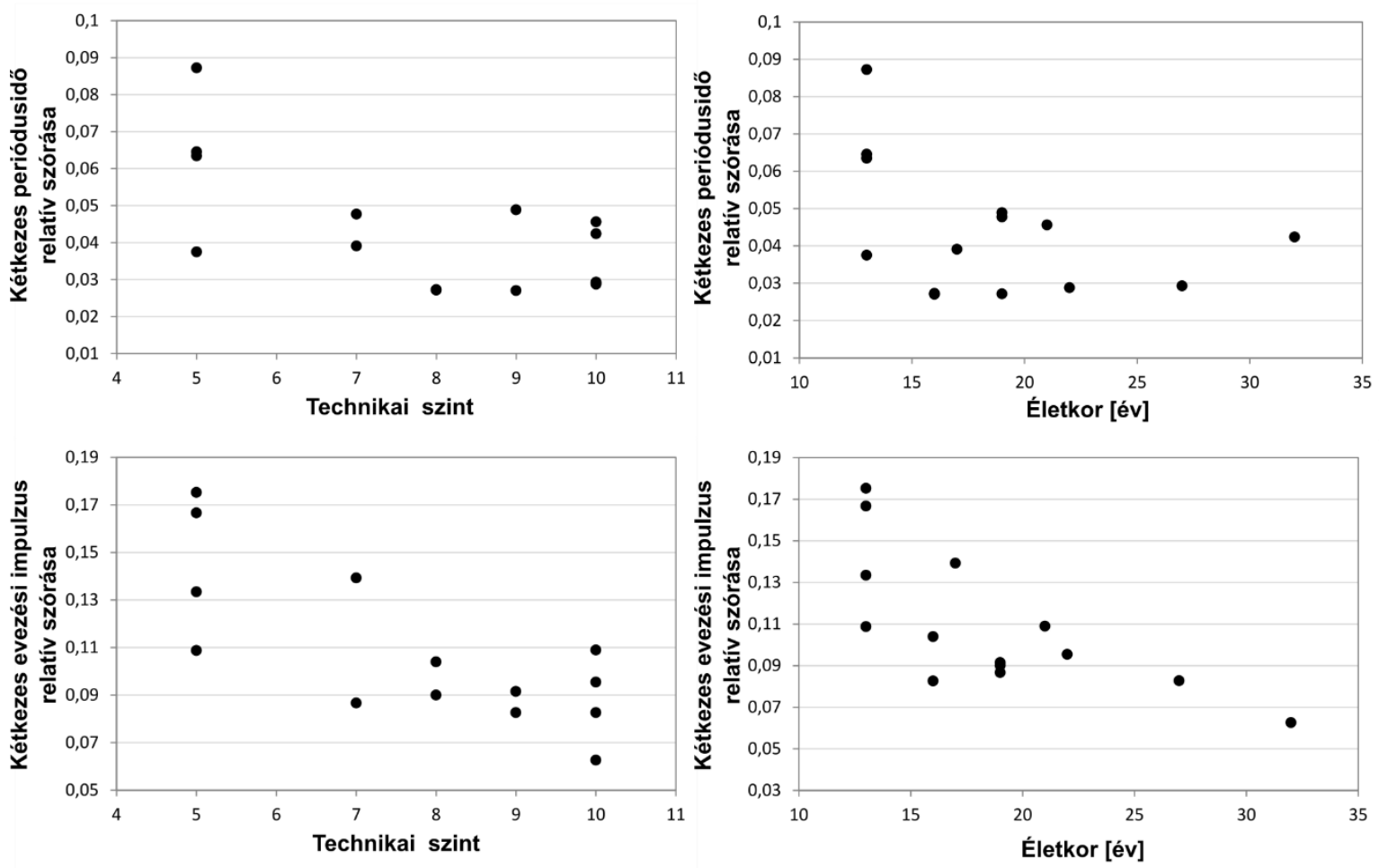

4.13. ábra: A kétkezes periódusidő (fent) és kétkezes evezési impulzus (lent) relatív szórása a technikai szint edzői osztályozásának (bal oldalon) és a sportolók életkorának (jobb oldalon) függvényében. 
Bár, a 4.2.1. fejezetben említett okoknak megfelelően a sportolók életkora és az edzői osztályozás sem határozza meg egyértelműen a vizsgált evezések minőségét, annak kapcsolata mind az evezési impulzus, mind a periódusidő variabilitásával egyértelműen megfigyelhető. Ugyanakkor a variabilitás meghatározása során számos kérdés felmerül; egy- vagy kétkezes periódusra számított mennyiségek szórását számítsuk-e ki, normáljuk-e azt a mennyiségek átlagával, továbbá a mennyiségek trendszerű változása befolyásolja-e ezen értékeket?

E kérdések megválaszolásához összevetetettem a különböző módokon számolt indikátorokat a szórások és a technikai szintek korrelációját jellemző, a 2.1.2. fejezetben definiált determinációs együttható $\left(R^{2}\right)$ segítségével. Az együttható használata lineáris kapcsolatot feltételez a technikai szint és a vizsgált indikátorok között, melyet a vizsgált minta méretéből kifolyólag egyértelműen nem áll módunkban igazolni, azonban a 4.13. ábrán megfigyelhető trend alapján megfelelő hipotézisnek mutatkozik és lehetőséget ad a módszerek összehasonlítására. A képzettség életkorral való lineáris kapcsolata az előzőekben említetteknek megfelelően könnyen megkérdőjelezhető, a továbbiakban így az osztályozás alapján történő vizsgálatra szorítkozunk.

A 4.14. ábrán látható az evezési impulzusra és periódusidőre meghatározott, különböző időtartománybeli indikátorok és a technikai szint kapcsolatát jellemző (a 4.13. ábrának megfelelő grafikonra illesztett egyenes segítségével kiszámított) $R^{2}$ értéke mind egy-, mind a kétkezes periódus esetén. Ahogyan leolvasható, a vizsgált mennyiségek dimenziójában értelmezett szórásértéknél az átlaggal leosztott, azaz relatív szórás az evezés minőségével erősebb kapcsolatot mutat.

$\mathrm{Az}$ általános paraméterekben történő trendszerű változás, mint például a csapásszám változtatása vagy a 4.8. ábrán látható módon a fáradás hatására az evezési impulzus csökkenése befolyásolhatja a paraméterek variabilitását jellemző indikátorok értékét. Ezt szem előtt tartva a trendet egy, az alábbi egyenletekkel meghatározott, $f_{\mathrm{c}}=0.5 \mathrm{~Hz}$ levágási frekvenciájú elsőfokú digitiális végtelen impulzusválasz szűrővel távolítottam el a mennyiségek idősorából.

$$
\begin{aligned}
& y_{i}=a_{0} x_{i}+a_{1} x_{i-1}+b y_{i-1}, \\
& a_{0}=\frac{1+e^{-2 \pi \frac{f_{\mathrm{c}}}{f_{\mathrm{s}}}}}{2}, \\
& a_{1}=-\frac{1+e^{-2 \pi \frac{f_{\mathrm{c}}}{f_{\mathrm{s}}}}}{2}, \\
& b=e^{-2 \pi \frac{f_{\mathrm{c}}}{f_{\mathrm{s}}}} .
\end{aligned}
$$


ahol $x_{i}$ a szűrendő jel (periódusidő vagy evezési impulzus), $y_{\mathrm{i}}$ pedig a szűrt jel $i$-ik pontja, $f_{\text {s }}$ pedig a mintavételi frekvencia.

Ez utóbbi - mivel éppen a vizsgált periódusfluktuációk miatt a jel nem egyenletesen mintavételezett - az átlagos periódusidő reciprokaként került meghatározásra. Természetesen ez okozhat kis mértékű eltérést a szűrt jelben, azonban ennek hatása az analízis során elhanyagolható volt. Mint a 4.14. ábrán látható, 30 másoperces időablak használata esetén az eljárásnak nincs szignifkáns szerepe, ugyanakkor hosszabb, versenyen történő evezések összehasonlítása esetén hasznos lehet az eljárás.
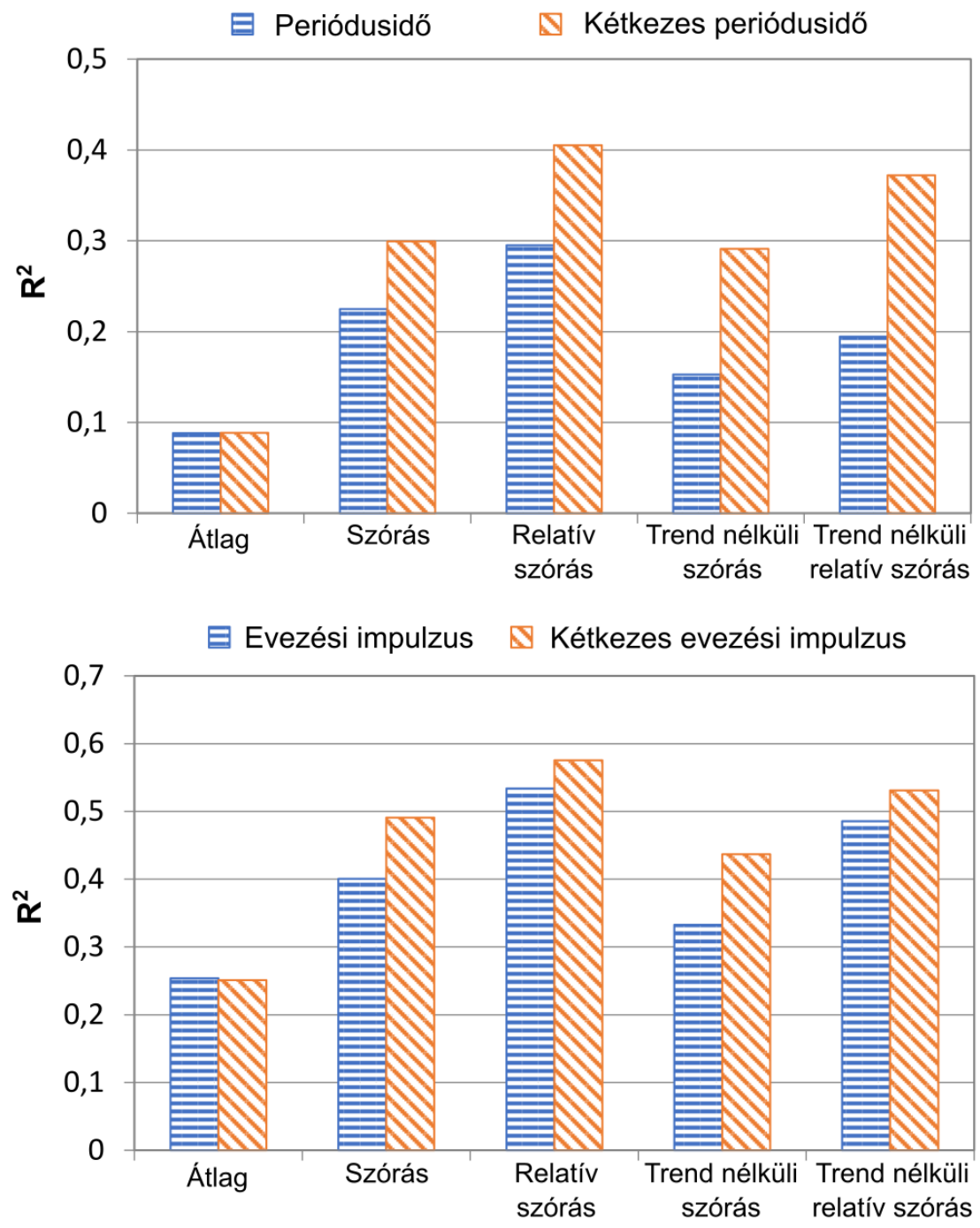

4.14. ábra: A technikai szint és a periódusidő (fent) illetve az evezési impulzus (lent) közötti kapcsolatot leíró $R^{2}$ értéke különböző módon számított időtartománybeli indikátorok esetén. Az indikátorok meghatározása a 4.11. ábrán leírt módon történt.

A fenti eljárások a kajak mozgásának periodicitásán alapulnak, az időtartománybeli vizsgálatoknál használt menetirányú gyorsulásjel esetén pedig úgy tűnhet, hogy egy periódus egy evezésnek felel meg. A 4.1.2. fejezetben azonban 
megállapítottuk, hogy a mozgás teljes periódusa egy jobb- és egy balkezes evezés együttese, melyet alátámasztanak a 4.14. ábrán összefoglalt eredmények, melyek szerint minden szórás alapú indikátor esetén a kétkezes periódust leíró mennyiségek mutatnak erősebb kapcsolatot a technikai képzettséggel.

A 4.14. ábrán látható továbbá, hogy az evezési impulzus variabilitása szorosabb kapcsolatot mutat a technikai szinttel, mint a periódusidőé, ahogyan a fejezet elején a trendgörbéken és Poincaré-grafikonokon is megfigyelhető volt. A viszonylag kis $R^{2}$ értékek oka többek között lehet a kisszámú mintára történő illesztés is, de fontos megjegyezni, hogy minden szórás alapú indikátor jelentősen nagyobb korrelációt mutatott a technikai képzettséggel, mint a mennyiségek átlaga, melyet elterjedten alkalmaznak a sportolók teljesítményének értékelésére. Természetesen az evezési impulzus átlaga elsősorban nem is a technikai megvalósítást hivatott leírni, ugyanakkor ez alapján kijelenthetjük, hogy az új indikátorok hasznos többletinformációt hordoznak a sportoló evezési technikáját illetően.

\subsubsection{Spektrális indikátorok}

Ahogyan a 4.11. ábrán láthattuk, a kezdő és professzionális sportolók evezése közötti különbség a mozgásjelek teljesítménysűrűség-spektrumában $(S(f))$ is megfigyelhető volt. A mozgás periódusa által meghatározott frekvenciaértékhez, azaz az alapharmonikushoz, illetve ennek többszöröseihez, a felharmonikusokhoz tartozó csúcsok jelentősen nagyobb mértékben „emelkedtek ki” a spektrum többi tartományához képest a felnőtt sportolók esetében. Ahogyan az eddigiekben láttuk, a fluktuációanalízis használata azon alapszik, hogy az optimális előrehaladáshoz a kajak egyenletes, periodikus mozgása szükséges. Ezen egyenletesség - ahogy az előbbi megfigyelésünk is mutatja - frekvenciatartományban is vizsgálható, hiszen a mozgás periodikus komponenseit az evezési periódus által meghatározott frekvencia szerint szeparálhatjuk a többi jelkomponenstől, továbbá ezek teljesítményének aránya is vizsgálhatóvá válik.

Fontos kiemelni, hogy a fejezetben bemutatott módszer előnye, hogy nem szükséges az evezések detektálása, mely csak összetett algoritmusokkal lehetséges, és komplex jelalakok esetén a húzások azonosításának pontossága jelentősen befolyásolhatja az indikátorok megbízhatóságát. A frekvenciatartománybeli vizsgálathoz csupán a gyorsulásszenzorokkal és giroszkópokkal mért nyers jelek teljesítménysűrűség-spektrumát kell - a 2.2.2. fejezetben bemutatott módon - azok diszkrét Fourier-transzformáltja alapján kiszámítanunk. Ezen felül, az időtartománybeli eljárásokkal ellentétben nem kell a menetirányú gyorsulásjelre szorítkoznunk, mind a hat mozgásjel esetén kiszámíthatjuk indikátorainkat.

A fentiek alapján a periódusfluktuációk frekvenciatartománybeli vizsgálatának alapját a jel periodikus komponenseinek a többi komponenshez való viszonya adja 
meg, így spektrális indikátoraink megalkotásához használjuk fel a múszaki területeken bevett jel-zaj viszonyt (signal-to-noise ratio, SNR):

$$
S N R=\frac{P_{\text {jel }}}{P_{\text {zaj }}} .
$$

E definícióban $P_{\text {jel }}$ a „hasznos jel” teljesítményét jelöli, amely alkalmazási területtől függően lehet az információt hordozó komponensnek vagy egy rendszer gerjesztési frekvencián való válaszának teljesítménye [16], míg a többi frekvenciatartományon a

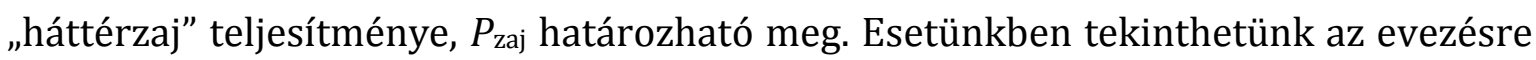
gerjesztésként, vagy más szemszögből nézve, a korábbi megállapításainknak megfelelően a periodikus mozgást tekinthetjük az evezés hasznos részének. Ezen teljesítményeket megkaphatjuk $S(f)$ megfelelő frekvenciatartományokon történő integrálásával. E frekvenciatartomány a $P_{\text {jel }}$ esetén a (4.6) egyenlet szerint az $f_{0}$ alapharmonikus és $N-1$ felharmonikus frekvencia $w / 2$ környezete, míg a $P_{\text {zaj }}$ esetén a spektrum fennmaradó része, azaz a (4.7) egyenletnek megfelelően $S(f)$ teljes tartományra vett integrálja és a $P_{\text {jel }}$ különbségeként.

$$
\begin{aligned}
& P_{\text {jel }}=\sum_{i=1}^{N} \int_{i \cdot f_{0}-\frac{w}{2}}^{i \cdot f_{0}+\frac{w}{2}} S(f) d f, \\
& P_{\text {zaj }}=P_{\text {teljes }}-P_{\text {jel }}=\int_{0}^{f_{\mathrm{s}} / 2} S(f) d f-\sum_{i=1}^{N} \int_{i \cdot f_{0}-\frac{w}{2}}^{i \cdot f_{0}+\frac{w}{2}} S(f) d f,
\end{aligned}
$$

ahol $f_{\mathrm{s}}$ a mintavételi frekvencia. Az $N$ és $w$ értékének helyes megválasztása, azaz hogy hány felharmonikust veszünk figyelembe a hasznos jel esetén, és hogy numerikusan a csúcsokat milyen szélességben integráljuk, az indikátorok meghatározásának kulcskérdése lesz a következőkben.

A periodikus komponensek teljesítménye kapcsán figyelembe vett csúcsok meghatározásánál már az alapharmonikus kijelölése sem egyértelmű; ahogy a 4.1.2. fejezetben tárgyalásra került, és a 4.10. illetve az alábbi 4.14. ábrán is látható, a mozgás periódusa látszólag kétféle lehet a különböző jelek esetében. Az x irányú gyorsulás, a z irányú gyorsulás és a billentési szögsebesség periódusa látszólag független a kivitelező kéztől, ezesetben a spektrumok domináns csúcsa az egykezes periódusidő által meghatározott frekvenciához, míg az y irányú gyorsulás, a csavarási és a forgatási szögsebesség domináns csúcsa a mozgás teljes, azaz kétkezes periódusideje által meghatározott frekvenciához tartozik. A jelek egységes kezeléséhez, tekintsük a mozgás teljes - kétkezes - periódusa által meghatározott frekvenciát az alapharmonikus, az egykezes periódushoz tartozó frekvenciát pedig az 
első felharmonikus frekvenciájának. Mivel a két kéz húzásának periódusideje is eltérhet kis mértékben, így az egykezes periódusú mozgásjelek esetén a jóval kisebb magnitúdójú alapharmonikus és az első felharmonikus aránya az evezés szimmetriáját jellemzi, továbbá a jelenség a csúcsok kiszélesedéséhez vezet.

A 4.15. ábrán látható egy-egy példa a két típusú jelre, és azok teljesítménysűrűség-spektrumára. Ahogyan megfigyelhető, a felharmonikusok aránya is és a csúcsok magnitúdójának értéke is jelentősen eltér a két esetben, ebből következően az ezekből meghatározott indikátorok értékei is nagy mértékben különbözni fognak.
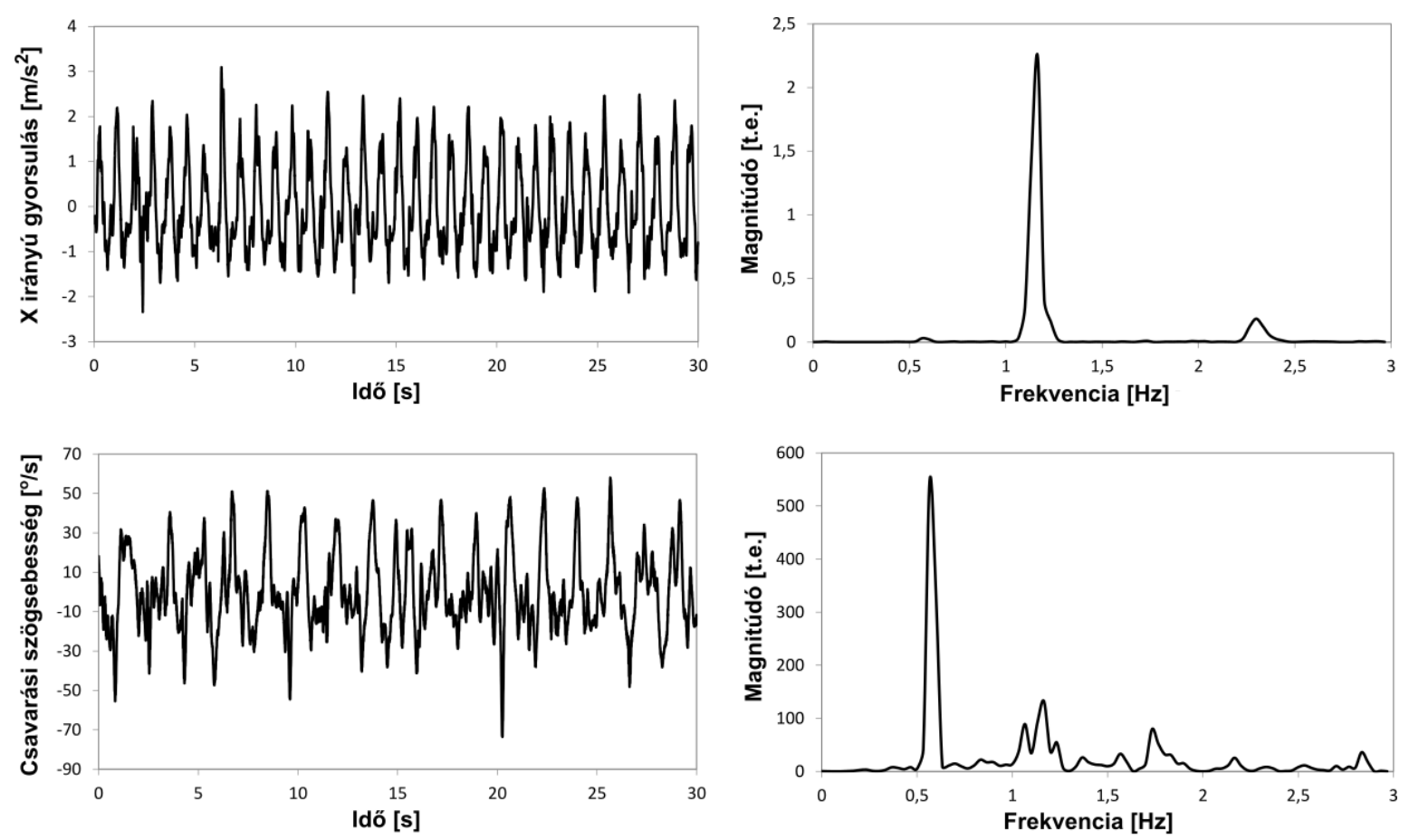

4.15. ábra: $\mathrm{Az} \mathrm{x}$ irányú gyorsulás (fent) és a csavarási szögsebesség (lent) időtartománybeli alakja (bal oldalon) és Hanning-ablakkal számított teljesítménysűrűség-spektruma (jobb oldalon). Az x irányú gyorsulásjel domináns frekvenciája az első felharmonikus (egykezes evezési periódus), míg a csavarási szögsebességé az alapharmonikus (kétkezes evezési periódus).

Ahogyan látható, annak meghatározása, hogy mely felharmonikus csúcsok emelkednek ki jelentősen, és milyen sávszélességben érdemes a teljesítményüket kiszámítani, azaz - többek között - $N$ és $w$ értékének megválasztása - korántsem magától értetődő.

Ezen kérdések részletesebb elemzése előtt tekintsük meg a hasznos jel és zaj teljesítményének, illetve ezek arányának kapcsolatát az evezés minőségével $N=6$ és $w=0,2 \quad \mathrm{~Hz}$ esetén. A 4.16. ábrán láthatjuk a csavarási szögsebességjel teljesítménysűrűség-spektruma alapján számolt $P_{\text {jel, }} P_{\text {zaj }}$ és $S N R$ értékeket a technikai szint edzői osztályozása, illetve a sportolók életkorának függvényében. Az indikátorok 
a 4.2.2. fejezetben is vizsgált adatsorokra, a 4.12. ábrán bemutatottaknak megfelelő módon, azaz egy hosszútávú evezés első 10 percének 30 másodperces ablakaira számított értékek átlagként kerültek meghatározásra.
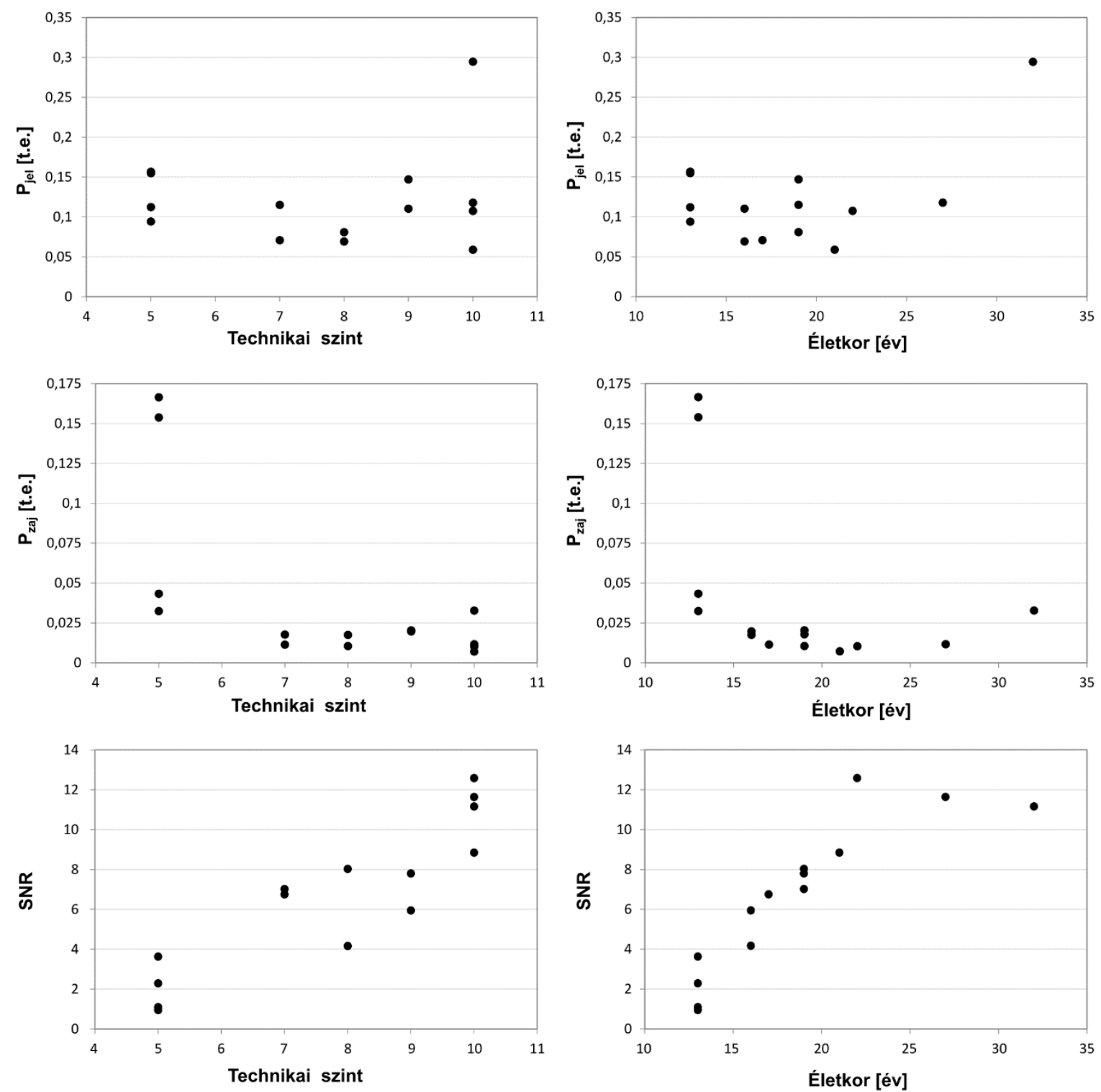

4.16. ábra: A hasznos jel ( $P_{\text {jel, }}$ fent) és a zaj teljesítménye ( $P_{\mathrm{zaj}}$, középen) illetve ezek aránya, a jel-zaj viszony ( $S N R$, lent) a technikai szint (bal oldalon) és az életkor (jobb oldalon) függvényében, a csavarási szögsebességjel esetén. A teljesítménysűrűségspektrum Hanning-ablakkal került kiszámításra, az $S N R, P_{\text {jel }}$ és $P_{\text {zaj }}$ pedig a (4.5)- (4.7) egyenletek alapján került meghatározásra, ahol $N=6$ és $w=0,2 \mathrm{~Hz}$.

Jól látható, hogy a jel-zaj viszony igen erős kapcsolatot mutat a versenyzők technikai szintjével és életkorával is. Hasonló, bár kevésbé egyértelmű kapcsolat a zajszint esetében is megfigyelhető, amely értelmezhető az alapján, hogy az az egyenletes evezéstől eltérő ütemű mozgások teljesítményével áll kapcsolatban. Ahogyan korábban megállapítottuk, különböző fizikumú versenyzők jelentősen eltérő 
evezési technikával is lehetnek hasonlóan sikeresek, így az előrehaladást elsősorban előidéző periodikus komponensek teljesítményének gyenge kapcsolata a technikai szinttel ugyancsak értelmezhető, a befektett teljesítmény abszolút értékével szemben annak a zajjal való aránya jellemzi a helyes technikai megvalósítást.

Ezen megfigyeléseinket támasztja alá a 4.17. ábra is, amelyen az időtartománybeli indikátorok vizsgálatával egyező módon, a determinációs együttható $\left(R^{2}\right)$ segítségével írjuk le a 4.15. ábrán is látható kapcsolatot a vizsgált indikátor és a technikai szint között. Egyértelműen az $S N R$ áll a legszorosabb kapcsolatban az evezés minőségével, a korreláció mértéke két jel esetében is nagyobb, mint amelyet bármely időbeli indikátornál láthattunk. A 4.17. ábrán továbbá a hat mozgásjelre számított indikátor összevetése is látható; a forgatási és csavarási szögsebességjelekre meghatározott mérőszámok mutatják a legerősebb összefüggést az evezés minőségével. E jelek esetén a domináns frekvencia az alapharmonikus frekvenciája, azaz 4.2.2. fejezetben tett megállapításunkat alátámasztva ez esetben is levonhatjuk a következtetést, miszerint a kétkezes periódusú jelek karakterizálják jobban az evezést.

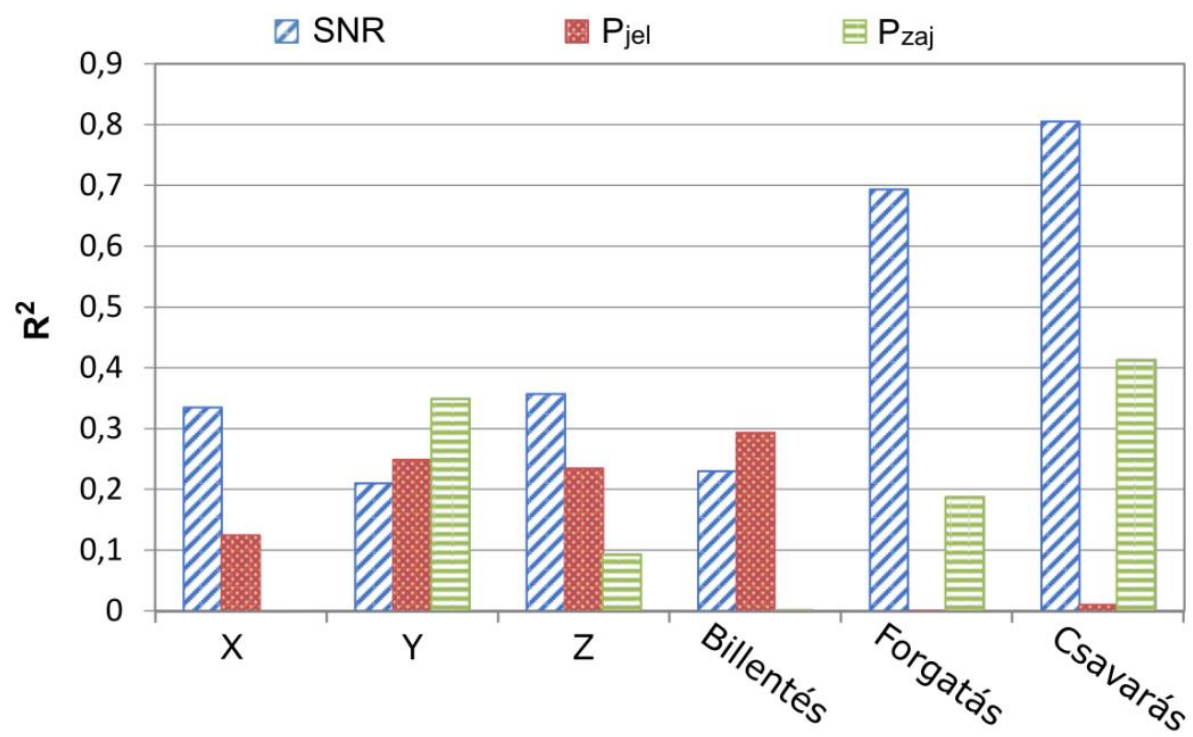

4.17. ábra: A technikai szint és a három spektrális indikátor $\left(S N R, P_{\text {jel }}\right.$ és $\left.P_{\text {zaj }}\right)$ kapcsolatát leíró $R^{2}$ a hat mozgásjel esetén. Az indikátorok értékének meghatározása során a teljesítménysűrűség-spektrum Hanning-ablakkal, az $S N R, P_{\text {jel }}$ és $P_{\text {zaj }}$ pedig a (4.5)-(4.7) egyenletek alapján került kiszámításra, ahol $N=6$ és $w=0,2 \mathrm{~Hz}$.

A jel-zaj viszonyon alapuló spektrális indikátorok meghatározásának alapvető kérdése, hogy hogyan definiáljuk a hasznos jelet és a zajt. A mozgásjelek egy periódusának alakja meghatározza a teljesítménysűrűség-spektrumban a felharmonikusok magnitúdóját, illetve a zajszintből jelentősen kiemelkedő felharmonikus csúcsok számát. Bár a jelek periodikus komponenseit - illetve ezek zajhoz való viszonyát - vizsgáljuk, melyet az alap- és felharmonikusok határoznak 
meg, a különböző sportolók esetén számított spektrumok összehasonlítása megmutatta, hogy a felharmonikusok száma összefügghet egy technikai hiba jelenlétével, mely időtartományban az x irányú gyorsulásjel hirtelen le- és felugrásaiban mutatkozott meg, ahogyan a 4.7. ábrán is láthattuk $[9,89]$. Ez a megfigyelés rávilágít arra, hogy a felharmonikusok által meghatározott jelteljesítmény, bár a periodikus, de nem kizárólag az optimális mozgáskomponensekhez tartozik. Továbbá, az evezési frekvencia - éppen a periódusidő fluktuációjából adódóan - kis mértékben ingadozhat a vizsgált, 30 másodperces időintervallumok alatt is, mely a csúcsok kiszélesedéséhez vezet. Emiatt a komplex jelalakokból következő, jelentősen változó méretű csúcsok szeparálása a spektrum további elemeiből - ahogyan a 4.15. ábrán is látható - igen összetett feladat.

A megfelelő indikátorok megállapításához megvizsgáltam, hogyan érdemes a

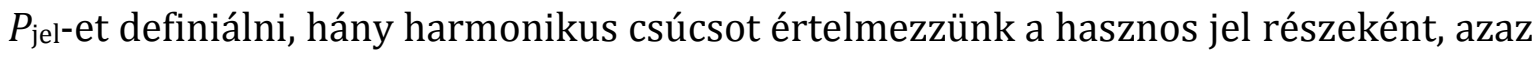
a (4.6) egyenletben szereplő $N$ különböző értékeire teszteltem az indikátorok és a technikai szint kapcsolatát. Ahogyan az előbbiekben láthattuk, három jel esetén az egykezes evezéshez tartozó frekvenciaértéknél található a domináns csúcs, ezért a jelek egységes kezeléséhez az első két csúcsot, azaz az alap- és első felharmonikust minden esetben a hasznos jel részének tekintettem. A numerikus analízist számos különböző harmonikus-számra elvégeztem, ennek eredménye a 4.18. ábrán azonban két hasznos jel defínicó összevetésével szemléltethető. A sportolók teljesítménysűrűség-spektrumainak elemzése során az alapharmonikuson túl az első 5 felharmonikus különült el legtöbbször egyértelműen a többi spektrális komponenstől, azaz a következő két esetet tekinthetjük a megközelítés két végletének. Míg $N=2$ esetében csak az egy- és kétkezes periódushoz tartozó harmonikus, $N=6$ alkalmazásával a - legtöbb esetben - összes jelentős harmonikus által meghatározott teljesítmény összegét tekintjük hasznos jel teljesítményének. Mint a 4.18. ábrán látható, a csavarási szögsebességjelre meghatározott $S N R$ a felharmonikusok figyelembevételekor jelentősen erősebb kapcsolatot mutat a technikai szinttel.

A spektrumok osztályozásához, a spektrális csúcsok detektálásához vagy a megfelelő frekvenciasávok kiválasztásához felmerülhet komplex, például a spektrumok mintázatát osztályozó, tanuló algoritmusok alkalmazása is, azonban ahogy jelen esetben is - az ezek megfelelő működéséhez szükséges minta szám nem feltétlenül biztosítható. Továbbá munkám során egyszerű, mégis a különböző jelekre és evezési stílusokra is alkalmazható módszer kifejlesztésére törekedtem, amely esetében továbbá - ahogy $N$ értékének meghatározásánál is láthattuk - a mozgás peridocitására vonatkozó fizikai megközelítésünk értelmezhető marad.

Az időtartománybeli detektálás nélkül nincs lehetőségünk az átlagos evezési periódus alapján meghatározni az alapharmonikus frekvenciáját. A teljesítménysűrűség-spektrum alapján az alapharmonikus frekvencia a kétkezes 
periódusú jelek esetén a domináns csúcs által meghatározott frekvenciaérték, míg egykezes periódusú jelek esetén - jó közelítéssel - annak fele. Természetesen a gyakorlati esetben kiszélesedett csúcsok esetén a pontos frekvenciaérték meghatározása sem egyértelmű, azonban ennek meghatározása a teljesítménysűrűség-spektrum maximumához tartozó frekvenciaértékként az időtartománybeli vizsgálatok során kapott értékkel megfelelő egyezést mutatott.
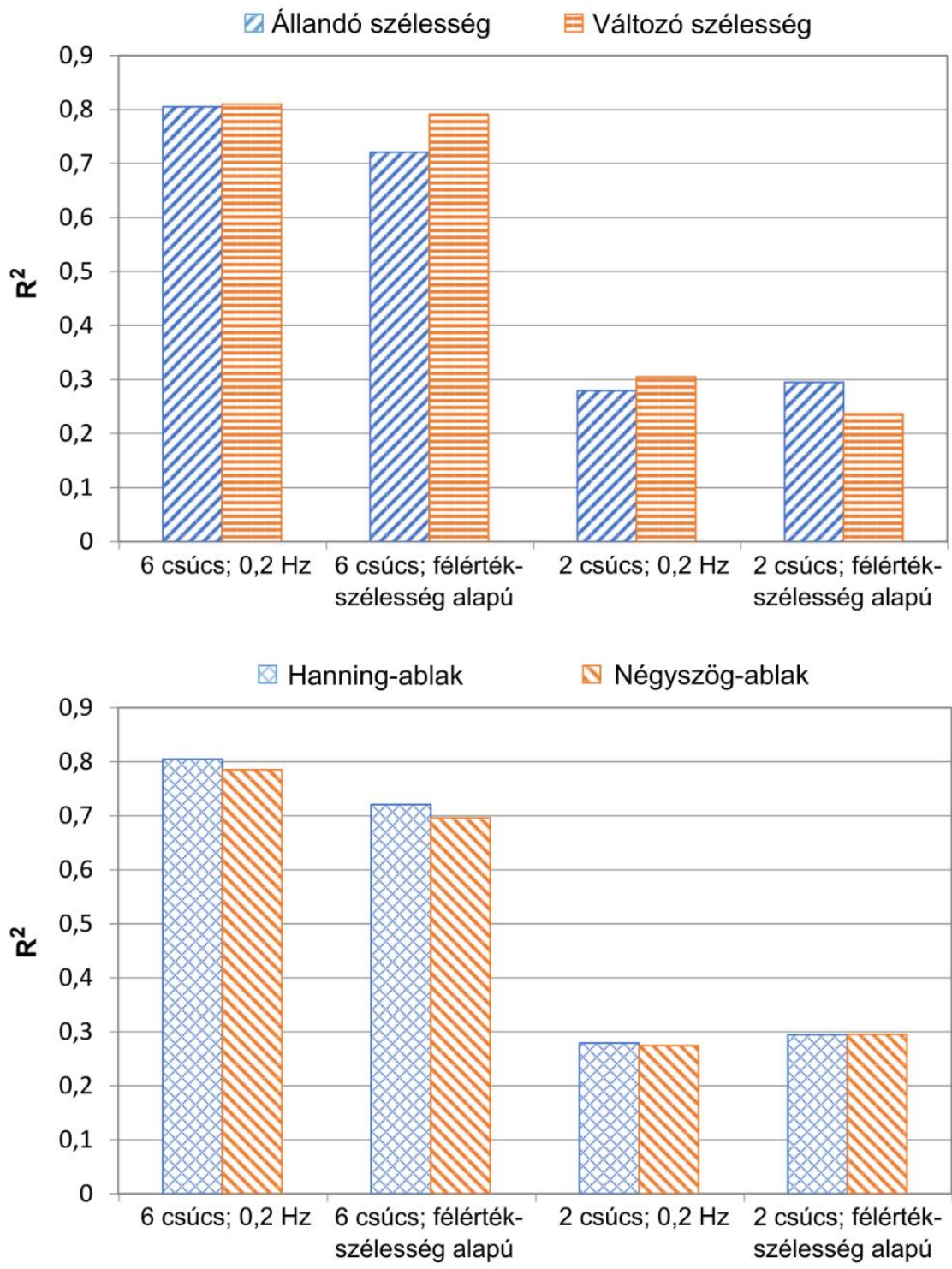

4.18. ábra: A technikai szint és a $S N R$ kapcsolatát leíró $R^{2}$ különböző $P_{\text {jel }}$ definíciók (különböző $N$ felharmonikus-szám és $w$ csúcsszélesség) esetén. Továbbá a minden harmonikus esetén állandó, illetve frekvenciafüggő, azaz változó $w$ szélesség (fent) és a Hanning- illetve négyszög-ablak (lent) hatásának összehasonlítása is látható.

A vizsgált frekvenciértékek meghatározása mellett ugyancsak kiemelten fontos kérdés, hogy azok milyen $w / 2$ környezetében végezzük el a numerikus integrálást. Az előbbi, egyszerű eljárásokra vonatkozó megállapítást szem előtt tartva a $w$ csúcsszélesség értékét különböző, a spektrumok alakjától független, előre rögzített 
értékekre teszteltem, mely során a 0,2 Hz-es szélesség adódott a legjobban alkalmazhatónak. Emellett egy, a $w$ értékét a domináns csúcs félérték-szélességének kétszereseként definiáló alapuló eljárást is fejlesztettem. Ahogyan a 4.18. ábrán látható, sziginifikáns különbség a kétféleképpen meghatározott csúcsszélesség között nem mutatkozzott az indikátorok minőségét illetően.

A $P_{\text {jel }}$ meghatározásánál a (4.6) egyenletben minden harmonikus csúcsot azonos, $w$ szélesnek tekintettünk, azonban, ha az alapharmonikus csúcs kiszélesedése az alapfrekvencia ingadozásából adódik, a felharmonikusok szélessége a (4.8) egyenletben látható módon, a frekvenciával arányosan növekedni fog:

$$
P_{\text {jel }}=\sum_{i=1}^{N} \int_{i \cdot f_{0}-\frac{i \cdot w}{2}}^{i \cdot f_{0}} \int_{i \cdot \frac{i \cdot w}{2}}^{2}(f) d f .
$$

Az indikátorokat ennek megfelelően a minden csúcs esetén állandó $w$ érték mellett annak előbbi módon való változtatása esetén is kiszámítottam. Ahogyan a 4.18. ábrán látható, a két módszer között jelentős különbség nem mutatkozott.

Természetesen az indikátorok értékét és így a technikai szinttel való kapcsolatuk mértékét is befolyásolja, hogy milyen módon számoljuk magát a teljesítménysűrűség-spektrumot. Ha nem egész számú periódusból áll a mozgásjel, a csúcsok kiszélesednek, melynek kezelésére különböző ablakfüggvények használatosak. A 4.18. ábrán látható, hogy a négyszög-ablakkal - azaz speciális ablakfüggvény alkalmazása nélkül - illetve az élettani jelek esetében is gyakran alkalmazott Hanning-ablakkal számított spektrumok esetén az indikátorok technikai képzettséggel való korrelációja nem különbözött szignifikánsan.

Ahogyan a 4.2.1. fejezetben említésre kerül, a vizsgált időablakok szélessége is befolyásolhatja eredményeinket. A nagyszámú evezést vizsgálva a 30 másodperces tartománytól nem volt lehetőségem nagyban eltérni, mivel jelentősen kisebb időablakra a spektrális felbontás már nem tette lehetővé a csúcsok numerikus vizsgálatát, nagyobb időablak esetén pedig jelentősebb mértékben is változhatott az evezési frekvencia. Ugyanakkor az időbeli detektálás kiváltására alkalmas módszer szempontjából fontos megemlíteni, hogy más jelek esetében az időablak helyes megválasztása igen fontos lehet.

\subsection{4 Összegzés, nyitott kérdések}

A kajakos sportolók evezése során mért mozgásjelek elemzése során láthattuk, hogy a mozgás periódusfluktuációi információt hordoznak az evezés technikai kivitelezésének minőségével kacsolatban. Újszerű megközelítésünk azon alapult, hogy az optimális előrehaladáshoz egyenletes evezés szükséges. Az analízis során az egyes evezéseket leíró, időtartományban megállapítható klasszikus mennyiségek 
variabilitását jellemző, és a jelek teljesítménysűrűség-spektruma alapján meghatározható jel-zaj viszonyon alapuló indikátorokat határoztam meg. A bemutatott eredmények alapján, a kis számú minta és a mérések során fellépő számos, nem mérhető külső körülmény ellenére egyértelműen megállapítható, hogy az indikátorok kapcsolatban állnak a sportolók technikai képzettségével.

A bemutatott vizsgálat során számos különböző módon számolt idő- és frekvenciatartománybeli indikátort vetettem össze. Az időtartománybeli vizsgálat során a mozgás teljes, kétkezes periódusára számolt mennyiségek (periódusidő és evezési impulzus) relatív szórása, míg a spektrális indikátorok esetén a kétkezes periódusú szögsebesség jelek jel-zaj viszonya mutatta a legerősebb kapcsolatot a tecnhikai szinttel. Ez alapján látható, hogy mozgás teljes, egy jobb- és egy balkezes húzás együttesét tartalmazó periódusa, és az ilyen periódusú mozgásjelek karakterizálják a legjobb módon az evezést.

A fluktuációanalízisen alapuló, újszerű megközelítés, ahogy az előzőekben is láthattuk, számos további érdekes nyitott kérdést vet fel, és további alkalmazási lehetőségeket rejt magában.

Egy adott versenyző felkészítése esetén szükséges lehet a teljesítmény és fizikai állapot részletes elemzése, melyhez számos mennyiség és fiziológiai paraméter együttes kiértékelése szükséges. A bevezetett indikátoroknak nem célja helyettesíteni egy ilyen vizsgálatot, azonban többletinformációt adhatnak a technikai kivitelezés minőségéről. Ennek fényében fontos kérdés, hogyan építhető be a sportolók teljesítményének átfogó elemzésébe, egy adott sportoló esetén milyen megbízhatósággal lehetséges a fejlődés vizsgálata az indikátorok napi vizsgálatával, és hogyan vethetőek össze különböző sportolók esetén.

A módszer kajak-kenu sportban való felhasználásának hatékonyságával illetve a módszerek továbbfejlesztésével kapcsolatban az egyik kulcskérdés, hogy mik a periódusfluktuációk forrásai? Milyen mértékben függ a fluktuáció az adott, sportolóra jellemző technikától, az abban jelentkező hibától, külső mechanikai effektusoktól vagy az aktuális fizikai és mentális állapottól? Egy konkrét, az evezés kivitelezésében megfigyelhető változás hogyan befolyásolja ezen indikátorokat?

A mentális állapot teljesítményre gyakorolt hatása jól ismert tényező, ugyanakkor összetett kérdés, ez hogyan befolyásolja a mozgásjelek fluktuációit. Más szemszögből tekintve a fluktuációanalízis hasznos lehet neurológai kutatások esetében is, melyek során gyakran különböző, periodikus mozdulatsorok kivitelezésének pontosságát mérik, az előzőekben pedig éppen a megfelelő mozdulatsor kivitelezésében fellépő különbségeket vizsgáltuk a fluktuációk elemzésével.

Számos idő- és frekvenciatartománybeli indikátort hasonlítottam össze, ugyanakkor lehetnek indikátorok, melyek még jobban karakterizálják az evezés minőségét. A jelenlegi és újabb mérőszámok teszteléséhez, az életkoron és edzői 
osztályozáson alapuló összehasonlításon túl más, például időeredmények alapján történő elemzéshez további szisztematikus vizsgálatok szükségesek.

A frekvenciatartománybeli vizsgálat során döntő fontosságú, hogy hogyan szeparáljuk a hasznos jelet és a zajt, ezért számos különböző megoldást is teszteltem a mért jeleken. Ha az egy evezéshez tartozó jelalak nem változik jelentősen húzásról húzásra, a periodikus mozgásjel jól közelíthető egy fluktuáló periódusidejű impulzussorozat és a periódus jelalakjának konvolúciójával, így a problémát jóval általánosabban is érdemes lehet vizsgálni, mind analitikus, mind numerikus módon. Ezen leírás, illetve szimulációk segítségével továbbfejleszthető a jel-zaj viszonyon alapuló variabilitás-vizsgáltunk.

A fluktuációanalízis alkalmazásának ötlete a periodikus mozgás egyenletességének mérésén alapult. Periodikus mozgás kivitelezése szükséges számos más sportág, mint péládul a futás, keréppározás, korcsolyázás vagy úszás esetében is, így hasonló vizsgálat ezen területeken is lehetséges. A módszer alkalmazható lehet továbbá olyan orvosdiagnosztikai vizsgálatok során, mint a járás egyenletességének, vagy, ahogy az előbbiekben említettük, különböző mozdulatsorok pontos végrehajtásának mérése. Az okostelefonok, -órák és -karkötők elterejedésével hasonló mozgásjelek, mint a bemutatatott kajakos méréseink esetében, hétköznapi környezetben is mérhetővé váltak, így a mozgást jellemző és egészségügyi paraméterek meghatározása ezen eszközökbe is implementálhatóak.

A variabilitást jellemző indikátor spektrális meghatározása számos más periodikus jel esetén is előremutató lehet, hiszen ezesetben nem szükséges a periódusok időbeli detektálása. Példaként tekinthetjük az élettani jelek esetén a szívritmus variabilitásának vizsgálatát, ahol a szívütések detektálásán túl problémát okoz a detektált szívütések közötti idő spektrális vizsgálata is, hiszen a kapott regisztrátum - éppen a fluktuációnak kösznhetően - nem egyenletesen mintavételezett.

Ezen megállapítások alapján mind a mozgásjelek periódusfluktuációinak idő- és frekvenciatartománybeli, mind a jel-zaj viszonyon alapuló spektrális módszer számos lehetőséget rejt magában, és jövőbeli kutatásaim tárgyát képezi.

A 4.2. fejezetben bemutatott eredményeimet az értekezés 4. tézispontja foglalja össze. 



\section{5 ÖSSZEFoglaLÁs}

Az értekezésben bemutatott, a véletlenszerú fluktuációk hasznosításának témakörében elért új, tudományos eredményeimet az alábbi négy tézispont foglalja össze. Az első három tézispont a zaj alapú abszolút biztonságos kommunikáció területén, a Kirchhoff-Law-Johnson-Noise (KLJN) kulcsmegosztó protokoll elméleti és numerikus vizsgálata során elért eredményeimet mutatja be, melyek három nemzetközi folyóiratcikkben és egy konferenciacikkben jelentek meg [1-4]. A negyedik tézispont a versenykajak periodikus mozgásjeleinek fluktuációanalízisével a sportolók teljesítményének értékelésére vonatkozó eredményeimet összegzi, melyeket egy meghívott előadáson alapuló nemzetközi folyóiratcikkben, illetve egy nemzetközi konferencián mutattam be $[5,6]$. A tézispontok végén megjelölt alátámasztó publikációk típusát, illetve azok tézispontokkal való kapcsolatát az 1.1 táblázat szemlélteti.

\section{A KLJN kulcsmegosztó protokoll abszolút biztonságosságához szükséges zajra vonatkozó követelmények bizonyítása}

A KLJN protokoll matematikai statisztikai eszközökkel való vizsgálatának korábbi, a klasszikus fizikai megközelítéssel egyező eredményei alapján az abszolút biztonságos kommunikáció szükséges feltétele, hogy az alkalmazott zajgenerátorok által előállított feszültségzajok normális eloszlásúak legyenek, varianciájuk pedig az ellenállások aránya szerint skálázódjon. E vizsgálatot a lehallgató által a kommunikációs vezetéken mérhető áram- és feszültségzaj együttes eloszlásának vizsgálatával egészítettük ki. Először a rendszer numerikus szimulációjával demonstráltam, hogy a rendszer 0 és 1 értékủ kulcsbiteknek megfeleltethető LH és HL állapotai a két említett feltételtől eltérő esetekben megkülönböztethetőek, azaz a kulcscsere lehallgatható. Ezután egy, két független valószínűségi változó lineáris kombinációinak függetlenségére vonatkozó tétel alapján megmutattam, hogy a zajparaméterekre vonatkozó előbbi két megkötés a protokoll abszolút biztonságosságának szükséges és elégséges feltétele, ezzel megadva a protokoll 
biztonságosságának klasszikus fizikai megfontolásokat mellőző, matematikai bizonyítását. [1]

\section{A KLJN kulcsmegosztó protokoll általánosítása}

$\mathrm{Az}$ eredeti protokoll szerint a két kommunikáló fél azonos értékű ellenálláspárokat használ, a biztonságosság pedig a lehallgató által mérhető mennyiségek függetlenségén alapszik. Rámutattam, hogy az LH és HL állapotok megkülönböztethetetlensége ennél jóval kevesebb megkötéssel is biztosítható. Az áram- és feszültségzajoknak nem kell függetlennek lenniük, elegendő, ha e két mennyiség együttes eloszlása is megegyezik a két esetben. Ez alapján megmutattam, hogy normális eloszlású feszültségzajok esetén az abszolút biztonságosság kritériuma a vezetéken mérhető áram- és feszültségzajok varianciájának és korrelációjának egyenlősége LH és HL állapotban, mely teljesíthető egy jóval általánosabb rendszer esetén is, melyben mindkét fél tetszőleges ellenálláspárt használ. Az új kritériumok alapján formulát adtam a zajgenerátorok effektív értékeire, melyekkel az általánosított rendszer abszolút biztonságos. Eredményeimet numerikus szimulációkkal is igazoltam. Az eredeti KLJN rendszer annak a speciális, szimmetrikus esetnek felel meg, melyben a lehallgató által mérhető két mennyiség nem korrelál, azaz nincs energiaáramlás a két fél között, a rendszer termikus egyensúlyban van. A protokoll általánosításával rámutattam, hogy ez a megkötés nem szükséges az abszolút biztonságos kommunikáció megvalósításához. Ez a KLJN protokoll biztonságosságára vonatkozó klasszikus fizikai leírás újraértelmezését és új protokollok bevezetését eredményezte. Az új kulcsmegosztó protokoll, melyben a két kommunikáló fél rendszerének nem kell megegyeznie, jelentősen megkönnyíti a hardver megvalósítását és gyakorlatban való implementációját. [2]

\section{3. Általánosított KLJN kulcsmegosztó rendszer gyakorlati alkalmazásokhoz}

Az általánosított KLJN rendszer modelljét kiegészítettük a kommunikációs vezeték ellenállásával, melyen a lehallgató bárhol végezhet mérést. Megmutattam, hogy az abszolút biztonságosságot garantáló, a 2. tézispontban is alkalmazott feltételek ezen rendszer esetén is teljesíthetőek. Megadtam a feszültségzajok varianciájára vonatkozó formulákat, melyekből látható, hogy a zajgenerátorok biztonságossághoz szükséges effektív értéke nem függ a lehallgató megfigyelési pontjától. Az abszolút biztonságosság a vezeték teljes hosszán garantált; bár különböző pontjain eltér a feszültség és áramerősség korrelációjának értéke, azonban biztosítható, hogy az megegyezzen az LH és HL esetekben. Az eredeti rendszer esetén az ideálistól való eltérés, a vezeték és további, a gyakorlati megvalósításhoz szükséges komponensek ellenállása információszivárgást okozott. Ezzel szemben e komponensek az új rendszer részét képezik ideális esetben is, amely a zajparaméterek megfelelő beállítása esetén abszolút biztonságos, így az általános 
védelmet nyújt a statikus esetben való támadásokkal szemben. Ez alapján a valós fizikai rendszerek komponensei által okozott hibát teljes mértékben, akár valós időben detektálni és kompenzálni képes protokoll jelentős mértékben megkönnyíti és elősegíti az eljárás gyakorlati alkalmazását. A rendszer biztonságosságát numerikus szimulációval is igazoltam, továbbá megvizsgáltam, hogy a valós implementáció során használt alkatrészek pontatlansága milyen mértékű információszivárgást okoz. [3, 4]

\section{Kajakos sportolók teljesítményének értékelése a mért mozgásjelek fluktuációanalízisével}

Kajakos sportolók evezésének vizsgálata kapcsán, a versenykajak mért mozgásjeleinek elemzése során megmutattam, hogy a mozgást jellemző periódusidő és a periodikus jelalakot jellemző evezési impulzus fluktuációja kapcsolatban áll az evezés minőségével, így az ingadozást jellemző időbeli, illetve a nyers mozgásjelek jelzaj viszonyán alapuló frekvenciatartománybeli indikátorok többletinformációt hordozhatnak.

Az evezést, azaz a mozgásjelek egy periódusát jellemző klasszikus paraméterek értékének időbeli változását trendgörbéken és Poincaré diagrammon ábrázolva rámutattam, hogy azok ingadozása kapcsolatban áll a sportolók technikai képzettségével. Ezen kapcsolat vizsgálatához az evezési periódus és impulzus szórásán alapuló többféle indikátort, és a meghatározásukhoz szükséges numerikus módszert hasonlítottam össze. A legszorosabb összefüggést a mindkét kézzel történő evezési periódus evezési impulzusának relatív szórása mutatta.

A nyers mozgásjelek teljesítménysűrűség-spektruma alapján számolt jel-zaj viszonyon alapuló módszert vezettem be, melynek előnye, hogy nem kell az egyes periódusokat időtartományban detektálni, továbbá a menetirányú gyorsulás mellett a többi gyorsulás és szögsebesség jel fluktuációanalízise is lehetséges. Különböző jel és zaj szeparálási módszereket és az ezek meghatározásához szükséges számos különböző numerikus eljárást hasonlítottam össze mind a hat mozgásjel esetén. A mindkét kézzel való evezési periódushoz tartozó jelek esetén e kapcsolat jóval szorosabbnak mutatkozott.

Az indikátorok és a 14 különböző technikai képzettségű sportoló életkorának és edzői értékelésének korrelációja alapján kapcsolat mutatkozik a technikai képzettség és periódusfluktuációk között. Az eredmények számos érdekes, nyitott kérdésre világítanak rá, melyek további kutatások alapjául szolgálhatnak. A megközelítés más periodikus mozgások esetében is alkalmazható lehet, a variabilitás spektrális vizsgálata pedig további periodikus, például élettani jelek esetén is új eredményeket rejt magában. [5, 6] 



\section{SUMMARY}

My new scientific results in the application of random fluctuations presented in the dissertation are summarized in the four thesis statements below. The first three points describe my results in theoretical and numerical analysis of the KirchhoffLaw-Johnson-Noise (KLJN) secure key exchange protocol in the field of noise based unconditionally secure communication. These were published in three international journal articles and an international conference article [1-4]. The fourth point summarizes my results in evaluating kayak paddlers' performance by fluctuation analysis of the periodic motion signals, which were published in an international journal article (based on an invited talk) and an international conference article [5, 6]. The type of the supporting publications - referenced at the end of each point - and their connection with the thesis statements are shown in Table 1.1.

\section{Proof of the noise requirements for unconditionally secure communication with the KLJN secure key exchange system}

According to the earlier results of the KLJN protocol's examination with mathematical statistical tools the necessary conditions for unconditionally secure communication - in agreement with the results of the classical physical approach are that noise generators produce normally distributed voltage noises whose variances are scaled with the ratio of the resistances. We have complemented the analysis with the examination of the joint probability distributions of the voltage and current noise measured by the eavesdropper. First, I demonstrated by numerical simulation of the system that the LH and HL states assigned to the 0 and 1 key bits are distinguishable making the exchange insecure in cases with the two above conditions unmet. Then I showed using the theorem regarding the independence of the linear combination of two independent random variables that the two requirements of the noise parameters are necessary and sufficient for the unconditional security of the protocol. With this I have given the mathematical proof of the protocol's security without classical physical considerations. [1] 


\section{Generalization of the KLJN key exchange protocol}

The original protocol requires the two communicating parties to use the same resistor pairs basing the security on the independence of the quantities measurable by the eavesdropper. I showed that the indistinguishability of the LH and HL states can be ensured with significantly less limitations. The independence of the current and voltage noises is not required, it is enough that their joint distributions are equal in the two cases. Based on this I showed that the condition for unconditional security in the case of normally distributed voltage noises is the equality of the variances and correlation of the measurable current and voltage noises in the LH and HL states. This can be accomplished with a much more general system in which the two parties are using two different sets of resistor pairs. I gave the formulas for the effective values of the noise generators based on the new criteria which make the generalized system unconditionally secure. I have verified these results by numerical simulations as well. The original KLJN system corresponds to the symmetrical case in which the two quantities measurable by the eavesdropper do not correlate, i.e. there is no power flow between the two parties, the system is in a thermal equilibrium. I showed by the generalization of the protocol that this condition is not necessary to achieve unconditional security. This resulted in the reinterpretation of the classical physical description of the KLJN protocol's security and the introduction of new protocols. The new key exchange protocol in which the two communicating parties' system does not have to be equivalent simplifies the hardware's realization and practical implementation greatly. [2]

\section{Generalized KLJN key exchange for practical applications}

We complemented the model of the generalized KLJN system with the communication wire's resistance on which the eavesdropper can make measurements at any position. I showed that the conditions guaranteeing the unconditional security (used in the 2. point) can be satisfied in this system as well. I gave the equations for the variance of the voltage noises, which show that the noise generators' required effective values do not depend on the observation point of the eavesdropper. The security is maintained over the full length of the interconnecting cable; the correlation of the voltage and current is different at different points of the cable, however it can be assured to be equivalent in LH and HL states. In the original system deviation from the ideal case - resistance of the wire and other components necessary for practical implementation - resulted in information leakage. In contrast these components are part of the new system in the ideal case as well which is unconditionally secure if the noise parameters are correctly set, providing general protection against attacks in static case. Therefore, this protocol, which is capable of completely detecting and compensating errors caused by components of real physical 
systems even in real time, simplifies and facilitates the practical application of the method. I have verified the security of the system by numerical simulation as well. Furthermore, I investigated the extent of information leakage caused by the tolerance of the components used in the real physical implementation. [3, 4]

\section{Performance estimation of kayak paddlers based on fluctuation analysis of movement signals}

While analyzing the performance of kayak paddlers through the movement signals of the kayak I showed that the quality of the paddling is correlated to the fluctuations of the period and stroke impulse, which characterise the period of the motion. This means that indicators of that fluctuation - based on temporal variability or the signal-to-noise ratio calculated from the power spectra of the raw movement signals- could contain additional information.

I showed by plotting the temporal change of the classical parameters characterizing the period of the motion signals on trend curves and Poincaré plots that their fluctuations are connected to the technical skills of the athletes. For the examination of this connection I compared multiple indicators - based on the standard deviation of the stroke period and stroke impulse - and the numerical methods required for determining them. The strongest correlation was shown by the relative standard deviation of the stroke period's stroke impulse while paddlers were pulling with both hands.

I introduced a method based on the signal-to-noise ratio calculated from the power spectral density of the raw motion signals. The benefits of this method are that the peak detection in time domain can be eliminated, and that it allows the fluctuation analysis of the other acceleration and angular velocity signals besides the use of the forward axis acceleration signal. I compared different signal and noise separation methods and multiple numerical procedures for determining them for each of the six movement signals. There was a much stronger correlation in the case of the signals when the athletes were pulling with both hands.

A connection was shown between the technical skills and the period fluctuations based on the correlation of the indicators and the age and classification of the 14 paddlers with different age and different levels of training. Our results raise a number of interesting, open questions which could be the subject of further research. The approach could be applied to other periodic movements and the presented method of spectral variability analysis might also include new results for other periodic - eg. physiological - signals. [5, 6] 



\section{KöSZÖNETNYILVÁNÍTÁS}

Köszönöm témavezetőmnek, Dr. Gingl Zoltánnak, hogy elindított kutatói és oktatói pályámon. Kutatócsoportjában számos izgalmas problémával foglalkozhattam és az évek során a szakmai kérdéseken túl is rendkívül sokat tanulhattam tőle. Köszönettel tartozom Dr. Mingesz Róbertnek a kutatási és oktatási feladatok során nyújtott széleskörű segítségéért és támogatásáért. Köszönöm Makan Gergelynek a közös munkánk során, illetve az értekezés átolvasásában nyújtott segítségét és támogatását. Hálával tartozom Bors Noéminek az értekezés tüzetes átolvasásáért és tanácsaiért. Köszönöm Dr. Németh L. Zoltánnak a kriptográfiai eljárásokkal kapcsolatos hasznos tanácsait. Köszönettel tartozom Mellár Jánosnak, továbbá a Műszaki Informatika Tanszéken dolgozó kollégáimnak és a "Zajlabor"-ban dolgozó hallgatóknak a mindennapokat jellemző barátságos légkörért.

Köszönöm minden társszerzőmnek azt, amit közös munkánk során tőlük tanulhattam, és köszönöm az EDF Démász Szeged Vízisport Egyesület sportolóinak és edzőinek a közös munka során nyújtott segítséget.

Végül, de korántsem utolsó sorban köszönöm szüleimnek, testvéreimnek és barátaimnak, hogy végig támogattak és bátorítottak az idáig vezető úton.

Az értekezésben bemutatott kutatások egy része az alábbi projektek támogatásával valósult meg:

- „Telemedicina fókuszú kutatások Orvosi, Matematikai és Informatikai tudományterületeken" (TÁMOP-4.2.2.A-11/1/KONV-2012-0073),

- „Élő dolgok Internete (Internet of Living Things)” (GINOP-2.3.2-15-2016-00037),

- Dr. Mingesz Róbert „Zajok és véletlen jelenségek interdiszciplináris területeken való alkalmazásának kutatása és oktatása” kutatási programja, amely a „Nemzeti Kiválóság Program - Hazai hallgatói, illetve kutatói személyi támogatást biztosító rendszer kidolgozása és múködtetése konvergencia program" keretében valósult meg (TÁMOP-4.2.4.A/2-11/1-2012-0001). 



\section{IRODALOMJEGYZÉK}

\section{Az értekezés alapjául szolgáló közlemények}

[1] R Mingesz, G Vadai, Z Gingl, What kind of noise guarantees security for the Kirchhoff-Law-Johnson-Noise key exchange? FLUCTUATION AND NOISE LETTERS 13:(3) Paper 1450021, 7 p. (2014)

[2] G Vadai, R Mingesz, Z Gingl, Generalized Kirchhoff-Law-Johnson-Noise (KLJN) secure key exchange system using arbitrary resistors. SCIENTIFIC REPORTS 5: Paper 13653, 7 p. (2015)

[3] G Vadai, Z Gingl, R Mingesz, Generalized attack protection in the Kirchhoff-LawJohnson-Noise secure key exchanger. IEEE ACCESS 4: pp. 1141-1147 (2016)

[4] R Mingesz, N Bors, G Vadai, Z Gingl, Performance and security analysis of the generalized Kirchhoff-Law-Johnson-Noise key exchange protocol. In Proceedings of 24th International Conference on Noise and Fluctuations (ICNF) Vilnius, Lithuania, 2017.06.20-23. IEEE, pp. 200-203.

[5] G Vadai, Z Gingl, R Mingesz, G Makan, Performance estimation of kayak paddlers based on fluctuation analysis of movement signals. In L Varani (ed.): Proceedings of 22nd International Conference on Noise and Fluctuations (ICNF), Montpellier, France, 2013.06.24-28. IEEE, Paper 6579010, 4 p.

[6] G Vadai, Z Gingl, Can the fluctuations of the motion be used to estimate performance of kayak paddlers? JOURNAL OF STATISTICAL MECHANICS: THEORY AND EXPERIMENT 2016: Paper 054040, 10 p. (2016), based on an invited talk presented at the 7th International Conference on Unsolved Problems on Noise, Barcelona, Spain, 2015.07.13-17. 


\section{Kapcsolódó közlemények}

[7] R Mingesz, Z Gingl, G. Vadai, Security and performance analysis of the KirchhoffLaw-Johnson-Noise (KLJN) secure key exchange protocol. In Proceedings of 23rd International Conference on Noise and Fluctuations (ICNF), XI'An, China, 2015.06.2-5. IEEE, 4 p.

[8] LB Kish, Z Gingl, R Mingesz, G Vadai, J Smulko, CG Granqvist, Analysis of an Attenuator Artifact in an Experimental Attack by Gunn-Allison-Abbott Against the Kirchhoff-Law-Johnson-Noise (KLJN) Secure Key Exchange System. FLUCTUATION AND NOISE LETTERS 14:(1) Paper 1550011, 8 p. (2015)

[9] G Vadai, G Makan, Z Gingl, R Mingesz, J Mellár, T Szépe, A Csamangó, On-water measurement and analysis system for estimating kayak paddlers' performance. In Proceedings of 36th Int. Conv., Microelectronics, Electronics and Electronic Technology, Opatija, Croatia, 2013.05.20-24, IEEE, pp. 144-149.

\section{Felhasznált irodalom}

[10] Z Gingl, R Mingesz, G Vadai, KSz Balogh, Á Erdélyi, Fluctuation enhanced gas detector for wireless sensor networks. In L Varani (ed.): Proceedings of 22nd International Conference on Noise and Fluctuations (ICNF), Montpellier, France, 2013.06.24-28, IEEE, Paper 6578901, 5 p.

[11] R Mingesz, G Vadai, Z Gingl, Power spectral density estimation for wireless fluctuation enhanced gas sensor nodes. FLUCTUATION AND NOISE LETTERS 13:(2) Paper 1450011, 14 p. (2014)

[12] R Mingesz, G Vadai, Z Gingl, Wireless sensor node for fluctuation enhanced sensing. 39th International Microelectronics and packaging IMAPS Poland Conference, Gdansk, Poland, 2015.09.20-23.

[13] R Mingesz, G Makan, B Balogh, G Vadai, Z Gingl, IoT framework for Fluctuation Enhanced Sensing. In Proceedings of 24th International Conference on Noise and Fluctuations (ICNF), Vilnius, Lithuania, 2017.06.20-23. IEEE, pp. 261-264.

[14] Simon S Haykin: Communication systems (4th edition), 2008, John Wiley \& Sons, pp. 488-499.

[15] W Kester, ADC input noise: The good, the bad and the ugly. Is no noise good noise? ANALOG DIALOGUE 40:(2) pp. 13-17 (2006)

[16] Gingl Zoltán, Makra Péter, Mingesz Róbert, Kish László: Zajok és fluktuációk fizikai és biológiai rendszerekben, In Hevesi Imre (szerk.): Doktori (PhD)kurzusok fizikából (a. rész), Szeged, 2012, SZEK JGYF Kiadó. 
[17] R Benzi, G Parisi, A Sutera, A Vulpiani, Stochastic resonance in climate change. TELLUS 34:(1) pp. 10-16 (1982)

[18] K Wiesenfeld, F Moss, Stochastic resonance and the benefits of noise: from ice ages to crayfish and SQUIDs, NATURE 373: pp. 33-36 (1995)

[19] MD McDonnell, D Abbott, What Is Stochastic Resonance? Definitions, Misconceptions, Debates, and Its Relevance to Biology, PLOS COMPUTATIONAL BIOLOGY 5: e10003, 9 p. (2009)

[20] LB Kish, Noise-based logic: Binary, multi-valued, or fuzzy, with optional superposition of logic states. PHYSICS LETTERS A, 373:(10) pp. 911-918, (2009)

[21] LB Kish, Totally secure classical communication utilizing Johnson(-like) noise and Kirchhoff's law. PHYSICS LETTERS A, 352:(3) pp. 178-182 (2006)

[22] Z Chobola, Noise as a tool for non-destructive testing of single-crystal silicon solar cells. MICROELECTRONICS RELIABILITY 41:(12) pp. 1947-1952 (2001)

[23] LB Kish, R Vajtai, CG Granqvist, Extracting information from noise spectra of chemical sensors: single sensor electronic noses and tongues. SENSORS AND ACTUATORS B 71:(1-2) pp. 55-59 (2000)

[24] A Derekas, GM Szabó, L Berdnikov, R Szabó, R Smolec, LL Kiss, L Szabados, M Chadid, NR Evans, K Kinemuchi, JM Nemec, SE Seader, JC Smith, P Tenenbaum, Period and light-curve fluctuations of the Kepler Cepheid V1154 Cygni. MONTHLY NOTICES OF THE ROYAL ASTRONOMICAL SOCIETY 425:(2) pp. 13121319 (2012)

[25] OV Thorsen, M Dalva, A survey of faults on induction motors in offshore oil industry, petrochemical industry, gas terminals, and oil refineries. IEEE TRANSACTIONS ON INDUSTRY APPLICATIONS 31:(5) pp. 1186-1196 (1995)

[26] B Liang, BS Payne, AD Ball, SD Iwnicki, Simulation and fault detection of threephase induction motors. MATHEMATICS AND COMPUTERS IN SIMULATION 61:(1) pp. 1-15 (2002)

[27] JM Hausdorff, Gait dynamics, fractals and falls: finding meaning in the stride-tostride fluctuations of human walking. HUMAN MOVEMENT SCIENCE 26:(4) pp. 555-589 (2007)

[28] U Rajendra Acharya, K Paul Joseph, N Kannathal, C Lim, JS Suri, Heart rate variability: a review. MEDICAL AND BIOLOGICAL ENGINEERING AND COMPUTING 44:(12) pp. 1031-1051 (2006)

[29] Rényi Alfréd: Valószínűségszámítás, Budapest, 1968, Tankönyvkiadó. 
[30] Prékopa András: Valószínűségelmélet műszaki alkalmazásokkal, Budapest, 1962, Műszaki Könyvkiadó.

[31] Schnell László (főszerk.): Jelek és rendszerek méréstechnikája Budapest, 1985, Műszaki Könyvkiadó.

[32] Kemény Sándor, Deák András: Mérések tervezése és eredmények kiértékelése, Budapest, 1990, Műszaki Könyvkiadó.

[33] W Feller: An introduction to probability theory and its applications, Vol. 1 and Vol. 2, 1968, 1971, John Wiley \& Sons.

[34] L Isserlis, On a formula for the product-moment coefficient of any order of a normal frequency distribution in any number of variables. BIOMETRIKA 12:(12) pp. 134-139 (1918)

[35] E Lukacs, EP King, A Property of Normal Distribution. THE ANNALS OF MATHEMATICAL STATISTICS 25 pp. 389-394 (1954)

[36] William Stallings: Cryptography and Network Security, 4th Edition, 2006, Prentice Hall.

[37] Virrasztó Tamás: Titkosítás és adatrejtés: Biztonságos kommunikáció és algoritmikus adatvédelem, Budapest, 2004, NetAcademia Kft.

[38] Bruce Schneier: Applied Cryptography: Protocols, Algorithms, and Source Code in C, Second Edition, New York, 1996, John Wiley and Sons.

[39] Buttyán Levente, Györfi László, Györi Sándor, Vajda István: Kódolástechnika, 2006, Online: http://www.hit.bme.hu/ buttyan/publications/bscinfkod.pdf

[40] W Diffie, M Hellman, New directions in cryptography. IEEE TRANSACTIONS ON INFORMATION THEORY ARCHIVE 22:(6) pp. 644-654 (1976)

[41] PW Shor, Polynomial-Time Algorithms for Prime Factorization and Discrete Logarithms on a Quantum Computer. SIAM JOURNAL ON COMPUTING 26:(5) pp. 1484-1509 (1997)

[42] C Shannon, Communication Theory of Secrecy Systems. BELL SYSTEM TECHNICAL JOURNAL 28:(4) pp. 656-715 (1949)

[43] CH Bennett, G Brassard, Quantum cryptography: Public key distribution and coin tossing. In Proceedings of IEEE Int. Conf. Computers, Systems, and Signal Processing Bangalore, India, 1984, pp. 175-179.

[44] HP Yuen: Security of Quantum Key Distribution. IEEE ACCESS 4: pp. 724-749 (2016) 
[45] LB Kish: The Kish Cypher: The Story of KLJN for Unconditional Security, 2016, World Scientific

[46] I Gerhardt, Q Liu, A Lamas-Linares, J Skaar, C Kurtsiefer, V Makarov, Full-field implementation of a perfect eavesdropper on a quantum cryptography system. NATURE COMMUNICATIONS 2: 3496 p. (2011)

[47] A Cho, Simple Noise May Stymie Spies Without Quantum Weirdness. SCIENCE 309:(5744) pp. 2148 (2005)

[48] LB Kish, CG Granqvist, On the security of the Kirchhoff-law-Johnson-noise (KLJN) communicator. QUANTUM INFORMATION PROCESSING 13:(10) pp. 2213-2219 (2014)

[49] R Mingesz, Z Gingl, LB Kish, Johnson(-like)-noise-Kirchhoff-loop based secure classical communicator characteristics, for ranges of two to two thousand kilometers, via model-line. PHYSICS LETTERS A 372:(7) pp. 978-984 (2008)

[50] HP Chen, M Mohammad, LB Kish, Current injection attack against the KLJN secure key exchange. METROLOGY AND MEASUREMENT SYSTEMS 23:(2) pp. 173-181 (2015)

[51] LB Kish, Protection against the man-in-the-middle-attack for the Kirchhoff-loopJohnson(-like)-noise cipher and expansion by voltage-based security. FLUCTUATION AND NOISE LETTERS 6:(1) pp. L57-L63 (2006)

[52] J Scheuer, A Yariv, A classical key-distribution system based on Johnson (like) noise-How secure? PHYSICS LETTERS A 359:(6) pp. 737-740 (2006)

[53] LB Kish, Response to Scheuer-Yariv: 'A classical key-distribution system based on Johnson (like) noise-How secure?' PHYSICS LETTERS A 359:(6) pp. 741744 (2006)

[54] LB Kish, J Scheuer, Noise in the wire: The real impact of wire resistance for the Johnson(-like) noise based secure communicator. PHYSICS LETTERS A 374:(21) pp. 2140-2142 (2010)

[55] LB Kish, J Scheuer, Noise in the wire: The real impact of wire resistance for the Johnson(-like) noise based secure communicator. PHYSICS LETTERS A 374:(21) pp. 2140-2142 (2010)

[56] LB Kish, CG Granqvist, Elimination of a Second-Law-Attack, and all cableresistance-based attacks, in the Kirchhoff-Law-Johnson-Noise (KLJN) secure key exchange system. ENTROPY 16:(10) pp. 5223-5231 (2014)

[57] F Hao, Kish's key exchange scheme is insecure. IEE PROCEEDINGS INFORMATION SECURITY. 153:(4) pp. 141-142 (2006) 
[58] LB Kish, Response to Feng Hao's paper 'Kish's key exchange scheme is insecure,'. FLUCTUATION AND NOISE LETTERS 6:(4) pp. C37-C41, (2006)

[59] HP Chen, E Gonzalez, Y Saez, LB Kish, Cable Capacitance Attack against the KLJN Secure Key Exchange. INFORMATION 6:(4) pp. 719-732 (2015)

[60] PL Liu, A new look at the classical key exchange system based on amplified Johnson noise. PHYSICS LETTERS A 37:(10) pp. 901-904 (2009)

[61] LB Kish, T Horvath, Notes on recent approaches concerning the Kirchhoff-lawJohnson-noise-based secure key exchange. PHYSICS LETTERS A 373:(32) pp. 2858-2868 (2009)

[62] T Horvath, LB Kish, J Scheuer, Effective Privacy Amplification for Secure Classical Communications. EPL (FORMERLY EUROPHYSICS LETTERS) 94:(2) 28002 (2011)

[63] LJ Gunn, A Allison, D Abbott, A new transient attack on the Kish key distribution system. IEEE ACCESS 3: pp. 1640-1648 (2015)

[64] CH Bennett, CJ Riedel, On the security of key distribution based on JohnsonNyquist noise. Online: http://arxiv.org/abs/1303.7435 (2013)

[65] LB Kish, D Abbott, CG Granqvist, Critical analysis of the Bennett-Riedel attack on secure cryptographic key distributions via the Kirchhoff-law-Johnson-noise scheme. PLOS ONE 8:(12) e81810 15 p. (2013)

[66] LJ Gunn, A Allison, D Abbott, A directional wave measurement attack against the Kish key distribution system. SCIENTIFIC REPORTS 4: 6461 (2014)

[67] HP Chen, LB Kish, CG Granqvist, G Schmera, On the 'cracking' scheme in the paper 'a directional coupler attack against the Kish key distribution system' by Gunn, Allison and Abbott. METROLOGY AND MEASUREMENT SYSTEMS 21:(3) pp. 389-400 (2014)

[68] HP Chen, LB Kish, CG Granqvist, G Schmera, Do electromagnetic waves exist in a short cable at low frequencies? What does physics say? FLUCTUATION AND NOISE LETTERS 13:(2) 145001613 p. (2014)

[69] LB Kish, O Saidi, Unconditionally secure computers, algorithms and hardware, such as memories, processors, keyboards, flash and hard drives. FLUCTUATION AND NOISE LETTERS 8:(2) pp. L95-L98 (2008)

[70] Y Saez, X Cao, LB Kish G. Pesti, Securing vehicle communication systems by the KLJN key exchange protocol. FLUCTUATION AND NOISE LETTERS 13:(3) 1450020514 p. (2014) 
[71] E Gonzalez, LB Kish, Key exchange trust evaluation in peer-to-peer sensor networks with unconditionally secure key exchange. FLUCTUATION AND NOISE LETTER 15:(1) 165000817 p. (2016)

[72] LB Kish, K Entesari, CG Granqvist, C Kwan, Unconditionally Secure Credit/Debit Card Chip Scheme and Physical Unclonable Function. FLUCTUATION AND NOISE LETTERS 16:(1) 17500028 p. (2017)

[73] E Gonzalez, LB Kish, RS Balog, P Enjeti, Information theoretically secure, enhanced Johnson noise based key distribution over the smart grid with switched filters. PLOS ONE 8:(7) 7020610 p. (2013)

[74] LB Kish, C Kwan, Physical unclonable function hardware keys utilizing Kirchhoff-law-Johnson-noise secure key exchange and noise-based logic. FLUCTUATION AND NOISE LETTERS 12:(2) 1350018 11p. (2013)

[75] PL Liu, A key agreement protocol using band-limited random signals and feedback. JOURNAL OF LIGHTWAVE TECHNOLOGY 27:(23) pp. 5230-5234 (2009)

[76] PL Liu, Prediction accuracy of band-restricted random signals and security risk in statistical key exchange. FLUCTUATION AND NOISE LETTERS 9:(4) pp. 413422 (2010)

[77] LB Kish, Enhanced Secure Key Exchange Systems Based on the Johnson- Noise Scheme. METROLOGY AND MEASUREMENT SYSTEMS 20:(2) pp. 191-204 (2013)

[78] Z Gingl, R Mingesz, Noise properties in the ideal Kirchhoff-Law-Johnson-noise secure communication system. PLOS ONE 9:(4) e96109 4 p. (2014)

[79] A Zaj és nemlinearitás kutatócsoport KLJN protokollal kapcsolatos aktuális eredményeit közlő honlap: http://www.noise.inf.u-szeged.hu/Research/kljn/

[80] LB Kish, CG Granqvist, Random-resistor-random-temperature KLJN key exchange. METROLOGY AND MEASUREMENT SYSTEMS 23:(1) pp. 3-11 (2016)

[81] LB Kish, CG Granqvist, Comments on "A New Transient Attack on the Kish Key Distribution System", METROLOGY AND MEASUREMENT SYSTEMS 23:(3) pp. 321-331 (2016)

[82] D Paprika, Z Gingl, L Rudas, É Zöllei, Hemodynamic effects of slow breathing: Does the pattern matter beyond the rate? ACTA PHYSIOLOGICA HUNGARICA 101:(3) pp. 273-281 (2014)

[83] JK Ochab, J Tyburczyk, E Beldzik, et al., Scale-free fluctuations in behavioral performance: delineating changes in spontaneous behavior of humans with induced sleep deficiency. PLOS ONE 9:(9) e107542 12 p. (2014) 
[84] R Robillard, SL Naismith, KL Smith, NL Rogers, D White, Z Terpening, TKC Ip, DF Hermens, B Whitwell, EM Scott, IB Hickie, Sleep-wake cycle in young and older persons with a lifetime history of mood disorders. PLOS ONE 9:(2) e87763 8 p. (2014)

[85] S Lemola, T Ledermann, EM Friedman, Variability of sleep duration is related to subjective sleep quality and subjective well-being: an actigraphy study. PLOS ONE 8:(8) e71292 9 p. (2013)

[86] A Király, IM Jánosi, Stochastic modeling of daily temperature fluctuations. PHYSICAL REVIEW E 65:(5) 051102 (2002)

[87] P Talkner, RO Weber, Power spectrum and detrended fluctuation analysis: application to daily temperatures. PHYSICAL REVIEW E 62:(1) 150-160 (2000)

[88] Makan Gergely: Versenykajak mozgásának mérése és a mért jelalakok analízise, Diplomamunka, SZTE TTIK, Szeged, 2013.

[89] Vadai Gergely: Versenykajak mozgásának mérése és a mért jelek statisztikai elemzése, Diplomamunka, SZTE TTIK, Szeged, 2012.

[90] Kemecsei Imre: A kajak technika belső szerkezete, Budapest, 2004, Magyar Kajak-Kenu Szövetség.

[91] RV Mann, JT Kearney, A biomechanical analysis of the Olympic-style flatwater kayak stroke. MEDICINE AND SCIENCE IN SPORTS AND EXERCISE 12:(3) pp. 183-188 (1980)

[92] DA Aitken, RJ Neal, An on-water analysis system for quantifying stroke force characteristics during kayak events. INTERNATIONAL JOURNAL OF SPORT BIOMECHANICS 8:(2) pp. 165-173 (1992)

[93] M Begon, F Colloud, A kayak ergometer using a sliding trolley to reproduce accurate on-water mechanical conditions. In Proceedings of XXI congress of the International Society of Biomechanics Taipei, Taiwan, 2007.07.01-05, JOURNAL OF BIOMECHANICS 40:(S2) S439 (2007)

[94] DR Pendergast, D Bushnell, DW Wilson, P Cerretelli, Energetics of kayaking. EUROPEAN JOURNAL OF APPLIED PHYSIOLOGY AND OCCUPATIONAL PHYSIOLOGY 59:(5) pp. 342-350 (1989)

[95] N Fleming, B Donne, D Fletcher, N Mahony, A biomechanical assessment of ergometer task specificity in elite flatwater kayakers. JOURNAL OF SPORTS SCIENCE AND MEDICINE 11: pp. 16-25 (2012) 
[96] D Bishop, D Bonetti, B Dawson, The effect of three different warm-up intensities on kayak ergometer performance. MEDICINE AND SCIENCE IN SPORTS AND EXERCISE 33: pp. 1026-1032 (2001)

[97] D Bishop, D Bonetti, B Dawson, The influence of pacing strategy on VO2 and supramaximal kayak performance. MEDICINE AND SCIENCE IN SPORTS AND EXERCISE 34: pp. 1041-1047 (2002)

[98] P Zamparo, C Capelli, G Guerrini, Energetics of kayaking at submaximal and maximal speeds. EUROPEAN JOURNAL OF APPLIED PHYSIOLOGY AND OCCUPATIONAL PHYSIOLOGY 80:(6) pp. 542-548 (1999)

[99] K Sidney, RJ Shephard, Physiological characteristics and performance of the white-water paddler. EUROPEAN JOURNAL OF APPLIED PHYSIOLOGY AND OCCUPATIONAL PHYSIOLOGY 32:(1) pp. 55-70 (1973)

[100] KA von Someran, GR Phillips, GS Palmerm, Comparison of physiological responses to open water kayaking and kayak ergometry. INTERNATIONAL JOURNAL OF SPORTS MEDICINE 21:(3) pp. 200-204 (2000)

[101] KA von Someran, JE Oliver, The efficacy of ergometry determined heart rates for flatwater kayak training. INTERNATIONAL JOURNAL OF SPORTS MEDICINE 23:(1) pp. 28-32 (2001)

[102] ArguStress KayakPro mérőrendszer, gyártó: ArguScan Kft. http://www.argustress.com

[103] JP Stothart, FD Reardon, JS Thoden, System for the evaluation of on-water stroke force development during canoe and kayak events. In J Terauds, BA Gowitzke, LE. Holt (eds.): Proceedings of 4th International Symposium On Biomechanics In Sports, Halifax, Canada, 1986

[104] MG Robinson, LE Holt, TW Pelham, K Furneaux, Accelerometry Measurements of Sprint Kayaks: The Coaches' New Tool. INTERNATIONAL JOURNAL OF COACHING SCIENCE 5:(1) pp. 45-56 (2011)

[105] M Robinson, Olympic canoe-kayak performance analysis system: A coaches tool. Presented to the School of Kinesiology, University of Calgary, Calgary, Alberta. (2006)

[106] Z Ma, J Zhang, Y Sun, T Mei, Sports Biomechanical Information Acquisition and Evaluation for Kayaking Events. INTERNATIONAL JOURNAL OF INFORMATION ACQUISITION 6:(3) pp. 213-223 (2009)

[107] I Janssen, A Sachlikidis, Validity and reliability of intra-stroke kayak velocity and acceleration using a GPS-based accelerometer. SPORT BIOMECHANICS 9:(1) pp. 47-56 (2010) 
[108] AGW Carter, JP Peach, TW Pelham, LE Holt, Discrete measures of C1 craft acceleration using various paddle designs. In A Barabás, Gy. Fábián (eds.): Proceedings of 4th International Symposium On Biomechanics In Sports, Budapest-Siófok, Hungary, 1994.07.02-06. pp. 190-193.

[109] B Gomes, N Viriato, R Sanders, F Conceição, JP Vilas-Boas, M Vaz, Analysis of the on-water paddling force profile of an elite kayaker. In P Vilas-Boas et al (eds.): Proceedings of 29th International Symposium On Biomechanics In Sports, Porto, Portugal, 2011.06.27.-2011.07.01. pp. 259-262.

[110] RH Sanders, JS Kendal, A description of Olympic Flatwater Kayak Stroke Technique. AUSTRALIAN JOURNAL OF SCIENCE AND MEDICINE IN SPORT 24:(1) pp. 25-30 (1992)

[111] JS Michael, R Smith, KB Rooney, Determinants of kayak paddling performance. SPORTS BIOMECHANICS 8:(2) pp. 167-179 (2009)

[112] C López López, J Ribas Serna, Quantitative analysis of kayak paddling technique: definition of an optimal stroke profile. REVISTAANDALUZADE MEDICINA DEL DEPORTE 4:(3) pp. 91-95 (2011)

[113] J Baker, D Rath, R Sanders, B Kelly, A three-dimensional analysis of male and female elite sprint kayak paddlers. In RH Sanders, BJ Gibson (Eds.): Proceedings Of 17th International Symposium Biomechanics In Sports, Perth, Australia, 1999.06.30.-1999.07.06. pp. 53-56.

[114] Gerber Balázs: Kajakozási technika komplex elemzése gyoruslásmérés segítségével. TDK dolgozat, Pázmány Péter Katolikus Egyetem Információs Technológiai Kar, Budapest, 2007.

[115] Margi Bohm: New 'Smart Paddle' May Revolutionize Training, Canoe and Kayak Racing. Online: http://issuu.com/ckrmagazine/docs/july-aug_2010 (2010)

[116] DigiTrainer mérőrendszer, gyártó: Polaritás Ltd. http://paddles.bracasport.com/accessories/digitrainer.html

[117] Minimax B4 mérőrendszer, gyártó: Catapult, https://performbetter.co.uk/

[118] M Brennan, M Palaniswami, P Kamen, Do existing meausures of Poincare plot geometry reflect nonliear features of heart rate variability? IEEE TRANSACTIONS ON BIOMEDICAL ENGINEERING 48:(11) pp. 1342-1347 (2001)

[119] X Copie, JY Ie Heuzey, MC Iliou, R Khouri, T Lavergne, F Pousset, L Guize, Correlation between time-domain measures of heart rate variability and scatterplots in postinfarction patients. PACING AND CLINICAL ELECTROPHYSIOLOGY 19:(3) pp. 342-347 (1996) 